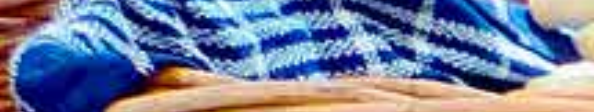

DW. $=2, j \mid$

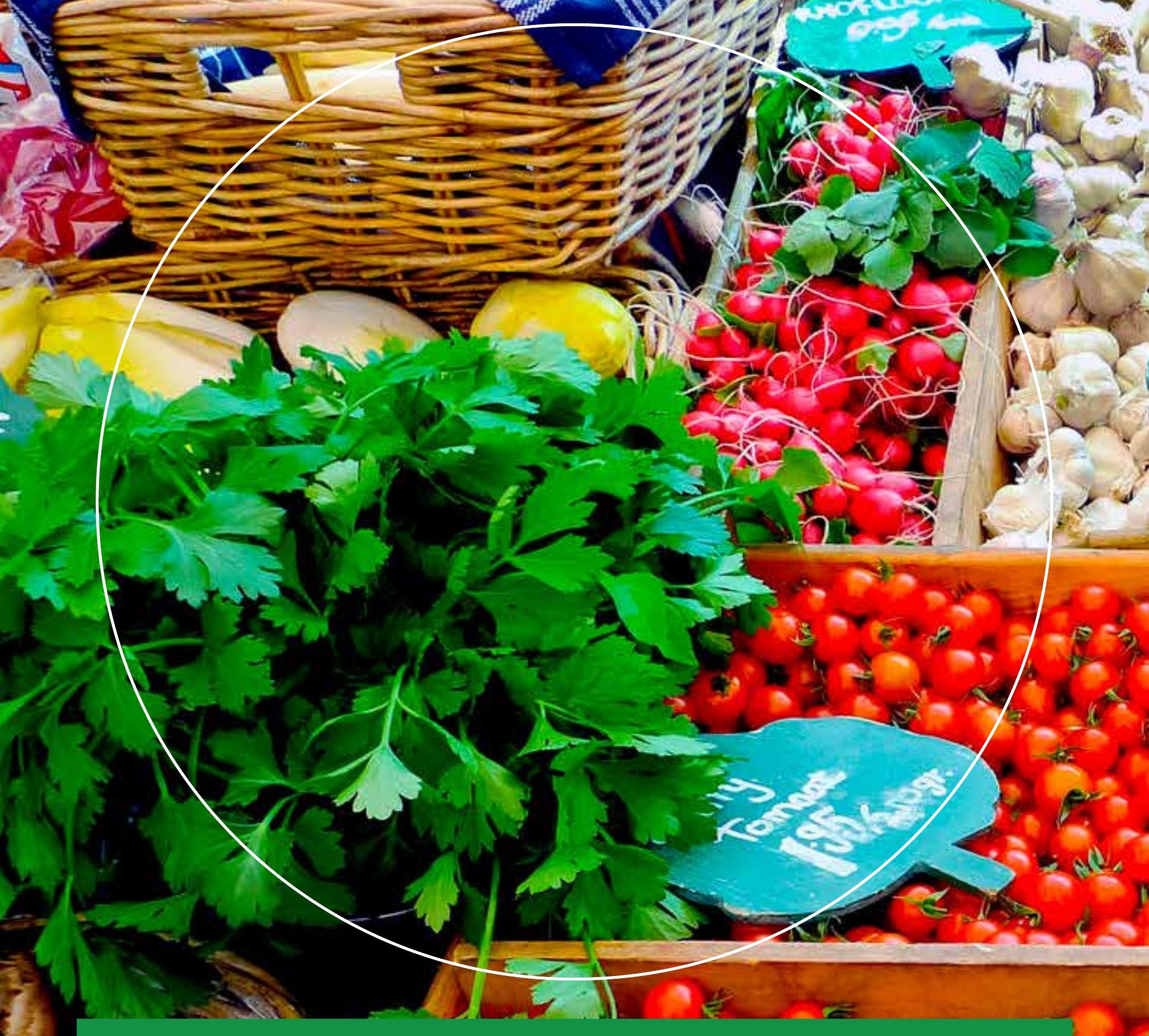

\title{
Staat van Landbouw en Voedsel
}

Editie 2021

Petra Berkhout, Harold van der Meulen, Pascal Ramaekers 


\section{Staat van Landbouw en Voedsel}

Editie 2021

Petra Berkhout ${ }^{1}$, Harold van der Meulen ${ }^{1}$, Pascal Ramaekers ${ }^{2}$

1 Wageningen Economic Research

2 CBS

Dit onderzoek is uitgevoerd door Wageningen Economic Research en het Centraal Bureau voor de Statistiek op verzoek van en gesubsidieerd door het ministerie van Landbouw, Natuur en Voedselkwaliteit, in het kader van het Beleidsondersteunend onderzoeksthema 'Economie' (projectnummer BO-43-115-009).

Wageningen Economic Research

Wageningen, januari 2022

RAPPORT

2022-013

ISBN 978-94-6447-064-2 
Petra Berkhout, Harold van der Meulen, Pascal Ramaekers, 2022. Staat van Landbouw en Voedsel; Editie 2021. Wageningen/Heerlen/Den haag, Wageningen Economic Research en Centraal Bureau voor de Statistiek, Rapport 2022-013. 164 blz.; 72 fig.; 23 tab.; 220 ref.

Deze publicatie geeft een breed overzicht van de stand van zaken in de Nederlandse agrosector. Er wordt ingegaan op onder meer economische indicatoren als toegevoegde waarde en werkgelegenheid, de ketenstructuur van verschillende producten, buitenlandse handel, verkoopkanalen en consumptie van voeding, structuurkenmerken van bedrijven in de gehele agroketen, inkomensontwikkelingen, bedrijvendynamiek in de keten, innovatie, de milieu-impact van landbouwproductie, evenals de bijdrage van de landbouw aan de duurzaamheidsdoelen van de Verenigde Naties (SDG's).

This publication provides a broad overview of the situation of the Dutch agribusiness sector. It discusses, among other things, economic indicators such as value added and employment, the chain structure of various products, foreign trade, sales channels and consumption of food, structural characteristics of businesses throughout the agro chain, income developments, business dynamics in the chain, innovation, the environmental impact of agricultural production, as well as the contribution of the agricultural sector to the UN Sustainable Development Goals (SDGs).

Trefwoorden: agrosector, landbouw, structuur, inkomen, milieu, voeding

Dit rapport is gratis te downloaden op https://doi.org/10.18174/560517 of op www.wur.nl/economicresearch (onder Wageningen Economic Research publicaties).

(C) 2022 Wageningen Economic Research

Postbus 29703, 2502 LS Den Haag, T 07033583 30, E communications.ssg@wur.nl, www.wur.nl/economic-research. Wageningen Economic Research is onderdeel van Wageningen University \& Research.

\section{(cc) BY-NC}

Dit werk valt onder een Creative Commons Naamsvermelding-Niet Commercieel 4.0 Internationaal-licentie.

(C) Wageningen Economic Research, onderdeel van Stichting Wageningen Research, 2022

De gebruiker mag het werk kopiëren, verspreiden en doorgeven en afgeleide werken maken. Materiaal van derden waarvan in het werk gebruik is gemaakt en waarop intellectuele eigendomsrechten berusten, mogen niet zonder voorafgaande toestemming van derden gebruikt worden. De gebruiker dient bij het werk de door de maker of de licentiegever aangegeven naam te vermelden, maar niet zodanig dat de indruk gewekt wordt dat zij daarmee instemmen met het werk van de gebruiker of het gebruik van het werk. De gebruiker mag het werk niet voor commerciële doeleinden gebruiken.

Wageningen Economic Research aanvaardt geen aansprakelijkheid voor eventuele schade voortvloeiend uit het gebruik van de resultaten van dit onderzoek of de toepassing van de adviezen.

Wageningen Economic Research is ISO 9001:2015 gecertificeerd.

Wageningen Economic Research Rapport 2022-013 | Projectcode 2282200625

Foto omslag: Shutterstock 


\section{Inhoud}

Woord vooraf

1.1 Aanleiding

1.2 Aanpak, opbouw rapport

$2.1 \quad$ Inleiding

2.2 Agrocomplex

2.2.1 Algemeen

2.2.2 Ontwikkeling agrocomplex op langere termijn

2.2.3 Levensmiddelenindustrie

2.3 Ketens in beeld

2.3.1 Inleiding

2.3.2 Granen

2.3.3 Suiker

2.3.4 Aardappelen

2.3.5 Groente- en fruit

2.3.6 Varkens

2.3.7 Pluimvee

2.3.8 Eieren

2.3.9 Zuivel

2.3.10Kalveren

2.3.11 Sierteelt

2.4 Buitenlandse handel

2.5 Verdiensten in binnen- en buitenland

$\begin{array}{lll}3.1 & \text { Inleiding } & 54\end{array}$

$\begin{array}{lll}3.2 & \text { Verkoopkanalen voedsel } & 54\end{array}$

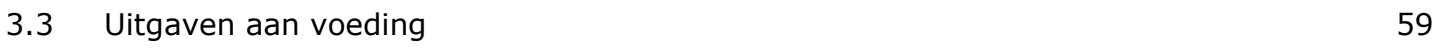

$\begin{array}{ll}3.3 .1 \text { Algemeen } & 59\end{array}$

3.3.2 Uitgaven aan voedsel met duurzaamheidskeurmerk $\quad 60$

$\begin{array}{ll}\text { 3.3.3 Omzet biologisch voedsel } & 62\end{array}$

$\begin{array}{ll}3.3 .4 \text { Voedselprijzen } & 63\end{array}$

$\begin{array}{lll}3.4 & \text { Voedselverspilling } & 63\end{array}$

3.5 Dierenwelzijn in de markt - speciaal onderwerp 65

$\begin{array}{llr}4.1 & \text { Inleiding } & 69\end{array}$

$\begin{array}{llr}4.2 & 69\end{array}$

$\begin{array}{ll}\text { 4.2.1 Aantal bedrijven } & 69\end{array}$

$\begin{array}{ll}4.2 .2 \text { Grond } & 71\end{array}$

$\begin{array}{ll}4.2 .3 \text { Arbeid } & 74\end{array}$

$\begin{array}{ll}4.2 .4 \text { Kapitaal } & 76\end{array}$

$\begin{array}{ll}4.2 .5 \text { Veestapel } & 80\end{array}$

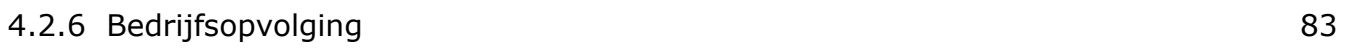


$\begin{array}{ll}\text { 4.2.7 Duurzame investeringen } & 87\end{array}$

$\begin{array}{ll}4.2 .8 & \text { Innovatie }\end{array}$

$\begin{array}{llr}4.3 & \text { Ruimtelijke verdeling } & 89\end{array}$

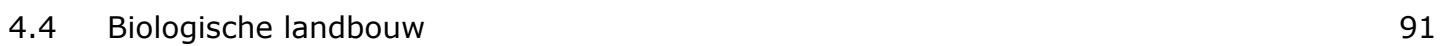

\begin{tabular}{ll}
4.5 & Multifunctionele landbouw \\
\hline
\end{tabular}

$\begin{array}{ll}4.6 & 95\end{array}$

$\begin{array}{ll}\text { 4.6.1 Sectorresultaten } & 95\end{array}$

4.6.2 Sectorresultaten in EU-27 96

4.6.3 Inkomensvorming op bedrijfsniveau 98

$\begin{array}{ll}\text { 4.6.4 Bedrijven met lage inkomens } & 101\end{array}$

$\begin{array}{lll}4.7 & \text { Dilemma's hervorming pachtstelsel } & 104\end{array}$

5

$\begin{array}{ll}\text { Overige agribusiness } & 107\end{array}$

$\begin{array}{llr}5.1 & \text { Inleiding } & 107\end{array}$

$\begin{array}{llr}5.2 & \text { Achtergrond } & 107\end{array}$

$\begin{array}{llr}5.3 & \text { Bedrijvendynamiek en werkgelegenheid } & 109\end{array}$

$\begin{array}{llr}5.4 & \text { Innovatie in de Nederlandse agribusiness } & 117\end{array}$

5.5 R\&D in de Nederlandse agribusiness door de tijd $\quad 119$

5.6 Investeringen in materiële vaste activa $\quad 121$

6

$\begin{array}{lr}\text { Leefomgeving } & 123\end{array}$

$\begin{array}{llr}6.1 & \text { Inleiding } & 123\end{array}$

$\begin{array}{lll}6.2 & \text { Economische en ecologische prestaties } & 123\end{array}$

$\begin{array}{ll}6.2 .1 \text { Algemeen } & 123\end{array}$

6.2.2 Langetermijntrends $\quad 124$

6.2.3 Bijdragen aan Sustainable Development Goals $\quad 125$

$\begin{array}{ll}6.3 & \text { Gewasbescherming en plantgezondheid } \\ \end{array}$

$\begin{array}{ll}6.3 .1 \text { Verbruik en milieubelasting } & 128\end{array}$

$\begin{array}{lr}6.3 .2 \text { Plantgezondheid } & 129\end{array}$

$\begin{array}{llr}6.4 & \text { Broeikasgasemissies } & 130\end{array}$

6.4.1 Glastuinbouw 131

$\begin{array}{llr}6.5 & \text { Fijnstof } & 132\end{array}$

$\begin{array}{llr}6.6 & \text { Fosfaat- en stikstofproductie } & 133\end{array}$

$\begin{array}{lll}6.6 .1 & \text { Fosfaat } & 134\end{array}$

$\begin{array}{ll}6.6 .2 \text { Stikstof } & 135\end{array}$

6.7 Ammoniak 136

$\begin{array}{llr}6.8 & \text { Dierenwelzijn en diergezondheid } & 137\end{array}$

$\begin{array}{ll}\text { 6.8.1 Dierenwelzijn } & 137\end{array}$

6.8.2 Diergezondheid 139

6.9 Agrarisch natuurbeheer en biodiversiteit $\quad 141$

6.9.1 Inleiding $\quad 141$

6.9.2 Agrarisch natuurbeheer in Nederland 143

6.9.3 Natuurinclusieve landbouw $\quad 145$

6.9.4 Conclusies en vooruitblik 146

$\begin{array}{lr}\text { Bronnen en literatuur } & 147\end{array}$

$\begin{array}{llr}\text { Bijlage } 1 & \text { Projectleiding en auteurs } & 160\end{array}$

Bijlage 2 Indicatoren LNV-begroting $r$

$\begin{array}{lll}\text { Bijlage } 3 & \text { Definitie agribusiness } & 163\end{array}$ 


\section{Woord vooraf}

Er is veel informatie beschikbaar over de Nederlandse agrosector en over de voedselconsumptie van de Nederlandse consument. Het gaat dan onder andere om gegevens over structuurontwikkelingen, inkomens in de primaire landbouw, milieuaspecten, innovatie, uitgaven aan en verkoopkanalen van voedsel. Deze informatie is nu te vinden op uiteenlopende websites en in verschillende publicaties. Bij het ministerie van Landbouw, Natuur en Voedselkwaliteit is er behoefte de beschikbare informatie meer in onderlinge samenhang te publiceren in een zogenaamde Staat van Landbouw en Voedsel. Deze publicatie is hiervan het resultaat en brengt de informatie die op verschillende plekken staat bij elkaar, voorzien van 'kop en staart'.

Deze eerste uitgave is een overgangsrapportage, waarin de reikwijdte van het rapport zich beperkt tot de agrarische sector en de voedselconsumptie. Het is de bedoeling deze reikwijdte in 2022 te verbreden naar een groter aantal LNV-thema's, met mogelijk ook informatie uit andere bronnen dan van Wageningen Economic Research en CBS.

Deze publicatie is tot stand gekomen dankzij het werk van vele auteurs. De concept-publicatie is door verschillende mensen binnen en buiten de betrokken organisaties gelezen en van commentaar voorzien. We danken iedereen hartelijk voor hun inzet.

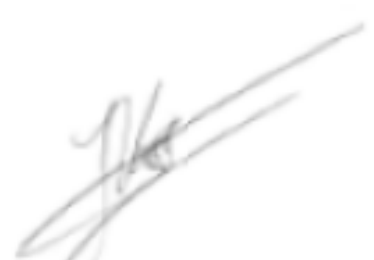

Prof.dr.ir. J.G.A.J. (Jack) van der Vorst Algemeen Directeur Social Sciences Group (SSG) Wageningen University \& Research

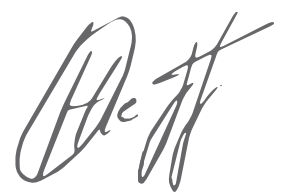

Ir. O. (Olaf) Hietbrink

Business Unit Manager Wageningen Economic Research Wageningen University \& Research 


\section{Samenvatting}

De Nederlandse agrosector

De toegevoegde waarde van het totale agrocomplex bedroeg in 2019 circa 56 mld. euro: dat is circa $7 \%$ van het BNP. De bijdrage aan de werkgelegenheid ligt rond de $8 \%$. Het relatieve aandeel van het complex op basis van buitenlandse grondstoffen neemt toe; Nederland wordt steeds meer een land dat waarde toevoegt aan buitenlandse grondstoffen (paragraaf 2.2).

Jaarlijks brengt Wageningen Economic Research 10 onderscheiden ketens in de Nederlandse land- en tuinbouw in meer detail in beeld. In 2020 zijn de ketens voor de sectoren varkens, pluimvee, eieren en zuivel bijgewerkt. In 2021 zijn de ketens voor granen, suikerbieten, aardappelen, groente en fruit, sierteelt en vleeskalveren geactualiseerd (paragraaf 2.3).

Nederland is ook in 2020, in waarde gemeten, tweede exporteur van landbouwgoederen (inclusief wederuitvoer) in de wereld na de Verenigde Staten van Amerika. Verdeeld naar werelddeel gaat er in 2020 ruim 81\% naar Europa, ruim 10\% naar Azië, 5\% naar Amerika en 3\% naar Afrika. In de afgelopen 20 jaar is het aandeel naar Azië gegroeid van 7 naar 10\% (paragraaf 2.4).

In 2020 was $60 \%$ van de totale verdiensten aan de afzet van landbouwgoederen ( 71 mld. euro) te danken aan export en $40 \%$ aan binnenlandse afzet. In 2019 was het exportaandeel nog 62,6\%. In het coronajaar 2020 heeft de export het lastig gehad om door te groeien, terwijl de focus op lokale verkoop groter is geworden (paragraaf 2.5).

\section{Voedselconsumptie}

Supermarkten zijn het belangrijkste afzetkanaal van voedsel. In 2019 werd ongeveer 53\% van de ongeveer 65 mld. euro uitgaven aan voedsel in supermarkten besteed. Het tweede belangrijke kanaal was de foodservice met ongeveer 32\% van alle bestedingen aan voedsel in 2019. De corona-pandemie zorgt voor een vraagverschuiving naar de detailhandel en voor een boost in online verkoop van voeding (paragraaf 3.2).

In 2020 was het aandeel van de uitgaven aan voedsel met een duurzaamheidskeurmerk met onafhankelijke controle in de supermarkten, de foodservice en gespecialiseerde winkels in duurzamer voedsel $16 \%$ (paragraaf 3.3). Daarbinnen heeft het Beter Leven keurmerk met 34\% het grootste aandeel, gevolgd door Biologisch (18\%) en UTZ Certified (16\%). In 2020 zijn de bestedingen aan biologisch voedsel licht afgenomen met $1 \%$ door het wegvallen van de afzet in de foodservice (paragraaf 3.3 ).

De voedselverspilling bedroeg in 2018 per hoofd van de bevolking tussen de 96 en 149 kilogram. Sinds 2018 zijn er verschillende stappen gezet om voedselverspilling tegen te gaan. Het is echter nog niet goed mogelijk om het effect hiervan in de cijfers te zien vanwege de bandbreedte in de cijfers over voedselverspilling (paragraaf 3.4).

Twaalf jaar marktontwikkeling voor dierenwelzijn laat zien dat er een beweging gemaakt is richting diervriendelijkere producten in de supermarkt. De vraag van de Nederlandse consument is maar beperkt aanjager geweest voor een beter dierenwelzijn (paragraaf 3.5).

Land- en tuinbouw

Het aantal land- en tuinbouwbedrijven is volgens de landbouwtelling in 2020 met ruim 500 afgenomen tot 52.700 , een daling met $1,0 \%$. Dat is ruim onder het langjarige gemiddelde van bijna $3 \%$ per jaar tussen 2000 en 2015 (paragraaf 4.2.1). 
Het areaal cultuurgrond in gebruik bij de geregistreerde land- en tuinbouwbedrijven is in 2020 uitgekomen op 1,814 mln. ha. Tussen 2000 en 2020 is het areaal met gemiddeld 0,4\% per jaar verminderd (paragraaf 4.2.2).

Het arbeidsvolume in de land- en tuinbouw is in 2020 met $1 \%$ gestegen tot 157.700 arbeidsjaareenheden, een maat die binnen de land- en tuinbouw gebruikt wordt voor het aantal voltijdbanen. Vanaf de eeuwwisseling tot 2018 is het arbeidsvolume met gemiddeld $2 \%$ per jaar gedaald (paragraaf 4.2.3).

De gemiddelde balanswaarde per einde boekjaar van de land- en tuinbouwbedrijven was in 2019 ruim $3,5 \mathrm{mln}$. euro; een stijging van 700.000 euro ten opzichte van 2015 . Het aandeel van de grond op de balans bedraagt meer dan 50\% (paragraaf 4.2.4).

Het aantal melkkoeien is in 2020 heel licht gestegen, evenals het totaal aantal kippen. Het totaal aantal varkens is gedaald, evenals het totaal aantal overige graasdieren (paragraaf 4.2.5).

Het aantal land- en tuinbouwbedrijven met een bedrijfshoofd ouder dan 50 jaar is tussen 2012 en 2020 met tien procentpunten gestegen tot $71 \%$. In 2020 is op $40 \%$ van de 34.100 bedrijven met een bedrijfshoofd ouder dan 50 jaar, een opvolger aanwezig (paragraaf 4.2.6).

Het aandeel duurzame investeringen in 2019 komt uit op 17\%: dit is een lichte stijging van $1 \%$ ten opzichte van 2018 en ligt onder het gemiddelde in dit decennium van 27\% (paragraaf 4.2.7).

Het aandeel innovatoren in de primaire land- en tuinbouw ligt in de periode 2013-2019 onder de $2 \%$. Het aandeel koplopers schommelt, met een maximaal aandeel van $11 \%$ van de bedrijven in 2015 (paragraaf 4.2.8).

Er zijn grote verschillen in de economische intensiteit (gemeten in Standaardopbrengst (SO)) van de landen tuinbouw tussen regio's, die ook ruimtelijk goed zijn weer te geven (paragraaf 4.3).

Het aantal gecertificeerde biologische land- en tuinbouwbedrijven is in Nederland in 2020 ten opzichte van 2019 met $3 \%$ toegenomen tot 2.019 ; in 2019 was de toename nog $6 \%$ ten opzichte van 2018 . Het gecertificeerde areaal steeg in 2020 met 7\% tot 74.282 ha (paragraaf 4.4).

In 2020 waren er ruim 22.000 agrarische bedrijven met een of meer verbredingsactiviteiten; $42 \%$ van het totale aantal bedrijven. Dit aandeel ligt hoger dan in voorgaande metingen; in 2010 bedroeg het aandeel nog $28 \%$ (paragraaf 4.5 ).

\section{Overige agribusiness}

In totaal waren er in 202045 duizend bedrijven actief in de 'overige agribusiness', 5\% meer dan in 2016. Drie van de vier bedrijven in de overige agribusiness behoort tot de groothandel of detailhandel (supermarkt, winkels of markthandel). Het betreft wel voor het overgrote deel (89\%) bedrijven met minder dan 10 werkzame personen (paragraaf 5.3).

Voor de gehele agribusiness (inclusief primaire landbouw) geldt dat bijna 30\% van de bedrijven met tien of meer werkzame personen zich in de periode 2016-2018 op de een of andere manier bezighield met innovatie (paragraaf 5.4).

In 2019 spendeerde de agribusiness voor het eerst meer dan een miljard aan R\&D. De ontwikkeling van de uitgaven aan R\&D van de agribusiness is over de tijd stabieler dan die van alle bedrijven samen, de R\&Dintensiteit fluctueert minder dan bij alle bedrijven. Het aandeel van de agribusiness in de totale R\&Duitgaven kwam in 2019 uit op 9,2\%(paragraaf 5.5).

In de periode 2013-2019 zijn de investeringen van de overige agribusiness in materiële vaste activa opgelopen van 46 mld. euro in 2013 tot ruim 65 mld. euro in 2019 (paragraaf 5.6). 


\section{Leefomgeving}

De landbouwsector heeft sinds 1995 sterke vooruitgang geboekt op duurzaamheidsgebied, maar de meeste verduurzaming heeft daarbij wel in de jaren negentig en het eerste decennium van de $21^{\text {ste }}$ eeuw plaatsgevonden. Er zijn steeds meer instrumenten om de Nederlandse prestaties door de tijd en internationaal te monitoren, waaronder sinds kort de natuurlijk kapitaalrekeningen (paragraaf 6.2).

De afzet van gewasbeschermingsmiddelen schommelde tot 2018 lange tijd rond de $10 \mathrm{mln}$. kilo actieve stof per jaar. In 2018 zakte de afzet onder de $10 \mathrm{mln}$. kilo. In 2019 lag de afzet vrijwel op hetzelfde niveau als in 2018 (paragraaf 6.3).

De broeikasgasemissie uit de land- en tuinbouw was in 2019 26,5 Mton $\mathrm{CO}_{2}$-equivalenten: 0,2 Mton $\mathrm{CO}_{2}$ equivalenten lager dan in 2018. De broeikasgasemissie uit de land- en tuinbouw is ten opzichte van 1990 met $18 \%$ gedaald (paragraaf 6.4 ).

Van de fijnstofemissie (PM10) in Nederland is 18\% in 2019 afkomstig uit de land- en tuinbouw. Van de fijnstofemissie uit de landbouw is 62\% afkomstig uit de pluimveehouderij (paragraaf 6.5).

De hoeveelheid fosfaat in dierlijke mest is in 2020 ruim $22 \mathrm{mln}$. kg lager dan het door de Europese Unie vastgestelde productieplafond. De stikstofproductie in zowel 2019 als 2020 was met bijna $490 \mathrm{mln}$. kg enkele procenten lager dan het EU-productieplafond (paragraaf 6.6).

De ammoniakemissie in de landbouw was in 2019 met bijna $106 \mathrm{mln}$. kg 5\% lager dan in 2018. Tussen 1990 en 2000 is de ammoniakemissie meer dan gehalveerd tot circa $155 \mathrm{mln}$. kg NH (paragraaf 6.7).

Het dierenwelzijn in de Nederlandse veehouderij staat al jaren in de maatschappelijke belangstelling. Het gaat vooral om de vraag in hoeverre dieren hun natuurlijke gedrag kunnen vertonen en om het uitbannen van lichamelijke ingrepen. Momenteel zijn diverse lichamelijke ingrepen nog toegestaan, onder voorwaarden (paragraaf 6.8).

Om het gewenste behoud van agrarische biodiversiteit te realiseren, is een brede aanpak noodzakelijk. Met een passend verdienmodel kunnen economie en natuurinclusiviteit, inclusief agrarisch natuurbeheer, elkaar versterken. Natuurinclusieve landbouw is op die manier van groot belang voor de toekomst van de landbouw (paragraaf 6.9).

\section{Methodologie}

De informatie in deze Staat van de Landbouw is gebaseerd op data- en literatuuronderzoek. Voor veel van de onderwerpen gaat het om bijdragen die volgen uit lopend onderzoek en/of lopende monitoring van ontwikkelingen op het gebied van landbouw en voedsel. 


\section{Summary}

The Dutch agriculture sector

In 2019 the added value of the entire agriculture complex amounted to around 56bn euros, or around 7\% of GDP. It accounted for around $8 \%$ of employment. The complex is increasingly underpinned by raw materials sourced from overseas: in other words, the Netherlands is increasingly becoming a country that adds value to imported raw materials (section 2.2).

Every year, Wageningen Economic Research publishes a detailed analysis of 10 different supply chains in the Dutch agricultural and horticultural sectors. In 2020 the analyses looked at the supply chains for the pig, poultry, egg and dairy sectors. The 2021 updates have focused on the supply chains for grains, sugar beet, potatoes, fruits and vegetables, floriculture and veal (section 2.3).

In 2020 the Netherlands was also the world's second-largest exporter, by value, of agricultural goods (including re-exports) after the United States of America. In continental terms, just over $81 \%$ of these exports went to Europe in 2020, with over 10\% going to Asia, 5\% to America and 3\% to Africa. Over the past 20 years the share of exports destined for Asia has grown from 7\% to 10\% (section 2.4).

In 2020, $60 \%$ of total earnings from the sale of agricultural products ( $71 \mathrm{bn}$ euros) was attributed to exports, with $40 \%$ coming from domestic sales. In 2019 the share attributed to exports was a bit higher, at $62.6 \%$. The coronavirus made 2020 a difficult year for export growth, while local sales became more of a focal point (section 2.5).

\section{Food consumption}

Supermarkets are the key sales channel for food. In 2019 around 65bn euros was spent on food, and supermarkets accounted for about $53 \%$ of that. The second most important sales channel was the food service sector, accounting for around $32 \%$ of all food expenditure in 2019 . The coronavirus pandemic led to a shift in demand towards the retail sector and to a boost in online food sales (section 3.2).

In 2020 , foods certified through an independent sustainability quality label scheme accounted for $16 \%$ of food sales across supermarkets, the food service sector and shops that specialise in more sustainable products (section 3.3). The Beter Leven ('Better Life') quality label accounted for the largest proportion (34\%) of those sales, followed by Biologisch (organic) with $18 \%$ and UTZ Certified with $16 \%$. There was a slight $(1 \%)$ decline in spending on organic food in 2020 , which can be attributed to the drop in sales within the food service sector (section 3.3).

Per capita food waste ranged from $96 \mathrm{~kg}$ to $149 \mathrm{~kg}$ in 2018 . Since then, a number of measures have been introduced to reduce food waste. However, the impact of those measures is not yet clearly discernible in the current data due to the broad scope of food waste figures (section 3.4).

Twelve years of market development in the realm of animal welfare has driven a move towards higherwelfare products in supermarkets. However, consumer demand in the Netherlands has only played a limited role in accelerating these improvements (section 3.5).

\section{Agriculture and horticulture}

According to the agricultural census, the number of agricultural and horticultural businesses declined in 2020 by more than 500 to 52,700 , a drop of $1.0 \%$. That's significantly less than the long-term average of almost $3 \%$ per year from 2000 to 2015 (section 4.2.1).

The amount of farmland used by registered agricultural and horticultural businesses in 2020 came to 1.814 million hectares. From 2000 to 2020 this farmland declined by an average of $0.4 \%$ per year (section 4.2.2). 
The total labour force within the agricultural and horticultural sector increased by $1 \%$ in 2020 to 157,700 annual work units, which is the measure of the total number of full-time jobs in the sector. From 2000 to 2018 the labour force has decreased by an average of $2 \%$ per year (section 4.2 .3 ).

The average balance sheet value at the end of the financial year for agricultural and horticultural businesses was more than 3.5 million euros in 2019, an increase of 700,000 euros compared to 2015. Land accounted for more than $50 \%$ of the balance sheet (section 4.2 .4 ).

The number of dairy cows grew slightly in 2020, as did the total number of chickens. There was a decline in the total number of pigs, and the total number of other grazing animals dropped too (section 4.2.5).

The number of agricultural and horticultural businesses led by someone over the age of 50 increased by 10 percentage points between 2012 and 2020, to 71\%. In 2020, 40\% of the 34,100 businesses led by someone over the age of 50 had an allocated successor in place (section 4.2.6).

Sustainable investments had a $17 \%$ share in 2019: this is a slight increase of $1 \%$ compared to 2018 and is less than the $27 \%$ average across the decade (section 4.2 .7 ).

Innovators made up less than 2\% of the primary agriculture and horticulture sector for 2013 to 2019 . The proportion of trailblazers in the sector has fluctuated, reaching a maximum of $11 \%$ of businesses in 2015 (section 4.2.8).

There are significant differences in the economic intensity (measured in Standard Output (SO)) of agricultural and horticultural businesses across different regions, and these differences are clearly discernible in a spatial representation (section 4.3).

The number of certified organic agricultural and horticultural businesses grew by 3\% from 2019 to 2020 to reach 2,019 . In 2019 , that increase was $6 \%$ compared to 2018 . The amount of land under certification grew by $7 \%$ in 2020 to reach 74,282 ha (section 4.4 ).

In 2020 more than 22,000 agricultural businesses, or $42 \%$ of the total, had diversified into at least one additional income stream. This proportion has grown over time: in 2010 , it was still only $28 \%$ (section 4.5 ).

\section{Other agribusiness}

A total of 45,000 businesses were active in the 'other agribusiness' sector in 2020,5\% more than in 2016. Three out of four businesses in the 'other agribusiness' sector are wholesalers or retailers (supermarkets, shops or suppliers). Most of these (89\%) are businesses with fewer than 10 employees (section 5.3).

For the agribusiness sector as a whole (including primary agriculture) almost $30 \%$ of businesses with 10 or more employees engaged in innovative practices in some form during 2016-2018 (section 5.4).

2019 was the first year that agribusinesses spent more than a billion euros on R\&D. Agribusinesses have developed their R\&D spend more steadily compared to the agricultural sector as a whole, with fewer fluctuations in the level of their R\&D. Agribusinesses accounted for 9.2\% of total R\&D spend in 2019 (section 5.5).

From 2013-2019 investments in the 'other agribusiness' sector into tangible assets grew from 46bn euros in 2013 to more than 65bn euros in 2019 (section 5.6).

\section{Living environment}

The agriculture sector has made great strides in sustainability since 1995, but most of those sustainability improvements took place in the 1990s and the first decade of the 21st century. There's a growing array of instruments for monitoring sustainability progress in the Netherlands, with one of the latest being natural capital accounts (section 6.2). 
Until 2018, sales of crop protection agents had hovered for a long time at around 10 million kilos of active ingredients per year. In 2018 sales dropped below 10 million kilos. In 2019 sales were at virtually the same level as 2018 (section 6.3).

In 2019, greenhouse gas emissions from the agricultural and horticultural sectors amounted to 26.5 Mton $\mathrm{CO}_{2}$ equivalent, which is 0.2 Mton $\mathrm{CO}_{2}$ equivalent less than in 2018. Compared to 1990 , greenhouse gas emissions from the agricultural and horticultural sectors have decreased by $18 \%$ (section 6.4 ).

In $2019,18 \%$ of particulate matter emissions (PM10) in the Netherlands was attributable to the agricultural and horticultural sectors. The poultry sector accounts for $62 \%$ of particulate matter emissions in agriculture (section 6.5).

The amount of phosphate in animal manure in 2020 was more than 22 million kilos under the production ceiling set by the European Union. Nitrogen production, at almost 490 million kilos in both 2019 and 2020 , was several percentage points under the EU production ceiling (section 6.6).

Ammonia emissions in agriculture were almost 106 million kilos in 2019, 5\% less than in 2018. From 1990 to 2000 ammonia emissions dropped by more than half to around 155 million $\mathrm{kg} \mathrm{NH}_{3}$ (section 6.7).

Animal welfare in the Dutch livestock sector has been an important social issue for many years. This mainly manifests itself in the extent to which animals can express their natural behaviour and in the banning of mutilations. At present some mutilations are still permitted, under certain conditions (section 6.8).

The successful maintenance of agricultural biodiversity requires a comprehensive approach. Appropriate revenue models can create positive feedback loops between economics and environmental inclusiveness, including agricultural nature management. This means that nature-inclusive agriculture is crucial to the future of agriculture (section 6.9).

\section{Methodology}

The information in this State of the Agriculture Sector is based on data and literature research. Many of the topics covered are based on contributions drawn from on-going research and/or the on-going monitoring of developments in agriculture and food. 


\section{$1 \quad$ Inleiding}

\section{$1.1 \quad$ Aanleiding}

Het ministerie van Landbouw, Natuurbeheer en Voedselkwaliteit (LNV) heeft doorlopend behoefte aan informatie over ontwikkelingen in structuur, economische betekenis, handel met het buitenland en milieuprestaties van de gehele agroketen. Het gaat om informatie die nodig is voor een belangrijk primair proces van het ministerie, namelijk de interactie met de Tweede Kamer. De informatie is ook nodig voor de monitoring en verantwoording van (delen van) het LNV-beleid. De informatie dient daarbij duidelijk uitgelegd te worden en de betekenis ervan dient te worden toegelicht en van context voorzien. Ook voor het grotere publiek kan zo meer inzicht gegeven worden in het reilen en zeilen van de agroketen.

Voor de periode 2017-2020 was veel van de benodigde informatie voorhanden, maar via verschillende publicaties. Het gaat zowel om het Voedsel-Economisch Bericht (VEB), de publicatie over de internationale handelspositie van het agrocomplex en de publicatie Inkomen en Milieu, als om de meer bescheiden publicaties rondom de agrovertrouwensindex, de market outlook en de liquiditeitsmonitor.

\section{Naar een Staat van Landbouw en Voedsel}

Bij het ministerie bestaat de behoefte de informatie over de agrosector en de voedselconsumptie die nu op diverse plekken aanwezig is, meer in onderlinge samenhang te publiceren in een zogenaamde Staat van Landbouw en Voedsel. Deze publicatie is hiervan het resultaat, waarbij de informatie die op verschillende plekken staat bij elkaar is gebracht en van 'kop en staart' is voorzien. Daarbij is voortgebouwd op de eerdergenoemde publicaties.

Deze eerste uitgave is een overgangsrapportage, waarin de reikwijdte van het rapport zich beperkt tot de agrarische sector en de voedselconsumptie. Het is de bedoeling deze reikwijdte in 2022 te verbreden naar een groter aantal LNV-thema's, met mogelijk ook informatie uit andere bronnen dan van Wageningen Economic Research en CBS.

Verder maakt deze jaarlijkse publicatie deel uit van een tweeluik, want het project 'Staat van Landbouw en Voedsel' omvat ook een website. Deze moet op een toegankelijke manier een actueel overzicht gaan bieden van relevante data voor LNV. De website zal vooral bestaan uit cijfers, kengetallen en indicatoren, de jaarlijkse publicatie bundelt deze data en voorziet deze van duiding en context. De onderhavige publicatie loopt vooruit op de website, waarvan de lancering in de loop van 2022 is voorzien.

\subsection{Aanpak, opbouw rapport}

De opbouw van deze publicatie is als volgt. In hoofdstuk 2 komt de agrosector in brede zin, dus het complex van primaire landbouw, verwerking en toelevering aan de orde en wordt onder meer ingegaan op de ontwikkeling van de toegevoegde waarde en werkgelegenheid en de buitenlandse handel.

Hoofdstuk 3 gaat in op de consumptie van voedsel en geeft onder meer informatie over de verkoopkanalen van voeding, de uitgaven aan voeding, daarbij inbegrepen de uitgaven aan duurzame voeding en biologische voedsel.

Hoofdstuk 4 gaat in meer detail in op de ontwikkelingen in de land- en tuinbouw en geeft analyses van de ontwikkelingen in de productiefactoren (grond, arbeid, kapitaal), het aantal bedrijven en de inkomensontwikkelingen. Ook komen investeringen en innovaties aan bod, evenals een vergelijking van de inkomens van agrarische ondernemers in Nederland en in andere EU-landen. 
Hoofdstuk 5 beschrijft de overige agribusiness. Hierbij komen aan de orde: bedrijvendynamiek en werkgelegenheid, ontwikkelingen in innovatie, R\&D en investeringen in materiële vaste activa.

Hoofdstuk 6 ten slotte gaat in op de gevolgen van agrarische productie op de omgeving, waarbij onder meer de bijdrage van de agrosector aan de duurzaamheidsdoelen (SDG's) aan de orde komt evenals de thema's broeikasgassen, emissies nutriënten, gewasbeschermingsmiddelen en fijn stof. Ook is er aandacht voor de bijdrage van de landbouw aan natuurbeheer. Het dossier stikstof komt niet aan de orde, de problematiek rondom stikstof wordt via andere publicaties naar buiten gebracht.

De publicatie is tot stand gekomen dankzij de bijdragen van vele auteurs (zie bijlage 1 ), op basis van literatuur- en dataonderzoek. De publicatie geeft in de verschillende bijdragen de hoofdlijnen weer van de ontwikkelingen in de agrosector, via agrimatie. $\mathrm{nl}$ is veelal verdieping naar bedrijfstypering of specifieke producten beschikbaar. Dit is aangegeven in de tekst met links naar de relevante onderdelen van de website agrimatie.nl.

Ten slotte geeft bijlage 2 een overzicht van enkele in de Landbouwbegroting opgenomen indicatoren, zodat voor deze indicatoren in één oogopslag duidelijk is 'waar de agrosector staat'. 


\section{De Nederlandse agrosector}

\section{$2.1 \quad$ Inleiding}

Dit hoofdstuk begint met een globale beschrijving van het economisch belang van het Nederlandse agrocomplex in termen van toegevoegde waarde en werkgelegenheid en de langere termijn ontwikkeling hiervan (paragraaf 2.2). Vervolgens worden de verschillende ketens die kunnen worden onderscheiden binnen de agrosector beschreven, met uitzondering van de visserijsector (paragraaf 2.3). Paragraaf 2.4 gaat in op de langere termijn ontwikkeling van de Nederlandse handel in agroproducten. Paragraaf 2.5 ten slotte gaat in op wat er wordt verdiend aan de export.

\subsection{Agrocomplex}

\subsubsection{Algemeen}

De agrarische sector - opgebouwd uit de sectoren landbouw, tuinbouw en visserij - is nauw verweven met andere delen van de economie. Enerzijds is agrarische productie nauwelijks mogelijk zonder toelevering van goederen en diensten zoals veevoer, kunstmest, energie, machines, stallen, kassen, veterinaire en zakelijke diensten; anderzijds vergen ruwe agrarische producten verwerking in de voedingsmiddelenindustrie, handel en distributie voordat ze op het bord van de consument terechtkomen. Het geheel van directe en indirecte activiteiten rond de agrarische sector kan als een samenhangende keten worden gezien, die vaak wordt aangeduid als het agrocomplex.

\section{De keten in beeld}

In deze benadering staan de primaire sector en de verwerkende industrie van voedings- en genotmiddelen centraal en wordt de omvang van het agrocomplex bepaald door wat de primaire sector en de verwerking nodig hebben van toelevering en logistiek om de producten voort te brengen. De primaire sector is samen met de verwerking feitelijk de spin in het grotere web van agroactiviteiten. Deze insteek is historisch gegroeid en geeft zo de mogelijkheid een keten 'van grond tot mond' in beeld te brengen. Dit verklaart ook waarom de invoer en verwerking van producten als koffie, thee en cacao is inbegrepen in de cijfers, maar de export van toeleveranciers aan buitenlandse primaire producenten en verwerkers niet.

De agrosector is onderdeel van de bredere bio-economie, waarbij bio-economie is gedefinieerd als het geheel van activiteiten dat is gerelateerd aan de productie van biomassa en het omzetten daarvan in voedsel, veevoer, energie, materialen (textiel, pulp, papier) of grondstoffen voor bijvoorbeeld de chemische industrie.

Agrocomplex draagt iets minder dan 7\% bij aan het bruto binnenlands product

De toegevoegde waarde van het totale agrocomplex bedroeg in 2019 - het meest recente jaar waarvoor de cijfers beschikbaar zijn - circa 56 mld. euro. Hiermee komt het agrocomplex 4\% (2 mld. euro) hoger uit dan in 2018. Omdat de nationale economie harder groeide dan het agrocomplex is de bijdrage van het totale agrocomplex aan het bruto binnenlands product (bbp) licht gedaald tot net onder de $7 \%$. Het aandeel in het nationale totaal schommelde de laatste jaren rond de $7,2 \%$ (figuur 2.1 ).

Een deel van de activiteiten van het totale agrocomplex hangt samen met de verwerking van geïmporteerde agrarische grondstoffen, zoals cacao, granen, soja en tabak. De toegevoegde waarde van het agrocomplex gebaseerd op buitenlandse agrarische grondstoffen is ongeveer $2,8 \%$ van het bbp; die van het agrocomplex gebaseerd op binnenlandse agrarische grondstoffen ligt het laatste decennium rond de 4,4-4,8\% en kwam in 2019 uit op 4,1\% (circa $33 \mathrm{mld}$. euro). In het deel van het agrocomplex dat enkel gebaseerd is op binnenlandse agrarische grondstoffen, waren toelevering (36\%) en primaire productie (33\%) samen verantwoordelijk voor bijna $70 \%$ van de toegevoegde waarde. 


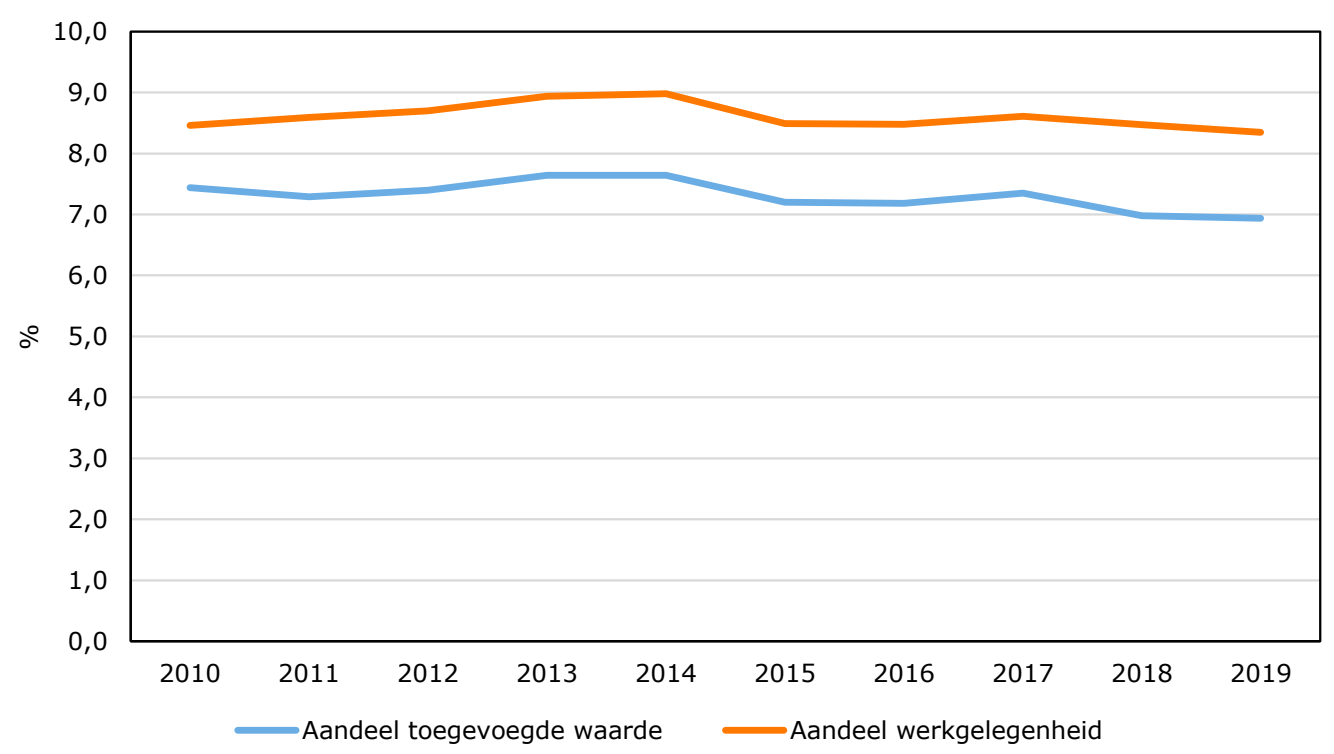

Figuur 2.1 Aandeel agrocomplex in de Nederlandse economie, in toegevoegde waarde en werkgelegenheid Bron: Wageningen Economic Research.

Agrocomplex in 2019 verantwoordelijk voor 8,3\% van de nationale werkgelegenheid

De werkgelegenheid in het totale agrocomplex is gegroeid tot ruim 656.000 arbeidsjaren in 2019, wat circa $8,4 \%$ is van de nationale werkgelegenheid. De totale werkgelegenheid in het op binnenlandse agrarische grondstoffen gebaseerde agrocomplex is in 2019 toegenomen tot meer dan 435.000 arbeidsjaren. Primaire productie en toelevering voorzien met totaal $73 \%$ in de meeste werkgelegenheid, met een aandeel van respectievelijk 40\% (ruim 176.000 arbeidsjaren) ${ }^{1}$ en $33 \%$ (ruim 146.000 arbeidsjaren).

Door de jaren heen schommelt de toegevoegde waarde per arbeidsjaar wat. Gemiddeld komt deze uit rond de 85.000 euro. Met circa 104.000 euro is deze het hoogst in de verwerking van buitenlandse agrarische grondstoffen en het laagst in de primaire sector, namelijk circa 62.000 euro. In alle onderdelen van de productiekolom is er een toename van de toegevoegde waarde per arbeidsjaar in vergelijking met 2018.

Akkerbouw grootste deelcomplex met dank aan verwerking buitenlandse agrarische grondstoffen Het akkerbouwcomplex is wat betreft toegevoegde waarde met bijna 27 mld. euro in 2019 het grootst binnen het totale agrocomplex. Dit is in belangrijke mate gebaseerd op de verwerking van buitenlandse agrarische grondstoffen zoals koffie, thee, cacao, en plantaardige oliën en vetten. Ook de verwerking en invoer van veevoergrondstoffen wordt toegerekend aan het akkerbouwcomplex, voor het deel dat aan nietlandbouwsectoren levert of exporteert. De rest van de invoer van veevoergrondstoffen is inbegrepen bij de toelevering aan de veehouderijsectoren.

Op de tweede plaats staat het grondgebonden veehouderijcomplex met ruim 8,5 mld. euro.

\section{Grondgebonden veehouderij grootste deelcomplex verwerking binnenlandse agrarische grondstoffen}

Binnen het agrocomplex gebaseerd op de productie en verwerking van binnenlandse agrarische grondstoffen heeft het grondgebonden veehouderijcomplex het grootste aandeel in de toegevoegde waarde (26\%) en de werkgelegenheid (33\%). Het aandeel in de toegevoegde waarde was rond de $22 \%$ voor het intensieve veehouderijcomplex en het glastuinbouwcomplex, voor het akkerbouwcomplex was het $17 \%$. Het aandeel in de werkgelegenheid was rond de $16 \%$ voor het akkerbouwcomplex, $18 \%$ voor het glastuinbouwcomplex en voor het intensieve veehouderijcomplex ligt het rond de 22\%. Binnen het agrocomplex gebaseerd op binnenlandse agrarische grondstoffen is de primaire productie in de (glas)tuinbouw en visserij bijna voor twee derde verantwoordelijk voor de toegevoegde waarde. In de akkerbouw en grondgebonden veehouderij ligt dit aandeel met respectievelijk circa $20 \%$ en $15 \%$ een stuk lager. In de glastuinbouw en visserij gaat het veelal om producten die zonder verdere verwerking worden afgezet.

1 Dit cijfer wijkt af van het cijfer in paragraaf 4.2.3 als gevolg van een verschil in de afbakening van de primaire sector, die in het agrocomplex ruimer is en het gebruik van verschillende bronnen. 
Export levert grote bijdrage aan toegevoegde waarde en werkgelegenheid agrocomplex

Een belangrijk deel van de activiteiten van het agrocomplex hangt samen met de export van onbewerkte en bewerkte agrarische producten. De export draagt voor circa driekwart bij aan de toegevoegde waarde en de werkgelegenheid van het totale agrocomplex. Per deelcomplex loopt deze exportafhankelijkheid licht uiteen: van $71 \%$ voor het akkerbouwcomplex tot $85 \%$ voor het glastuinbouwcomplex.

Wegens een revisie van de cijfers kunnen deze afwijken van eerder gepubliceerde cijfers.

Verder lezen

Zie agrimatie voor een nadere analyse van de verschillende deelcomplexen die worden onderscheiden binnen het totale agrocomplex. ${ }^{2}$

\subsubsection{Ontwikkeling agrocomplex op langere termijn}

Tot aan het begin van de jaren negentig groeide de (primaire) landbouw - gemeten in toegevoegde waarde in Nederland ongeveer even snel als de rest van de economie (Stolwijk, 2004). Daarmee was de sector een uitzondering in vergelijking met andere Westerse landen, waar de groei van de landbouw achterbleef. Toch nam het aandeel van de Nederlandse landbouw in het BNP af, als gevolg van achterblijvende prijzen. Deze ontwikkeling kenterde rond 1995, als de groei van de productie stagneert en de prijzen van landbouwproducten sneller dalen dan in de decennia daarvoor. In de periode 1990-2002 daalde het aandeel van de landbouw in het BNP van 4,1\% naar 2,2\%. De Nederlandse landbouw was in een versneld proces van economische marginalisatie terechtgekomen, aldus Stolwijk. De vraag is hoe bovenstaande analyse uitpakt voor de periode 2000-2020.

\section{Ontwikkeling sinds 2002 vergelijkbaar met 1990-2002}

In de eerste tien jaar van de 21 e eeuw daalde het aandeel van het agrocomplex licht, van 10,2\% naar $10 \%$ aandeel in de toegevoegde waarde van de Nederlandse economie. De oorzaak was vooral het achterblijven van de prijsontwikkeling van land- en tuinbouwproducten bij de gemiddelde prijsstijging in Nederland (Berkhout en Roza, 2012).

Wat dit generieke cijfer niet laat zien, zijn de verschillen in de ontwikkeling per onderdeel van het agrocomplex. Binnen het agrocomplex wordt een deel op basis van binnenlandse grondstoffen en een deel op basis van buitenlandse grondstoffen onderscheiden. Waar het aandeel van het complex op basis van buitenlandse grondstoffen groeide, nam het aandeel op basis van binnenlandse grondstoffen af. Vooral het aandeel van de primaire landbouw daalde, van 1,9\% in 2001 tot $1,3 \%$ in 2010 .

De ontwikkelingen in de periode 2010-2020 volgen hetzelfde patroon. Het aandeel van het agrocomplex in de nationale economie daalt verder en schommelt de laatste jaren rond de $7 \%$. De toegevoegde waarde van de rest van de economie groeit harder (figuur 2.2). Het relatieve aandeel van het complex op basis van buitenlandse grondstoffen neemt toe: Nederland wordt steeds meer een land dat waarde toevoegt aan buitenlandse grondstoffen. Binnen het complex op basis van binnenlandse grondstoffen is het aandeel van de primaire landbouw behoorlijk constant, en neemt het aandeel van de verwerkende industrie enigszins toe.

2 https://www.agrimatie.nl/PublicatiePage.aspx?subpubID $=2525 \&$ sectorID $=3534$ \&themaID $=2280$ 


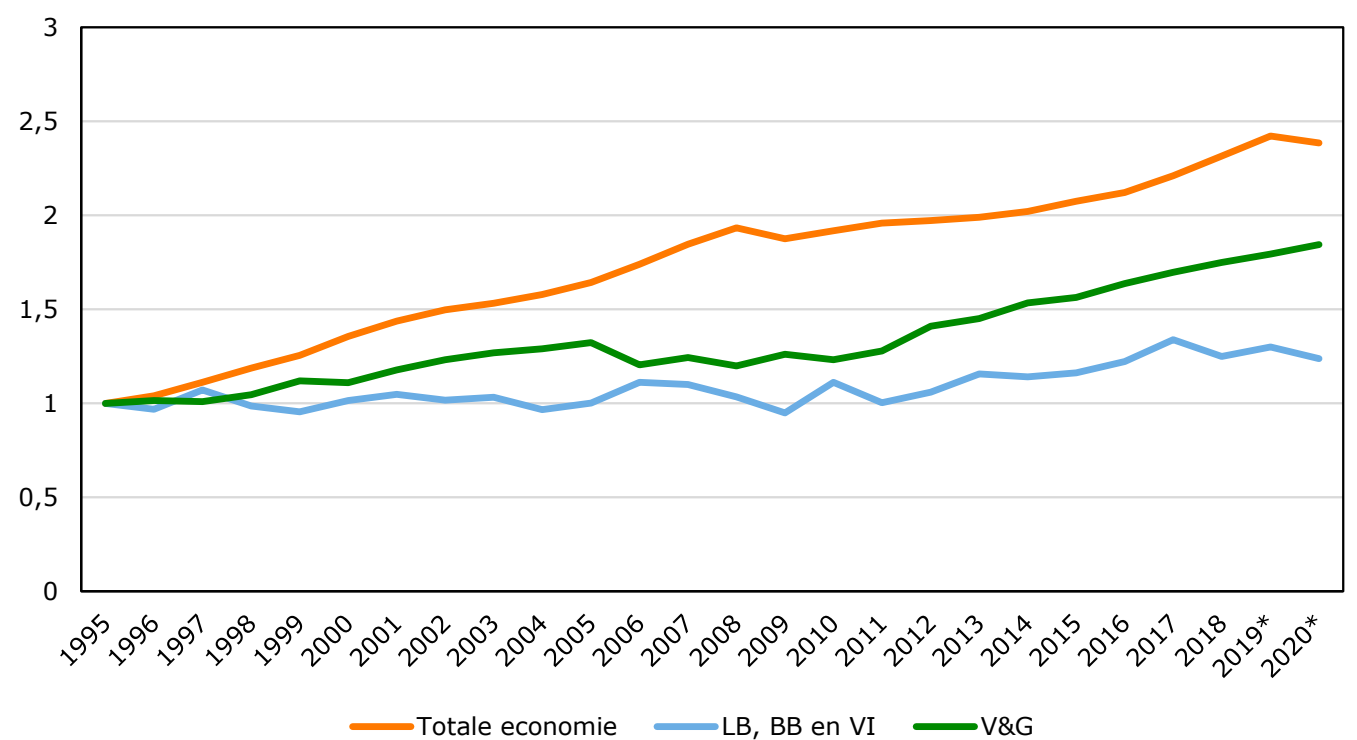

Figuur 2.2 Jaarlijkse groei toegevoegde waarde totale economie, primaire landbouw, bosbouw en visserij en voedings- en genotmiddelenindustrie, 1995-2020 Bron: Nationale rekeningen, bewerking Wageningen Economic Research.

Als we de ontwikkeling van de toegevoegde waarde (binnenlandse deel) uitsplitsen naar volume en prijs, dan blijkt de volumegroei de laatste 20 jaar zeer beperkt en te variëren tussen de -3 en $+4 \%$. Voor de prijsontwikkeling ligt het anders, de stijging van de inputprijzen (intermediair verbruik) is sinds 2000 veel groter dan de stijging van de outputprijzen. Anders gezegd, de ruilvoet is verslechterd (figuur 2.3).

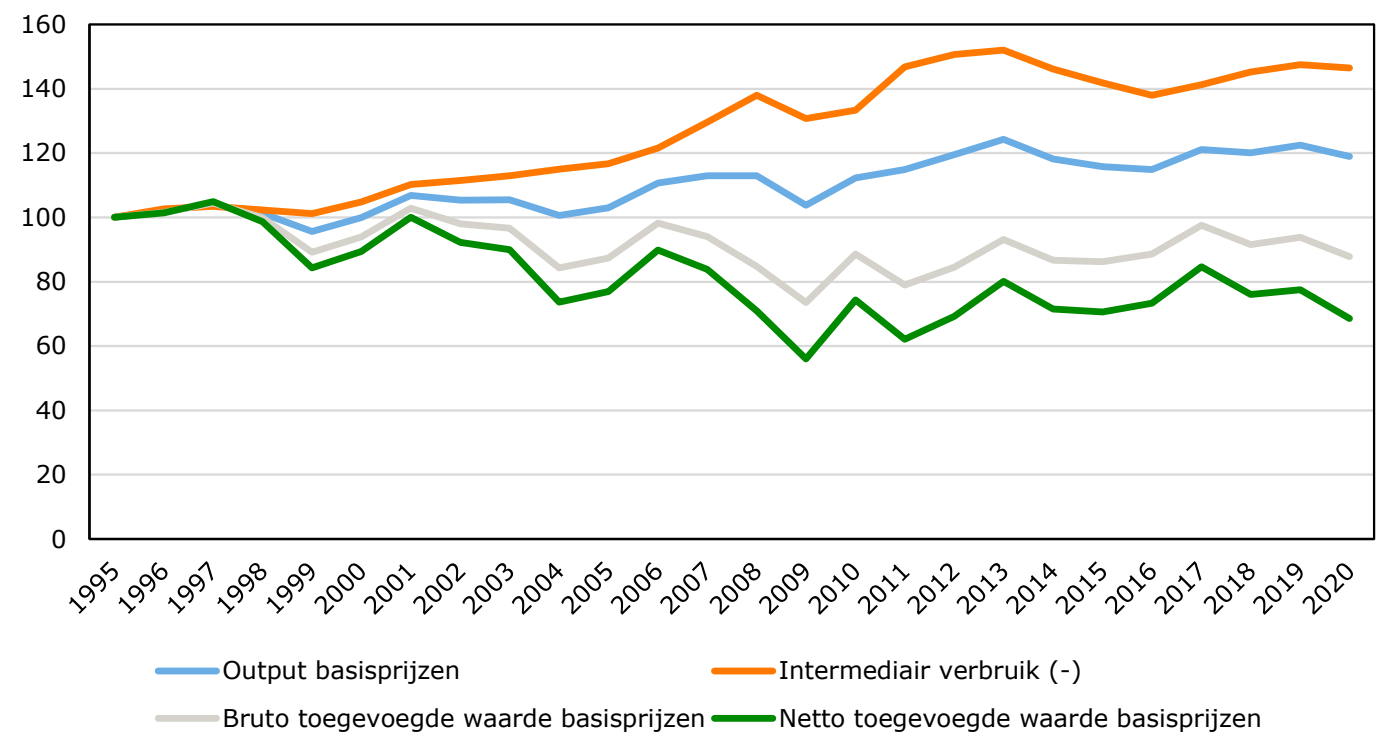

Figur 2.3 Ontwikkeling prijzen (index, 1995=100)

Bron: Nationale rekeningen, bewerking Wageningen Economic Research.

Dankzij de toename van de arbeidsproductiviteit, vooral dankzij de toepassing van arbeidsbesparende technieken, in de periode 2000-2020 konden de inkomens nog redelijk op peil blijven. Stolwijk geeft aan dat in de periode 1990-2002 de arbeidsproductiviteit in de Nederlandse landbouw gemiddeld met iets meer dan $2,1 \%$ per jaar is toegenomen en vooral na 1995 de groei van de arbeidsproductiviteit blijkt te stagneren. De cijfers voor de periode 2000-2020 geven aan dat de arbeidsproductiviteit tot 2016 toeneemt, maar sinds 2015 weer wat stagneert. 
De stijgende arbeidsproductiviteit is ook weerspiegeld in de ontwikkeling van het gemiddelde inkomen. Op basis van het 5 -jarig gemiddelde is er, ondanks de grote jaarlijkse fluctuaties, een stijgend inkomen uit bedrijf (figuur 2.4)

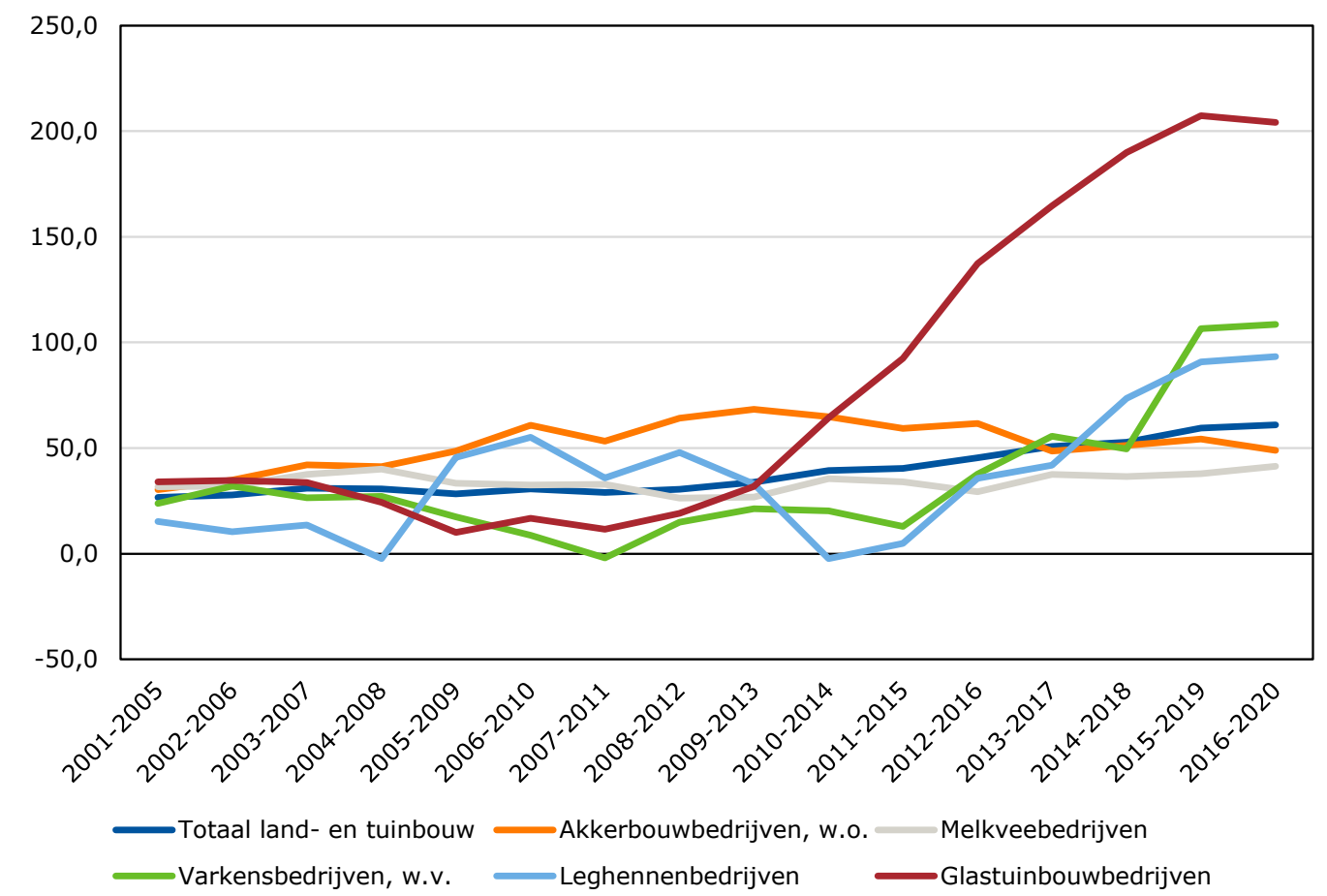

Figuur 2.4 Ontwikkeling inkomen uit bedrijf (in 1.000 euro) per onbetaalde aje, 5-jaarsgemiddelde, 2001-2020

Bron: Wageningen Economic Research.

\subsubsection{Levensmiddelenindustrie}

Een belangrijk onderdeel van het agrocomplex is de levensmiddelenindustrie. Door de Federatie Nederlandse Levensmiddelenindustrie (FNLI) wordt jaarlijks een uitgebreide monitor uitgebracht, die ingaat op diverse kengetallen en thema's behandelt die relevant zijn voor de levensmiddelenindustrie. ${ }^{3}$

\subsection{Ketens in beeld}

\subsubsection{Inleiding}

In de afgelopen jaren heeft Wageningen Economic Research diverse ketens in de Nederlandse agrosector in meer detail in beeld gebracht. Daarbij zijn 10 ketens onderscheiden, die ongeveer iedere 2 jaar werden geactualiseerd. In 2020 zijn de ketens voor de sectoren varkens, pluimvee, eieren en zuivel voor het laatst bijgewerkt, deze geven daarom niet de meest recente ontwikkelingen. In 2021 zijn de ketens voor granen, suikerbieten, aardappelen, groente en fruit, sierteelt en vleeskalveren geactualiseerd. In deze paragraaf zijn al deze ketenbeschrijvingen opgenomen.

\subsubsection{Granen}

Graan is met 180.000 ha (exclusief snijmais), $34 \%$ van het Nederlandse akkerbouwareaal, in oppervlakte gemeten een van de meest voorkomende akkerbouwgewassen in Nederland (CBS, 2021). Van deze 180.000 ha is nog geen 4.000 ha biologisch (CBS, 2021j). De teelt van granen vindt voor een belangrijk deel

3 https://www.fnli.nl/wp-content/uploads/2021/10/2109_Monitor2021_FNLI.pdf 
plaats op kleigrond en wordt vanwege de vruchtwisseling vaak in het bouwplan opgenomen. De afgelopen jaren bedroeg de graanproductie (exclusief mais) in Nederland circa 1,7 mln. ton, minder dan $1 \%$ van de productie in de EU-27. De mondiale graanmarkt is zeer volatiel. De rol van Nederland als aanbieder op de internationale graanmarkt is dan ook van geringe betekenis.

Het belangrijkste graangewas in Nederland is tarwe. Tarwe is te verdelen in harde tarwe en zachte tarwe. Harde tarwe wordt gebruikt voor het maken van pasta, bulgur en couscous, hiervoor is bijvoorbeeld durum tarwe geschikt. Zachte tarwe wordt gebruikt voor het maken van brood, koek, ontbijtgranen en voor veevoer. In Nederland wordt bijna geen harde tarwe geproduceerd vanwege het klimaat. De landelijke productie van circa $1,2 \mathrm{mln}$. ton is dan ook vrijwel volledig zachte tarwe (figuur 2.5 ). Sinds de eeuwwisseling nam het aandeel van tarwe toe van 65\% naar 75\% van het totale graanareaal in 2014, en ligt in 2019 op $67 \%$ van het areaal. Een klein deel van de geoogste tarwe wordt afgezet als zaaizaad: in 2021 certificeerde de Nederlandse Algemene Keuringsdienst (NAK) 2.380 ha wintertarwe en 360 ha zomertarwe (NAK, 2021). Andere graangewassen zijn gerst (brouwgerst), rogge en haver.

\section{Veevoerindustrie belangrijkste afzetkanaal tarwe}

Van de Nederlandse tarwe vindt slechts op beperkte schaal verkoop aan maalderijen plaats ten behoeve van de bloemproductie; een groot deel van de in Nederland geteelde tarwe is vanwege de ontoereikende kwaliteit (met name het lage eiwitgehalte) niet bakwaardig. De maalindustrie is dus in grote mate aangewezen op importtarwe uit Frankrijk en Duitsland.

Veruit het grootste deel van het Nederlandse tarweaanbod vindt zijn weg naar de veevoerindustrie en wordt verwerkt in mengvoeders. Het aanbod van binnenlandse tarwe is onvoldoende om aan de vraag vanuit deze sector te voldoen, zodat veel voertarwe uit Frankrijk en Duitsland wordt geïmporteerd. Daarnaast wordt de tarwe bestemd voor de productie van bioethanol, zaaizaad, of de export.

Dossche Mills, die in 2018 Meneba overnam, is één van de grootste maalderijen in Europa. Deze onderneming heeft een groot marktaandeel in de Nederlandse brood- en banketmarkt. Daarnaast kent Nederland nog twee middelgrote maalderijen en een aantal kleinere. Tussen maalderijen en bakkerijen bevinden zich de bedrijven die bakkerijgrondstoffen produceren. Zij mengen en verwerken meel met ingrediënten uit andere ketens, zoals oliën en vetten, suiker, eieren, en enzymen tot halffabricaten (mixen) en broodverbetermiddelen voor de bakkerijen. Bakkerijen worden onderscheiden in industriële en ambachtelijke bakkerijen. Dit onderscheid lijkt geleidelijk aan te vervagen als gevolg van schaalvergroting onder ambachtelijke bakkerijen.

Een ontwikkeling is de lokale of regionale teelt van granen bestemd voor de productie van broden die typisch zijn voor de streek. Een aantal fabrikanten van meel en bloem werkt samen met lokale bakkers aan de teelt en verwerking van specifieke granen die vervolgens door aangesloten bakkers worden verwerkt (onder andere Fryske Bôle, Polderbruin, Zeeuwse vlegel). Ook de hernieuwde belangstelling voor 'oude' graansoorten zoals spelt en granen die glutenvrij zijn, geeft de bakkerijindustrie kansen om nieuwe producten te ontwikkelen.

De broodconsumptie in Nederland is de laatste 10 jaar dalende. Van ruim $1 \mathrm{mln}$. ton brood per jaar in 2009 naar 0,82 $\mathrm{mln}$. ton brood in 2020. In $2020 \mathrm{komt}$ dat neer op ongeveer $50 \mathrm{~kg}$ brood per persoon per jaar. Van de in brood en banket verwerkte granen bestaat 80-90\% uit tarwe (mondelinge mededeling Nederlands Bakkerij Centrum). Daarnaast worden andere granen in brood verwerkt. Andere producten die op basis van met name tarwemeel/bloem gemaakt worden zijn: koek en banket, beschuit en snacks, pizza, en pasta.

\section{Nederland grootste bierexporteur van Europa}

Met een productie van circa 250.000 ton per jaar is gerst na tarwe het belangrijkste graangewas met als bestemmingen de binnenlandse markt en export. Een deel van de geoogste gerst wordt afgezet aan binnenlandse en buitenlandse mouterijen ten behoeve van de productie van mout voor de bierindustrie. Nederlandse mouterijen zijn daarnaast ook aangewezen op geïmporteerde gerst en mout. Nederland importeert 290.000 ton mout uit Europa, de export bedroeg 300.000 ton mout. ${ }^{4}$ Grote mouterijen in Nederland zijn Cargill (te Swalmen), The Swaen (te Kloosterzande) en Holland Malt (te Eemshaven en

\footnotetext{
4 www.euromalt.be
} 
Lieshout). De productiecapaciteit van de Nederlandse mouterijen bedraagt 503.000 ton in $2019 .{ }^{5}$ De mout wordt afgenomen door de binnen- en buitenlandse bierindustrie.

Nederland was in 2020 de grootste bierexporteur van de EU. De Nederlandse bierbrouwers exporteerden in 2020 voor 1,9 mld. euro aan bier (inclusief alcoholvrij) (CBS, 2021). Nederland telt 850 brouwerijen inclusief acht grote brouwerijen, waaronder Heineken, Grolsch en Bavaria. De toegenomen belangstelling voor ambachtelijk, lokaal bier heeft de opkomst van minibrouwerijen sinds 2010 gestimuleerd.

De gerst die niet aan de kwaliteitseisen van de mouterijen voldoet, wordt als voergerst afgezet aan de veevoederindustrie. De vraag vanuit de veevoederindustrie overtreft in ruime mate het binnenlandse aanbod waardoor een aanzienlijke invoer van voergerst plaatsvindt. De productie van andere graansoorten als triticale, rogge, haver en korrelmais is van weinig betekenis. Afzet van deze granen vindt zowel plaats naar de humane voedingsmiddelenindustrie als naar de veevoerindustrie.

\section{Pool en collecterende handel}

Gezien de grote afhankelijkheid van de import wordt de graanprijs in Nederland sterk bepaald door de (prijs)ontwikkelingen in de naburige landen en op de wereldmarkt. Telers kunnen direct na de oogst het graan verkopen of zelf opslaan. Ook bestaat de mogelijkheid het graan bij de coöperatieve of private collecterende handel op te slaan, in de verwachting dat de prijzen in de loop van het seizoen gaan stijgen. De collecterende handel (onder andere Agrifirm, CZAV) beschikt over regionale innamepunten, waar het graan direct na oogst wordt ingezameld, en van daaruit getransporteerd naar locaties met grote silo's waar het graan wordt gedroogd, geconditioneerd en bewerkt en gedurende het jaar wordt opgeslagen tot het verkocht is. Een alternatieve mogelijkheid die Agrifirm aanbiedt, is het graan los op het erf te storten en binnen een week door de collecteur te laten ophalen. Voordeel is dat de teler transport minimaliseert en tijdens de oogsttijd effectiever en slagvaardiger kan opereren.

Een belangrijk deel van het geoogste graan zetten telers echter af in een pool. Het beheren van de pool gebeurt door de collecteur die regelmatig partijen van het ingenomen graan verkoopt. Op deze wijze probeert de collecteur voor de deelnemende telers een zo goed mogelijke seizoengemiddelde prijs te realiseren en uitslagen naar beneden of boven te voorkomen. Grote collecteurs zoals Agrifirm optimaliseren hun logistiek door graanopslag te centraliseren en een meerjarige samenwerking aan te gaan met gespecialiseerde overslagbedrijven (Graansloot Kampen: 275.000 ton opslagcapaciteit).

Het werkgebied van de collecterende handel beperkt zich meestal tot een bepaalde regio in Nederland. In het zuidwestelijk kleigebied vervult de CZAV een vooraanstaande rol bij de graaninkoop. Het werkgebied van Agrifirm bestrijkt de zuidelijke provincies en het gebied boven de rivieren. De particuliere graanhandel werkt afhankelijk van de bedrijfsomvang, veelal meer binnen de lokale regio.

${ }^{5}$ www.euromalt.be 


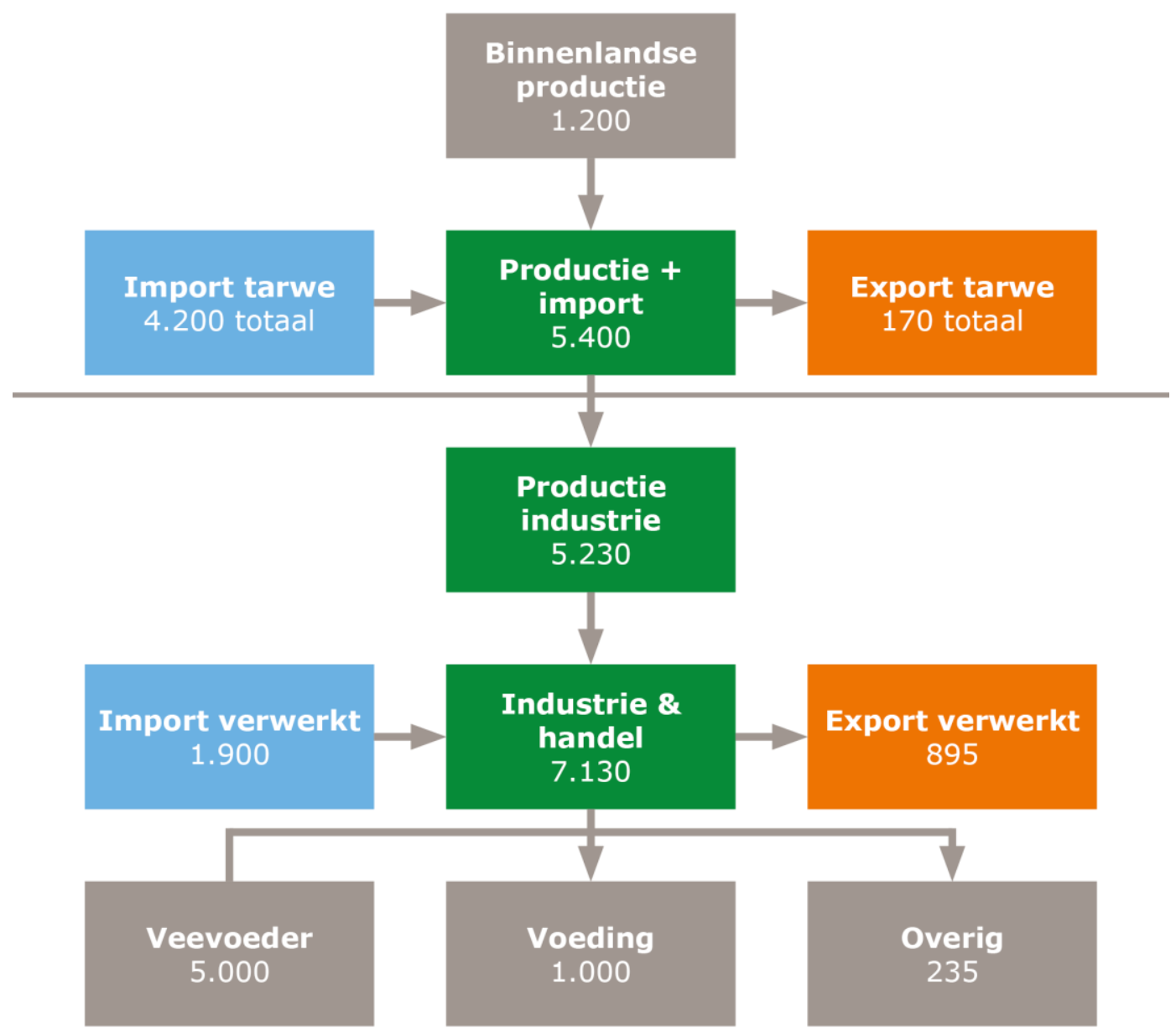

Figuur 2.5 Globaal stroomschema tarwe, 2019 (*1.000 ton)

Bron: Eurostat, bewerking Wageningen Economic Research.

\subsubsection{Suiker}

In Nederland werd in 2020 op ongeveer 7.600 akkerbouwbedrijven in totaal 81.000 ha suikerbiet geteeld (agrimatie). De teelt vindt voornamelijk plaats op kleigrond, maar deels ook op zand-, dal- en lössgronden. De bieten worden verwerkt door Cosun Beet Company, een dochter van coöperatie Cosun. Cosun Beet Company heeft in Nederland twee suikerfabrieken, namelijk in Dinteloord (Noord-Brabant) en Vierverlaten (Groningen). Daarnaast is er nog een fabriek in Anklam, Duitsland. Na diverse fusies is in Nederland alleen Cosun Beet Company als suikerbietverwerker/suikerproducent overgebleven.

Het belangrijkste product van de verwerking van suikerbieten is kristalsuiker. Kristalsuiker wordt als zodanig (in de vorm van losse kristalsuiker en suikerklontjes) aan de consument verkocht; een groter deel van de suiker dient als grondstof voor de suikerverwerkende industrie, bijvoorbeeld voor de productie van frisdrank, brood, gebak en andere voedingsmiddelen. Daarnaast is suiker een grondstof voor 'biobased' toepassingen, waarvan bio-ethanol de meest bekende en wijdst verbreide is. Zo draait de transportsector in Brazilië, de grootste rietsuikerproducent in de wereld, op bio-ethanol. Ook in Duitsland en Frankrijk gaat $10 \%$ van de bieten de ethanol in. Suiker is goed voor meer dan $60 \%$ van de wereldwijde productie van ethanol.

De suikerketen in Nederland wordt gedomineerd door de teelt en verwerking van suikerbieten. Daarnaast kan ook suikerriet als bron van suikerproductie dienen, maar die stroom is in Nederland klein, mede omdat suikerriet een tropisch gewas is en suikerriet dus geïmporteerd moet worden. Suikerbiet gedijt in een gematigd klimaat. Bij hoge temperaturen is de onderhoudsademhaling hoog en dat gaat ten koste van de netto-suikerproductie. Daarom wordt suikerbiet geteeld in de gematigde gebieden in de EU en NoordAmerika en suikerriet in tropische gebieden, zoals Afrika, India en Zuid-Amerika. Vanuit concurrentieoogpunt is suikerbiet een interessant gewas gezien de hoeveelheid suiker per ha. De Europese suikerverwerkende industrie heeft een voorkeur voor Europese (biet)suiker, omdat hun productieproces is afgestemd op de 
kristalstructuur van deze suiker en omdat men veel waarde hecht aan voedselveiligheid; die lijkt beter gewaarborgd in de Europese teelt en industrie dan elders.

\section{Overzicht van de suikerbiet- en suikerstromen}

Figuur 2.6 geeft een overzicht van de suikerbiet- en suikerstromen in Nederland voor 2020, het meest recente jaar waarvoor deze gegevens beschikbaar zijn. In dat jaar werd op ruim 81.000 ha ruim 6,8 mln. ton suikerbieten geoogst, goed voor ruim 1,1 mln. ton suiker. Import en export van suikerbieten vindt in geringe mate plaats. Dit betreft met name grensverkeer met Duitsland en België, bedoeld om transportafstanden tot de fabriek te beperken. Daarentegen zijn de import en export van suiker van grote omvang, respectievelijk ruim $1 \mathrm{mln}$. en ruim $2 \mathrm{mln}$. ton. Dit betreft niet alleen import van kristalsuiker maar ook van suiker die verwerkt is in voedingsmiddelen. Het Nederlandse verbruik door consumenten wordt voor 2020 geschat op 381.000 ton ofwel $21,9 \mathrm{~kg}$ per hoofd van de bevolking. 'Suikergebruik industrie + voorraadmutatie' is in dit overzicht een restpost, die in 2020 negatief uitpakt. Dat betekent dat er per saldo meer suiker en 'nietgewonnen suiker' (in bietenpulp, melasse en vinasse) uit voorraad is gegaan dan er is geproduceerd.

Vóór de afschaffing van het suikerquotum per 30 september 2017 bedroeg de zelfvoorzieningsgraad voor suiker in de EU 90\%. Dat betekende ook dat Cosun Beet Company in die tijd ongeveer 20.000 ton rietsuiker per jaar importeerde voor raffinage om aan de vraag van suikerverwerkers te kunnen voldoen. ${ }^{6} \mathrm{Na}$ afschaffing van het quotum is Cosun Beet Company gestopt met deze import en heeft zij de telers ruimte gegeven om het suikerbietenareaal in Nederland met ongeveer $20 \%$ te vergroten tot ongeveer 80.000 ha. Bij de uitzaai in 2017 had men al geanticipeerd op de afschaffing van het quotum en kwam het areaal uit op ruim 85.000 ha; in 2016 was het areaal nog 70.000 ha. Een areaal van 81.000 ha (zoals vanaf 2018) lijkt beter aan te sluiten bij de huidige markt. In 2020 werd in Nederland 1,1 mln. ton suiker geproduceerd, ${ }^{7}$ dus aanzienlijk minder dan de 1,3 mln. ton in 2017.

\section{Teelt van suikerbieten in de EU en Nederland}

Suikerbiet is in Nederland lange tijd een van de belangrijkste akkerbouwgewassen geweest, mede door een relatief hoog saldo (financiële opbrengsten minus toegerekende kosten). Ook voor de EU is het een belangrijk gewas. De EU als geheel teelde in 2018 1,74 mln. ha (website Eurostat d.d. 17 juli 2019) en produceerde in 2018/2019 ongeveer 19,2 mln. ton suiker. ${ }^{8}$ Op wereldschaal werd in $20134,9 \mathrm{mln}$. ha suikerbieten geteeld, met een suikerproductie van ongeveer $43 \mathrm{mln}$. ton. Dit is een kwart van de totale wereldsuikerproductie uit suikerbiet en -riet (Harmsen et al., 2014).

Na de afschaffing van het suikerquotumstelsel namen het areaal suikerbiet en de productie van suiker in de $\mathrm{EU}$ in eerste instantie sterk toe, mede doordat de export van suiker naar de wereldmarkt niet langer beperkt wordt. In 2017 bedroeg het suikerbietenareaal in de EU 1,7 mln. ha tegenover ongeveer 1,4 $\mathrm{mln}$. ha in voorgaande jaren (Smit et al., 2017). Als gevolg daarvan daalden de suikerprijzen op de wereldmarkt sterk, tot een historisch laag niveau. Dit effect werd nog versterkt doordat elf Oost- en Zuid-Europese lidstaten van de EU hebben besloten Voluntary Coupled Support (VCS) gekoppelde steun per ha suikerbiet, in dit geval) aan te vragen voor en toe te kennen aan de suikerbietenteelt in hun land. Daardoor is de prijs voor suikerbieten in de EU nog eens met 5\% extra gedaald (Smit et al., 2017). In 2020 was het areaal door deze ontwikkelingen en ondanks de VCS gedaald tot 1,47 mln. ha (website Eurostat d.d. 6 oktober 2021).

Ook in Nederland heeft het wegvallen van de suikerquotering met name geresulteerd in een areaaluitbreiding naar 85.000 ha in 2017 en 2018. In 2019 en 2020 was het suikerbietenareaal ongeveer 81.000 ha, hoewel Cosun Beet Company voor 2020 inzette op 85.000 ha. De areaaluitbreiding lijkt voor Nederland dus niet blijvend, ongetwijfeld als gevolg van de lage suikerprijzen in de afgelopen jaren. In de overige EU-lidstaten zal een deel van het areaal wegvallen door het sluiten van een aantal suikerfabrieken. Dat effect wordt in elf lidstaten beperkt door de Voluntary Coupled Support (Smit et al., 2017). Nederland heeft hier niet aan meegedaan en ook niet de ons omliggende grote suikerproducenten Frankrijk, Duitsland en het Verenigd Koninkrijk.

\footnotetext{
6 De eerdergenoemde import van suiker is niet alleen bedoeld voor raffinage.

7 www.cosunleden.nl/nieuws/cosun-lagere-bietenprijs-door-tegenvallend-result. Ter vergelijking: in het quotumtijdperk was de jaarlijkse suikerproductie in Nederland ongeveer 800.000 ton (quotum)suiker.

8 www.boerenbusiness.nl/granen-grondstof/artikel/10880097/suikerprijs-ongevoelig-voor-europese-invloed
} 
Door de sterke prijsdaling sinds 2017 was de verwerking van suikerbieten ook in Nederland verliesgevend geworden. Het saldo van suikerbiet is daardoor ook sterk gedaald, maar is vergeleken met de rest van de EU nog steeds op redelijk peil doordat winsten binnen de Cosun-groep (waarvan Cosun Beet Company een dochter is) deels ten goede komen van de uitbetalingsprijs van suikerbieten. In 2020 is er echter weer winst gemaakt door hogere suikerprijzen dan in 2019 (Cosun Jaarverslag 2020). Op termijn verwacht Cosun Beet Company verder prijsherstel, onder andere doordat diverse suikerfabrieken in de EU gesloten worden. ${ }^{9}$

Verder lezen

Op agrimatie staat meer informatie over alternatieve zoetstoffen en de toekomst van de teelt van suikerbieten in NL. ${ }^{10}$

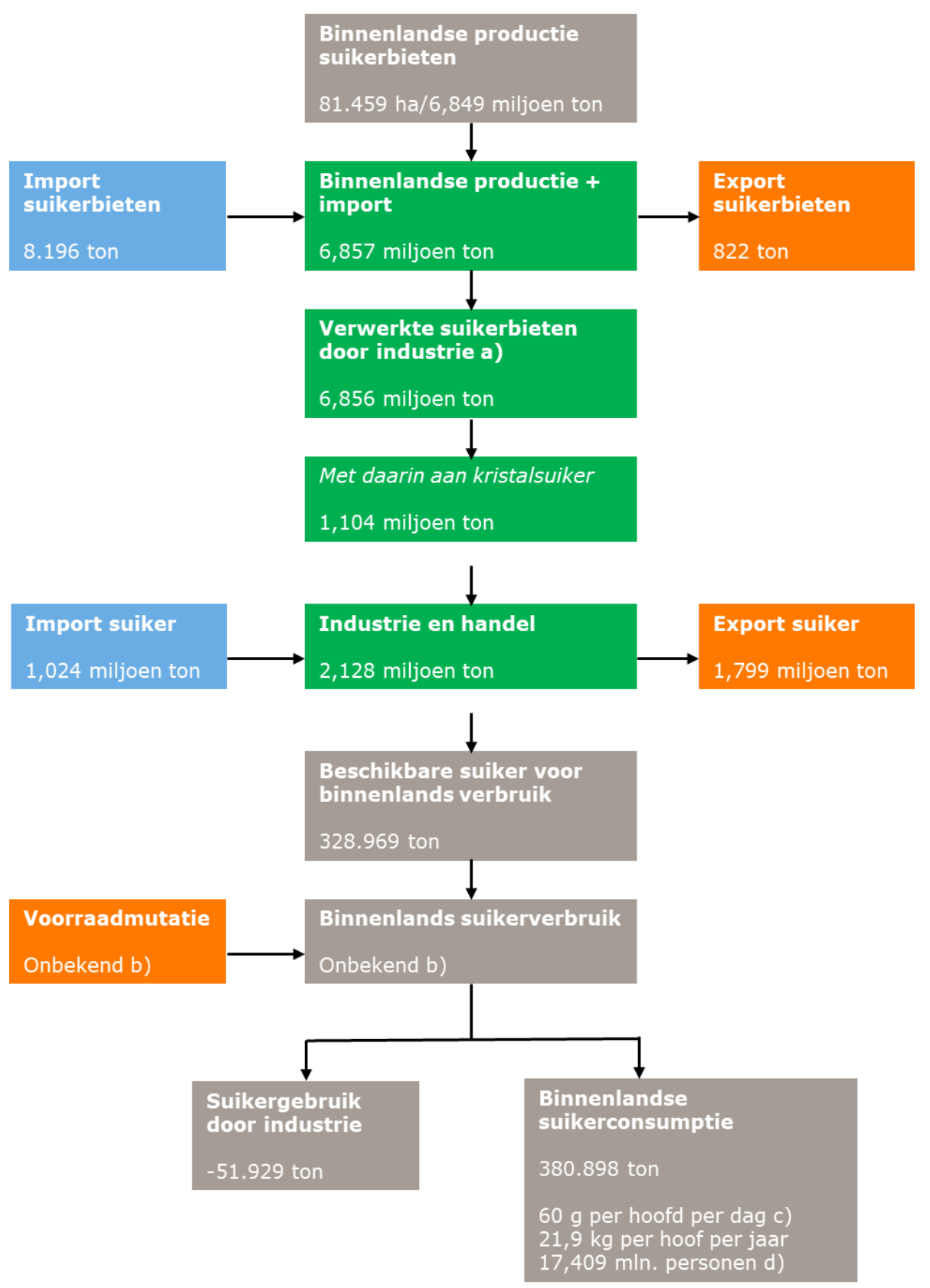

Figuur 2.6 Globaal schema suikerbiet en suikerstromen in Nederland, 2020

a) Met een suikergehalte van 16,1\%; b) Daarom opgenomen in 'restpost' Suikergebruik industrie + voorraadmutatie; c) Bron: https://www.wateetnederland.nl/onderwerpen/suiker; d) Bron: CBS.

\footnotetext{
9 Dat prijsherstel is ook deels gekomen in de loop van 2020 (Cosun Jaarverslag 2020) en er zijn inderdaad suikerfabrieken in Duitsland en Frankrijk gesloten.

${ }^{10}$ https://www.agrimatie.nl/PublicatiePage.aspx?subpubID =2525\&sectorID =7539\&themaID =3577\&indicatorID =3591
} 


\subsubsection{Aardappelen}

Voor aardappelen zijn er drie verschillende afzetmarkten: pootaardappelen, consumptieaardappelen en zetmeelaardappelen. Het totale areaal aardappelen bedroeg in 2020 bijna 166 duizend hectare. In de periode 2010-2020 nam het gemiddelde areaal aardappelen per teler licht toe van 17,0 ha naar 17,3 ha.

\section{Pootaardappelen}

Pootaardappelen zijn aardappelen die het volgende seizoen als uitgangsmateriaal worden gebruikt. In Nederland worden jaarlijks circa 500 verschillende aardappelrassen vermeerderd. De ras-eigenschappen zoals kleur, smaak en verwerkingskwaliteit zijn medebepalend voor de afzetmogelijkheden. Het totale areaal pootaardappelen is afgelopen decennium toegenomen van 38.540 ha in 2010 tot 43.800 ha in 2020. Het aantal pootaardappelbedrijven is vrij stabiel en bedroeg in 20202.370 bedrijven. In-vitro of snelle vermeerdering (de productie van microplantjes, microknollen, vitroplantjes en miniknollen) vormt meer en meer onderdeel bij de eerste vermeerdering van het pootgoedvermeerderingsproces. Een alternatief voor pootgoed is aardappelzaad (true potato seed). Aardappelzaad wordt commercieel aangeboden, maar niet toegepast binnen de Nederlandse pootgoedvermeerdering. Het biedt voordelen voor kleinere boeren in Afrika.

Pootaardappelen moeten voldoen aan hoge kwaliteits- en exporteisen. De Nederlandse Algemene Keuringsdienst (NAK) ziet erop toe dat het aangeboden pootgoed aan de gestelde kwaliteitseisen voldoet. Als de pootaardappelen niet aan de eisen voldoen of als de afzetmarkt te klein blijkt, dan worden ze voor andere bestemmingen verkocht (consumptie, voer, bio-energie). Pootaardappelen brengen veelal hogere prijzen op dan consumptieaardappelen.

De oogst van pootaardappelen in 2020 bedroeg 1,5 mln. ton. Ruim $1 \mathrm{mln}$. ton hiervan werd goedgekeurd door de NAK, dat is circa tweederde. De laatste jaren is deze verhouding niet drastisch veranderd. Ongeveer $70 \%$ van de goedgekeurde pootaardappelen wordt geëxporteerd. Afgekeurde pootaardappelen worden afgezet voor veevoer, drogerij, bio-energie of consumptie mits de aardappels aan de eisen voldoen. Handelshuizen zoals Agrico en HZPC zijn toonaangevende spelers. Van de 731.000 ton (oogst 2020, NAO) pootaardappelexport gaat bijna tweederde (62\%) naar Europese landen (belangrijkste afzetmarkten: België, Duitsland, Italië, Spanje, Frankrijk). Ook Afrika (met name bestemmingen Algerije, Egypte en Marokko) en Azië zijn belangrijke afzetgebieden en goed voor respectievelijk $17 \%$ en $18 \%$ van het Nederlandse exportvolume.

\section{Consumptieaardappelen}

Consumptieaardappelen werden in 2020 geteeld op 6.810 bedrijven. Het areaal is de laatste jaren licht gestegen van 67.300 ha in 2012 naar 76.700 ha in 2020. De productie van consumptieaardappelen ligt de laatste 10 jaar gemiddeld op 3,6 mln. ton. In 2020 lag de oogst een fractie boven dit gemiddelde: 3,7 mln. ton (figuur 2.7).

Hoewel Nederland zelf veel consumptieaardappelen produceert, wordt ook een aanzienlijk volume consumptieaardappelen geïmporteerd. Ook is er beperkte import van verwerkte aardappelen. Nederland kent een grote aardappelverwerkende industrie. Grote marktpartijen zijn Aviko, Farm Frites, McCain en LambWeston/Meijer. Door de Nederlandse productie en het importaanbod te combineren, kunnen deze fabrieken tot een optimaal gebruik van productiecapaciteit komen en hun positie op de wereldmarkt handhaven. De import (in 2019 ruim 1,6 mln. ton) komt met name uit buurlanden. In 2020 verwerkte deze industrie door de coronapandemie minder aardappelen dan normaal. In totaal werd 3,4 mln. ton aardappelen verwerkt tot $1,5 \mathrm{mln}$. ton voorgebakken producten (frites) en 0,3 $\mathrm{mln}$. ton ander verwerkt product (VAVI). Bij het verwerkingsproces komen bijproducten vrij die worden afgezet als vochtrijke voedermiddelen voor de rundvee- en varkenshouderij. In 2020 ging het om 1,1 mln. ton. Daarbovenop is een onbekende hoeveelheid bijproduct afgezet voor bio-vergisting en energieopwekking.

Naast de afzet op de binnenlandse markt wordt een aanzienlijke hoeveelheid aardappelen geëxporteerd (2019: 1,3 mln. ton) door de Nederlandse aardappelhandel en verpakkers. Het meeste gaat naar België en Duitsland. Ook veel verwerkte aardappelen vinden hun weg naar het buitenland; met name het Verenigd Koninkrijk en Duitsland zijn belangrijke exportmarkten. Naast Europa is het Midden-Oosten een belangrijk afzetgebied, vooral Saoedi-Arabië. Ook worden aardappelen geïmporteerd, onder andere tafelaardappelen 
voordat nieuwe Nederlandse aardappelen op de markt komen worden bij aanvang van het seizoen (in de periode mei-juni) nieuwe aardappelen vanuit Zuid-Europa geïmporteerd.

De consumptie van tafelaardappelen in Nederland staat onder druk: consumenten kopen steeds minder en kleinere hoeveelheden verse aardappelen (circa 275.000 ton). Vanwege de jaarlijks licht dalende consumptie van verse aardappelen en kleiner wordende huishoudens komen verpakkers en retailers met kleinere verpakkingseenheden.

De verkoop van verpakte koelverse aardappelproducten in supermarkten ligt op circa 60.000 ton per jaar (wat overeenkomt met een kleine 120.000 ton aardappelen). Ook worden aardappelen verwerkt door kleinere foodbedrijven, horeca en instellingen zoals foodservice en in kant-en-klaarmaaltijden.

\section{Zetmeelaardappelen}

In 2020 teelden 1.590 bedrijven zetmeelaardappelen. Het areaal lag in 2000 rond de 50.000 ha; door wijzigingen in het Europese marktordeningsbeleid daalde dit naar ruim 42.000 ha in 2014 . Sindsdien is het areaal zetmeelaardappelen iets toegenomen tot 45.500 ha in 2020.

Bij zetmeelaardappelen bedraagt de productie ruim 1,8 mln. ton. Zetmeelaardappeltelers zijn lid van de coöperatie Avebe en hebben leveringsrechten om hun aardappelen aan deze verwerker te leveren. De aardappelen worden verwerkt tot zetmeel- en eiwitproducten die wereldwijd worden afgezet aan de voedingsmiddelenindustrie, en ook als ingrediënt voor de veevoederindustrie en voor technische toepassingen. Afgelopen decennia veranderde Avebe van een bulkproducent naar een innovatieve producent van hoogwaardige grondstoffen voor voedingsmiddelen.

\section{Telen op contractbasis}

Het leeuwendeel van alle aardappelen wordt op contractbasis geteeld, bewaard en afgeleverd. Zetmeelaardappelen worden op contract geteeld. Ook pootaardappelen worden veelal op contract geteeld waarbij per ras onder andere afspraken over klasse, maatsortering en leveringsmoment worden vastgelegd. Voor het vermeerderen van pootgoed met kwekersrecht is schriftelijke toestemming van de kweker of zijn vertegenwoordiger nodig en dient een vergoeding aan de kweker of zijn vertegenwoordiger betaald te worden (licentie).

Voor consumptieaardappelen bestaat een grote diversiteit aan contractvormen (zoals hectarecontract, poolcontracten, klikcontract) maar telers kunnen ook kiezen voor de vrije handel of de termijnmarkt. Naast eenjarige contracten worden tegenwoordig ook meerjarige afspraken gemaakt. De prijsinformatie over gedane transacties van vrije aardappelen wordt vastgesteld op de beurs. Eind 2017 is de nieuwe aardappelbeurs PotatoNL van start gegaan (www.potatonl.com). Daarmee heeft Nederland één landelijke aardappelnotering en zijn de noteringen van de beurs Emmeloord, Rotterdam en Goes vervallen. De PotatoNL-notering komt gezamenlijk tot stand na inbreng vanuit teelt, handel en verwerkende industrie.

Er zijn in totaal 10 aardappelnoteringen (rassen en productcategorieën) waarvoor de prijzen door de noteringscommissie worden vastgesteld. De commissie bestaat uit twee leden namens de industrie, twee leden namens de handel en vier telers. De notering verschijnt wekelijks op dinsdag en donderdag en wordt vastgesteld op basis van recentelijk gedane zaken van in Nederland geteelde aardappelen. De notering geeft de telers, handelaren en afnemers informatie over de actuele prijzen die bijvoorbeeld worden gebruikt voor afrekening van de geleverde aardappelen die buiten het contract vallen. De notering wordt ook meegenomen in de korf van Europese noteringen, waaruit de cash settlement-prijs van de termijnmarkt in Frankfurt (Eurex) wordt berekend. Tegen deze notering worden termijncontracten afgewikkeld als de laatste handelsdag voor een contract is verlopen.

Afnemers zoals retailers stellen steeds strengere, bovenwettelijke eisen aan geleverde producten, bijvoorbeeld via het keurmerk On the way to PlanetProof. Het areaal van dit keurmerk is voor aardappelen toegenomen van 245 ha in 2014 tot 6.747 ha in 2020. Het areaal biologische aardappelen bedroeg in 2020 2.054 ha waarvan 1.472 ha consumptieaardappelen en 582 ha pootaardappelen. De aardappelsector werkt aan innovaties om bijvoorbeeld het gebruik van gewasbeschermingsmiddelen te minimaliseren door inzet van moderne teelttechnieken en rassen met een verbeterde ziekteresistentie. Resistentieveredeling via de 
gentechniek Crispr-Cas is voorlopig lastiger in te zetten. Volgens een uitspraak van het Europese Hof (juli 2018) valt deze techniek onder de Europese wetgeving voor genetische modificatie waarop strenge regelgeving van toepassing is. Met het wegvallen van veelgebruikte middelen voor loofdoding en het kiemremmingsmiddel CIPC in 2020 zijn telers aangewezen op duurdere bewaar- en loofdodingsmethoden en -technieken.

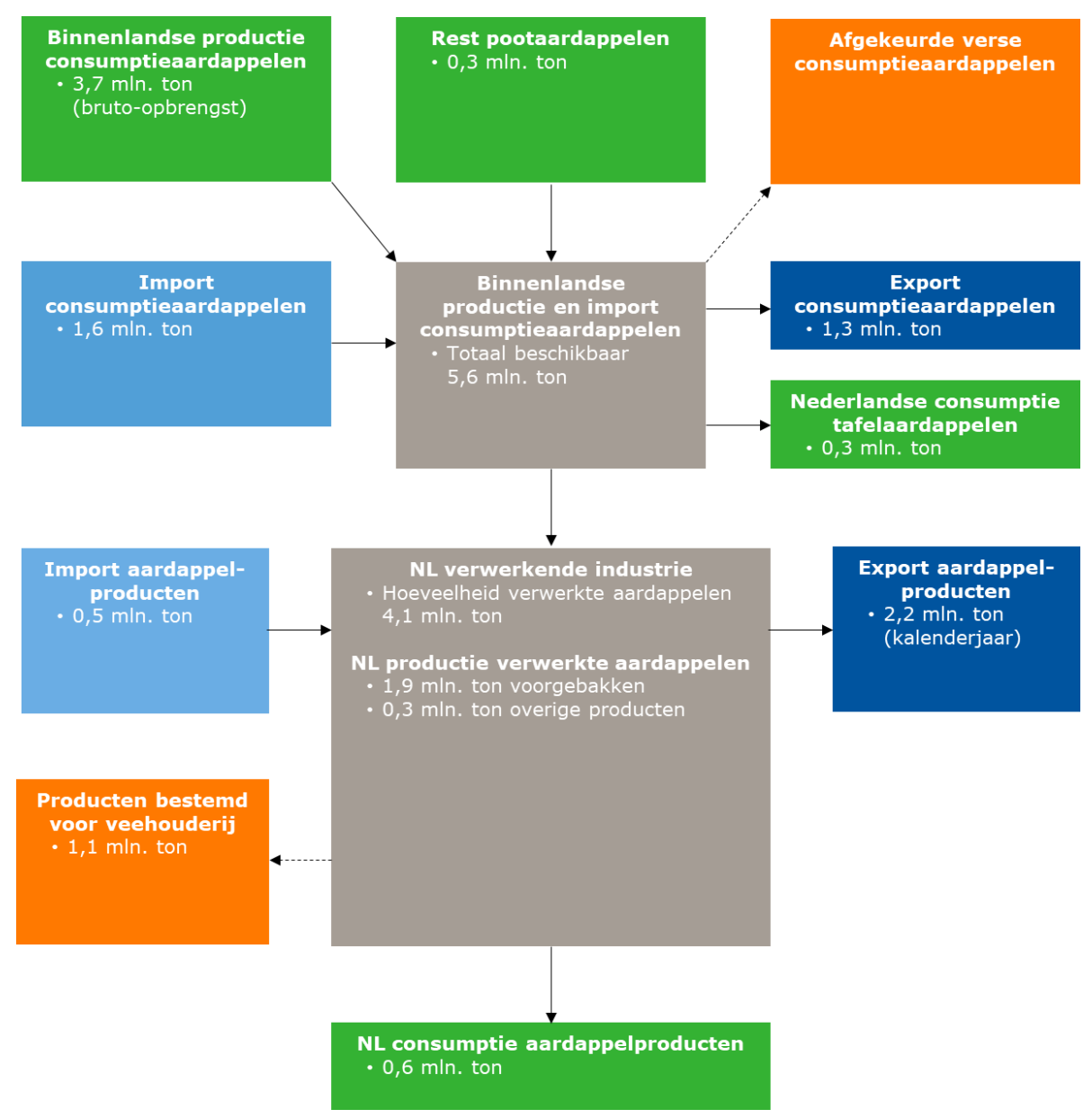

Figuur 2.7 Globaal overzicht van de consumptieaardappelketen, 2019

\subsubsection{Groente- en fruit}

De groenten- en fruitketen is een omvangrijke sector in Nederland en bestaat uit een diversiteit aan gewassen, teeltwijzen en bedrijven. Aan de bron staan internationale zaadbedrijven zoals, Rijkzwaan, Bejo en Enza Eastwest en Syngenta zaden. Deze bedrijven voorzien telers van zaden voor teelten in de opengrond en in kassen. De zaden worden eerst opgekweekt tot plantgoed en opgekweekt door speciale bedrijven. Ruim 200 bedrijven houden zich bezig met opkweken van gewassen voor in de kas (figuur 2.8). Voor de opengrond is ongeveer het dubbele aantal actief. Gezamenlijk gaat het voor de opkweek om ruim 2.575 ha.

Veredelaars werken aan verbetering van gewassen. Het ontwikkelen van nieuwe rassen is een langdurig proces. Vooral de ontwikkeling van weerbaarheid tegen ziektes, extreme weersomstandigheden of verzilting zijn actuele thema's waar aan gewerkt wordt. Zo wordt momenteel gewerkt aan de ontwikkeling van rassen die resident zijn voor het Tomato Brown Rugose Fruit Virus in de tomatenteelt (NH nieuws, 2021) Ook worden rassen verbeterd met het oog op de consument. Daarbij speelt onder andere smaak een rol en de reductie van voedselverspilling. Zo werd er recentelijk een broccoliras ontwikkeld, dat claimt voedselverspilling tegen te gaan (Seedvalley, 2021). 
Aantal bedrijven stabiel en areaal licht toegenomen

Ongeveer 5.200 bedrijven telen groente en fruit in de open grond. In Nederland waren er in 2020 zo'n 1.250 bedrijven die groenten onder glas telen, daarnaast zijn er 115 bedrijven met fruitteelt onder glas. Spruiten, witte en rode kool, broccoli en asperge zijn belangrijke gewassen (in ha gemeten) in de vollegrondgroenteteelt. Voor fruit zijn dit appels en peren. Het areaal appels daalt de laatste jaren, dat van peren neemt toe.

In kassen zijn tomaten, paprika en komkommers de drie belangrijkste teelten. Bij fruit onder glas gaat het om onder andere bramen en frambozen. Aardbeien is een teelt die zich de laatste jaren sterk heeft ontwikkeld. Voorheen vond deze teelt vooral in de open grond plaats, inmiddels is dit het $4^{\mathrm{e}}$ kasteeltproduct in Nederland. Overigens worden in de CBS-statistieken over bedrijven en arealen aardbeien tot de groenten gerekend. De biologische kasteelt van groenten beperkt zich tot enkele procenten van het totale areaal. Bij opengrondsgroente is dit percentage $11 \%$ à $12 \%$.

Het aantal glasgroentebedrijven in Nederland nam tot 2018 gestaag af, maar lijkt de afgelopen jaren te stabiliseren. Het areaal per bedrijf neemt juist toe, bedrijven worden steeds groter. In de glasgroentesector zijn Agrocare en Combivliet hier voorbeelden van. Deze beide bedrijven telen tomaten op meer dan 100 ha glas. Dergelijke bedrijven hebben diverse locaties in Nederland en ook soms vestigingen in het buitenland. Deze telers hebben ook vergaande samenwerkingen en contacten met verwerking en verpakkingsbedrijven, uitzendorganisaties, verpakking-, verkoop- en inkooporganisaties. Daarnaast bestaan er samenwerkingsvormen op het gebied van het verduurzamen van de energievoorziening zoals geothermie.

Het assortiment groente en fruit dat in Nederland geteeld wordt, is veel breder dan hier boven genoemd. Er wordt ook volop geëxperimenteerd met nieuwe gewassen, waarbij sommige ook tot een volwaardige productie uitgroeien. Zo wordt er, weliswaar op kleine schaal, papaya geteeld in Nederland. Ook behoort watermeloen en vanille inmiddels tot het assortiment.

\section{Afzet wordt op vele manieren georganiseerd}

Het assortiment wordt op verschillende manieren en via diverse kanalen verhandeld. In het fruit is veiling Fruitmasters een belangrijk afzetkanaal voor telers en in mindere mate veiling Zaltbommel. Fruitmasters regelt niet alleen de verkoop maar biedt ook andere service aan kwekers, zoals sorteren en bewaring van fruit. Veel fruitbedrijven verhandelen ook zelf hun gewassen, of besteden delen als sorteren, verpakken en bewaring uit aan collega's.

Groente en fruit wordt ook veel via telersverenigingen verhandeld. Enkele belangrijke spelers zijn hier de Greenery, Qxin Growers en Harvest House, Growers United, Coöperatieve telersvereniging de Schakel en Fossa Eugena. Deze partijen bundelen aanbod en proberen een zo goed mogelijke prijs in de markt te halen voor hun telers. Deze telersverenigingen kunnen samenwerken op het gebied van verpakkingen, raskeuze, investeringen, teelt en onderzoek. Het gebeurt ook dat Nederlandse producenten naar Belgische veilingen uitwijken om hun producten te verkopen.

Naast deze telersverenigingen zijn er ook veel handelsbedrijven actief. In Nederland waren er eind 2019 zo'n 1.315 handelsbedrijven (figuur 2.8) actief, dit aantal neemt wel af. De trend is ook dat grotere handelsbedrijven kleinere overnemen. Overigens zijn de meeste van deze handelsbedrijven vrij klein van omvang. Ongeveer 700 bedrijven zijn eenmanszaken, nog eens 425 bedrijven hebben een personeelsbestand van maximaal 10 mensen. Enkele grote spelers in de handel van groente en fruit zijn Bakker Barendrecht, Levarht \& Zn, Smeding, Valstar, Van der Staay, Van Oers, Vogelaar Vredehof en Witkamp. Ten slotte bestaan er nog veel importbedrijven die Nederlands assortiment combineren met fruitimport.

\section{Import belangrijk voor fruit en aanvullend voor groenten}

In Nederland was de importwaarde van groenten in 2020 2,5 mld. euro, van fruit 7,2 mld. euro (figuur 2.8). De import van groente is kleiner omdat Nederland hier ten dele zelfvoorzienend in is. In de winterperiode worden wel veel groenten (tomaten, paprika's en komkommers) uit Spanje geïmporteerd. Nederland importeert meer fruit dan groente, deels vanuit de EU maar vooral vanuit verder weg gelegen bestemmingen. Het gaat om druiven, avocado's en citrusproducten uit Zuid-Afrika en Peru en andere landen 
in Latijns-Amerika, en om producten als grapefruit en frambozen uit Spanje. Via België komen veel bananen en kiwi's Nederland binnen. Samen met de Nederlandse productie levert deze import een totaal assortiment op dat soms na rijping veelal ook weer geëxporteerd wordt naar de directe buurlanden. Exportbedrijven kunnen zodoende voor de retail en de foodservice in binnen- en buitenland een totaalassortiment aanbieden.

\section{Export groente en fruit een combinatie van binnenlands product en wederuitvoer} In 2020 bedroeg de exportwaarde van groenten en fruit 7 mld. euro (figuur 2.8). De top-4 bestaat uit tomaten, uien, paprika's en komkommers. Ook champignons zijn een belangrijk exportproduct voor Nederland. In fruit gaan de eerder geïmporteerde producten zoals avocado's, druiven en bananen grotendeels naar onze buurlanden. Exporteurs proberen naast het assembleren en transporteren van groente en fruit, samen met de klanten de omzet en marges te verhogen. Categoriemanagement en productontwikkeling zijn veelal onderdeel van de service van deze exporterende bedrijven. Voorbeelden zijn het meedenken over winkelinrichtingen of reclameacties, of nieuwe productcombinaties in voorverpakte productpakketten, salades of gesneden groenten. Sommige bedrijven zoals Hessings, Vezet Tolpoort en van Gelder zijn gespecialiseerd in het verpakken of samenstellen van voorverpakte of gesneden groenten. Langlopende relaties tussen de handel enerzijds en de beperkte inkoopcombinaties van de supermarkten anderzijds zijn gangbaar in deze keten.

\section{Afzet vooral via supermarkten}

In Nederland worden groente en fruit het meeste thuis geconsumeerd, het gaat om ongeveer drievierde deel, de rest wordt buiten de deur gegeten. Van die driekwart wordt verreweg het grootste deel via de supermarkt verkocht aan de consument. Het aandeel van de groenteboer, markthandel en webwinkels is relatief klein. Naast het thuisgedeelte zijn er nog andere kanalen, waarvan de horeca de belangrijkste is. Daarnaast gaat een deel naar de catering en een beperkt deel bestaat uit aankopen zoals food to go. In Nederland zijn er veel afzetpunten voor groente en fruit (figuur 2.8).

\section{Actuele ontwikkelingen in de sector}

De consumptie van groente en fruit in gewicht uitgedrukt steeg in 2020 met zo'n 4\% (GFH, 2021-1). Daarbij was er een sterke groei in het thuisverbruik en een daling bij de out of home kanalen, met name als gevolg van de sluiting van horeca tijdens de lock downs als gevolg van corona. Online aankopen, verspakketten en maaltijdboxen stegen in populariteit (GFH1, 2021). Ook in 2021 zet deze trend door (GFH, 2021-2). De consumptie moet echter nog wel verder stijgen om de dagelijks aanbevolen hoeveelheid te halen, deze is per persoon per dag 200 gram groente en 200 gram fruit. Nederlanders eten gemiddeld echter niet meer dan 130 gram van beide (RIVM, 2021).

Er zijn de afgelopen jaren initiatieven opgezet om klanten te stimuleren om meer groenten en fruit te kopen. Het Nationaal Actieplan Groenten en Fruit (NAGF) wil de consumptie van groenten en fruit verhogen door middel van een experiment naar de potentie van nudges zoals toegangspoortjes, winkelwagen-inlays of een gezond aanbod aan de kassa. Tot op heden zijn de resultaten positief en is geconstateerd dat een combinatie van nudges een positief effect heeft op het koopgedrag van consumenten (NAGF, 2019).

Naast het verhogen van de consumptie is net als in andere sectoren een verdere verduurzaming van de productie en aanverwante ketens een belangrijk aandachtspunt. Zowel teelt als handel werken al veel met gecertificeerde processen, die al dan niet tot aan de consument bekendheid genieten. Zo hebben veel bedrijven als standaard in de keten een Global Gap-certificaat dat de bedrijfsprocessen in kaart brengt en zo inzicht geeft in maatregelen die voedselveiligheid vergroten en duurzaamheidsprestaties in kaart brengt. Een certificaat op het gebied van duurzaamheidseisen is On the way to PlanetProof. Dit certificaat is in opkomst in Nederland en belangrijk voor telers die willen leveren aan binnenlandse afnemers. Langzamerhand is er een veelheid aan labels en certificeringen ontstaan die inzicht moeten bieden in duurzaamheidsprestaties of eerlijke handel. Zo zijn er specifieke certificeringseisen voor bepaalde supermarktketens in verschillende landen.

Ook supermarkten roeren zich. Zo rollen Aldi Sud en Aldi Nord een standaard uit voor de productie van groente en fruit. Voor de 15 meest verkochte artikelen uit risicogebieden, zoals avocado uit Peru en tomaten uit Spanje, aardbeien en appels word een standaard opgelegd (gfactueel, 2021). Een ander initiatief is het Sustainability Initiative Fruit and Vegetables (Sifav). Dit platform streeft naar $100 \%$ duurzame inkoop van 
groente en fruit door haar leden. Het aantal leden was in 2021 gegroeid tot 40 in totaal uit verschillende landen (GFH3, 2021).

Hoewel het even stil is geweest in de verpakkingsdiscussie door corona, gaat de vermindering van verpakkingsmiddelen onverminderd voort. In Frankrijk komt er vanaf 1 januari 2022 een verbod op plastic verpakking voor groente als prei, courgettes, komkommers en paprika's. Voor fruit gaat het plastic verbod gelden voor peren en bananen. Plastic verpakkingen worden nog wel toegestaan voor producten die zijn verpakt in partijen van 1,5 kilo of meer en voor sommige producten is er nog wat uitstel, omdat er voor onder andere kersen, sla en frambozen nog geen plasticvrij alternatief is. Plastic verpakkingen houden groenten langer vers, dit verbod zou dus tot (meer) voedselverspilling kunnen leiden (Retaildetail, 2021). In Nederland zijn supermarkten zoals Lidl, Aldi, Jumbo en Plus ook bezig met het verminderen van de plastic verpakking van groenten en fruit. Ook Albert Heijn geeft aan dat ze in 2025 van alle plastic verpakkingen bij groenten en fruit af wil zijn (AD, 2021).

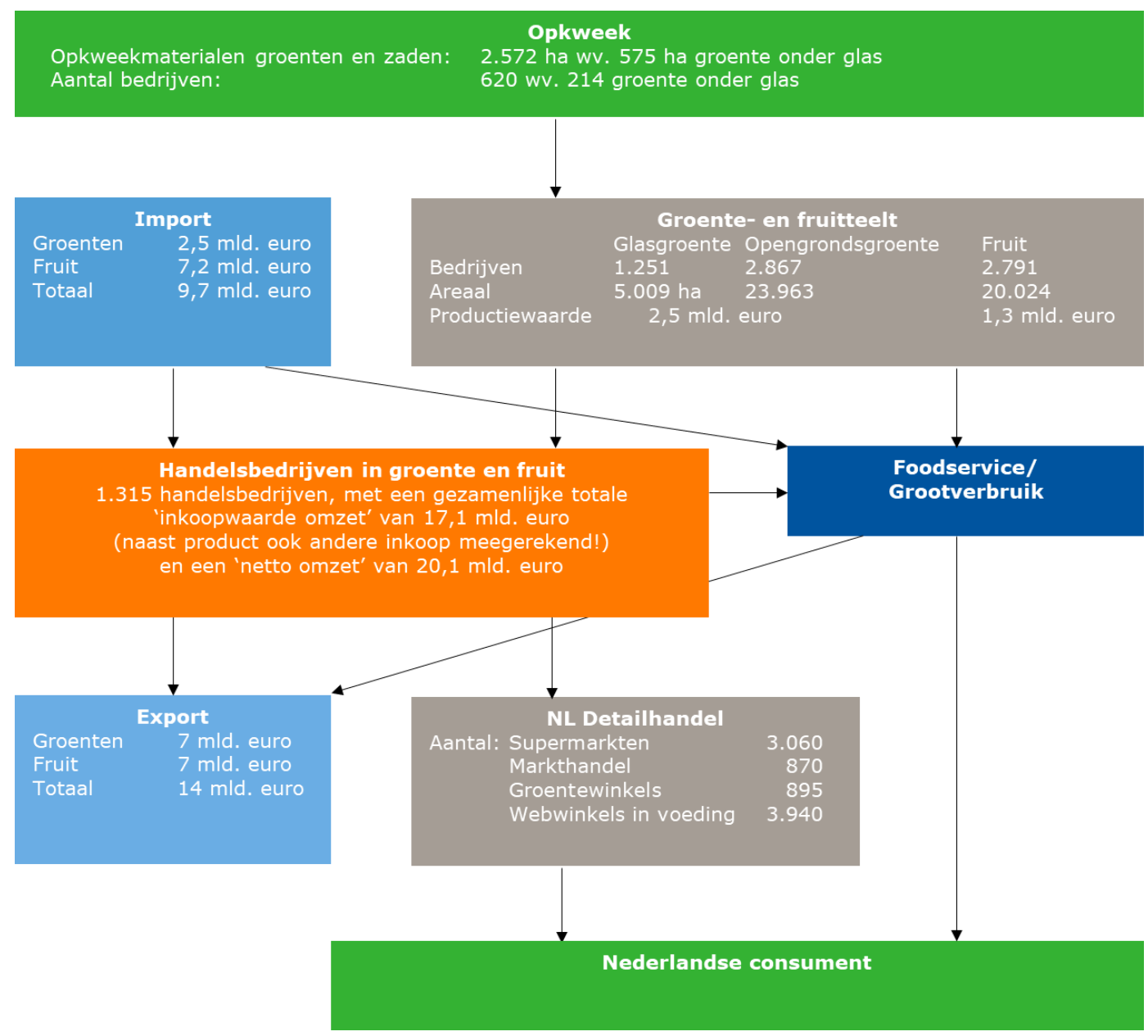

Figuur 2.8 Globaal overzicht van de groenten en fruit keten, 2020 Bron: CBS, Wageningen Economic Research.

\subsubsection{Varkens ${ }^{11}$}

De Nederlandse varkenshouderij kende in 2018 bijna 4.200 bedrijven die gezamenlijk zo'n 24,5 mln. dieren per jaar produceerden. Van de Nederlandse productie zijn $11 \mathrm{mln}$. dieren levend geëxporteerd, de rest werd binnenlands geslacht. Hoewel het aantal bedrijven de laatste decennia sterk afneemt, is het aantal dieren nauwelijks gedaald. Sinds 1998 is in Nederland het totaal aantal varkens begrensd via varkensrechten in plaats van de mestproductierechten (grondgebonden en niet-grondgebonden rechten). Momenteel zijn er ongeveer 8,7 mln. varkensrechten, 27\% minder dan in 1998. Er waren in 2018 in totaal 12,4 mln. varkens

${ }^{11}$ Deze keten is in 2020 voor het laatst geactualiseerd en bevat daarom niet de meest recente ontwikkelingen. 
aanwezig in Nederland, waarvan 923.000 zeugen en 5,6 mln. vleesvarkens, en verder biggen, beren en opfokdieren (figuur 2.9).

\section{Concentratie varkenshouderij in beperkt aantal gebieden}

De varkenshouderij is sterk geconcentreerd in Oost-Brabant en Noord-Limburg. Daarnaast zijn er kleinere concentraties in Overijssel, Oost-Gelderland, de Gelderse Vallei en Westelijk Brabant. Het aantal dieren per bedrijf is in de afgelopen decennia fors gestegen. Gespecialiseerde zeugenbedrijven hebben gemiddeld 770 zeugen; gespecialiseerde vleesvarkens- en gesloten varkensbedrijven hebben circa 2.100 vleesvarkens respectievelijk bijna 2.700 vleesvarkens en 468 zeugen per bedrijf (Landbouwtelling 2018). Voor wat betreft schaalgrootte is de Nederlandse varkenshouderij een middenmoter in Europa. In zeugproductiviteit loopt Nederland achter op Denemarken in de wereldtop.

De Nederlandse varkensproductie maakt deel uit van een (Noordwest-)Europees cluster. De zelfvoorzieningsgraad van varkensvlees in de EU-28 was $113 \%$ in 2018 . Voor Nederland is de zelfvoorzieningsgraad circa $300 \%$, waardoor twee derde van de jaarlijkse vleesproductie moet worden uitgevoerd, binnen of buiten de EU.

\section{Sterke concentratie in de slacht en verwerking}

Circa 90\% van de bijna $16 \mathrm{mln}$. varkensslachtingen in Nederland vindt plaats bij de grootste vier slachtondernemingen. Vion Food Group slacht ongeveer de helft van de varkens in Nederland; de andere grote ondernemingen zijn Van Rooi Meat, Westfort en Compaxo.

De vleesindustrie in (Noordwest-)Europa is met elkaar verweven in afzetkanalen en ontwikkelingen. Er is daardoor stevige concurrentie met de grote spelers zoals Tönnies en Westfleisch in Duitsland, en Danish Crown in Denemarken. Slachterijen hebben vaak ook vestigingen in het buitenland. Nederlandse vleesvarkens worden zowel in Nederlandse slachterijen als in Duitse slachterijen geslacht. Daarnaast worden ook Belgische en Duitse vleesvarkens in Nederlandse slachterijen geslacht.

\section{Veevoermarkt beheerst door drie grote spelers}

De veevoerindustrie in Nederland is grootschalig en internationaal georiënteerd. Er zijn

90 mengvoerfabrieken die in totaal $13,8 \mathrm{mln}$. mengvoer produceren, waarvan 5,1 $\mathrm{mln}$. ton mengvoer voor varkens. De grootste drie bedrijven zijn Agrifirm, ForFarmers en De Heus, met een marktaandeel van circa $60 \%$ van de mengvoerproductie. Nevedi is de koepel van de veevoederindustrie en vertegenwoordigt vrijwe de gehele diervoederindustrie. Veevoerbedrijven kopen grondstoffen over de hele wereld; qua herkomst ligt de nadruk echter op Europa. Inkoop gebeurt veelal via grootschalige handelsbedrijven. Veevoerbedrijven verkopen complete mengvoeders en premixen/concentraten in een groot aantal landen.

Daarnaast handelt een aantal bedrijven in vochtrijke bijproducten van de levensmiddelenindustrie, uit de verwerking van bijvoorbeeld aardappelen, bier, granen, citrusvruchten en plantaardige oliën. Deels komen deze producten in het mengvoer, deels ook als losse grondstoffen bij de veehouders. Vochtrijke bijproducten uit de levensmiddelenindustrie vervangen circa 10\% (droge stofbasis) van het mengvoer. Voor de varkenshouderij zijn de belangrijkste bijproducten tarwezetmeel, aardappelstoomschillen, zuivelproducten en tarwegistconcentraten. De varkenssector draagt hierdoor bij aan de benutting van waardevolle restproducten, het sluiten van kringlopen en de circulaire economie.

Alle soja die de Nederlandse diervoederindustrie gebruikt, is sinds 2015 gegarandeerd van een duurzame teelt afkomstig. Daarnaast zorgen de leden van Nevedi ervoor dat alle palmolie, die gebruikt wordt voor de Nederlandse consumptie, duurzaam is volgens de regels van de Roundtable on Sustainable Palm Oil (Nevedi, 2020). Het sojagehalte in varkensvoer bedraagt circa $8 \%$ (exclusief hullen) (Hoste, 2014).

\section{Hogere productie}

In 2018 produceerde de Nederlandse varkenshouderijsector ruim 1,54 mln. ton karkasgewicht met 15,9 mln. slachtingen. De productie van varkensvlees was in 2018 circa $18 \%$ hoger dan in 2005 door $11 \%$ meer slachtingen en een $7 \%$ hoger slachtgewicht per dier. 
De autonome productiviteitsontwikkeling van de zeugen leidt tot een hogere biggenproductie, die in toenemende mate over de grens wordt afgezet. Van de totale productie van bijna 25 mln. dieren, worden $11 \mathrm{mln}$. dieren geëxporteerd. Vanuit oogpunt van milieudruk, arbeidsprestatie en investeringsbehoefte zou een verdere ontwikkeling van de Nederlandse varkenssector naar een kraamkamer voor andere landen in Europa mogelijk zijn. Veel Midden- en Oost-Europese landen hebben voldoende milieugebruiksruimte (land, grondstoffenteelt voor veevoer), goedkopere huisvesting en lagere lonen.

\section{Lagere consumptie per inwoner}

In 2018 was $629 \mathrm{mln}$. kg varkensvlees beschikbaar voor consumptie in Nederland. Dat is 3,6\% meer dan in 2005 en die stijging is geheel te danken aan de groei van de bevolking met 5,4\% tot 17,2 mln. inwoners, want de consumptie per inwoner vertoont een licht dalende lijn. In Nederland is in 2018 per hoofd van de bevolking $36,6 \mathrm{~kg}$ varkensvlees per jaar geconsumeerd tegen $37,2 \mathrm{~kg}$ in 2005 . Van de vleesconsumptie in Nederland is $47 \%$ varkensvlees (Dagevos et al., 2019).

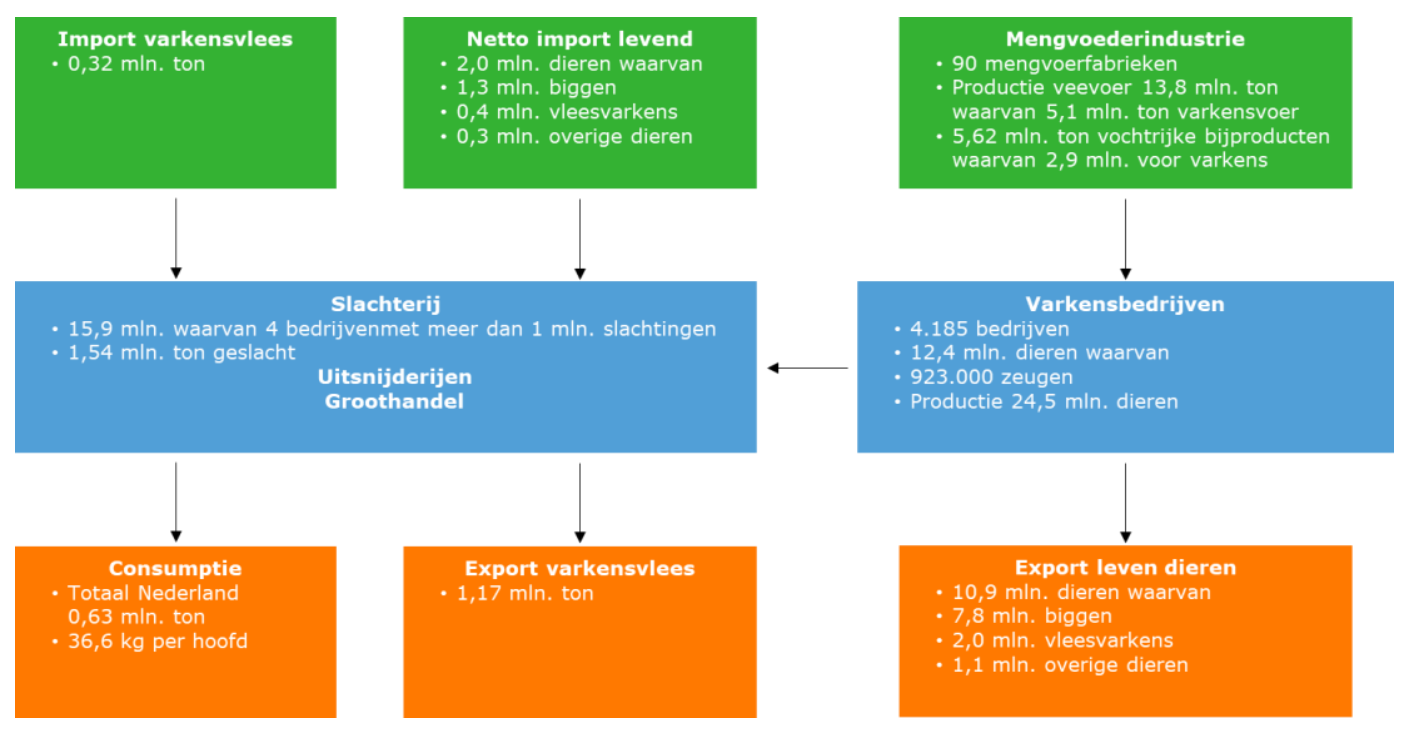

Figuur 2.9 Globaal overzicht van de varkensproductieketen in 2018 Bron: CBS, FEFAC, OPNV, bewerking Wageningen Economic Research.

\section{Export toegenomen}

Twee derde van de Nederlandse varkensproductie wordt geëxporteerd. De export bestaat in 2018 voor het grootste deel uit vlees $(1,17 \mathrm{mln}$. ton), maar ook uit levende dieren. Het gaat daarbij om 7,8 mln. biggen en $2 \mathrm{mln}$. vleesvarkens. Omdat de productie sneller is gegroeid dan de binnenlandse consumptie, moet meer varkensvlees worden uitgevoerd. Vergeleken met 2005 is de uitvoer van varkensvlees met $30 \%$ toegenomen. De export van levende dieren is in 2018 bijna 80\% hoger dan in 2005, maar die groei werd al in de periode 2005-2010 gerealiseerd. Daarna schommelde het aantal levend uitgevoerde dieren tussen 8 en $11 \mathrm{mln}$. stuks per jaar.

De meeste export van levende dieren en vlees gaat naar landen binnen de EU. Duitsland is een belangrijke bestemming, met circa 65\% van de biggenexport en bijna 100\% van de vleesvarkensexport. Sinds 2016 is de export van varkensvlees en -producten vanuit de EU naar vooral China fors toegenomen onder invloed van een sterke vraag. Vanaf 2019 is de importbehoefte van China nog groter geworden omdat circa de helft van varkensstapel is geslacht door uitbraak van de Afrikaanse varkenspest. In 2019 werd China daardoor de belangrijkste exportmarkt. In 2018 was China nog het vijfde exportland voor Nederland. Naast deze grote export is er in mindere mate ook import van zowel vlees als levende dieren uit de buurlanden en dan vooral de aangrenzende regio's in Duitsland en België.

Verduurzaming van de productie via kwaliteitssystemen, keurmerken en marktconcepten Bijna alle varkenshouders nemen deel aan één van de twee kwaliteitssystemen in de varkenshouderij: IKB Varkens en IKB Nederland. Deze IKB-systemen werken samen in het Ketenbreed Kwaliteitssysteem (KKS 
Holland Varken) en het Ketenbreed Informatiesysteem (KIS Holland Varken) (POV, 2020). Deze

kwaliteitssystemen geven garanties dat er minimaal voldaan wordt aan de wettelijke eisen rond productie en productveiligheid. Daarnaast zijn er bijvoorbeeld op het gebied van diergezondheid ook bovenwettelijke eisen gesteld.

Het keurmerk Beter Leven, geïntroduceerd door de Dierenbescherming in 2007, geeft consumenten inzicht in het niveau van dierenwelzijn bij varkensbedrijven. Voor dit keurmerk zijn met bedrijven bovenwettelijke afspraken gemaakt over dierenwelzijn. Bij een product met één ster hebben dieren meer ruimte, worden ze in grote groepen gehouden en is castratie verboden. Bij een tweede ster gaat het grofweg om 'scharrel met een uitloop naar buiten' en bij de derde ster sluiten de houderij-omstandigheden nog beter aan op de behoeften van het dier; drie sterren komt overeen met de biologische sector (Dierenbescherming, 2020).

Om tegemoet te komen aan de groeiende wens van de consument wat betreft duurzaamheid en dierenwelzijn hebben de supermarkten (verenigd in het Centraal Bureau Levensmiddelenhandel, CBL) afspraken gemaakt met Land- en Tuinbouworganisatie Nederland (LTO) en de Centrale Organisatie voor de Vleessector (COV) om het gangbare vlees verder te verduurzamen. De verkoop van vers varkensvlees via supermarkten voldoet minimaal aan de eisen van het programma Varken van Morgen. De welzijnseisen voor de productie binnen dit programma zijn vergelijkbaar met de eisen met 1 ster van het Beter Leven keurmerk.

Er worden naar schatting $4 \mathrm{mln}$. tot $5 \mathrm{mln}$. varkens per jaar met 1 ster en/of Varken van Morgen geproduceerd. Anno 2019 zijn er slechts een paar bedrijven met het predicaat Scharrel (2 sterren) en er worden naar schatting 130.000 biologische slachtvarkens per jaar (3 sterren) geproduceerd. Afgezet tegen de totale productie van $24,5 \mathrm{mln}$. dieren zijn dat marktaandelen van $15-20 \% 1$ ster (Varken van Morgen), $0 \%$ ( 2 sterren) en $0,5 \%$ (bio). De rest van de afzet is vlees dat geproduceerd is volgens de wettelijke minimumeisen.

\subsubsection{Pluimvee ${ }^{12}$}

In 2019 werden op circa 1.900 pluimveebedrijven in totaal $102 \mathrm{mln}$. kippen gehouden. Het pluimveecomplex biedt werkgelegenheid aan 20.600 personen in 2018. Pluimveevlees wordt geproduceerd door meerdere soorten pluimvee op de primaire bedrijven. Veruit het belangrijkste zijn de vleeskuikens, op ruime afstand gevolgd door kalkoenen en eenden. Deze bijdrage beschrijft de keten rondom vleeskuikens.

De productieketen van pluimveevlees kent meerdere opeenvolgende schakels, die elk een gespecialiseerde taak voor hun rekening nemen. De keten is een samenspel van specialismen waarin fokkerij, vermeerderaar, broederij, pluimveehouder en slachter/verwerker samenwerken. Figuur 2.10 geeft de hoofdlijnen van de keten. Bovenin staan de vermeerderingsbedrijven die broedeieren produceren. Op 180 bedrijven worden 4,7 mln. ouderdieren gehouden die 900 tot $950 \mathrm{mln}$. broedeieren produceren per jaar. In de kuikenbroederijen (14 bedrijven) worden de broedeieren uitgebroed tot eendagskuikens. Daarna worden de eendagskuikens afgeleverd bij de vleeskuikenhouders. Op 640 bedrijven worden jaarlijks $360 \mathrm{mln}$. eendagskuikens opgezet. De vleeskuikens worden gehouden tot een gewicht van 1,8 tot 2,8 kg (gemiddeld $2,4 \mathrm{~kg}$ ) om vervolgens getransporteerd te worden naar een pluimveeslachterij. In Nederland produceren 16 slachterijen jaarlijks ruim $1 \mathrm{mln}$. ton kip (geslacht gewicht).

\section{Export in alle schakels}

In bijna elke schakel is export belangrijk. Voor de broederijen en exporteurs van broedeieren bedraagt de netto-export (export minus import) van broedeieren circa een derde van de totale productie. Hierbij is Rusland veruit de belangrijkste bestemming met een aandeel van meer dan $80 \%$. De Nederlandse broederijen exporteren ook een deel van de eendagskuikens. Van het totaal aantal eendagskuikens gaan $360 \mathrm{mln}$. kuikens naar de Nederlandse vleeskuikenhouders en circa $150 \mathrm{mln}$. kuikens worden geëxporteerd. Hierbij is Duitsland veruit de belangrijkste bestemming. Ook voor de slachterijen en uitsnijderijen is export belangrijk. Verse kipdelen (kipfilet) worden geëxporteerd naar Duitsland en het Verenigd Koninkrijk, voor bevroren producten (poten en bouten) zijn landen in Afrika en Azië belangrijke bestemmingen.

12 Deze keten is in 2020 voor het laatst geactualiseerd en bevat daarom niet de meest recente ontwikkelingen. 


\section{Concepten met strengere normen in de supermarkt}

Een belangrijke ontwikkeling in de pluimveevleessector is de opkomst van de zogenoemde concepten. Concepten is de verzamelnaam voor alle houderijsystemen waar vleeskuikens gehouden worden volgens strengere normen voor dierenwelzijn dan wettelijk vereist is. Zo wordt sinds 2007 naast reguliere en biologische kip, ook scharrelpluimveevlees geproduceerd en verkocht in Nederland. Dit vlees wordt geproduceerd volgens de regels van het Beter Leven keurmerk (1 ster): kuikens van een langzaam groeiend ras, met meer ruimte, daglicht en toegang tot een overdekte uitloop. De productie en consumptie van pluimveevlees dat is geproduceerd via een concept is de laatste jaren gestaag toegenomen, het aandeel in de supermarkt van de Beter Leven kip was in 2018 circa 15\% (aandeel van gewicht, in waarde is het aandeel 20\%) (Logatcheva, 2019).

In 2015 zijn door de supermarkten nieuwe concepten geïntroduceerd. Het gaat om pluimveevlees van vleeskuikens die gehouden worden volgens specifieke regels met betrekking tot groeisnelheid, bezetting, daglicht en verrijking in de stal (zoals strobalen en graan bijstrooien). Elke supermarktketen heeft een eigen concept, waarvan de nieuwe standaardkip (NSK) van Jumbo en de Goed Nest Kip (GNK), verkocht als de nieuwe Albert Heijn kip, de bekendste zijn. Doordat alle grote supermarktketens de verkoop van de reguliere kip gestaakt hebben, was er in 2019 uitsluitend aanbod van pluimveevlees van langzaam groeiende vleeskuikens in de vorm van het eigen concept van de supermarkt, Beter Leven kip of biologische kip. Dit aanbod heeft betrekking op het vers-segment in de Nederlandse supermarkt. Buiten de supermarkt en ook in het diepvriessegment van de supermarkt is er nog aanbod van regulier kipvlees.

Door de veranderende vraag zijn veel vleeskuikenhouders overgegaan tot het houden van langzaam groeiende kip. Van de $360 \mathrm{mln}$. eendagskuikens opgezet op de Nederlandse vleeskuikenbedrijven (zie figuur 2.10) was in $201930 \%$ van een langzaam groeiend ras (Avined, 2020). De overige $70 \%$ van de kuikens is van een snel groeiend ras. Dit pluimveevlees is voor de foodservice (restaurants, catering, instellingen) en de export (vooral Duitsland en het Verenigd Koninkrijk). Verder terug in de keten gaan ook vermeerderaars ouderdieren houden van langzaam groeiende rassen. In 2019 was 11\% van de ouderdieren van een langzaam groeiend ras (Avined, 2020).

\section{Veel integraal duurzame pluimveestallen}

In de vleeskuikensector wordt volop geïnvesteerd. In de markt van scharrelkuikens (Beter Leven 1 ster) hebben bestaande landbouwbedrijven (bijvoorbeeld akkerbouw of melkveebedrijven) veelal als neventak een vleeskuikenstal gebouwd. In de statistieken zien we het aantal bedrijven met vleeskuikens dan ook toenemen. ${ }^{13}$ Ook bestaande vleeskuikenbedrijven bouwen regelmatig een nieuwe stal of vervangen oudere stallen. Daarnaast zijn er vleeskuikenbedrijven die een overdekte uitloop aan de stal geplaatst hebben om zo te voldoen aan het Beter Leven keurmerk. Veel nieuwbouwstallen voldoen aan de maatlat duurzame veehouderij (MDV). Het voorgaande betekent dat het aantal integraal duurzame stallen de laatste jaren gestaag is toegenomen. In een integraal duurzame stal worden verschillende duurzaamheidskenmerken, zoals dierenwelzijn, milieu, diergezondheid en arbeidsomstandigheden, in onderlinge samenhang verbeterd ten opzichte van reguliere stallen. Volgens de monitoring integraal duurzame stallen (Van der Peet et al., 2020) was in 2019 meer dan de helft van de stallen in de pluimveehouderij integraal duurzaam. Van de integraal duurzame stallen voldoen de meeste aan de eisen van de Maatlat Duurzame Veehouderij en Beter Leven keurmerk. Ook biologische stallen vallen onder de noemer integraal duurzame stal. Een kleiner deel van de stallen heeft gebruikgemaakt van de investeringsregeling Integraal Duurzame stal- en houderijsystemen (EZ subsidies RLS).

\section{Antibiotica gebruik fors gedaald}

De pluimveesector heeft enkele jaren geleden een Convenant antibioticaresistentie dierhouderij ondertekend om het gebruik van antibiotica te verminderen. Een afname van het gebruik van antibiotica moet zorgen voor vermindering van resistente bacteriën bij vleeskuikens en op pluimveevlees. Het gebruik van antibiotica wordt uitgedrukt in dierdagdoseringen per jaar (ddd/jaar). Tussen 2009 en 2019 is het gebruik van antibiotica met 70\% afgenomen (Avined, 2020). Hiermee is de doelstelling van $70 \%$ reductie in 2020 gehaald. Sinds 2014 worden door een deel van de vleeskuikenhouders langzaam groeiende kuikens gehouden. Het antibioticagebruik bij deze dieren is zeer laag. In 2019 was het gebruik bij reguliere kuikens $13 \mathrm{ddd} /$ jaar en bij langzaam groeiende kuikens 4 ddd/jaar. Omdat circa 35\% van de kuikens van een

\footnotetext{
${ }^{13}$ www.agrimatie.nl
} 
langzaam groeiend ras was, is het gemiddelde voor Nederland circa $10 \mathrm{ddd} / \mathrm{jaar}$. Alle Nederlandse supermarkten verkopen in het vers-segment uitsluitend pluimveevlees van langzaam groeiende kuikens. De reguliere kuikens worden gehouden voor de foodservice (restaurants en catering) en voor de export.

\section{Import uit Oekraïne blijft toenemen}

De pluimveevleessector wordt gekenmerkt door enerzijds een grote export en anderzijds een grote import van pluimveevlees. De export is vooral gericht op afzet van hoogwaardige kipfilet naar de omringende landen. Daarnaast is er een substantiële import van kuikenvlees (vooral bevroren kipfilet) uit Brazilië, Thailand en Oekraïne. Dit vlees vindt vooral zijn bestemming naar de foodservice en de verwerkende industrie. De EU is in overleg met een aantal landen om via bilaterale handelsakkoorden te komen tot meer vrijhandel. Er is een handelsakkoord afgesloten met Oekraïne, Canada en Japan en er is overleg gaande met onder Mercosur (een economisch samenwerkingsverband tussen Argentinië, Brazilië, Paraguay en Uruguay).

De Europese pluimveevleessector kan niet concurreren op kostprijs met lagekostenlanden zoals de Verenigde Staten, Brazilië en Oekraïne (Van Horne, 2018). De bedrijven in de landen buiten de EU hebben voordelen van goedkoop veevoer (lokaal aanbod van grondstoffen mais, tarwe en soja), schaalvoordelen (grote bedrijven) en goedkope arbeid. Daarnaast is er amper wet- en regelgeving voor dierenwelzijn, milieu en voedselveiligheid zoals de Europese bedrijven die kennen. Deze verschillen leiden tot concurrentievoordelen en zijn deels terug te voeren op maatschappelijke voorkeuren die zich vertalen in meer of minder strenge regelgeving. Vooral de toegenomen import uit Oekraïne geeft zorgen in de sector. Bijkomend probleem is dat Oekraïne de mogelijkheid heeft om vers pluimveevlees aan te bieden in bijvoorbeeld Polen, Duitsland en Nederland omdat de afstand relatief klein is. Dit is het grote verschil met de traditionele aanbieders Brazilië en Thailand, die alleen bevroren pluimveevlees kunnen aanbieden.

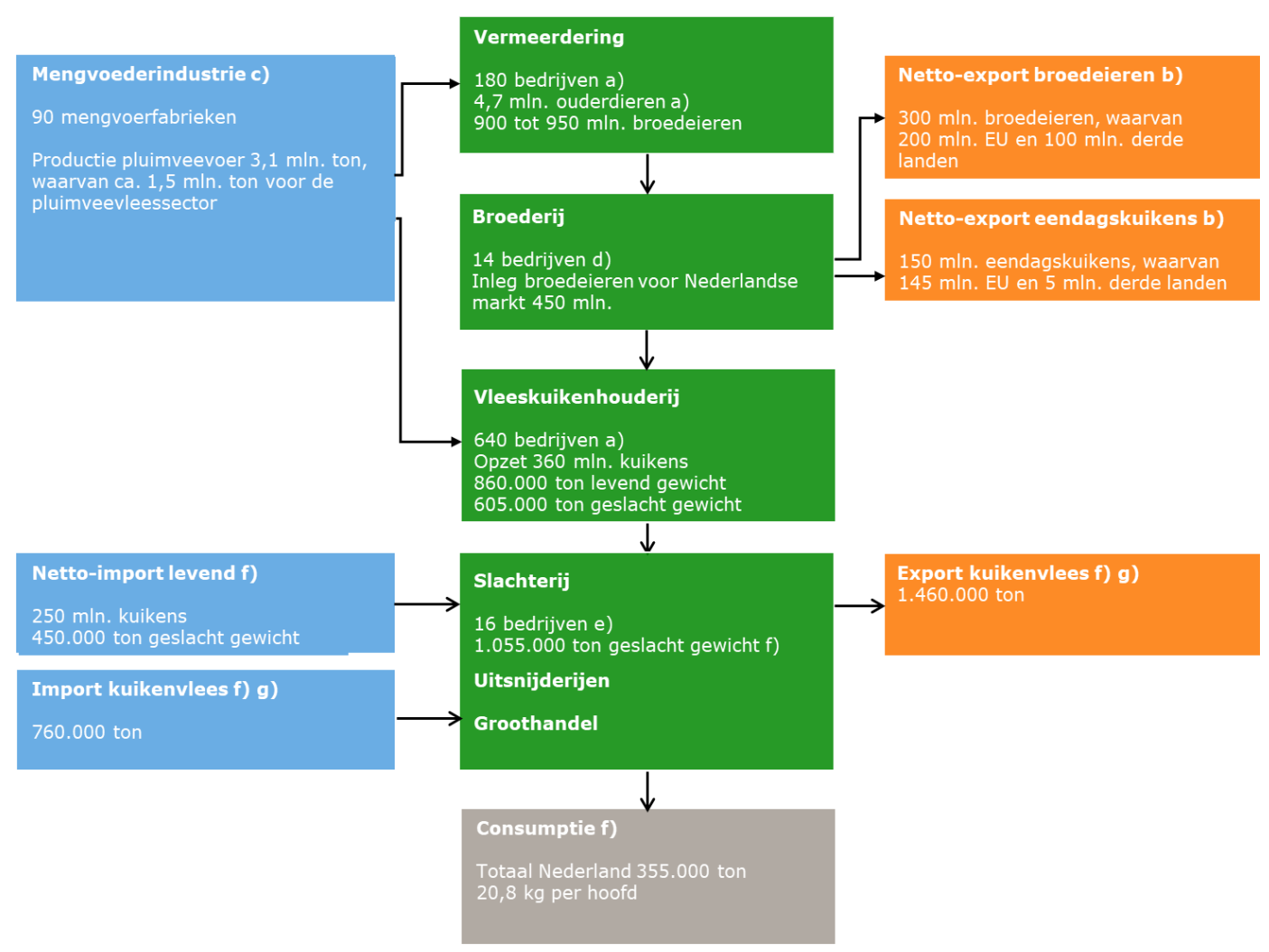

Figuur 2.10 Globaal overzicht van de keten rond de vleeskuikenhouderij, 2018 


\subsection{8 $\quad$ Eieren $^{14}$}

De productieketen van eieren kent meerdere opeenvolgende schakels, die elk een gespecialiseerde taak voor hun rekening nemen. De keten is een samenspel van specialismen waarin fokkerij, vermeerderaar, broederij, leghennenhouder en pakstation/eiproductenfabrikant samenwerken. Figuur 2.11 geeft de hoofdlijnen van de keten. Bovenin staan de bedrijven met ouderdieren die broedeieren produceren. In de kuikenbroederijen worden de broedeieren uitgebroed tot eendagskuikens. Via gespecialiseerde opfokbedrijven komen de opfokhennen bij de leghennenhouders. In 2018 waren er in Nederland 830 bedrijven met leghennen waar ruim $35 \mathrm{mln}$. leghennen in totaal $10.200 \mathrm{mln}$. consumptie-eieren produceerden. De eieren worden vervolgens geleverd aan eierpakstations en fabrikanten van eiproducten.

\section{Export is belangrijk}

In bijna elke schakel is export belangrijk. Broederijen exporteren broedeieren en eendagskuikens, met name naar de omringende landen. Ook een deel van de opfokhennen wordt verkocht in de buurlanden. Pakstations zijn een belangrijk verzamelpunt voor de handel in eieren. Bij de pakstations werden in 2018 ruim $10.000 \mathrm{mln}$. eieren verzameld. Vanuit de pakstations is er export van consumptie-eieren (6.700 mln. eieren) naar vooral Duitsland (80\%), overige EU-landen (15\%) en naar derde landen (5\%). De import van consumptie-eieren ( $2.750 \mathrm{mln}$. eieren) komt vooral uit Duitsland, België en Polen. De eiproductenfabrikanten importeren en exporteren eiproducten. Vloeibaar eiproduct wordt vooral verhandeld binnen de EU. Gedroogd eiproduct wordt verhandeld over langere afstanden; er is invoer uit de Verenigde Staten en Oekraïne en export naar onder andere Japan.

\section{Merendeel hennen in scharrelsysteem}

Sinds 2012 is de houderij van hennen in traditionele kooihuisvesting verboden. Al voor het ingaan van dit verbod hebben veel Nederlandse leghennenhouders de omslag gemaakt naar alternatieve houderijsystemen. In 2019 was de verdeling van het aantal hennen per houderijsysteem als volgt: 10\% van de hennen in verrijkte kooi-/koloniehuisvesting, $61 \%$ scharrelhennen (binnen gehouden), $21 \%$ scharrelhennen met vrije uitloop en $8 \%$ biologische hennen (Avined, 2020a). Het aandeel hennen in systemen met een buitenuitloop is de laatste jaren gestaag gestegen. Het aandeel hennen gehouden in kooihuisvesting (nu 10\%) zal het komende jaar fors dalen. Op 1 januari 2021 is namelijk de houderij van hennen in verrijkte kooien (EUregelgeving) niet meer toegestaan en is uitsluitend koloniehuisvesting (grote verrijkte kooi volgens Nederlandse regelgeving) nog toegestaan.

\section{Beter Leven keurmerk in de Nederlandse supermarkt}

Van de totale Nederlandse eierproductie wordt circa 1/3 afgezet binnen Nederland. Consumptie-eieren worden vooral verkocht via de supermarkten. Er zijn geen exacte cijfers bekend van de marktaandelen voor de verschillende soorten eieren. Geschat wordt dat scharreleieren een aandeel hebben van 70 tot $75 \%$. De overige eieren betreffen vrije uitloop en biologische eieren. Kooi-eieren worden niet aangeboden in de supermarkt. Er is afzet in kleine aantallen via weekmarkten of verkoop op de boerderij.

In 2018 en 2019 zijn veel supermarkten gestart met de verkoop van eieren met het Beter Leven keurmerk. Dit keurmerk geeft inzicht in de diervriendelijkheid van de productie: hoe meer sterren hoe hoger het niveau van dierenwelzijn. Nederlandse supermarkten vervangen de binnen gehouden scharreleieren door eieren met een Beter Leven keurmerk met 1 ster, de vrije-uitloopeieren hebben een Beter Leven keurmerk met 2 sterren.

Eind 2019 verkochten bijna alle supermarkten uitsluitend eieren met een Beter Leven keurmerk. De eieren met Beter Leven keurmerk 1 ster zijn dan geproduceerd in stallen met een overdekte uitloop; de eieren met Beter Leven keurmerk 2 sterren komen van bedrijven met een overdekte uitloop, met ook een vrije buitenuitloop met beschutting voor de hennen in de vorm van bomen, struiken of schuiltafels. Biologische eieren en eieren geproduceerd in de stalsystemen Rondeel en Kipster hebben een Beter Leven keurmerk met 3 sterren. Bij de internationale afzet spelen Beter Leven keurmerk sterren (nog) geen rol.

\footnotetext{
${ }^{14}$ Deze keten is in 2020 voor het laatst geactualiseerd en bevat daarom niet de meest recente ontwikkelingen.
} 
De Duitse markt stelt veel extra eisen

Meer dan de helft van de eieren geproduceerd in Nederland wordt geëxporteerd naar Duitsland. Het merendeel van deze eieren wordt verkocht in Duitse supermarkten. De Duitse markt stelt zeer hoge eisen waaraan de Nederlandse eieren moeten voldoen. Dit zijn eisen op het gebied van dierenwelzijn, milieu en voedselveiligheid. Omdat de Duitse supermarkten alleen eieren verkopen met het KAT-keurmerk ('Kontrollierte Alternative Tierhaltungsformen') moeten Nederlandse leghennenhouders die leveren aan de Duitse markt voldoen aan de KAT-eisen. KAT heeft een lange lijst met specifieke bovenwettelijke eisen aan de houderij van leghennen. Zo zijn er extra eisen voor een overdekte uitloop, een maximale dierbezetting en daglicht in stallen. Ook is het behandelen van snavels niet toegestaan. De Duitse supermarkt stelt ook het gebruik van legvoer dat vrij is van genetisch gemodificeerde organismen (non-GMO-voer) als eis. Van meer recente datum is de wens van enkele Duitse supermarkten om de leghaantjes (de broeders van de leghennen) na uitkomst niet als eendagskuiken in de broederij te doden. De broederij moet dan de hennen en hanen scheiden tijdens het broedproces (en zo voorkomen dat er haantje geboren worden) of de haantjes opfokken voor de productie van vlees. Beide varianten geven fors hogere kosten voor de broederij, waardoor de kostprijs van eieren verhoogd wordt.

\section{Concurrentie}

De Europese eiersector kan niet concurreren op kostprijs met lagekostenlanden zoals de Verenigde Staten, Argentinië, India en Oekraïne (Van Horne, 2019). De bedrijven in deze landen buiten de EU hebben voordelen van goedkoop veevoer (lokaal aanbod van grondstoffen als mais, tarwe en soja), schaalvoordelen (grote bedrijven) en goedkope arbeid. Daarnaast is er amper wet- en regelgeving voor dierenwelzijn, milieu en voedselveiligheid zoals die voor Europese bedrijven gelden. Deze verschillen leiden tot concurrentievoordelen en zijn deels terug te voeren op maatschappelijke voorkeuren die zich vertalen in meer of minder strenge regelgeving. Vooral de toegenomen import uit Oekraïne geeft zorgen in de sector. Dat in Oekraïne leghennen nog gehouden worden in traditionele kooihuisvesting met een hoge bezetting (dus een kleine leefoppervlakte per hen) illustreert dat er zeker geen gelijk speelveld is. Oekraïne is een buurland van de EU met relatief korte afstanden tot de Europese markt. Daar komt bij dat in 2014 een handelsverdrag is afgesloten met de EU, waardoor Oekraïne eieren en eiproducten kan exporteren zonder importheffingen. Wel is er een maximum gesteld aan de invoer via zogenaamde contingenten. Het merendeel van de invoer uit Oekraïne is bestemd voor de verwerkende industrie. 


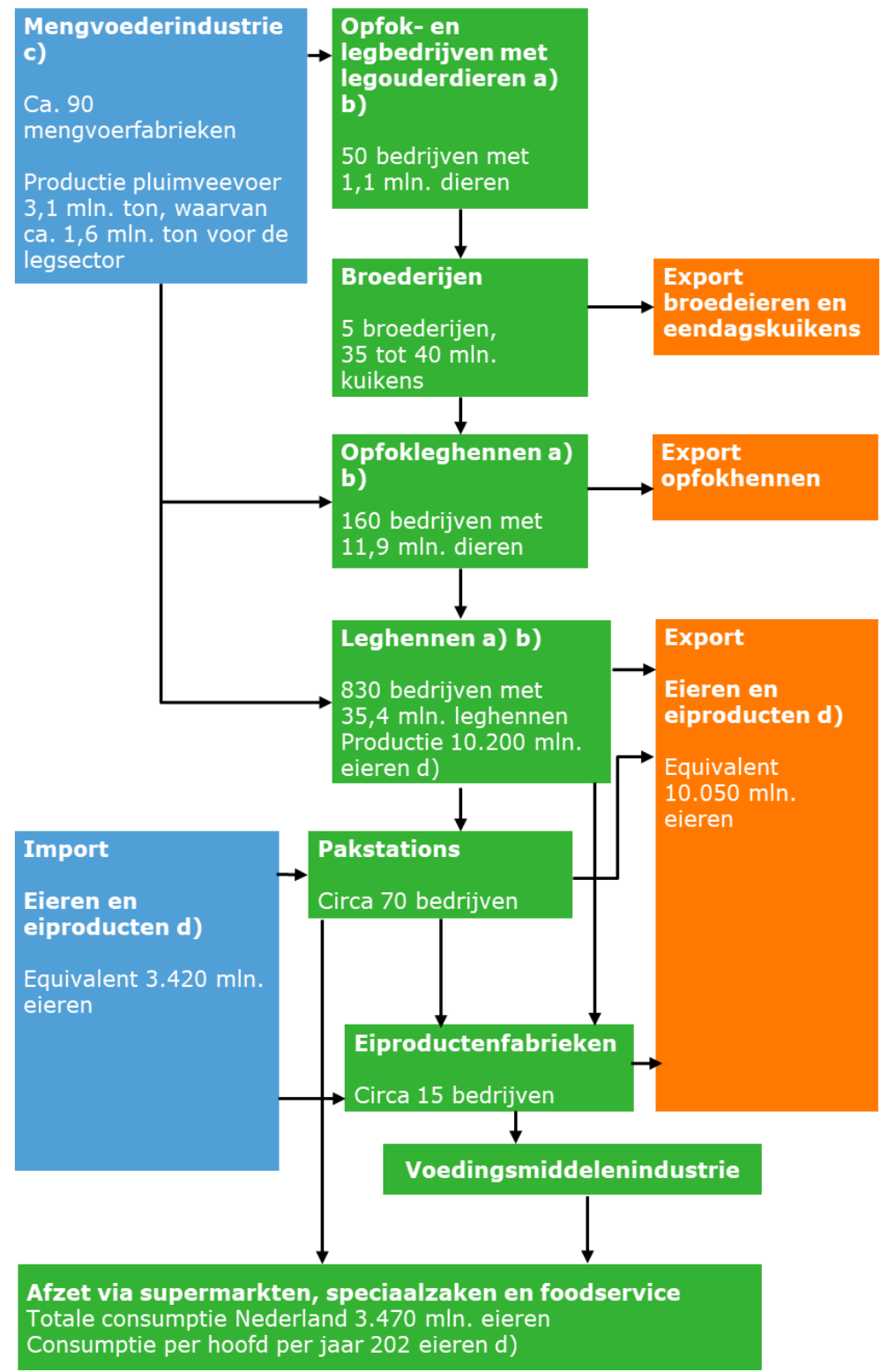

Figuur 2.11 Globaal overzicht van de eierketen, 2018

\subsubsection{Zuivel ${ }^{15}$}

De zuivelketen - het geheel aan bedrijven dat betrokken is bij de productie en verwerking van melk - is het grootste onderdeel van de Nederlandse agrosector in termen van toegevoegde waarde en werkgelegenheid (op basis van binnenlandse grondstoffen). De melkproductie is jarenlang begrensd geweest door de melkquotering. De afschaffing hiervan in 2015 leidde tot een stijging van de melkproductie tot ruim 14,5 mld. kg melk in 2016, waarmee het record van het jaar daarvoor werd verbroken (+7\%). Door de sterke toename van de melkveestapel in 2015 en 2016 kwam de fosfaatproductie in deze jaren ruim boven het sectorplafond van $84,9 \mathrm{mln}$. $\mathrm{kg}$ fosfaat uit. Om de derogatie te behouden noodzaakte dit tot het fosfaatproductiereductieplan en de invoering van fosfaatrechten, waardoor de fosfaatproductie is teruggebracht tot onder de $80 \mathrm{mln}$. kg fosfaat.

Het fosfaatreductieplan in 2017 en de introductie van fosfaatrechten in 2018 hebben geleid tot een daling van de melkproductie naar 14,1 mld. $\mathrm{kg}$ in 2018. Het aantal melk- en kalfkoeien daalde tussen 2016 en 2018 relatief veel meer van 1,75 mln. naar 1,58 mln., maar tegelijkertijd ging de melkgift per koe $500 \mathrm{~kg}$ omhoog.

\footnotetext{
${ }^{15}$ Deze keten is in 2020 voor het laatst geactualiseerd en bevat daarom niet de meest recente ontwikkelingen.
} 
Het aantal melkveehouders nam volgens het CBS verder af: van iets minder dan 18.000 bedrijven in 2016 naar net geen 17.000 bedrijven in 2018 (figuur 2.12). De gemiddelde melkproductie per bedrijf bereikte een volume van $835.000 \mathrm{~kg}$. Dit was $25.000 \mathrm{~kg}$ meer dan in $2016(+3 \%)$. Het aantal melkveehouders met meer dan 150 melkkoeien op het bedrijf daalde tussen 2016 en 2018 licht van 2.400 naar 2.200. Nagenoeg alle melk wordt afgeleverd aan de zuivelindustrie; een klein deel wordt achtergehouden op boerderijen en daar verwerkt (circa $200 \mathrm{mln}$. kg). Er vindt nauwelijks import van rauwe melk plaats.

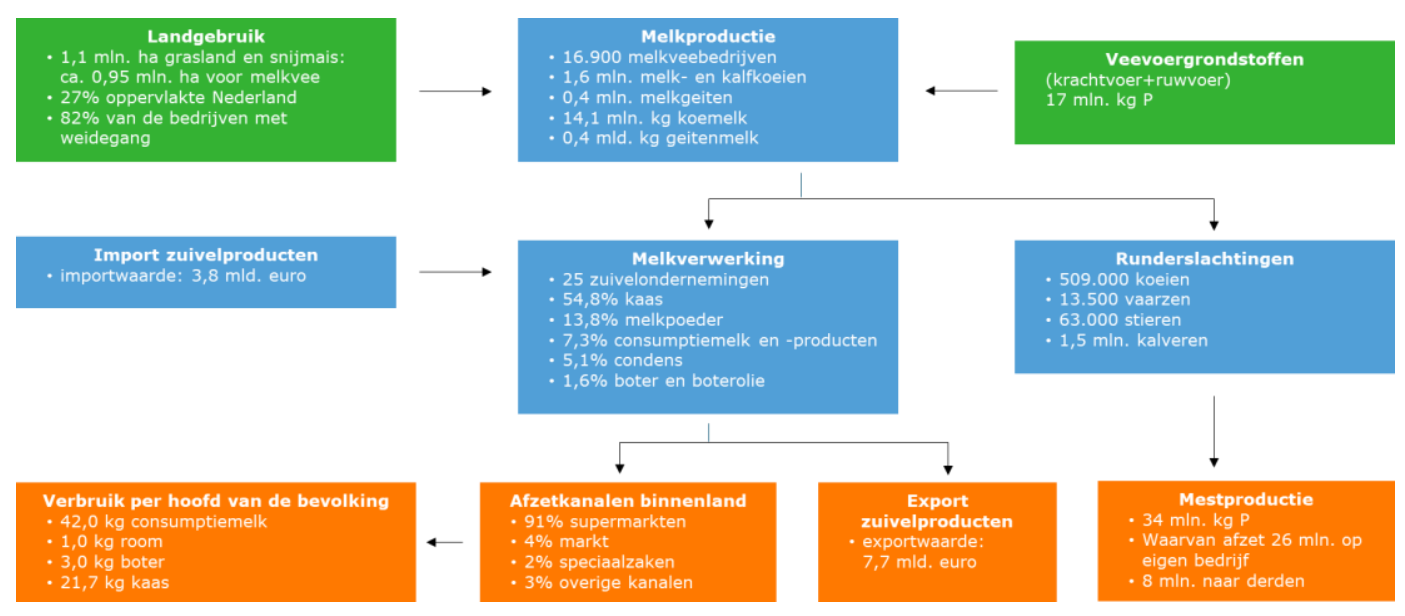

Figuur 2.12 Globaal overzicht van de zuivelketen, 2018

Bron: ZuivelNL, Zuivel in cijfers 2018; bewerking Wageningen Economic Research.

\section{Melkverwerking}

Eind 2018 telde de Nederlandse zuivelindustrie 25 ondernemingen met in totaal 53 productielocaties. Vijf van de ondernemingen zijn coöperaties, die over 27 fabrieken beschikken. Ongeveer $90 \%$ van de gecollecteerde melk wordt verwerkt door coöperaties. Meer dan de helft van de rauwe melk wordt verwerkt in kaas. De sector is internationaal georiënteerd: ruim $65 \%$ van de Nederlandse melkproductie wordt in een groot scala aan producten geëxporteerd. Een derde van de export is bestemd voor markten buiten de EU. Op de lijst van grootste zuivelconcerns in de wereld bezet Friesland-Campina de zesde plaats met een omzet van 12,0 mld. euro. De lijst wordt aangevoerd door Nestlé (21,4 mld. euro), Lactalis (17,7 mld. euro) en Danone (15,5 mld. euro).

\section{Consumptie}

Supermarkten kopen melk en zuivelproducten van de zuivelindustrie. In Nederland wordt driekwart van de zuivelproducten via de retail verkocht en een kwart via de horeca en andere kanalen. Het totaal aan bestedingen aan zuivel in alle verkoopkanalen voor voedsel in Nederland wordt geraamd op circa $5,8 \mathrm{mld}$. euro in 2018 . Binnen de retail wordt $91 \%$ van de zuivelproducten via supermarkten aan consumenten verkocht.

De Nederlandse kaasconsumptie per hoofd van de bevolking beweegt zich al jaren boven het Europese gemiddelde, maar is iets aan het dalen. In 2016 bedroeg de kaasconsumptie in Nederland 23,2 kg, tegen $18,5 \mathrm{~kg}$ per hoofd van de bevolking in de EU-28; in 2018 ging het om respectievelijk 21,7 kg en 18,7 kg. De consumptie van room en consumptiemelk per hoofd van de bevolking daalde ook tussen 2016 en 2018: van respectievelijk $1,4 \mathrm{~kg}$ en $49,4 \mathrm{~kg}$ naar $1,0 \mathrm{~kg}$ en $42,0 \mathrm{~kg}$.

\section{Duurzame Zuivelketen}

De zuivelindustrie en melkveehouders willen dat de Nederlandse zuivelsector wereldwijd koploper is in duurzaamheid. Met steun van de overheid is hiertoe het Publiek Private Samenwerkingsinitiatief Duurzame Zuivelketen ontwikkeld. Gezamenlijk streven zuivelondernemingen (NZO) en melkveehouders (LTO) naar een toekomstbestendige en verantwoorde sector. Het gaat om uiteenlopende aspecten zoals: veilig en met plezier werken, een goed inkomen verdienen, kwalitatief hoogwaardige voeding produceren, met respect omgaan met dieren en milieu en door de Nederlandse samenleving gewaardeerd worden. Voor 2020 zijn de volgende doelen geformuleerd: klimaatneutrale ontwikkeling, continue verbetering van dierenwelzijn, behoud 
van weidegang en behoud van biodiversiteit en milieu. De deelnemende zuivelondernemingen hebben een eigen duurzaamheidsprogramma om deze doelen te realiseren. In de programma's wordt onder andere nieuwe kennis beschikbaar gesteld, kunnen duurzaamheidsprestaties van melkveehouders onderling worden vergeleken, krijgen melkveehouders een financiële stimulans bij het realiseren van bepaalde prestaties en worden - indien nodig - niet-vrijblijvende maatregelen getroffen. In 2019 heeft de Duurzame zuivelketen doelen en ambities vastgesteld voor 2030. Als onderdeel van het initiatief stelt Wageningen Economic Research jaarlijks een sectorrapportage op waarin de voortgang bij de realisatie van de doelen in kaart wordt gebracht. ${ }^{16}$

\subsubsection{Kalveren}

\section{Algemene beschrijving}

De Nederlandse kalversector was in 2020 met een aandeel van 33\% van het aantal geslachte dieren en 36\% van het totale volume, de grootste producent van kalfsvlees in Europa, gevolgd door Frankrijk (26\%). Met Italië, Denemarken en België erbij zijn deze vier landen goed voor $88 \%$ van de totale kalfsvleesproductie in Europa (EC, 2021).

In 2021 zijn er circa 996.000 plaatsen voor vleeskalveren op 1.620 bedrijven in Nederland (figuur 2.13) (CBS, 2021a). In totaal werden er in 2020 1.694.916 kalveren (blank en rose) opgezet (SKV). Kalveren die in de melkveehouderij worden geboren en niet worden aangehouden als nieuwe aanwas, worden ingezet als vleeskalf (vrijwel alle mannelijke dieren en een deel van de vrouwelijke dieren). Deze kalveren blijven ten minste 14 dagen (meestal in individuele hokken) op het geboortebedrijf en worden vervolgens met leeftijdgenoten op gespecialiseerde vleeskalverbedrijven geplaatst. In de Nederlandse kalversector worden zowel blankvleeskalveren als rosékalveren gehouden. Blankvleeskalveren (met een gemiddelde leeftijd bij het slachten van 25 weken) hebben een levend eindgewicht van $225 \mathrm{~kg}$; jonge rosékalveren (een gemiddelde leeftijd bij het slachten van 30 weken) een levend eindgewicht van $300 \mathrm{~kg}$, oude rosékalveren (een gemiddelde leeftijd bij het slachten van 40 weken) een levend eindgewicht van $360 \mathrm{~kg}$.

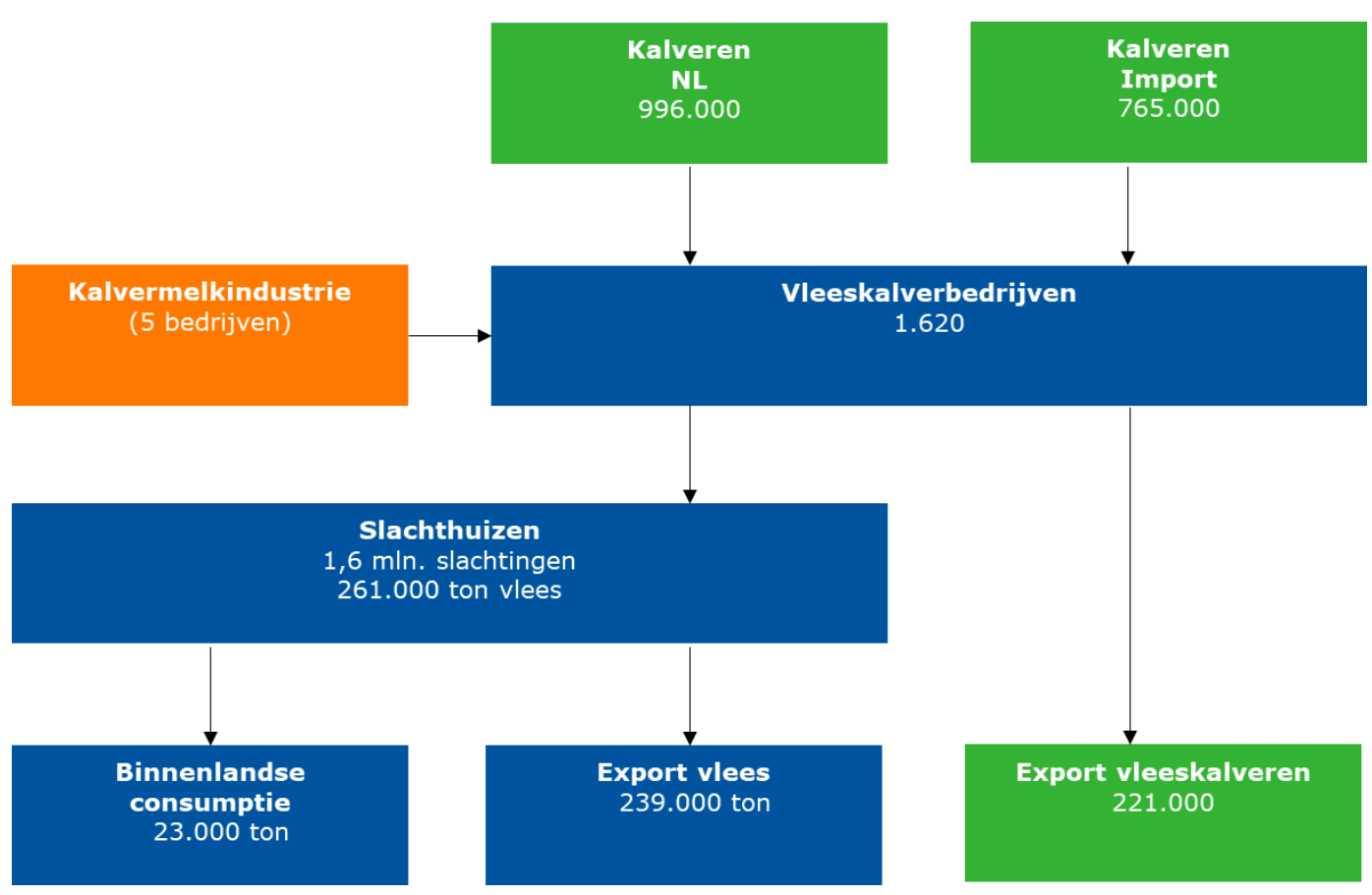

Figuur 2.13 Globaal overzicht van de keten rond de vleeskalverhouderij, 2020 Bron: Agrimatie.nl, Wageningen Economic Research.

\footnotetext{
16 https://research.wur.nl/en/publications/sectorrapportage-duurzame-zuivelketen-prestaties-2018-in-perspect
} 
Op deze bedrijven worden per jaar tussen de 1,6 en 1,7 mln. kalveren per jaar opgezet. De kalveren op de vleeskalverbedrijven zijn niet alleen afkomstig van Nederlandse melkveebedrijven, een substantieel deel van de kalveren wordt geïmporteerd. Ongeveer de helft van de kalveren die op de Nederlandse vleeskalverbedrijven worden ingezet is afkomstig uit het buitenland. Van de 765.000 vleeskalveren die in 2020 werden geïmporteerd, was $77 \%$ afkomstig uit Duitsland, $6 \%$ uit Ierland en $5 \%$ uit Denemarken. In 2020 zijn er 96.623 minder kalveren geïmporteerd dan in 2019. De reden is de verstoorde afzet van kalfsvlees door de coronacrisis (Rvo, 2021a). In vergelijking met 2010 is het percentage kalveren vanuit Oost-Europa (inclusief Letland, Estland en Litouwen) sterk afgenomen van 36\% in 2010 naar $6 \%$ in 2020 (RVO, 2021). Werden in 2018 in Nederland nog 6 mln. kalveren geslacht, in 2020 was dit afgenomen tot 1,6 mln. kalveren (EC, 2021). Het grootste deel van de (blank) kalfsvleesproductie wordt geëxporteerd. Deze export vindt vooral plaats naar Frankrijk en Italië, waarbij export naar nieuwe derde landen op gang komt.

\section{Waardeketens/Integraties}

Het Nederlandse vleeskalvercomplex wordt gekenmerkt door een sterk integratiemodel binnen de keten. Daarmee zijn veel facetten van de totale productieketen aan elkaar gekoppeld. Onderdelen van deze keten zijn: het verzamelen en sorteren van nuchtere kalveren (in binnen- en buitenland), het opzetten bij kalvermesters, de technische en veterinaire begeleiding, de productie van de voeders, het transport zowel van nuchtere kalveren als ook van slachtrijpe dieren, het slachten, het verwerken van de huiden en de vleesversnijding tot consumentenverpakking. Het grootste deel van de kalveren in Nederland wordt geproduceerd door drie integraties: de VanDrie Groep, Denkavit en de Pali Groep. ${ }^{17}$ Deze grotere bedrijven beheren meerdere schakels van de uitgebreide productieketen. De integratie is dan contractgever, eigenaar van het kalf en levert ook het voer. De kalverhouder levert de huisvesting en de arbeid. De contractprijzen waren in 2020 gemiddeld 215 euro per kalverplaats. De kalverhouders met contract hebben over de jaren een redelijk stabiel inkomen van gemiddeld circa 40.000 euro per onbetaalde arbeidsjaareenheid. Rosékalveren worden meestal voor eigen risico van de boer gehouden. ${ }^{18}$

De VanDrie Groep heeft zich ontwikkeld tot een internationale geïntegreerde keten van bedrijven. De bedrijven die binnen de keten actief zijn, zijn als volgt in te delen: kalverhouderijen (in Nederland en Frankrijk), Kalvervoeders (Nederland, Frankrijk, Italië en Duitsland), zuivelgrondstoffen (Nederland, Frankrijk en Italië), kalverslachterijen (Nederland en Frankrijk), runderslachterijen (Nederland), kalfsvellen en een voorlichtingsorganisatie voor de promotie van kalfsvlees. Denkavit is een belangrijke speler waarbij internationaal de nadruk is op de productie en verkoop van voeding voor jonge dieren (Nederland, Frankrijk, Duitsland, Italië en Spanje) en heeft daarnaast in Nederland ook kalverhouderijen onder contract. De Paligroep is actief in de schakels: het kalverhouderijbedrijf, het slachten en uitbenen en de verkoop. Deze activiteiten spelen zich vooral af in Nederland.

\section{Sterkten en zwakten van het de kalverketen}

Het vleeskalvercomplex wordt beoordeeld als een cluster dat betekenisvol is voor de Nederlandse economie (toegevoegde waarde, werkgelegenheid, betalingsbalans), competitief maar beperkt innovatief is, waarbij de legitimiteit in de samenleving sterk onder druk staat (dierenwelzijn) en een sterke exportafhankelijkheid (90-95\% van het geproduceerde kalfsvlees wordt geëxporteerd).

Rond dierenwelzijn spelen verschillende onderwerpen. Vanuit andere lidstaten wordt een groot aantal kalveren naar Nederland gehaald wordt om hier te worden afgemest. Ongeveer de helft van de kalveren in de Nederlandse vleeskalverhouderij komt uit het buitenland. Wel worden de laatste jaren steeds meer kalveren vanuit omliggende lidstaten gehaald en daalt het aantal kalveren die over een langere afstand vervoerd zijn. Transportduur van kalveren die niet uit direct omliggende landen komen kan oplopen tot meer dan 24 uur. Mede door vaak gebrekkige voorzieningen om dieren te voeden kan dit gepaard gaan met verminderd dierenwelzijn (Marcato, 2021). Er is dan ook veel druk vanuit politiek en samenleving om het lange afstand transport van jonge kalveren aan banden te leggen.

\section{Diergezondheid}

Uitdagingen op het gebied van diergezondheid en dan met name longaandoeningen resulteren in een relatief hoog antibioticagebruik in de vleeskalverhouderij. Het grote aantal herkomstbedrijven speelt hier bij een rol.

\footnotetext{
17 Daarnaast zijn er nog een aantal kleinere integraties of veehandelaren die contracten met vleeskalverhouders hebben.

${ }^{18}$ Voor rosékalverbedrijven zijn geen gegevens beschikbaar in het Bedrijveninformatienet.
} 
Maar ook de leeftijd van de dieren tijdens transport, omstandigheden van de dieren tijdens het herkomstbedrijf, transport en mengen van verschillende herkomsten en soms een laag geboortegewicht hebben allemaal hun effect op het antibioticagebruik. Pogingen om alleen kalveren met een gewicht boven de $30 \mathrm{~kg}$ in de vleeskalverhouderij op te zetten stuitten op veel weerstand in de melkveehouderij en zijn teruggedraaid. Ondanks dat het antibioticagebruik sinds 2009 met $51 \%$ is afgenomen (tegen $69 \%$ in de andere sectoren) is er nog steeds een groot aantal bedrijven met een hoog antibioticagebruik. Een sectorbrede aanpak blijft noodzakelijk om het aantal bedrijven in het actiegebied te verlagen (AD, 2021).

\section{Stikstof}

Net als bij de andere veehouderijsectoren zullen ook maatregelen die getroffen gaan worden om de stikstofcrisis te beheersen niet aan de kalversector voorbijgaan. De sterke concentratie van de bedrijven in de Gelderse Vallei in de nabijheid van Natura 2000-gebieden beperkt ontwikkelingsmogelijkheden van bestaande bedrijven. $\mathrm{Er}$ is dan ook veel belangstelling bij vleeskalverbedrijven om aan opkoopregelingen deel te nemen. Zo heeft de Provincie Gelderland $20 \mathrm{mln}$. euro beschikbaar gesteld voor een opkoopregeling en is er 10,5 mln. euro beschikbaar aan subsidie voor kalverhouders die willen overstappen naar een duurzaam en vernieuwend stalsysteem als onderdeel van de Gelderse Maatregelen Stikstof (GMS). Ook wil het ministerie van LNV Maatregel Gerichte opkoop van veehouderijbedrijven bij stikstofgevoelige Natura 2000-gebieden uitbreiden naar sectoren met vleeskalveren en geiten.

\subsubsection{Sierteelt}

In Nederland waren er in 2020 nog ongeveer 110 opkweekbedrijven voor uitgangsmateriaal voor snijbloemen onder glas. Daarnaast zijn er bedrijven die zich bezig houden met het opkweken van gewassen uit zaad. Het aantal bedrijven lijkt de laatste jaren te stabiliseren. Gemeten in ha zijn het relatief kleine bedrijven.

Ondanks de soms wat kleine omvang in hectares zijn deze bedrijven wel internationaal actief. Een deel van het uitgangsmateriaal voor de snijbloementeelt in Nederland wordt namelijk ook in het buitenland gemaakt. Een voorbeeld hiervan zijn chrysantenstekken. In Tanzania heeft het Nederlandse chrysantenveredelingsbedrijf Dekker een eigen vestiging waar ook chrysantenstekken worden geproduceerd. Deze worden geplukt en vervolgens verkocht aan klanten in onder andere Nederland. Veelal hebben verdelingsbedrijven verschillende vestigingen om nieuwe rassen speciaal voor bepaalde gebieden uit te testen en liggen deze bedrijven dicht bij belangrijke teeltgebieden, waarvan Nederland er één is.

\section{Stabilisatie van teeltbedrijven en areaal}

In Nederland zijn er 1.006 bedrijven die snijbloemen produceren, 589 bedrijven die kamerplanten telen en 247 bedrijven die tuinplanten opkweken (CBS landbouwtelling, 2021). Het areaal snijbloemen in Nederland schommelt sinds 2015 rond de 1.700 tot 1.900 ha. Het lijkt er op dat de daling die voor 2015 werd ingezet stabiliseert op 1.800 ha. Ook het aantal bedrijven lijkt niet verder te dalen (zie ook paragraaf 4.2.1). In eerdere jaren daalde het aantal bedrijven sterk. De economische situatie van het bedrijf, overname, geen opvolger, geen uitbreidingsmogelijkheden of opkoop vanwege woningbouw droegen daar onder andere aan bij. Belangrijke gewassen zijn chrysanten, rozen, gerbera, lelie en tulpen. Veel rozentelers zijn noodgedwongen gestopt vanwege internationale concurrentie. Veel rozen komen tegenwoordig uit Kenia, Ethiopië en Uganda waar arbeid relatief goedkoper is en de klimatologische omstandigheden gunstig zijn.

Bij potplanten lijkt de groei van bloeiende kamerplanten af te vlakken. In eerder jaren groeide het areaal bloeiende planten juist sterk door onder andere de populariteit van de Phalaenopsis (een orchidee). De groei van het areaal groenblijvende planten stijgt juist weer, na jaren van daling. Per saldo blijft het areaal al jaren rond de 1.400 ha schommelen. Er is een grote diversiteit aan producten die worden geteeld. Ook de bedrijfsinrichting verschilt sterk. Qua omvang zijn glasgroentebedrijven vaak groter dan bedrijven in de sierteelt. Sierteeltproductiebedrijven werken vaak samen of hebben soms meerdere vestigingen om grote orders in te vullen. Samenwerking is er op het gebied van afzet, teelt en assortimentskeuze.

\section{Nederland draaischijf in bloemen en plantenhandel}

Bloemen, planten, bomen, bollen en uitgangsmateriaal zijn de belangrijkste exportproducten binnen de landbouwsector. In 2020 bedraagt de exportwaarde voor de totale sierteeltsector 9,5 mld. euro (Jukema 
et al., 2021). De export van snijbloemen bedroeg in 2020 ongeveer 4 mld. euro. De kamer- en tuinplanten export bedraagt 2,7 mld. euro (zie figuur 2.14). Delen van deze export wordt eerst geïmporteerd en verwerkt op onder andere de bloemenveilingen. Snijbloemen worden vooral naar buurlanden zoals Duitsland, het VK en Frankrijk geëxporteerd, maar gaan in kleinere hoeveelheden naar alle uithoeken van de wereld.

In Nederland bedraagt de importwaarde van snijbloemen 1,2 mld. euro, van kamer- en tuinplanten 0,4 mld. euro (zie figuur 2.14). Veel import komt uit landen zoals Kenia, Ethiopië, Ecuador en Colombia. Naast rechtstreekse import worden deze bloemen ook naar Belgische en Duitse vluchthavens gevlogen om vervolgens toch bij de Nederlandse veiling terecht te komen voor verkoop en verdere verwerking. Dergelijke routes worden gekozen vanwege de beschikbaarheid van vrachtcapaciteit bij passagiersvluchten of vanwege kostenoverwegingen. Samen met de beschikbare producten van Nederlandse bodem vormen de importproducten een alles omvattend assortiment voor de handelsbedrijven, die in Nederland veelal in de buurt van de bloemenveilingen zijn gevestigd.

\section{Veiling zet in op digitalisering, landelijk veilen en duurzaamheid}

De bloemenveiling zet sterk in op digitalisering van het logistieke proces. Bloemen en planten kwamen voorheen allemaal fysiek voor de klok of werden verkocht via bemiddeling. In de nabije toekomst wil men over op een volledige digitaal aanbod via Floriday. Daarnaast wil men over op een systeem van landelijk veilen via een digitale klok, zo kan al het aanbod in heel Nederland tegelijkertijd geveild worden. Deze veranderingen en de snelheid waarmee de veiling dit wil realiseren stuit op bezwaren van kwekers en handelaren. Systemen zijn hier nog niet klaar voor, is onder andere de kritiek. Maar ook geven kleine handelshuizen aan niet de mankracht te hebben om op 20 klokken tegelijk in te kopen. Kwekers geven aan fysieke controle in hun ogen noodzakelijk blijft voor een juiste prijsvorming, omdat foto's niet altijd voldoende informatie geven.

Duurzaamheid speelt een steeds belangrijker rol in de sierteeltsector. Volgens ABN AMRO (2021), vindt bijna $70 \%$ van de consumenten in Nederland het belangrijk dat bloemen en planten duurzaam zijn geteeld. De bloemenveiling Royal FloraHolland (RFH) kan daarin als belangrijke speler in de keten dan ook niet achterblijven. RFH heeft het doel dat alle aanvoerders in de toekomst een digitale certificering hebben, te tonen bij de verhandeling van producten via de veiling. RFH geeft aan dat zijn 455 kwekers eind 2020 begonnen zijn met een digitale milieuregistratie.

\section{Minder groothandelaren en detailhandel}

Het aantal groothandelaren in bloemen en planten in Nederland bedroeg zo'n 2.495 eind 2019, tegen 2.800 eind 2017. Van deze bedrijven is bijna de helft (1.200 stuks) een eenmanszaak. Nog eens 800 bedrijven zijn niet groter dan 5 werkzame personen. Een kleine 400 bedrijven hebben een personele omvang van maximaal 20 personen. Bij 85 bedrijven werken tussen de 20 en 50 personen en er zijn eind 201930 bedrijven met meer dan 50 man personeel. In alle categorieën daalde het aantal bedrijven in deze periode, uitgezonderd de allergrootste. Daar steeg het aantal bedrijven van 20 naar 25 tussen 2017 en eind 2019.

Groothandelsbedrijven zijn er in soorten en maten. Zogenaamde lijnrijders rijden via een bepaalde route langs bloemenwinkels om hun bloemen en planten te verkopen. Er zijn grote handelsbedrijven die de retail beleveren via hun distributiecentra. Andere leveren aan Cash and Carries waar bloemisten kunnen inkopen. Een van de grotere bedrijven is de Dutch Flower Group (DFG). DFG is de grootste bloemenhandelaar ter wereld met een omzet van 1,7 mld. euro en bestaat uit een groot aantal min of meer zelfstandige handelaren met elk hun eigen specialisme of afzetgebied. Het bedrijf neemt regelmatig handelsbedrijven over. In 2020 gebeurde dit met Dames Plants en Superplant (Hortipoint.nl, 2020). Ook gingen Waterdrinker, OZ Planten en Hamiplant (onderdeel van DFG) samen. Dutch Flower Group nam ook Panalpina Airflo over. Hiermee verstevigde DFG haar positie in de supply chain (koelketen) vanuit Afrika (Floranews, 2021). Een verdere integratie van handelsbedrijven lijkt waarschijnlijk omdat ook de retail uit steeds grotere inkooporganisaties bestaat. Ook handelsbedrijven zijn daarom steeds vaker gericht op een speciale doelgroep. Dit kan het retailkanaal zijn of juist de bloemist. Naast de productlevering ontzorgen handelsbedrijven hun afnemers door eigen webwinkels op te zetten en category management aan te bieden.

Het aantal bloemisten daalt ook. In 2017 waren er nog 3.600 stuks, eind 2019 was dit gezakt naar 3.135. Toch is in Nederland de bloemist nog altijd het belangrijkste afzetkanaal, gevolgd door supermarkten en de 
ambulante handel. Dit aandeel daalt niet echt. Bloemisten kunnen zich nog altijd voldoende onderscheiden van supermarkten. Denk hierbij aan trouw- en rouwwerk. Voor de kamerplanten staan de tuincentra op de eerste positie met een derde van de totale markt. Bloemisten en supermarkten hebben beide een aandeel van ongeveer $20 \%$. Bij planten is de onlineverkoop al best goed ontwikkeld met een geschat aandeel van $12 \%$. Er is nog veel potentieel voor supermarkten om grotere aantallen te gaan verkopen, maar dan moeten supermarkten wel professioneler gaan handelen (Floranews, 2021a).

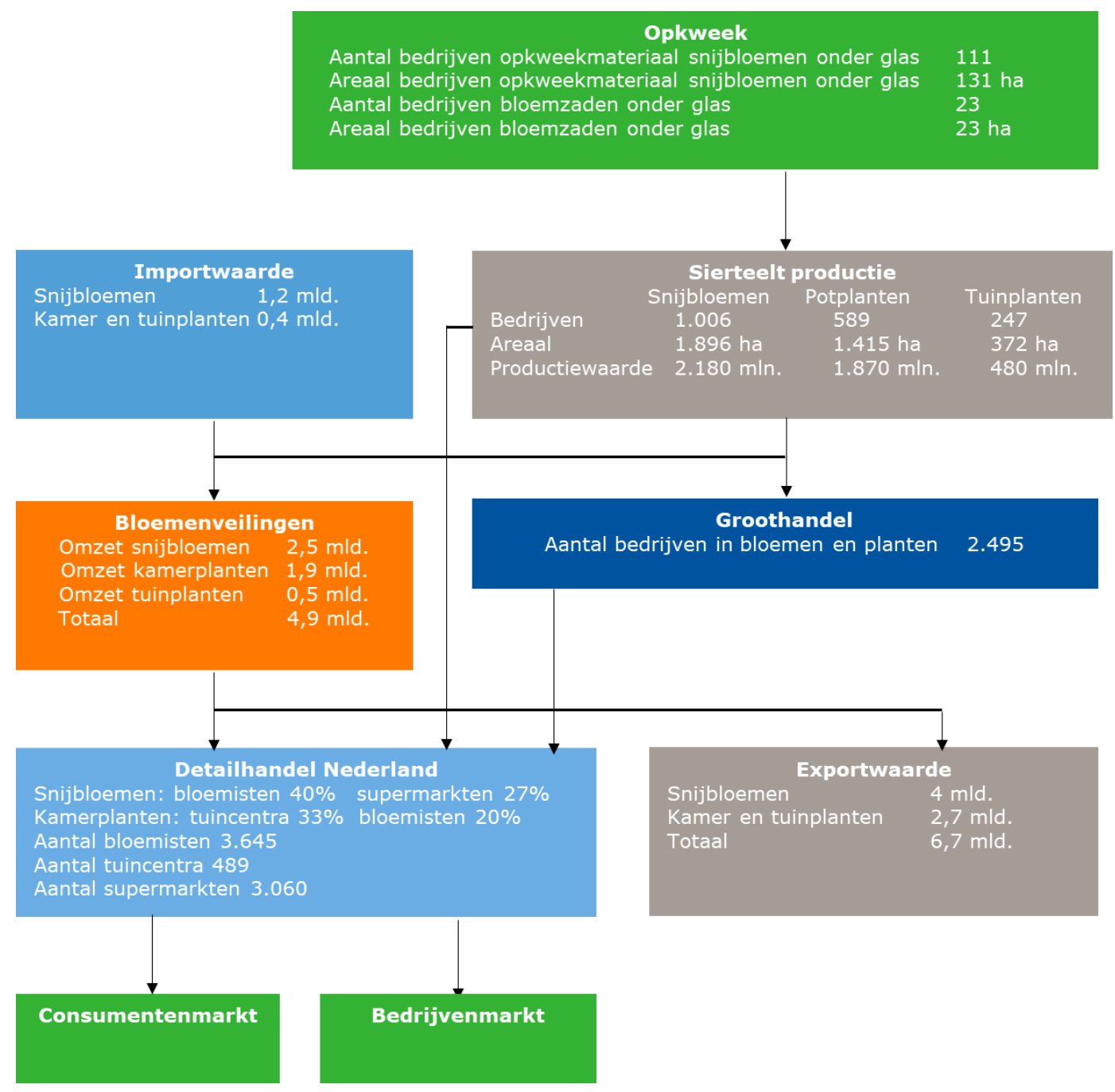

Figuur 2.14 Globaal overzicht van de sierteeltketen, 2020

Bron: CBS, Wageningen Economic Research, Floranews.

\section{$2.4 \quad$ Buitenlandse handel ${ }^{19}$}

Nederland is ook in 2020, in waarde gemeten, het tweede exportland, inclusief wederuitvoer, van landbouwgoederen in de wereld na de Verenigde Staten van Amerika (VS) (figuur 2.15). Ook bij de import staat Nederland in de top 5 (figuur 2.16). Maar hoe heeft deze handel zich over een wat langere periode ontwikkeld? Welke landen spelen een rol bij deze import en exportstromen en veranderen de hoofdrolspelers gedurende een langere periode ook? Welke goederen worden er verhandeld en verandert het productenpakket? Deze korte beschouwing gaat hierop in voor de periode 2000-2020.

\footnotetext{
${ }^{19}$ Omwille van de vergelijking met andere landen is de basis voor deze paragraaf de COMTRADE-database. De handelscijfers op basis van deze database zijn in dollars. Onder meer vanwege definitiekwesties kunnen de handelscijfers afwijken van de cijfers over de Nederlandse in- en uitvoer die jaarlijks worden gepubliceerd in de gezamenlijke publicatie van Wageningen Economic Research en CBS over de internationale handelspositie van Nederland (voor 2021: https://edepot.wur.nl/539722). De database voor laatstgenoemde publicatie geeft enkel informatie over de in- en uitvoer van Nederland.
} 
De mondiale top 5 in beeld

De VS zijn de grootste exporteur van landbouwgoederen. In alle landen die in 2020 de top vijf exportlanden vormen steeg de export in 20 jaar tijd sterk. De export van Duitsland stijgt na 2010 maar beperkt en datzelfde is het geval voor de VS en China na 2015.

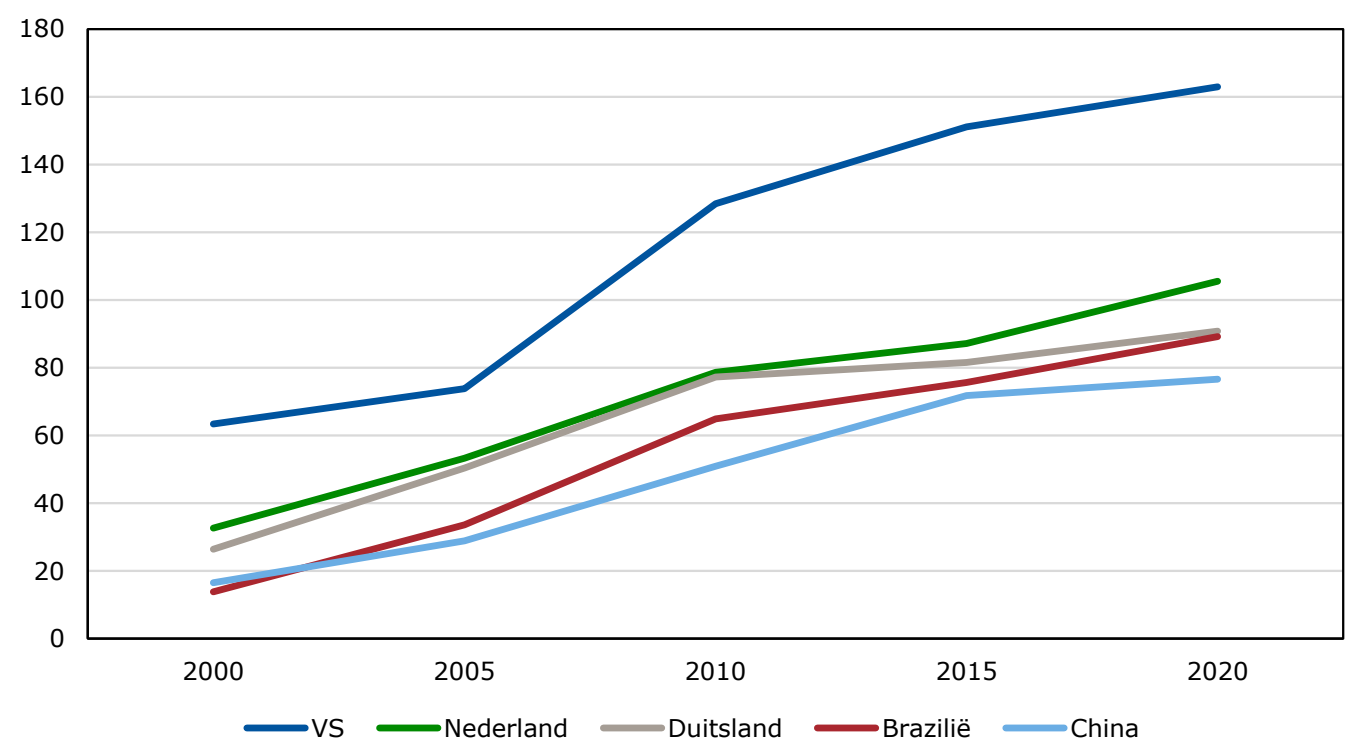

Figuur 2.15 Exportwaarde grootste exporteurs (in m/d. dollar)

Bron: Comtrade, bewerking Wageningen Economic Research.

Nederland is in waarde gemeten nummer vijf bij de import van landbouwgoederen in de wereld, maar desondanks een kleine speler vergeleken bij de twee grootste importeurs China en de VS. China importeerde in 2020 meer landbouwgoederen dan de VS. Die verandering werd al ingezet rond 2005 toen de gemiddelde groei per jaar sterker toename dan die van de VS. De groei van de importwaarde ligt bij Japan en Duitsland op een lager niveau. Nederland heeft een stabiele groei en lijkt Japan de komende jaren in te gaan halen.

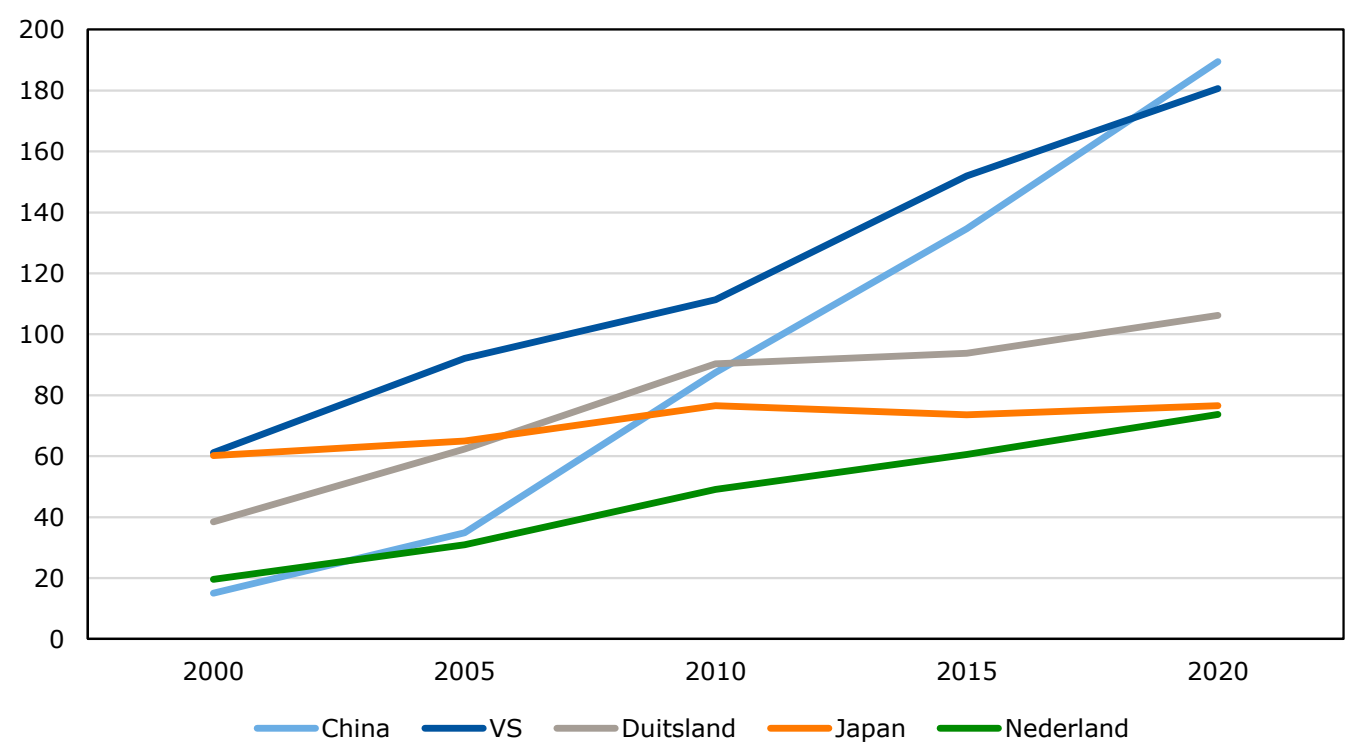

Figuur 2.16 Importwaarde grootste importeurs (in mld. dollar) Bron: Comtrade, bewerking Wageningen Economic Research. 


\section{Geografische bestemming handel Nederland}

De export van land- en tuinbouwgoederen vanuit Nederland bedroeg in 2020 105,6 mld. dollar. Dit bedrag is nog uitgezonderd land- en tuinbouw gerelateerde handel zoals tractoren en kasmaterialen. Twintig jaar geleden was dit nog ongeveer één derde (tabel 2.1). Hoewel de waarde sterk is gestegen in deze periode, is er in de bestemming nauwelijks iets veranderd. Verdeeld naar werelddeel gaat er in 2020 ruim $81 \%$ naar Europa, ruim 10\% naar Azië, 5\% naar Amerika en 3\% naar Afrika. Ongeveer 1\% gaat naar Oceanië. In de afgelopen 20 jaar is het aandeel richting Azië gegroeid van 7\% naar 10\%, onder andere door de sterke groei van de export van babymelkpoeder naar China, terwijl het aandeel naar Europa en Amerika met respectievelijk $3 \%$ en $2 \%$ daalde.

Tabel 2.1 Export van landbouwgoederen van Nederland naar werelddeel, in mln. dollar en aandeel

\begin{tabular}{lrrrrrrrrrr}
\hline & $\mathbf{2 0 0 0}$ & \% & $\mathbf{2 0 0 5}$ & \% & $\mathbf{2 0 1 0}$ & \% & $\mathbf{2 0 1 5}$ & \% & $\mathbf{2 0 2 0}$ & \% \\
\hline Afrika & 908 & 3 & 1.372 & 3 & 2.514 & 3 & 2.768 & 3 & 3.000 & 3 \\
\hline Amerika & 2.191 & 7 & 3.100 & 6 & 3.562 & 5 & 4.033 & 5 & 5.208 & 5 \\
\hline Azië & 2.169 & 7 & 3.076 & 6 & 5.815 & 7 & 8.188 & 9 & 10.995 & 10 \\
\hline Europa & 27.275 & 84 & 45.530 & 85 & 66.541 & 85 & 71.628 & 82 & 85.501 & 81 \\
\hline Oceanië & 101 & 0 & 221 & 0 & 273 & 0 & 561 & 1 \\
\hline Totaal & 32.644 & & 53.299 & & 78.705 & & 85.177 & & 105.560 &
\end{tabular}

Bron: Comtrade, bewerking Wageningen Economic Research.

De 10 belangrijkste exportbestemmingen van Nederland veranderen over de tijd ook maar zeer beperkt (tabel 2.2). In de top 5 is alleen China een nieuwkomer en heeft daarmee hierdoor Italië naar de zesde plaats verdrongen. Het aandeel van China in het exporttotaal bedraagt $4 \%$ in 2020 . Verder is Polen belangrijker geworden als exportland voor Nederland, het aandeel steeg van $2 \%$ naar $3 \%$. Het aandeel van de top 10 landen neemt op het totaal wel af. In 2000 was dit nog 77\%, in 2020 is dit gezakt naar $72 \%$. Veruit het grootste deel van de Nederlandse export gaat naar omringende landen. In 2000 was Duitsland, België, Frankrijk en het Verenigd Koninkrijk goed voor 57\% van de export. In 2020 is dit wel iets lager (54\%) maar nog altijd meer dan de helft van alle landbouwgoederen.

Tabel 2.2 Top 10 bestemmingen Nederlandse landbouwexport naar aandeel

\begin{tabular}{|c|c|c|c|c|c|c|}
\hline & 2000 & $\begin{array}{l}\text { \% t.o.v. } 2005 \\
\text { totaal }\end{array}$ & $\begin{array}{l}\% \text { t.o.v. } 2010 \\
\text { totaal }\end{array}$ & $\begin{array}{l}\% \text { t.o.v. } 2015 \\
\text { totaal }\end{array}$ & $\begin{array}{l}\% \text { t.o.v. } 2020 \\
\text { totaal }\end{array}$ & $\begin{array}{r}\% \text { t.o.v. } \\
\text { totaal }\end{array}$ \\
\hline 1 & Duitsland & 26 Duitsland & 25 Duitsland & 26 Duitsland & 26 Duitsland & 26 \\
\hline 2 & Frankrijk & $12 \mathrm{VK}$ & 11 Frankrijk & 10 België & 11 België & 11 \\
\hline 3 & VK & 11 Frankrijk & $10 \mathrm{VK}$ & $10 \mathrm{VK}$ & $10 \mathrm{VK}$ & 9 \\
\hline 4 & België & 8 België & 9 België & 10 Frankrijk & 8 Frankrijk & 8 \\
\hline 5 & Italië & 8 Italië & 7 Italië & 5 Italië & 4 China & 4 \\
\hline 6 & VS & $5 \mathrm{VS}$ & 4 Spanje & $3 \mathrm{VS}$ & 3 Italië & 3 \\
\hline 7 & Spanje & 3 Spanje & $4 \mathrm{VS}$ & 3 Spanje & 3 Polen & 3 \\
\hline 8 & Griekenland & 2 Zweden & 2 Rusland & 2 Zweden & 2 Spanje & 3 \\
\hline 9 & Zweden & 2 Rusland & 2 Zweden & 2 Polen & $2 \mathrm{VS}$ & 3 \\
\hline 10 & Denemarken & 1 Denemarken & 2 Polen & 2 China & 2 Zweden & 2 \\
\hline Totaal & & 77 & 77 & 73 & 72 & 72 \\
\hline
\end{tabular}

Bron: Comtrade, bewerking Wageningen Economic Research.

Ook de importstromen van Nederland zijn in 20 jaar tijd vrij stabiel (tabel 2.3). Evenals bij de export is de absolute waarde sterk gestegen, maar zijn de veranderingen qua werelddeel beperkt. Uit Europa komt $63 \%$ van de totale waarde aan landbouwgoederen in 2020, uit Amerika 17\% van de import, uit Azië $10 \%$ en Afrika $8 \%$. Oceanië heeft een bescheiden aandeel van $2 \%$ in de import van Nederland. 
Tabel 2.3 Nederlandse landbouwimport naar werelddeel, in $\mathrm{mln}$. dollar en aandeel

\begin{tabular}{|c|c|c|c|c|c|c|c|c|c|c|}
\hline & 2000 & $\%$ & 2005 & $\%$ & 2010 & $\%$ & 2015 & $\%$ & 2020 & $\%$ \\
\hline Afrika & 1.444 & 7 & 2.613 & 8 & 4.529 & 9 & 4.964 & 8 & 6.093 & 8 \\
\hline Amerika & 4.221 & 22 & 5.802 & 19 & 9.599 & 20 & 10.615 & 18 & 12.412 & 17 \\
\hline Azië & 2.040 & 10 & 3.121 & 10 & 5.683 & 12 & 6.101 & 10 & 7.226 & 10 \\
\hline Europa & 11.669 & 60 & 18.967 & 61 & 28.751 & 58 & 38.060 & 63 & 46.755 & 63 \\
\hline Oceanië & 230 & 1 & 432 & 1 & 597 & 1 & 792 & 1 & 1.223 & 2 \\
\hline Totaal & 19.604 & & 30.934 & & 49.159 & & 60.532 & & 73.709 & \\
\hline
\end{tabular}

Bron: Comtrade, bewerking Wageningen Economic Research.

Verreweg de belangrijkste importlanden zijn onze buurlanden België, Frankrijk en Duitsland (tabel 2.4). In de afgelopen 20 jaar schommelt het aandeel van deze top drie rond de $40 \%$. Naast de buurlanden zijn de VS en Brazilië belangrijke herkomstlanden. In de top 10 importlanden van Nederland zijn meer landen uit andere werelddelen vertegenwoordigd dan bij de export, zeker aan het begin van deze eeuw. In de top hebben drie Europese landen de plek ingenomen van Argentinië, Maleisië en Indonesië. Het belang van de top 10 landen neemt over de jaren heen wel af, de import komt uit steeds meer landen.

Tabel 2.4 Top 10 herkomstlanden Nederlandse landbouwimport naar aandeel

\begin{tabular}{|c|c|c|c|c|c|c|}
\hline & 2000 & $\begin{array}{l}\text { \% t.o.v. } 2005 \\
\text { totaal }\end{array}$ & $\begin{array}{l}\text { \% t.o.v. } 2010 \\
\text { totaal }\end{array}$ & $\begin{array}{l}\text { \% t.o.v. } 2015 \\
\text { totaal }\end{array}$ & $\begin{array}{l}\text { \% t.o.v. } 2020 \\
\text { totaal }\end{array}$ & $\begin{array}{r}\% \text { t.o.v. } \\
\text { totaal }\end{array}$ \\
\hline 1 & Duitsland & 17 Duitsland & 21 Duitsland & 18 Duitsland & 19 Duitsland & 17 \\
\hline 2 & België & 13 België & 13 België & 12 België & 13 België & 13 \\
\hline 3 & Frankrijk & 9 Frankrijk & 8 Frankrijk & 9 Frankrijk & 7 Frankrijk & 6 \\
\hline 4 & VS & 8 Brazilië & 8 Brazilië & 7 Brazilië & 6 Brazilië & 4 \\
\hline 5 & Brazilië & 7 Spanje & $4 \mathrm{VS}$ & $4 \mathrm{VS}$ & $4 \mathrm{VS}$ & 4 \\
\hline 6 & VK & $4 \mathrm{VS}$ & $4 \mathrm{VK}$ & $3 \mathrm{VK}$ & 4 Spanje & 4 \\
\hline 7 & Spanje & $4 \mathrm{VK}$ & 3 Spanje & 3 Spanje & $3 \mathrm{VK}$ & 4 \\
\hline 8 & Indonesië & 2 Argentinië & 3 Argentinië & 3 Polen & 3 Polen & 3 \\
\hline 9 & Argentinië & 2 Maleisië & 2 Indonesië & 3 Italië & 3 Italië & 3 \\
\hline \multirow[t]{2}{*}{10} & Maleisië & 2 Indonesië & 2 Maleisië & 3 Indonesië & 2 Oekraïne & 2 \\
\hline & Totaal & 68 & 68 & 64 & 63 & 61 \\
\hline
\end{tabular}

Bron: Comtrade, bewerking Wageningen Economic Research.

\section{Handel naar productgroep}

Op productgroepsniveau komen grotendeels dezelfde producten terug in de export top 10 over de onderzochte periode (tabel 2.5). Snijbloemen, kamerplanten en kaas bevinden zich veelal in de top 3. Dit zijn producten met een relatieve hoge toegevoegde waarde. Sigaretten, in 2000 nog het belangrijkste product, is na 2010 uit de top 10 weggevallen. In alle jaren komt vlees in de top 10 voor, met rundvlees, varkensvlees en kippenvlees. Ook diervoeders staan al 20 jaar in deze top. Babymelkpoeder en zaden zijn producten die in recentere jaren tot belangrijke exportproducten van Nederland worden gerekend.

De belangrijkste producten die Nederland importeert in waarde gemeten zijn voor een deel grondstoffen. Een voorbeeld hiervan zijn de cacaobonen die gebruikt worden voor het maken van chocoladeproducten. In de afgelopen 20 jaar is het belang hiervan gegroeid (tabel 2.6). Daarnaast zijn sojabonen en palmolie veel geïmporteerde producten die als grondstof worden ingezet voor diverse consumptieartikelen. Andere producten die in de top 10 staan produceert Nederland niet of nauwelijks zelf. Wijn, vruchtensappen, citrusvruchten of andere exotische vruchten zoals avocado's zijn daar voorbeelden van. Maar er staan ook producten tussen die Nederland zelf produceert. Zo staat kaas diverse keren in top 10 van meest belangrijke producten en ook snijbloemen, rundvlees en melk(producten) komen af en toe voor. 
Tabel 2.5 Top 10 agrarische exportproducten van Nederland naar waarde (op GN 4-digitniveau)

\begin{tabular}{|c|c|c|c|c|c|}
\hline & 2000 & 2005 & 2010 & 2015 & 2020 \\
\hline 1 & Sigaretten & Sigaretten & Snijbloemen & Snijbloemen & $\begin{array}{l}\text { (Kamer)planten en } \\
\text { stekken }\end{array}$ \\
\hline 2 & Snijbloemen & Snijbloemen & $\begin{array}{l}\text { (Kamer)planten en } \\
\text { stekken }\end{array}$ & $\begin{array}{l}\text { (Kamer)planten en } \\
\text { stekken }\end{array}$ & Snijbloemen \\
\hline 3 & Kaas en wrongel & $\begin{array}{l}\text { (Kamer)planten en } \\
\text { stekken }\end{array}$ & Sigaretten & Kaas en wrongel & Kaas en wrongel \\
\hline 4 & $\begin{array}{l}\text { (Kamer)planten en } \\
\text { stekken }\end{array}$ & Kaas en wrongel & Kaas en wrongel & $\begin{array}{l}\text { Ov. prod. voor } \\
\text { menselijke cons. }\end{array}$ & Diervoerders \\
\hline 5 & Varkensvlees & Rundvlees & Diervoerders & Diervoerders & $\begin{array}{l}\text { Ov. prod. voor } \\
\text { menselijke cons. }\end{array}$ \\
\hline 6 & Rundvlees & Diervoerders & Rundvlees & Babyvoeding & Babyvoeding \\
\hline 7 & Bier van mout & Bier van mout & Pluimveevlees & Pluimveevlees & Varkensvlees \\
\hline 8 & Diervoerders & Varkensvlees & $\begin{array}{l}\text { Ov. prod. voor } \\
\text { menselijke cons. }\end{array}$ & Rundvlees & Pluimveevlees \\
\hline 9 & Pluimveevlees & Pluimveevlees & Ov. verse groenten & Varkensvlees & Zaden \\
\hline 10 & Melk en room & $\begin{array}{l}\text { Ov. prod. voor } \\
\text { menselijke cons. }\end{array}$ & Varkensvlees & Bier van mout & Rundvlees \\
\hline
\end{tabular}

Bron: Comtrade, bewerking Wageningen Economic Research.

Er zijn verschillende redenen waarom ook deze producten door Nederland worden geïmporteerd. Zo heeft Nederland een grote verwerkings- en voedingsindustrie, en is Nederland met zijn zeehavens en vliegvelden en spoorwegen een logistiek draaipunt voor heel Europa. Daarnaast importeert Nederland producten om aan de behoeften van consumenten in Nederland (en met name de EU) te voldoen. Denk hierbij aan het Franse kaasje bij een glas wijn of een avocado in een salade of op brood. Soms speelt ook het teeltseizoen mee, waardoor er op de binnenlandse markt onvoldoende producten beschikbaar zijn om aan de vraag te voldoen. Daarnaast is sprake van een internationale markt waarbij concurrentie een rol speelt.

Tabel 2.6 Top 10 agrarische importproducten naar waarde van Nederland (op GN 4-digitniveau)

\begin{tabular}{|c|c|c|c|c|c|}
\hline & 2000 & 2005 & 2010 & 2015 & 2020 \\
\hline 1 & Sojabonen & Sojabonen & Perskoeken & Cacaobonen & Cacaobonen \\
\hline 2 & Melk en room & Hout & Cacaobonen & Sojabonen & $\begin{array}{l}\text { ov prod. voor } \\
\text { menselijke cons. }\end{array}$ \\
\hline 3 & Hout & Melk en room & Sojabonen & Palmolie & Palmolie \\
\hline 4 & Vruchtensap & Wijn & Palmolie & Rundvlees & Sojabonen \\
\hline 5 & Wijn & Cacaobonen & Vruchtensap & Perskoeken & $\begin{array}{l}\text { Onder andere } \\
\text { avocado's, ananassen } \\
\text { en mango's }\end{array}$ \\
\hline 6 & Ruwe tabak & Rundvlees & Rundvlees & Vruchtensap & Diervoerders \\
\hline 7 & Cacaobonen & Perskoeken & Wijn & Wijn & Wijn \\
\hline 8 & Tarwe en mengkoren & Palmolie & Tarwe en mengkoren & $\begin{array}{l}\text { ov prod. voor } \\
\text { menselijke cons. }\end{array}$ & Brood, koekjes, biscuits \\
\hline 9 & Snijbloemen & Vruchtensap & Citrusvruchten & Kaas en wrongel & Kaas en wrongel \\
\hline 10 & Diervoeders & Citrusvruchten & Hout & Tarwe en mengkoren & Rundvlees \\
\hline
\end{tabular}

Bron: Comtrade, bewerking Wageningen Economic Research. 


\subsection{Verdiensten in binnen- en buitenland}

Deze paragraaf gaat in op de Nederlandse verdiensten ${ }^{20}$ dankzij de afzet van landbouwgoederen door Nederlandse bedrijven voor de periode 2015-2020. Daarbij zijn buitenlandse afzet (export) en binnenlandse afzet onderscheiden. Verdiensten aan afzet betreffen niet enkel de toegevoegde waarde van de Nederlandse productie van landbouwgoederen, maar ook de verdiensten van Nederlandse bedrijven uit de handel in landbouwgoederen. Er wordt gekeken naar het totaalbeeld en daarmee naar alle bedrijfstakken die in Nederland profiteren van de afzet van landbouwgoederen in binnen- en buitenland, inclusief dienstensectoren die indirect en in beperkte mate profiteren van de opbrengsten.

De relevantie van deze data betreft onder andere de verdeling binnenland/buitenland. Nederland is in het laatste decennium uitgegroeid tot de tweede landbouwexporteur ter wereld, ${ }^{21}$ maar vooral sinds het begin van de stikstofcrisis (medio 2019) wordt er nagedacht over minder productie voor de export vanwege bijvoorbeeld een dreigend overschot aan mest, stikstof, $\mathrm{CO}_{2}$ of afval. Export versterkt het verdien- en innovatievermogen, maar een te grote exportoriëntatie kan verduurzaming van de landbouw in de weg zitten (Zwarts, 2020). Zo is de stikstofuitstoot per hectare bijna vier keer hoger dan Europees gemiddeld en wordt de uitstoot voor $46 \%$ door de landbouw veroorzaakt, met name door een grote ammoniakuitstoot in de landbouwsector (TNO, 2019; RIVM, 2020).

Daarbij past wel de nuance dat het verminderen van nationale emissies door eenzijdig te sturen op productie ertoe kan leiden dat emissies zich naar het buitenland verplaatsen (PBL, 2021). Een tweede nuance is dat Nederland zelfs zonder te exporteren niet genoeg landbouwgrond heeft voor het huidige consumptiepatroon. Het landgebruik voor de Nederlandse voedselconsumptie lag in 2017 namelijk anderhalf maal hoger dan het gehele agrarische areaal in Nederland (CLO, 2020). Aan de andere kant is het ook waar dat meer dan de helft van het Nederlandse landbouwareaal is bestemd voor de export (PBL, 2020). Het blijft dan ook van groot belang om de Nederlandse landbouwproductie, voor zowel binnen- als buitenland, in balans te houden met natuur en leefomgeving, zoals het ook de inzet is in de transitie naar kringlooplandbouw (LNV, 2019). Nederland kan zich daarnaast nog meer toeleggen op het exporteren van kennis, innovatie en technologie en daarmee een belangrijke bijdrage leveren aan het toekomstbestendig maken van de voedselproductie elders en ook de Nederlandse vooraanstaande economische positie behouden (ESB, 2020; EZK, 2016).

\section{Export en binnenlandse afzet}

In 2020 verdiende Nederland 70,8 mld. euro (8,9\% van het bbp; al jaren tussen de 8,5 en 9\%) aan de afzet van landbouwgoederen waarvan 42,5 mld. dankzij export en 28,3 mld. door binnenlandse afzet (figuur 2.17). Dat betekent dat $60 \%$ van de totale landbouwverdiensten in Nederland aan de export te danken was. Dat is een lager percentage dan in de jaren ervoor, met name in vergelijking met 2019. In 2019 was het exportaandeel nog 62,6\%. De exportverdiensten bleven ongeveer gelijk, maar de binnenlandse afzet nam sterk toe. In het coronajaar 2020 heeft de export het lastig gehad om door te groeien, terwijl de focus op lokale verkoop groter is geworden. Bij vrijwel alle landbouwgoederen is er een toenemende binnenlandse afzet tussen 2019 en 2020 . Ook bij niet-landbouwgoederen zien we overwegend een afnemend aandeel van de export in de totale Nederlandse productverdiensten (CBS, 2021e).

Voor het overgrote deel betreffen de exportverdiensten landbouwexport van Nederlandse makelij. De wederuitvoerverdiensten zijn gering: ${ }^{22}$ het exportaandeel ligt zonder wederuitvoer circa 2 procentpunt per jaar lager. In 2020 ging het om 58,1\% (export van Nederlandse makelij) in plaats van 60,0\% (inclusief wederuitvoer). In de volgende paragrafen is de export exclusief wederuitvoer (zie ook voetnoot 24).

\footnotetext{
${ }^{20}$ Het concept verdiensten is ongeveer gelijk aan het concept van toegevoegde waarde, maar het is inclusief het saldo van productgebonden belastingen en subsidies. Het voordeel van het gebruiken van verdiensten ten opzichte van toegevoegde waarde is dat er een zuiver aandeel van het bbp gegeven kan worden.

${ }^{21}$ De enorm hoge landbouwexport van Nederland (zie verder paragraaf 2.4) is onder andere te verklaren door een eveneens zeer grote landbouwimport: circa 70\% van de Nederlandse landbouwimport komt uiteindelijk terecht in het buitenland. Dit betreft zowel directe stromen (wederuitvoer en doorvoer) als indirecte stromen (invoer die in Nederland wordt verwerkt tot nieuwe producten die vervolgens worden uitgevoerd naar het buitenland).

22 De totale verdiensten aan de wederuitvoer van landbouwgoederen zijn gering omdat per euro gereëxporteerd landbouwgoed de Nederlandse verdiensten circa 6 keer lager liggen dan bij de export van een in Nederland geproduceerd landbouwproduct. Daarnaast zijn de wederuitvoerverdiensten gering, omdat de landbouw relatief weinig wederuitvoer kent (in vergelijking met nietlandbouwgoederen). Wederuitvoer heeft een aandeel heeft van slechts $8 \%$ in de exportverdiensten, een aandeel van $27 \%$ in de bruto-exportwaarde van landbouwgoederen en $49 \%$ bij niet-landbouwgoederen.
} 


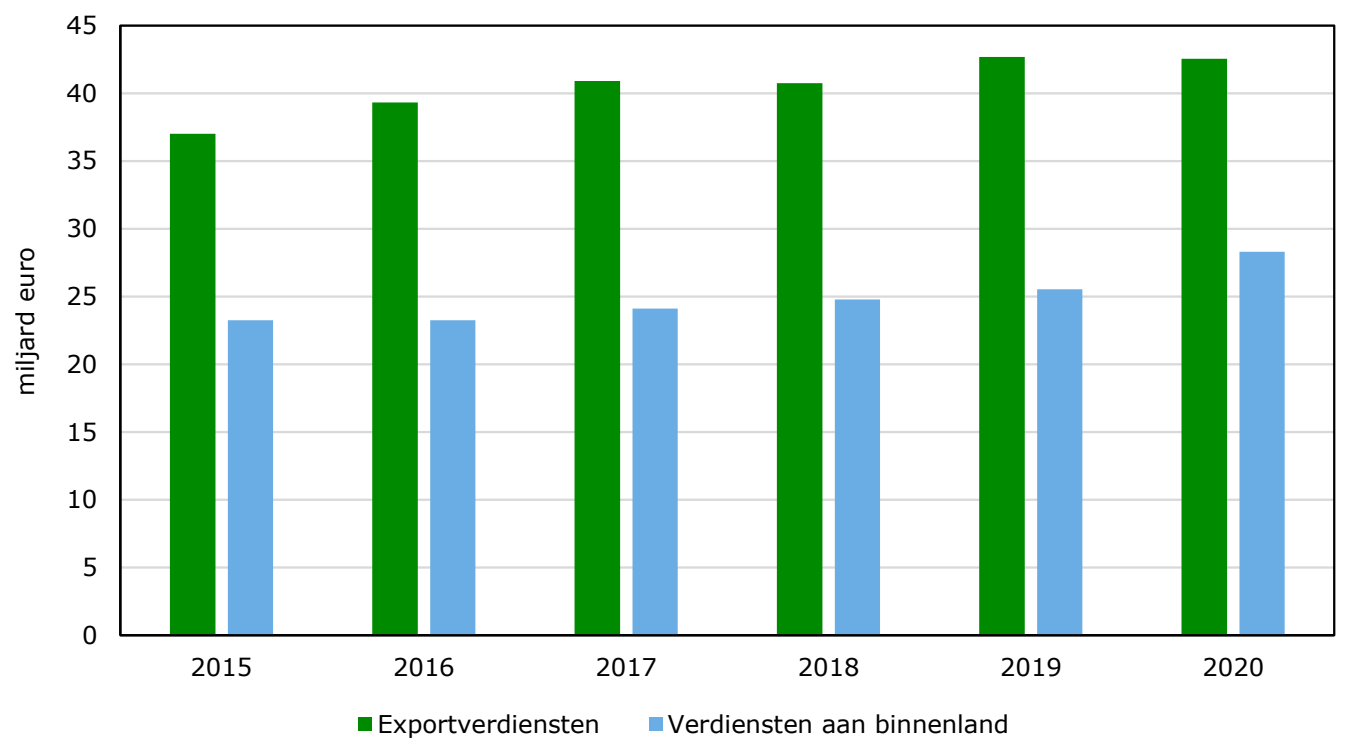

Figuur 2.17 Verdiensten aan export en binnenlandse afzet van landbouwgoederen Bron: $C B S$.

\section{Binnenlandse afzet specifieke landbouwgoederen}

De grootste toenames (zowel 2015-2020 als 2019-2020) in de verdiensten aan binnenlandse afzet betreffen vlees, zuivel, brood(producten), wijn/sterke drank en fruit. Deze producten staan ook hoog genoteerd in de top 10 van binnenlandse landbouwverdiensten qua absolute omvang ${ }^{23}$ (zie figuur 2.18). Vlees met 4,1 mld. euro, brood(producten) met 3,7 mld. euro en zuivel met 2,9 mld. euro staan het hoogst genoteerd. Daarna volgen drie productgroepen die te maken hebben met groente en fruit en deze groepen bij elkaar opgeteld komen hoger uit dan zuivelproducten (3,3 mld. euro). Wijn en sterke drank, diervoeders en sierteeltproducten completeren de top tien.

Figuur 2.18 laat zien dat de toename van de binnenlandse verdiensten in de periode 2019-2020 hoger lag dan de toename in de vier jaar ervoor (2015-2019). Dat geldt voor vlees, brood(producten) en zuivel, maar ook voor fruit en wijn/sterke drank. Dat komt overeen met eerdere publicaties over de omzetten van winkels in voeding (CBS, 2021f). Zo behaalde de foodsector van supermarkten en speciaalzaken in 2020 de grootste omzetgroei van deze eeuw (6,9\% groei, waarbij supermarkten 7,1\%), terwijl de non-foodsector nagenoeg hetzelfde heeft omgezet als in 2019. De foodsector lijkt daarmee meer voor- dan nadeel te hebben gehad van het eerste coronajaar.

\footnotetext{
${ }^{23}$ De rangschikking is afhankelijk van de precieze productindeling en deze is weer afhankelijk van datamogelijkheden. Bij deze data waarbij export en binnenlandse afzet met elkaar vergeleken worden is de basis aanbod- en gebruiktabellen van de nationale rekeningen en dit bepaalt de goederenindeling. Bij de jaarlijkse publicatie over exportverdiensten (zonder binnenlandse afzet) kan worden uitgegaan van de indeling van het geharmoniseerd systeem (goederenhoofdstukken) door koppeling met data over de internationale handel in goederen. Vanwege dit verschil in systematiek is er een iets afwijkende productindeling.
} 


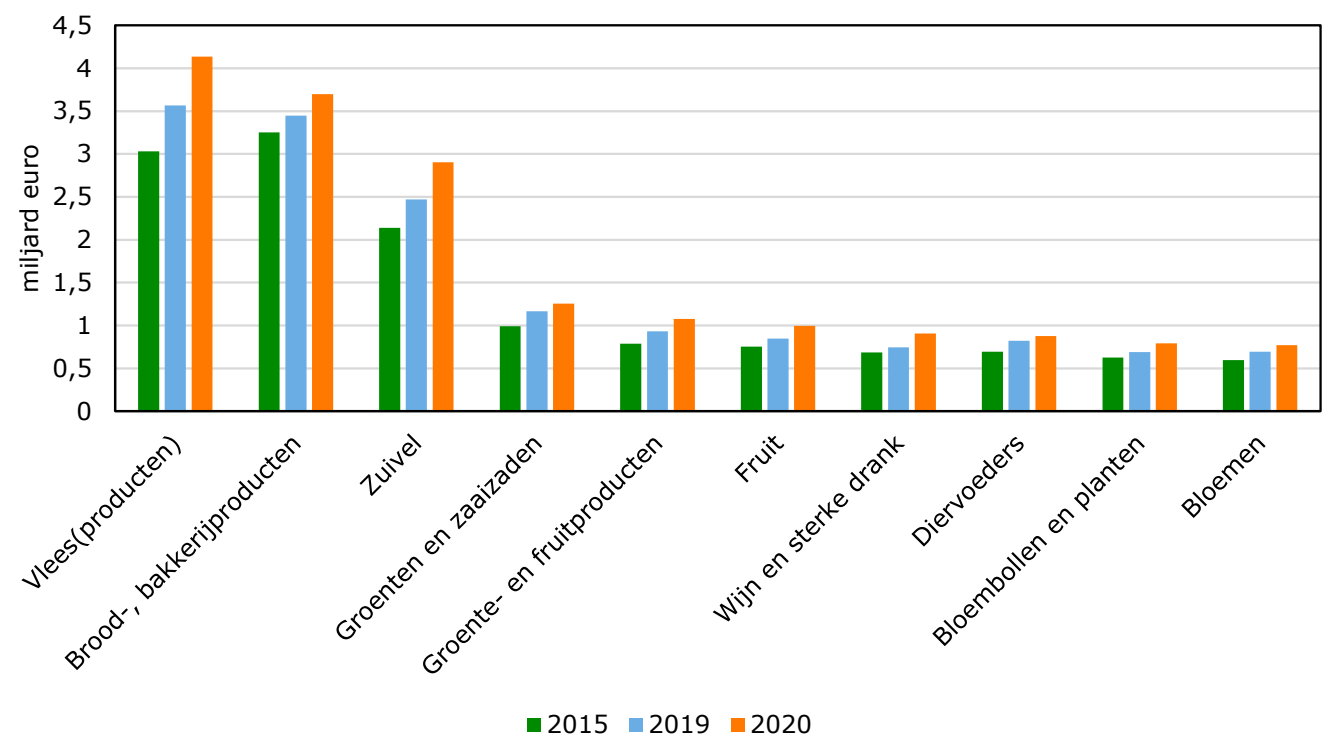

Figuur 2.18 Verdiensten aan binnenlandse afzet landbouwgoederen (top tien 2020) Bron: $C B S$.

\section{Exportverdiensten specifieke landbouwgoederen}

Figuur 2.19 laat een vergelijkbaar overzicht zien, maar nu voor de exportkant. ${ }^{24}$ Vlees, zuivel en groenten hebben nu ook een toppositie. Bloemen, bloembollen en planten staan vanwege hun sterke exportoriëntatie hoger in de top tien dat het geval was bij de binnenlandse afzet in figuur 2.18. Ook cacaoproducten, oliën, vetten, veekoek, bier en aardappelproducten zijn belangrijk in de Nederlandse export. Producten die nu niet in de top tien staan zijn broodproducten en fruit. Dat zijn producten waarvan Nederland zelf relatief weinig voor de export produceert. Broodproducten worden met name voor het binnenland geproduceerd en fruit bovengemiddeld veel uit het buitenland gehaald voor consumptie in binnen- en buitenland.

Een vergelijking tussen de periode 2015-2019 met 2019-2020 levert een heel ander beeld op dan we zagen bij de ontwikkeling van de binnenlandse afzetverdiensten. Enkel bij de productgroep oliën, vetten en veekoek en de bierexport heeft de eenjaarsperiode een positievere ontwikkeling laten zien dan de vier jaar ervoor. Voor vijf van de tien producten in de top tien zijn de exportverdiensten in het coronajaar 2020 afgenomen. Dat betreft zuivel, vlees, cacaoproducten en aardappelproducten, mogelijk verband houdend met de sluiting van de buitenlandse horeca. Bij de overige vijf is er een lichte toename. Het laat wederom zien dat de export het in coronajaar 2020 moeilijk had, terwijl de binnenlandse afzet stevig doorgroeide.

\footnotetext{
${ }^{24}$ Vanaf deze paragraaf gaat het wat betreft de export op productniveau enkel over de export van Nederlandse makelij, dus exclusief de (geringe) verdiensten aan wederuitvoer van landbouwgoederen. Er zijn namelijk geen data beschikbaar over wederuitvoerverdiensten op het productniveau waarover data beschikbaar zijn over de verdiensten van binnenlandse afzet.
} 


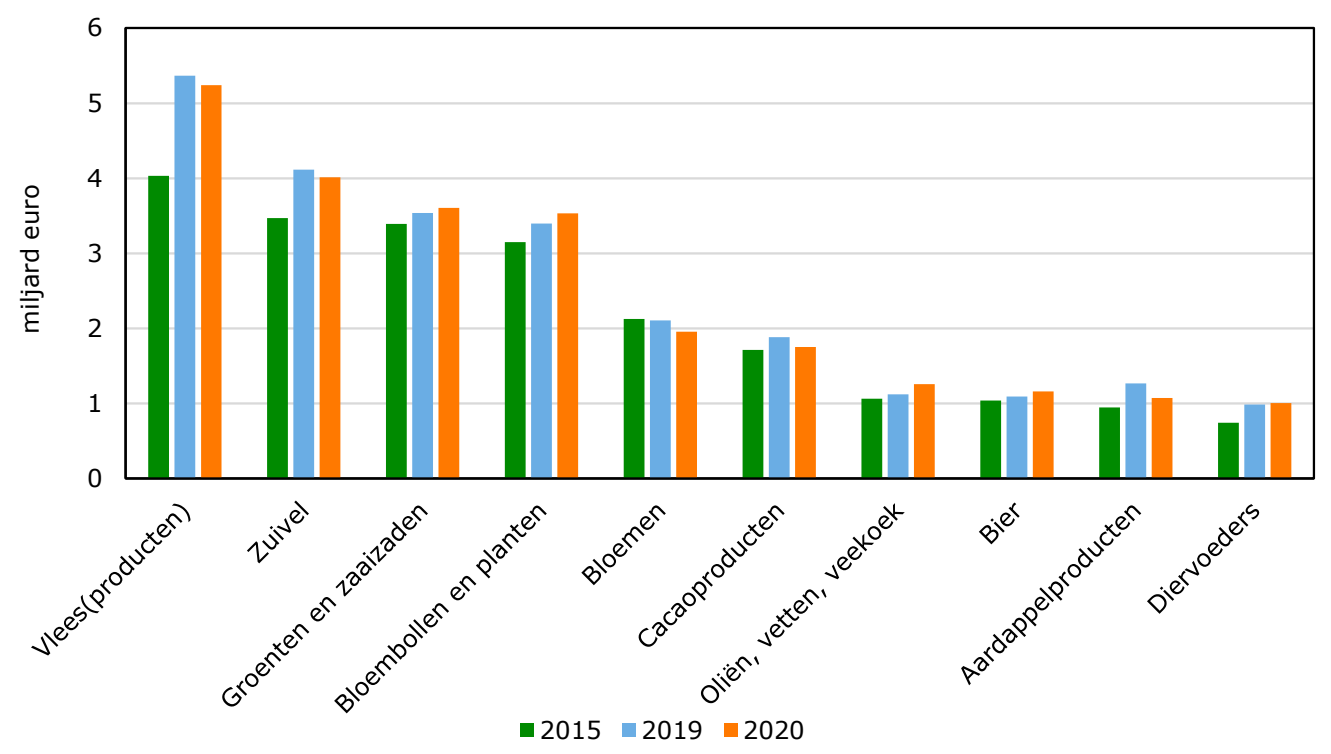

Figuur 2.19 Verdiensten aan export Nederlandse landbouwgoederen (top tien 2020) Bron: $C B S$.

\section{Exportoriëntatie landbouwgoederen}

Door export en binnenlandse afzet per productgroep tegen elkaar af te zetten, kan worden bezien in hoeverre de afzet van specifieke landbouwgoederen exportgericht is. Tabel 2.7 toont de exportoriëntatie van de landbouwgoederen waaraan Nederland het meest verdient (zowel binnenlandse als buitenlandse afzet). Daarbij zitten vlees en zuivel rond of iets onder het gemiddelde van de totale landbouw (58\% in 2020). De afzet van groenten en zaaizaden vindt vooral in het buitenland plaats (74\%) en dat geldt juist niet voor brood en bakkerijproducten: slechts $21 \%$ van de totale afzet betreft verdiensten uit buitenlandse afzet. De goederen op plek 5 tot en met 8 zijn juist wel weer sterk op de export georiënteerd. Zo zijn de verdiensten aan bloembollen en planten voor $82 \%$ te danken aan export, bij bloemen is dat $72 \%$ en bij cacaoproducten $71 \%$. Verderop in de lijst zijn groente- en fruitproducten, diervoeders, fruit en niet-alcoholische dranken beneden gemiddeld op de export gericht, terwijl aardappelproducten, bier, oliën/vetten/veekoek dan weer bovengemiddeld voor het buitenland bestemd zijn.

Eerder is al getoond dat de exportoriëntatie van de landbouw in 2015 (60\%) iets hoger lag dan in 2020 en dat dat verband houdt met de uitbraak van de coronapandemie eind 2019. In 2019 lag het exportaandeel nog op bijna $62,6 \%$. Met name vlees, zuivel en bloemen werden in het coronajaar 2020 relatief minder afgezet in het buitenland dan in het pre-coronajaar 2019. De exportgerichtheid van vlees in 2020 is wel vergelijkbaar met 2015. Het verschil voor bloemen is wel groot. Het exportaandeel in de totale Nederlandse verdiensten aan bloemen is afgenomen van $78 \%$ in 2015 tot $75 \%$ in 2019 en $72 \%$ in 2020 . Voor 2020 geldt dat de exportverdiensten onder druk stonden als gevolg van onder andere een afnemende vraag in het buitenland en toegenomen luchtvrachtkosten (Jukema et al., 2020). 
Tabel 2.7 Exportoriëntatie landbouwgoederen (verdiensten in $\mathrm{m} / \mathrm{n}$. euro)

\begin{tabular}{|c|c|c|c|c|c|c|}
\hline & $\begin{array}{r}\text { Verdiensten } \\
2020\end{array}$ & w.v. export & $\begin{array}{r}\text { Verdiensten } \\
2019\end{array}$ & w.v. export & $\begin{array}{r}\text { Verdiensten } \\
2015\end{array}$ & w.v. export \\
\hline Vlees(producten) & 9.375 & $56 \%$ & 8.934 & $60 \%$ & 7.062 & $57 \%$ \\
\hline Zuivel & 6.914 & $58 \%$ & 6.585 & $62 \%$ & 5.609 & $62 \%$ \\
\hline Groenten en zaaizaden & 4.859 & $74 \%$ & 4.702 & $75 \%$ & 4.382 & $77 \%$ \\
\hline Brood-, bakkerijproducten & 4.689 & $21 \%$ & 4.447 & $22 \%$ & 4.003 & $19 \%$ \\
\hline Bloembollen en planten & 4.323 & $82 \%$ & 4.085 & $83 \%$ & 3.778 & $83 \%$ \\
\hline Bloemen & 2.726 & $72 \%$ & 2.796 & $75 \%$ & 2.721 & $78 \%$ \\
\hline Cacaoproducten & 2.461 & $71 \%$ & 2.596 & $73 \%$ & 2.456 & $70 \%$ \\
\hline Groente- en fruitproducten & 1.984 & $46 \%$ & 1.802 & $48 \%$ & 1.562 & $50 \%$ \\
\hline Diervoeders & 1.879 & $53 \%$ & 1.805 & $55 \%$ & 1.436 & $52 \%$ \\
\hline Aardappelproducten & 1.763 & $61 \%$ & 1.890 & $67 \%$ & 1.459 & $65 \%$ \\
\hline Bier & 1.734 & $67 \%$ & 1.564 & $70 \%$ & 1.471 & $71 \%$ \\
\hline Oliën, vetten, veekoek & 1.709 & $74 \%$ & 1.514 & $74 \%$ & 1.392 & $77 \%$ \\
\hline Fruit & 1.609 & $38 \%$ & 1.343 & $37 \%$ & 1.169 & $36 \%$ \\
\hline Niet-alcoholische dranken & 1.284 & $50 \%$ & 1.177 & $51 \%$ & 1.113 & $47 \%$ \\
\hline Overige landbouwgoederen & 20.318 & $57 \%$ & 19.643 & $59 \%$ & 17.984 & $57 \%$ \\
\hline Totaal (excl. wederuitvoer) & 67.626 & $58 \%$ & 64.885 & $61 \%$ & 57.596 & $60 \%$ \\
\hline
\end{tabular}

Bron: CBS.

\section{Werkgelegenheid}

Export en binnenlandse afzet leveren niet alleen opbrengsten op voor de Nederlandse economie, maar ook werkgelegenheid. Op basis van waardeketenanalyse kan het CBS schatten hoeveel arbeidsjaren de verschillende landbouwproducten aan werkgelegenheid opleveren. Voor 2020 wordt uitgegaan van 776 duizend arbeidsjaren die kunnen worden gelinkt aan de afzet van landbouwgoederen (inclusief wederuitvoer) (figuur 2.20). Daarbij gaat het zowel om een directe bijdrage (arbeidsjaren in de exporterende bedrijfstakken) als indirect (in de toeleverende bedrijfstakken). Dat komt overeen met 10,0\% van de totale werkgelegenheid in Nederland. Het percentage schommelt al jaren tussen de 9,5 en 10\% (in 2015 was het $9,8 \%$ en in 2019 9,5\%). Eerder zagen we een iets lager percentage bij de geldopbrengsten (de landbouwafzet is goed voor $8,9 \%$ van het bbp). Dat betekent dat er per eenheid output bovengemiddeld veel mensen werkzaam zijn voor de afzet van landbouwgoederen.

Het exportaandeel ligt bij de werkgelegenheid significant lager dan bij de verdiensten in de periode 20152020. Zo was in 2020 53,7\% van de totale agrarische werkgelegenheid exportgerelateerd terwijl het exportaandeel bij de verdiensten in dat jaar op 60,0\% lag. Dat heeft te maken met heterogeniteit tussen bedrijven, zoals verschillen in bedrijfsgrootte en bedrijfsactiviteit. Exporterende bedrijven in de landbouwketen zijn gemiddeld genomen productiever dan lokale bedrijven omdat ze door bedrijfsgrootte of kapitaal meer kunnen profiteren van innovatie, schaalvergroting en mechanisatie (CBS, 2017a). Daardoor is er per eenheid output minder arbeid nodig. Ook na controle voor heterogeniteit geldt echter dat exporterende bedrijven gemiddeld productiever zijn dan niet-exporterende bedrijven wat te maken heeft met bijvoorbeeld selectie-effecten (productieve bedrijven zijn eerder geneigd te exporteren dan minder productieve bedrijven; CBS, 2013). 


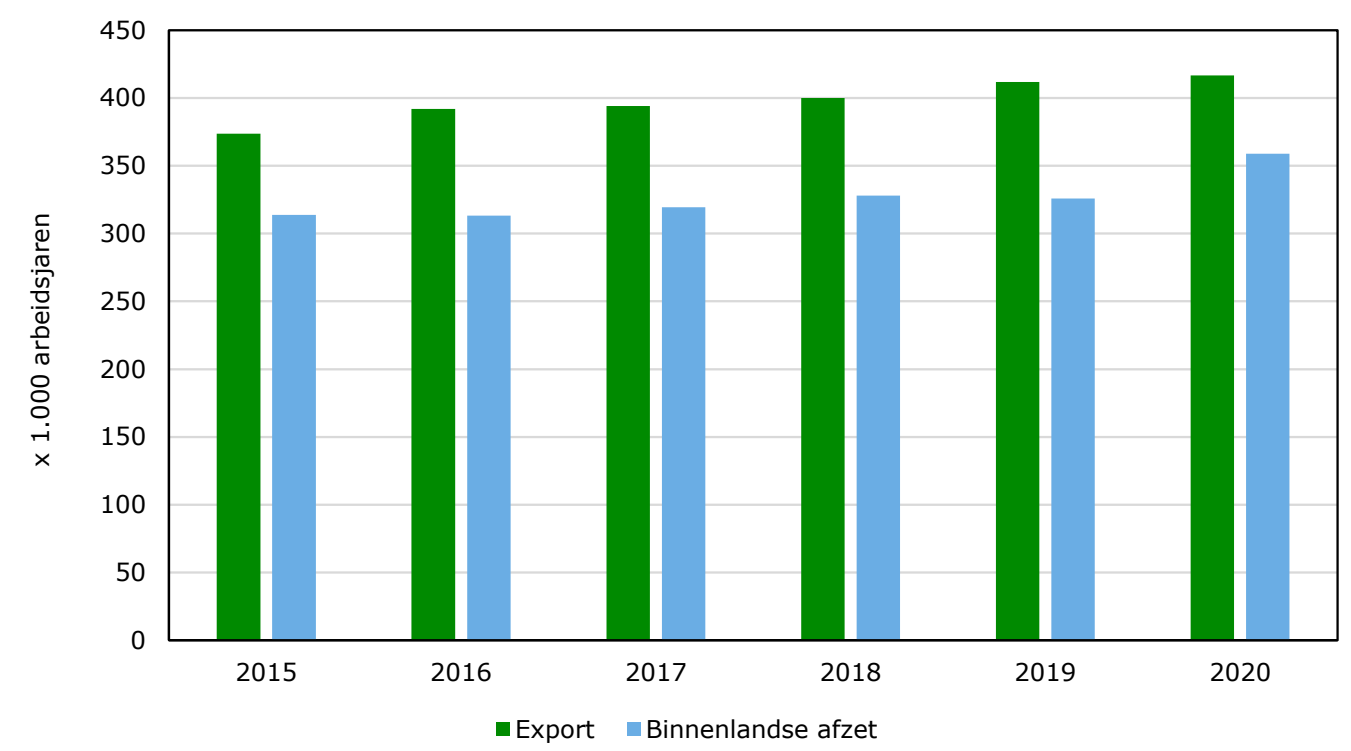

Figuur 2.20 Werkgelegenheid in Nederland dankzij afzet van landbouwgoederen Bron: $C B S$.

Figuur 2.21 laat voor de belangrijkste landbouwgoederen (in termen van totale verdiensten) de exportaandelen voor het jaar 2020 zien voor zowel verdiensten als werkgelegenheid. Er is een logisch patroon zichtbaar van goed vergelijkbare exportaandelen op productniveau. Daarnaast valt op dat de exportaandelen in werkgelegenheid bij alle gepresenteerde goederen iets lager liggen dan het geval is voor exportaandelen in termen van verdiensten. Daarbij zijn er wel verschillen tussen de verschillende saldi. Landbouwproducten waarbij grootschalige (productieve) productie voor de export plaatsvindt zijn over het algemeen goederen waar het exportaandeel in de verdiensten hoger ligt dan het exportaandeel in de werkgelegenheid. Dat geldt met name voor vlees, zuivel, cacaoproducten, diervoeders, aardappelproducten, bier, oliën/vetten/veekoek en niet-alcoholische dranken.

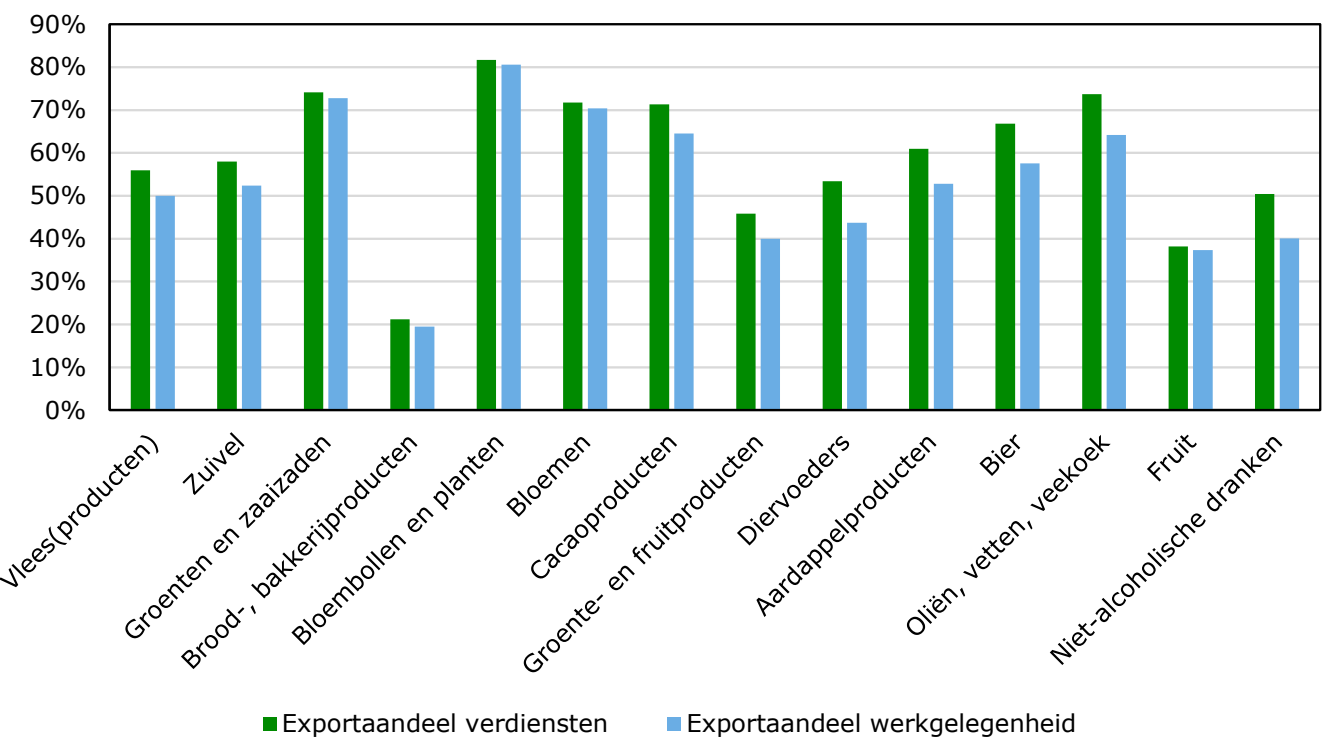

Figuur 2.21 Exportaandelen in verdiensten en werkgelegenheid, 2020 Bron: $C B S$. 


\section{Voedselconsumptie}

\section{$3.1 \quad$ Inleiding}

Dit hoofdstuk gaat in paragraaf 3.2 in op de verkoopkanalen van voedsel. Paragraaf 3.3 geeft inzicht in de uitgaven aan voedsel, waaronder aan voedsel met een duurzaamheidskenmerk. Voedselverspilling komt aan bod in paragraaf 3.4. Het hoofdstuk wordt afgesloten met een beschouwing over het in de markt zetten van betere standaarden voor dierenwelzijn.

\subsection{Verkoopkanalen voedsel}

Grote diversiteit aan verkoopkanalen

Er zijn verschillende vormen van distributie van voedsel aan Nederlandse consumenten. De belangrijkste onderverdeling is naar detailhandel en foodservice. Onder de detailhandel vallen traditionele supermarkten en kleine detailhandel. Supermarkten bundelen het aanbod van een groot aantal producten. Een groot supermarktfiliaal kan wel tot 50 duizend afzonderlijke artikelen verkopen. Onder kleine detailhandel vallen speciaalzaken, ambulante handel en puur online handel in voedingsmiddelen. Speciaalzaken zijn winkels die gericht zijn op de verkoop van artikelen in één of een beperkt aantal gerelateerde productgroepen. Voorbeelden van speciaalzaken zijn viswinkels, kaaswinkels, slagerijen en poeliers, winkels in brood, banket, groenten en fruit, slijterijen, etc. Ook is er online detailhandel van voedingsmiddelen. Ook warenhuizen en drogisterijen verkopen in beperkte mate voedsel.

In de foodservice is een grote diversiteit aan bedrijven actief. De foodservice bestaat uit restaurants, hotels, fastfoodrestaurants, bars, cafés, cafetaria's en lunchrooms, catering (bij bedrijven, instellingen, trein en vliegtuig), voorzieningen in vrijetijdsaccomodaties (sportkantines, (film)theater, dierentuin etc.) en foodservice op tankstations. Foodservice richt zich vooral op het verkopen van bereide maaltijden en ander voedsel voor buitenhuishoudelijk gebruik.

Veel bedrijven in de detailhandel en foodservice richten zich ook op thuisbezorging van boodschappen en maaltijden via online platforms: fooddelivery. De meeste fysieke supermarktformules en veel andere fysieke detailhandel hebben eigen online diensten voor hun assortiment. Daarnaast is er puur online detailhandel zoals online supermarkten en gespecialiseerde online winkels. In de online bezorging van maaltijden zijn er internetportals en -koeriersdiensten actief die de bezorging van maaltijden verzorgen voor foodservicebedrijven. Ook zijn er foodservice-partijen met een eigen bezorgdienst. Online diensten faciliteren ook het afhalen van klaargezette boodschappen en maaltijden op fysieke locaties van winkels en horecagelegenheden.

De grenzen tussen de verkoopkanalen zijn in de loop der jaren minder scherp geworden. Zo hebben detaillisten in de foodsector vaker mogelijkheden om foodservice-activiteiten in hun winkel te ontplooien en op de cateringlocaties worden ook winkelgedeeltes ingericht. Supermarkten verkopen steeds vaker maaltijden, in sommige restaurants kun je ook producten kopen. Soms gaan de initiatieven verder door winkels, horeca en marktkramen te combineren in een zogenoemde 'markthal' of een 'foodhal'.

\section{Veranderingen in verkoopkanalen gaan langzaam}

Supermarkten zijn het belangrijkste afzetkanaal van voedsel, al neemt dit aandeel langzaam af ten gunste van de foodservice. In 2019 werd ongeveer 53\% van de ongeveer 65 mld. euro uitgaven aan voedsel in supermarkten besteed (Voedsel-Economisch Bericht 2020). Bijna 80\% van al het eten en drinken wordt dan ook thuis gegeten (RIVM Voedselconsumptiepeiling 2012-2016). Het tweede belangrijke kanaal was de foodservice met ongeveer 32\% van alle bestedingen aan voedsel in 2019. 
De twee opvallende trends in de periode vóór de coronacrisis waren een steeds belangrijker wordende consumptie van voeding en dranken buitenshuis en de opkomst van online kanalen. De buitenhuishoudelijke consumptie van voeding en dranken is in het laatste decennium met $15 \%$ gestegen. De totale omzet van eten en drinken in de foodservice is gestegen van ruim 18 mld. euro in 2009 naar circa 21 mld. euro in 2019. Het aandeel van de foodservice in de totale omzet van eten en drinken is in het laatste decennium met enkele procenten gestegen. De economische groei na de kredietcrisis in 2008 heeft de populariteit van eten en drinken buitenshuis doen toenemen. Vooral jongere generaties hebben een voorkeur voor een maaltijd buitenshuis.

Online verkoopconcepten hebben eveneens geprofiteerd van een naar gemak strevende consument. De online omzet van de bestaande supermarktformules is tussen 2013 en 2019 toegenomen van circa 240 mln. euro naar ruim 1,4 mld. euro (schattingen Wageningen Economic Research op basis van IGD). Hierbij gaat het om boodschappen en maaltijdboxen. Ook zijn nieuwe puur online supermarktformules (bijvoorbeeld Picknick, Crisp) ontstaan, en maaltijdboxbedrijven (bijvoorbeeld HelloFresh, Marley Spoon) op de markt gekomen. Maar met een totaal aandeel van $4 \%$ was het bezorgen van boodschappen bescheiden ten opzichte van alle uitgaven in de detailhandel (FSIN). De verkoop van online maaltijden was in 2019 met $56 \%$ toegenomen ten opzichte van 2016. In 2019 was de omzet van online boodschappen en maaltijden delivery ongeveer fiftyfifty.

Corona zorgt voor een vraagverschuiving naar de detailhandel en voor een boost voor online In 2020 heeft Covid-19 het landschap van de distributie van voedsel in Nederland veranderd. Tabel 3.1 geeft een overzicht van de omzet aan eten en drinken voor een aantal verkoopkanalen. Een deel van de online service van supermarkten is inbegrepen in de omzetcijfers doordat de rapportage van online en fysieke verkoop niet altijd afzonderlijk plaatsvindt. Andere online verkopen zijn in deze tabel niet opgenomen. De afzet van voedsel in de foodservice is hard getroffen. De totale omzet van voeding in de foodservice bedroeg in 2020 circa 14 mld. euro, een omzetverlies van 37\% in één jaar. Er zijn grote verschillen in hoe de deelsectoren in de foodservice zijn geraakt. Outlets in recreatiefaciliteiten, in tankstations en openbaar vervoer zijn het hardst geraakt ofwel door de verplichte sluiting, ofwel door het wegvallen van de vraag doordat er minder mensen onderweg zijn geweest naar bijvoorbeeld werk. In restaurants, lunchrooms en in de fastfoodservice heeft een deel van de ondernemers het wegvallen van de omzet kunnen beperken met afhaal- en bezorgconcepten. De fastfoodservice heeft daarin een voordeel gehad, omdat het afhalen en bezorgen van maaltijden daar al vóór corona gangbaar was. Daarnaast zijn fastfoodmaaltijden doorgaans goed geschikt voor transport door bezorgers.

De detailhandel heeft van de beperkingen in de foodservice en vraagverschuiving van de consument kunnen profiteren. De bestedingen aan voedsel in supermarkten zijn met $9 \%$ gestegen. Deze bestedingen bedroegen in 2020 ruim 37 mld. euro. De kleine detailhandel in voeding heeft in $20206 \%$ meer omgezet dan in het voorgaande jaar (inclusief non-food).

Tabel 3.1 Omzet eten en drinken in Nederland

\begin{tabular}{|c|c|c|c|}
\hline & 2019 (in mld. euro) & 2020 (in mld. euro) & $\begin{array}{r}\text { Ontwikkeling (\%), } \\
2019-2020\end{array}$ \\
\hline Supermarkten a) & 34,4 & 37,2 & 9 \\
\hline $\begin{array}{l}\text { Speciaalzaken, winkels in natuur-, } \\
\text { buitenlandse en overige voeding b) }\end{array}$ & 6,0 & $6,3 \mathrm{c})$ & 6 \\
\hline Foodservice & 21,9 & 13,7 & -37 \\
\hline - Catering (zelf- en contractcatering) & 3,3 & 2,2 & -32 \\
\hline - Gemak (fastfood, cafetaria, lunchrooms) & 3,0 & 2,4 & -22 \\
\hline - Recreatie (sport, filmhuis, etc.) & 3,6 & 1,8 & -49 \\
\hline $\begin{array}{l}\text { - Onderweg (tankstations, openbaar } \\
\text { vervoer) }\end{array}$ & 2,4 & 1,2 & -49 \\
\hline - Restaurants en hotels & 8,3 & 5,0 & -40 \\
\hline - Zorginstellingen & 1,3 & 1,1 & -13 \\
\hline \multicolumn{4}{|l|}{ n.b. = niet beschikbaar } \\
\hline \multicolumn{4}{|c|}{$\begin{array}{l}\text { a) Een deel van de online service van supermarkten is inbegrepen in de omzetcijfers doordat de rapportage van online en fysieke verkoop niet altijd } \\
\text { afzonderlijk plaatsvindt; b) Inclusief non-food verkopen; c) Schatting voor } 2020 \text { op basis van trend CBS. }\end{array}$} \\
\hline \multicolumn{4}{|c|}{ Bron: CBS (retail) en Foodstep (foodservice). Bewerking: Wageningen Economic Research. } \\
\hline
\end{tabular}


De vraag naar bezorging (via online diensten) is in 2020 door coronamaatregelen flink opgestuwd. Volgens FSIN steeg de markt van fooddelivery in 2020 in één jaar met 53\% naar een recordomzet van 5,9 mld. euro. Boodschappenbezorging was in 2020 met een omzet van 3,1 mld. euro voor het eerst groter dan maaltijdbezorging, 2,8 mld. euro (FSIN).

Aantal bedrijven in de fysieke detailhandel in voeding relatief stabiel, toename online bedrijven Figuur 3.1 geeft het aantal bedrijven weer die actief zijn in de (online) detailhandel in voedingsmiddelen. Het aantal bedrijven met gespecialiseerde winkels (groente, vis, slijterij, kaas, etc.) is het hoogst. Deze bedrijven zijn vaak kleine zelfstandigen, een klein deel opereert als franchisenemer. Tussen 2017 en 2021 is het aantal speciaalzaken gedaald met 260 bedrijven naar 6.150. Markthandelaren vormen wat betreft het aantal bedrijven de één na grootste groep bedrijven in de fysieke detailhandel van voeding met 3.760 bedrijven in 2021. In de supermarktbranche waren in 2019 circa 3.040 bedrijven actief, inclusief franchisenemers van de grote supermarktformules. Tussen 2017 en 2021 schommelde het aantal supermarktbedrijven tussen 3.025 en 3.060. Het grootste deel van de verkopen vindt echter plaats via een beperkt aantal grote supermarktformules. Ten slotte is er een groep fysieke winkels met een algemeen assortiment in natuurvoeding, buitenlandse en overige voeding waarin in 2021 met 2.045 bedrijven actief zijn. De coronacrisis lijkt vooral impact te hebben gehad op de groei van webwinkels in voeding. Het aantal bedrijven is met evenveel toegenomen tussen 2017 en 2020 (van 2.955 naar 4.050) als in 2020 alleen (naar 5.185).

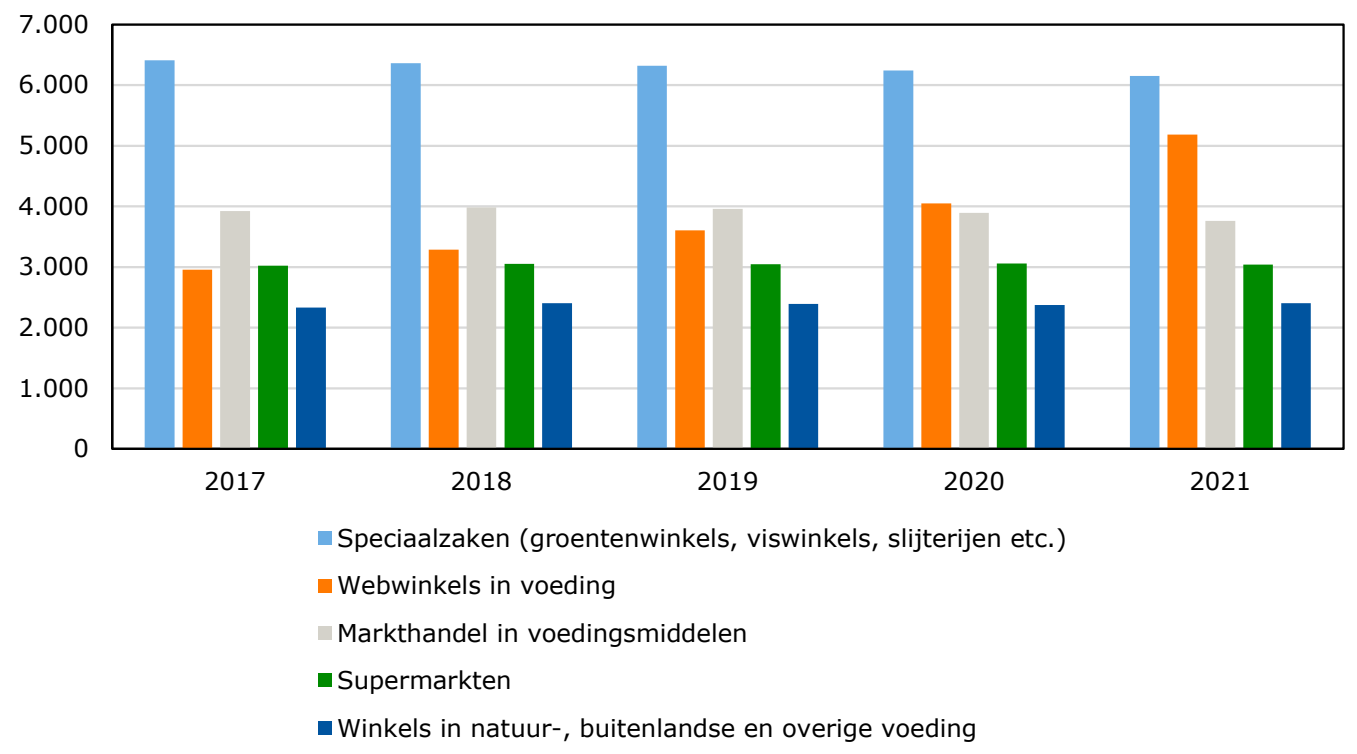

Figuur 3.1 Aantal bedrijven in de detailhandel per branche 2017-2021 (meting in het eerste kwartaal) Bron: CBS Bedrijven per bedrijfstak. Bewerking: Wageningen Economic Research.

Enige concentratie van supermarktformules aan de in- en verkoopkant In Nederland zijn zes grote inkooporganisaties voor supermarkten actief. Deze maken afspraken met leveranciers over de voorwaarden van hun leveringen. De grote supermarktketens van Ahold Delhaize (in Nederland bekend van Albert Heijn en AH formules), Jumbo, Lidl en Aldi kopen zelfstandig in.

Inkoopcombinaties zijn Superunie (met aangesloten kleinere ketens zoals Deen, Spar en Plus) en Van Tol. Supermarkten die gezamenlijk inkopen hebben een sterkere positie op de inkoopmarkt. Naast eten en drinken verkopen supermarkten ook non-foodproducten. Superunie verenigt vooral (maar niet uitsluitend) regionale supermarktketens en vertegenwoordigt een marktaandeel op de inkoopmarkt van supermarkten van ruim $27 \%$.

In Tabel 3.2 staat de omzet inclusief non-food, marktaandelen en aantal winkels van supermarktformules in Nederland in 2019-2020. Deze kengetallen bevatten zowel de eigen winkels als de winkels van franchisenemers. 
Tabel 3.2 Omzet inclusief non-food, marktaandelen en aantal winkels van supermarktformules in Nederland in 2019-2020

\begin{tabular}{|c|c|c|c|c|c|}
\hline \multirow[t]{2}{*}{ Retailorganisatie } & \multirow{2}{*}{$\begin{array}{r}\text { Omzet in mld. } \\
\text { euro } \\
2020\end{array}$} & \multirow{2}{*}{$\begin{array}{r}\text { Aantal } \\
\text { vestigingen } \\
2020 \mathrm{~b} \text { ) }\end{array}$} & \multicolumn{2}{|c|}{$\begin{array}{r}\text { Marktaandelen } \\
(\%)\end{array}$} & \multirow{2}{*}{$\begin{array}{l}\text { Verandering } \\
\text { marktaandeel a) } \\
2019-2020 \\
\end{array}$} \\
\hline & & & 2019 & 2020 & \\
\hline $\begin{array}{l}\text { Ahold Delhaize (Albert Heijn, } \mathrm{AH} \text { to go, } \mathrm{AH} \\
\mathrm{XL}) \mathrm{c} \text { ) }\end{array}$ & 15,3 & 992 & 34,8 & 34,9 & \\
\hline Jumbo Groep (Jumbo) & 9,1 & 679 & 20,9 & 21,5 & \\
\hline Lidl & 4,3 & 432 & 10,7 & 10,7 & \\
\hline Aldi & 2,7 & 496 & 5,9 & 5,5 & \\
\hline Plus & 3,0 & 269 & 6,5 & 6,7 & \\
\hline Detailresult (Dirk en Dekamarkt) & 2,3 & 205 & 5,5 & 5,3 & \\
\hline $\begin{array}{l}\text { Coop (Coop Supercoop, CoopCompact, } \\
\text { Coop Vandaag) }\end{array}$ & 1,6 & 314 & 3,7 & 3,9 & \\
\hline Deen & 0,8 & 80 & 2,0 & 2,0 & 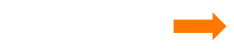 \\
\hline Hoogvliet & 0,9 & 71 & 2,1 & 2,0 & \\
\hline Spar Holding & 0,8 & 236 & 1,2 & 1,2 & \\
\hline Jan Linders & 0,5 & 62 & 1,1 & 1,2 & \\
\hline Poeisz & 0,4 & 69 & 1,0 & 1,0 & \\
\hline
\end{tabular}

a) op basis van niet-afgeronde cijfers; b) Op basis van de meting in de week 53; c) Inclusief Gall \& Gall, Etos en Bol.com.

Bronnen: IGD database, groentennieuws.nl op basis van IRI en Nielsen en eigen schattingen. Bewerking Wageningen Economic Research.

Van de supermarkten staan de formules van Ahold Delhaize, als het gaat om omzet en marktaandeel in Nederland, bovenaan. In 2020 realiseerde Ahold Delhaize een omzet van ruim 13 mld. euro in Nederland. Jumbo is de tweede grote speler met een omzet van ruim 9,1 mld. euro in 2020. De Albert Heijn-formules hebben ongeveer $35 \%$ van de markt in handen, Jumbo heeft bijna $22 \%$. Beide zijn een full-service supermarkt met een breed assortiment artikelen in verschillende prijssegmenten. In de positionering hebben Albert Heijn en Jumbo een eigen accent. De twee Duitse supermarktformules Lidl en Aldi staan op plekken drie en vijf als het gaat om het marktaandeel. Aldi staat bekend als een hard-discounter met een scherp geprijsd assortiment en een beperkt aantal artikelen. Lidl, een hard-discounter van origine, heeft meer het profiel van een basisservice-supermarkt met voordelig assortiment.

Ahold Delhaize heeft de meeste winkels. Albert Heijn, AH to go en $\mathrm{AH} X \mathrm{~L}$ en andere winkeltypen van Ahold Delhaize hebben in 2020 samen 992 vestigingen. Jumbo heeft 679 vestigingen. Aldi heeft met 496 vestigingen de derde positie als het gaat om het aantal vestigingen. Lidl heeft 431 vestigingen.

In de jaren voor corona hebben de grootste supermarkten langzaam aan marktaandeel gewonnen. Dit komt deels door de aankoop van kleinere winkelformules als Emté (in 2018), C1000 (in 2015) en Super de Boer (in 2012). Daarnaast is de harde groei van Lidl opvallend geweest, met een verdubbeling van het marktaandeel tussen 2008 en 2019. Lidl heeft klanten kunnen aantrekken van zowel Aldi (2,6\% aandeeldaling tussen 2008 en 2019) als andere full-service supermarkten (3\% aandeeldaling tussen 2008 en 2019). In 2019 zijn ook fullservice supermarkten zich steeds meer gaan profileren met aanbiedingen en een laaggeprijsd basisassortiment.

In het coronajaar 2020 hebben sommige formules beter ingespeeld op het verschuiven van de vraag naar de detailhandel dan andere als het gaat om het marktaandeel. De twee grootste winkelformules, Albert Heijn en Jumbo, maar ook Plus, Coop, Jan Linders en Poeisz hebben aan aandeel gewonnen. Opvallend is dat deze formules een breed assortiment met relatief veel luxere producten hebben of regionaal opereren waardoor de binding met klanten relatief groot is.

De consolidatie in het supermarktkanaal is in 2020 verder doorgezet. De grootste vier formules hebben samen een iets groter marktaandeel gekregen. In 2020 werd bekend dat de winkels van Deen ( 80 winkels en 
2\% marktaandeel in 2020) door Vomar, Dekamarkt en Albert Heijn zijn overgenomen. In 2021 hebben Plus en Coop een fusie aangekondigd.

\section{Ontwikkelingen in de foodservice lopen uiteen}

Het verloop van het aantal bedrijven en vestigingen in de foodservice is weergegeven in figuur 3.2 en Figuur 3.3. Er is een relatief snelle stijging van het aantal bedrijven in de eventcatering geweest, van circa 8 duizend in 2017 naar ruim 15 duizend in 2021. Ook het aantal bedrijven in de restaurant- en fastfoodbranche neemt toe. In 2017 waren er 13,3 duizend bedrijven in deze branche, in 2021 is dit aantal gestegen naar 14,8 duizend. De stijging is ook zichtbaar in fastfood, van 13 duizend bedrijven in 2017 naar 15 duizend bedrijven in 2021. Opvallend is dat ook in de laatste twee jaar deze stijgingen zijn doorgezet ondanks de coronacrisis. Dit heeft deels te maken met coronasteun van de overheid waardoor minder zaken gestopt zijn. Het aantal cafés is juist gedaald, van 9,7 duizend in 2017 naar 8,8 duizend in 2021. Dit heeft te maken met veranderend consumentengedrag waarbij cafés voor steeds minder mensen een rol spelen als trefpunt voor hun sociale leven. Een lichte daling geldt ook voor het aantal bedrijven in contractcatering (-45), met 1,1 duizend bedrijven de kleinste groep.

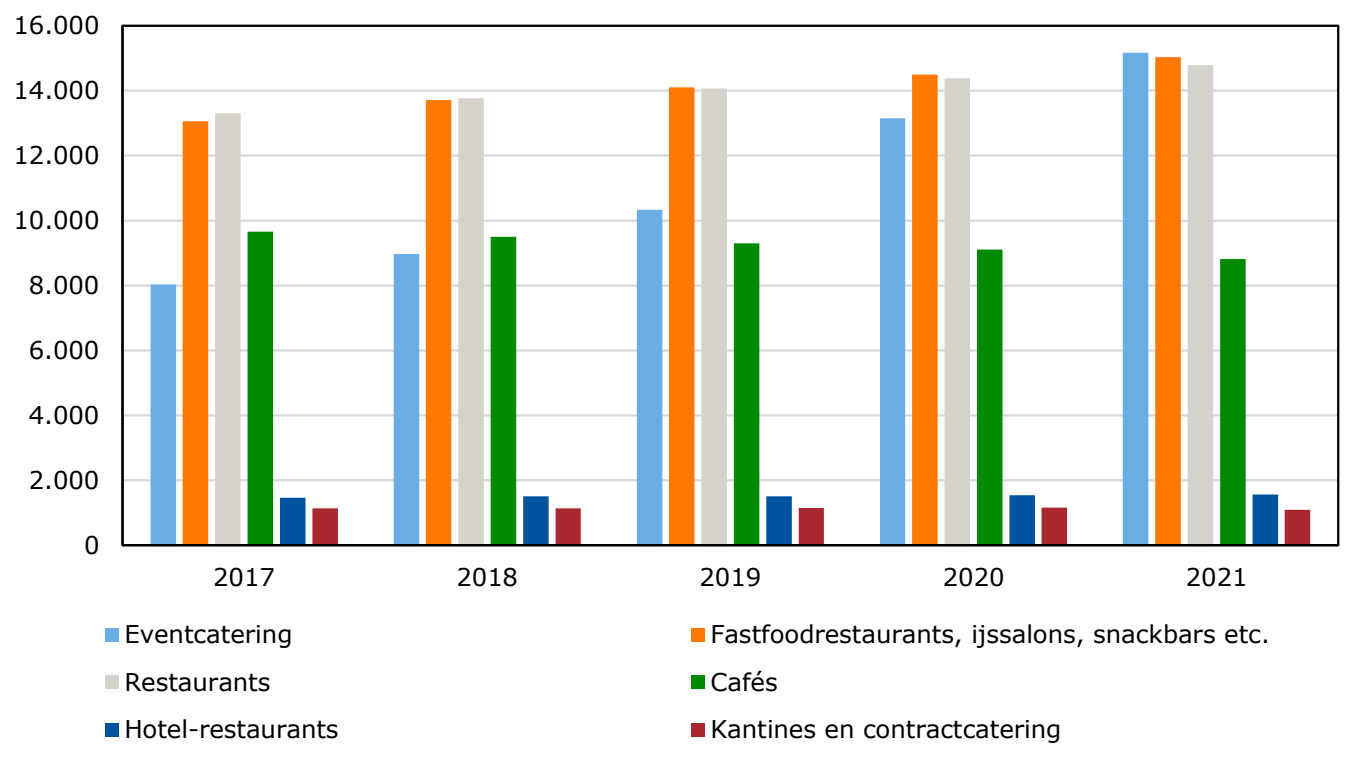

Figuur 3.2 Aantal bedrijven in restaurant- en fastfoodbranche 2017-2021 (meting in het eerste kwartaal) Bron: CBS Bedrijven per bedrijfstak. Bewerking: Wageningen Economic Research.

Catering is zowel in aantallen bedrijven als aantallen vestigingen de grootste branche in de foodservice (zie Figuur 3.2 en Figuur 3). Er zijn ongeveer 106 duizend vestigingen van zelf- en contractcatering. De krimp in de cafébranche is naast het aantal bedrijven ook in het aantal vestigingen zichtbaar: Dranken (cafés, bars) is tussen 2017 en 2019 van 10,2 naar 9,8 duizend vestigingen gegaan. In totaal telde de foodservice in 2019 ruim 174 duizend vestigingen. 


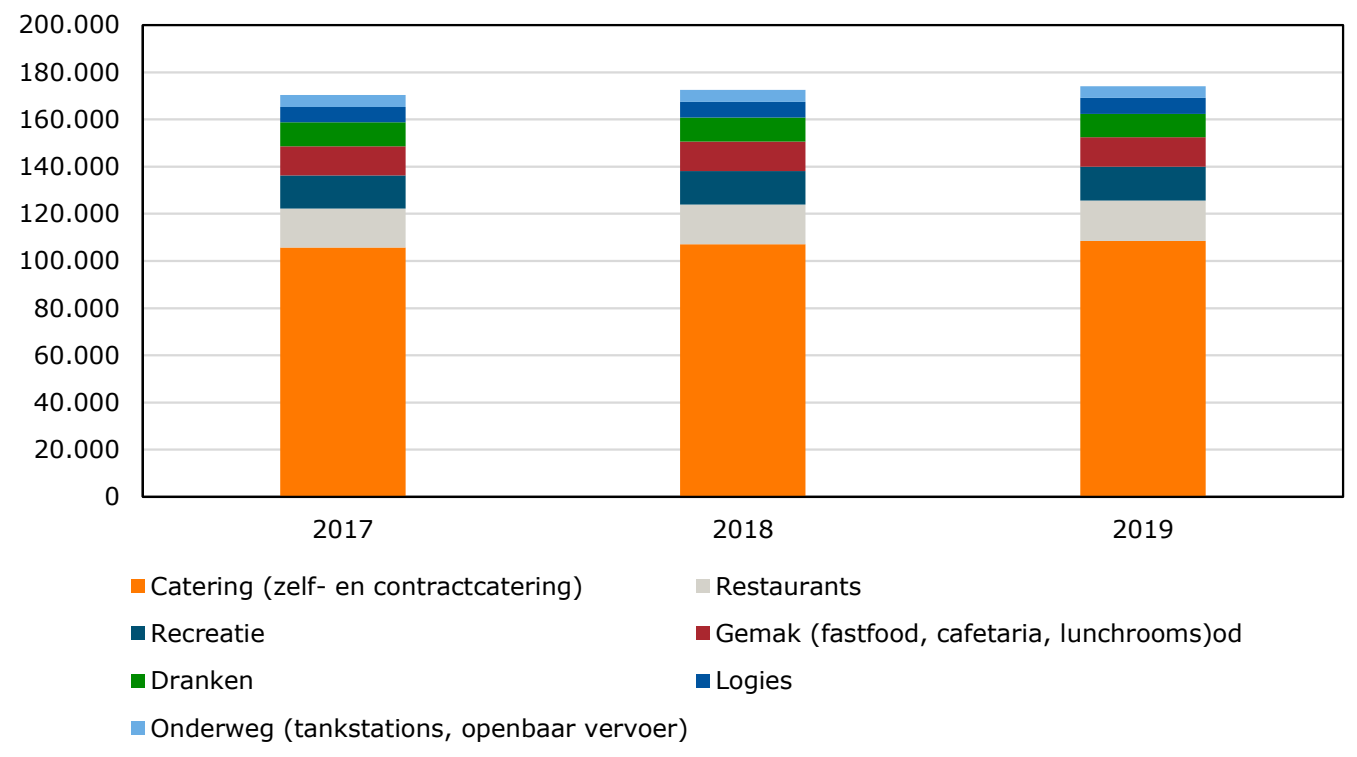

Figuur 3.3 Aantal vestigingen in de foodservice 2017-2019 (meting in het eerste kwartaal) Bron: Foodstep. Bewerking: Wageningen Economic Research.

\subsection{Uitgaven aan voeding}

\subsubsection{Algemeen}

Corona zorgt voor een trendbreuk in consumptieve bestedingen

De totale consumptie van Nederlandse huishoudens was circa $335 \mathrm{mld}$. euro in 2020. Aan voedingsmiddelen en alcoholvrije dranken is ruim 43 mld. euro besteed (Tabel 3). Dit betreft de bestedingen van consumenten in de detailhandel (onder andere supermarkten, speciaalzaken, markten en internetwinkels en nonfoodwinkels) en directe verkoop. De uitgaven aan voedingsmiddelen en alcoholvrije dranken bedroegen $12,7 \%$ van de totale consumptieve bestedingen aan goederen en diensten in 2020 . Uitgaven aan voeding in de horeca en recreatie worden in de uitgaven aan diensten meegerekend en komen in het aandeel van voedingsmiddelen en dranken in de consumptieve bestedingen niet tot uitdrukking.

In de jaren tot aan het coronajaar 2020 waren de totale consumptieve bestedingen aan goederen en diensten, en de bestedingen aan voedingsmiddelen en dranken stijgende. Het aandeel voedingsmiddelen en alcoholvrije dranken was sinds 2012 met ruim 11\% relatief stabiel (Tabel 3). In 2020 is daar verandering in gekomen. De totale bestedingen aan goederen en diensten zijn gedaald. De bestedingen aan voedingsmiddelen en alcoholvrije dranken zijn juist toegenomen. Als resultaat is het aandeel van voedingsmiddelen en alcoholvrije dranken in één jaar met anderhalve procentpunt gestegen. Een belangrijke reden is de verschuiving van voedselaankopen door de coronamaatregelen van de horeca naar de detailhandel die tot uitdrukking komt in de cijfers over consumptieve bestedingen aan voedingsmiddelen en alcoholvrije dranken. Een andere reden is dat de bestedingen aan andere diensten en goederen meer direct zijn beïnvloed door de beperkingen. Ten slotte kent voedsel als basisbehoefte beperktere besparingsmogelijkheden dan veel andere onderdelen van de consumptieve bestedingen.

Tabel 3.3 Consumptieve bestedingen van huishoudens a) (m/d. euro) b), 2016-2020

\begin{tabular}{|c|c|c|c|c|c|}
\hline & 2016 & 2017 & 2018 & 2019 & 2020 d) \\
\hline Totaal consumptieve bestedingen aan goederen en diensten & 316 & 327 & 342 & 354 & 335 \\
\hline Voedingsmiddelen en alcoholvrije dranken c) & 36 & 37 & 38 & 40 & 43 \\
\hline Aandeel (\%) voedingsmiddelen en alcoholvrije dranken & 11,3 & 11,3 & 11,1 & 11,3 & 12,7 \\
\hline
\end{tabular}

a) Betreft de consumptieve bestedingen door huishoudens inclusief instellingen zonder winstoogmerk ten behoeve van huishoudens; b) Tegen werkelijke prijzen; c) Betreft bestedingen van consumenten via de handel of direct. Uitgaven in horeca en catering worden niet meegenomen. Deze vallen onder uitgaven aan diensten; d) Voorlopige cijfers. 
Aandelen verschillende voedingsmiddelen stabiel

In 2020 is $21 \%$ van de bestedingen aan voeding en dranken bestemd voor Aardappelen, groenten en fruit. De groepen Vlees en vleesproducten, en Brood, broodproducten, gebak en banket zijn beide $19 \%$ van deze bestedingen. Het aandeel van Kruidenierswaren, zoetwaren en overig is $18 \%$. Zuivel, eieren, oliën en vetten maken $15 \%$ van de bestedingen aan voeding en dranken uit. De productgroepen Alcoholvrije dranken en Vis hebben de kleinste aandelen, beide goed voor 4\%. De aandelen van de verschillende productgroepen binnen de consumptieve bestedingen aan voedingsmiddelen en dranken zijn relatief stabiel, maar er is een voorzichtige stijging in het aandeel van aardappelen, groeten en fruit waarneembaar sinds 2000 (figuur 3.4). Dit aandeel is een paar procentpunten toegenomen ten koste van andere voedingsmiddelen als vis, vlees en alcoholvrije dranken.

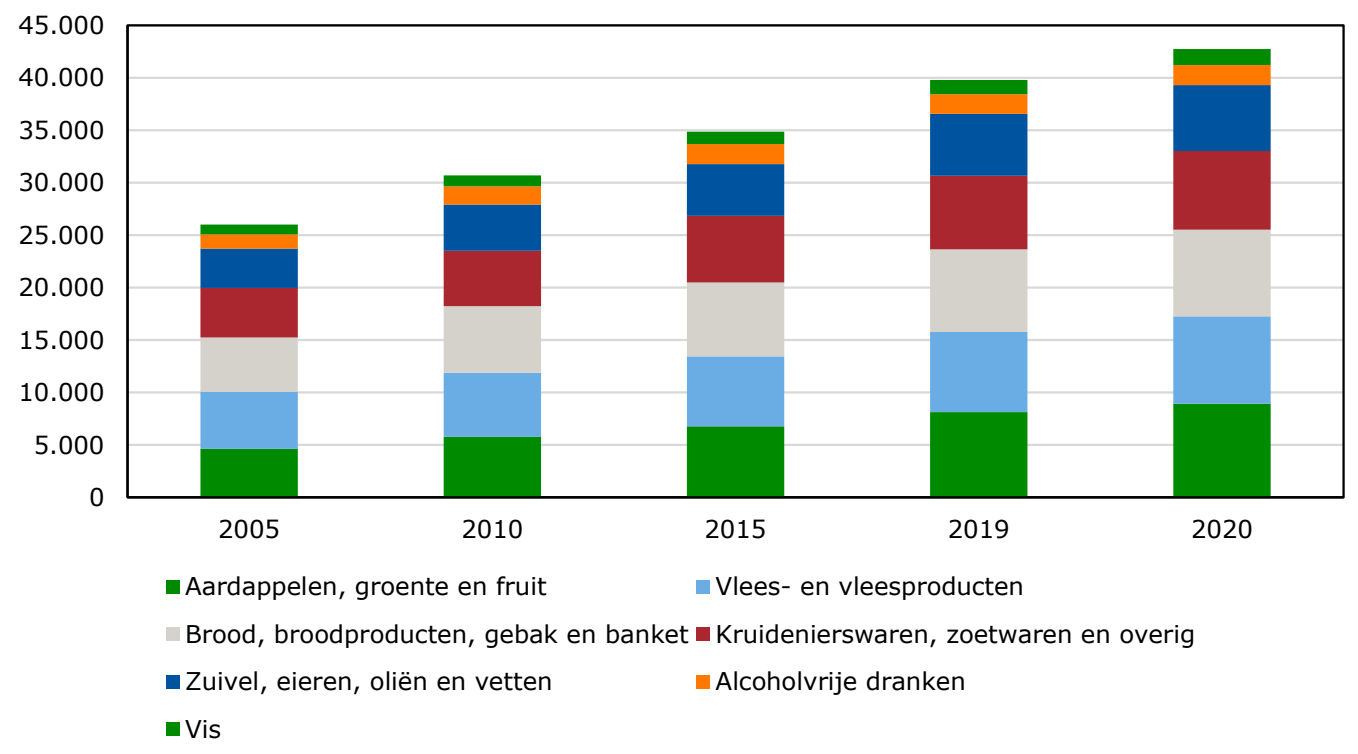

Figuur 3.4 Consumptieve bestedingen van huishoudens (mld. euro) aan voedingsmiddelen en alcoholvrije dranken

Bron: CBS Consumptieve bestedingen; verbruiksfunctie, nationale rekeningen. Berekening: Wageningen Economic Research.

\subsubsection{Uitgaven aan voedsel met duurzaamheidskeurmerk}

Voedingsmiddelen en dranken met een duurzaamheidskeurmerk winnen aan de populariteit bij consumenten. In 2020 was het aandeel van de uitgaven aan voedsel met een duurzaamheidskeurmerk met onafhankelijke controle (ASC, Biologisch, Beter Leven, Fair Trade/Max Havelaar, MSC, On the way to PlanetProof, Rainforest Alliance, UTZ Certified, Label Rouge en Vrije Uitloop) in de supermarkten, de foodservice en gespecialiseerde winkels in duurzamer voedsel (natuurwinkels, biologische supermarkten, etc.) $16 \%$ of circa 8,2 mld. euro (Logatcheva, 2021). Dit aandeel is in de loop der jaren gegroeid. In 2009 was dit aandeel nog 3\%, zie Figuur 3.5. De grootste uitgaven aan voedsel met een duurzaamheidskeurmerk vinden plaats in supermarkten, ruim 7 mld. euro in 2020. Het aandeel van de bestedingen aan voedsel met een duurzaamheidskeurmerk in supermarkten is tussen 2013 en 2020 gegroeid van $8 \%$ naar $19 \%$.

De groei van de bestedingen in 2020 is gedreven door de stijging in de afzet van voedsel met een duurzaamheidskeurmerk in supermarkten en gespecialiseerde biologische winkels. De afzet is toegenomen door het verschuiven van de vraag door Covid-19 gerelateerde beperkingen in de foodservice. Mede door deze verschuiving is in totaal $9 \%$ meer aan alle voedsel en dranken (met en zonder duurzaamheidskeurmerk) besteed in supermarkten en biologische winkels in 2020 ten opzichte van 2019. Daarnaast is er een extra groei in afzet van voedsel met een duurzaamheidskeurmerk in de supermarkten 
geweest. De uitgaven aan voedsel met een duurzaamheidskeurmerk in supermarkten zijn in dezelfde periode met $21 \%$ gestegen.

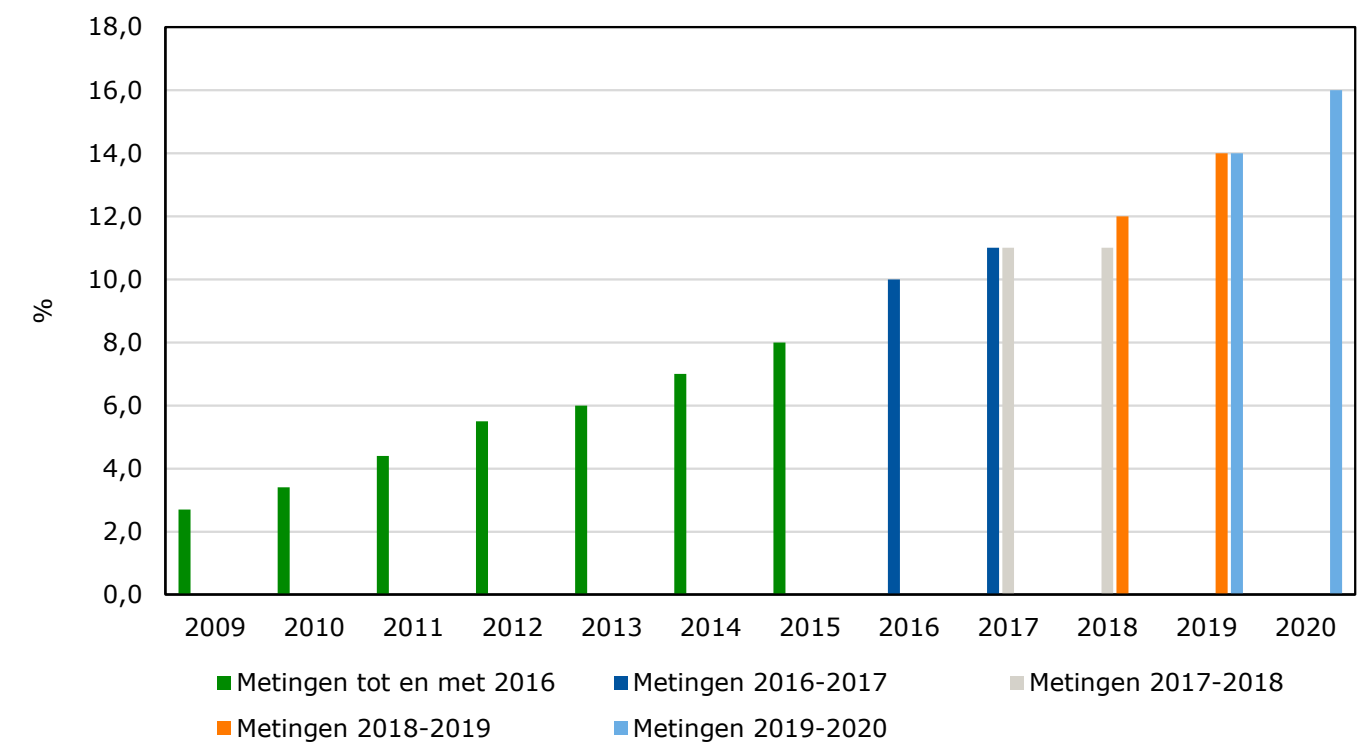

Figuur 3.5 Aandeel bestedingen voedsel met een duurzaamheidskeurmerk in supermarkten, de foodservice en biologische winkels (natuurwinkels, biologische supermarkten, etc.) in de totale voedselbestedingen. Metingen met gewijzigde methode zijn afzonderlijk weergegeven Bron: Logatcheva (2021) op basis van data Wageningen Economic Research/CBS, Foodstep, Bionext.

Er zijn verschillen tussen de productgroepen en jaren in hoe de bestedingen aan voedsel met een duurzaamheidskeurmerk zich ontwikkelen. Veranderende consumentenvoorkeuren en de beschikbaarheid van gecertificeerde grondstoffen zorgen voor dynamiek in vraag en aanbod van dit voedsel. De grotere sprongen hebben meestal te maken met het introduceren en uitrollen van een (nieuw) keurmerk voor een specifieke productgroep en de afspraken die retailers maken over het aanbieden van het integrale assortiment van een bepaalde productgroep onder een keurmerk. Voorbeelden zijn het aanbieden van alle vers varkensvlees minimaal onder 1 ster van Beter Leven, of alle huismerkkoffie, -thee en chocolade minimaal onder UTZ Certifieer of Rainforest Alliance.

In 2020 lieten de bestedingen aan bijna alle productgroepen met een duurzaamheidskeurmerk in de supermarkten, de foodservice en biologische winkels per saldo een groei zien. Een uitzondering is Koffie en thee, een productgroep waar traditioneel relatief veel aan wordt besteed in de foodservice. Stijgingen van bestedingen aan koffie en thee met een keurmerk in supermarkten en biologische winkels hebben het wegvallen van de afzet in de foodservice niet goed kunnen maken. 


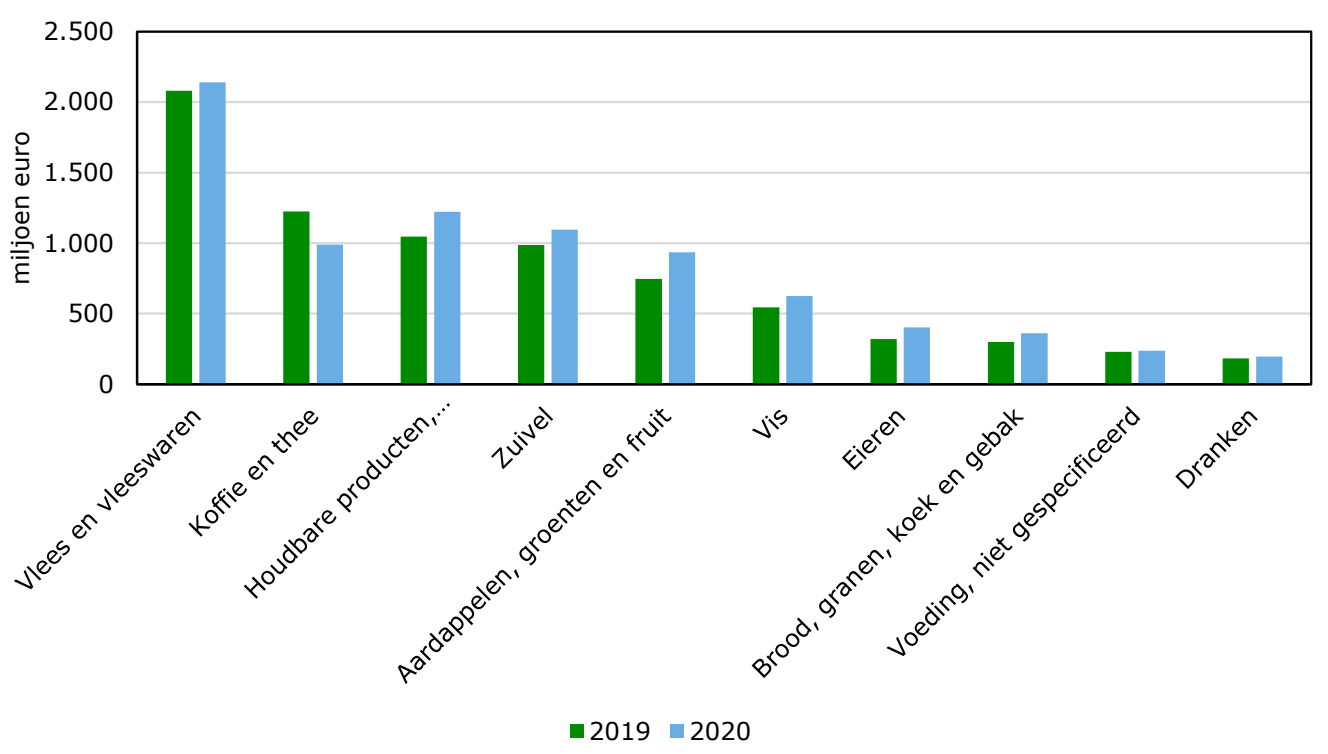

Figuur 3.6 Bestedingen aan voedsel met een duurzaamheidskeurmerk per productgroep in supermarkten, de foodservice en biologische winkels (natuurwinkels, biologische supermarkten, etc.)

Bron: Logatcheva (2021) op basis van data Wageningen Economic Research/CBS, Foodstep, Bionext.

\subsubsection{Omzet biologisch voedsel}

Binnen de bestedingen aan voedsel met een duurzaamheidskeurmerk heeft het Beter Leven keurmerk met $34 \%$ het grootste aandeel, gevolgd door Biologisch (18\%) en UTZ Certified (16\%). Het Europese keurmerk Biologisch is het enige keurmerk met uitgangspunten van de landbouw die in de EU-wetgeving zijn vastgelegd. Naar schatting wordt in Nederland 1,6 mld. euro aan voedselproducten met een biologisch keurmerk uitgegeven door consumenten. Het keurmerk heeft een lange periode in de lift gezeten. In de periode 2015-2019 zijn de bestedingen aan biologische producten in Nederland jaarlijks met 5\% tot $8 \%$ gestegen. In 2020 is de situatie voor biologisch anders door corona. De bestedingen aan biologisch voedsel zijn licht afgenomen met $1 \%$ door het wegvallen van de afzet in de foodservice. Stijgingen van de biologische afzet in supermarkten $(+9 \%)$ en biologische winkels $(+9 \%)$ hebben het verlies in de foodservice niet kunnen compenseren. Voor andere keurmerken met uitzondering van UTZ Certified (sterk in koffie en thee) is dit wel het geval geweest, zie Figuur 3.7.

Uit de recent uitgebrachte tweede Agro-Nutri Monitor door ACM blijkt dat de meeste consumenten in de praktijk niet bereid zijn een hogere prijs te betalen voor duurzame producten, terwijl het momenteel juist meer kost om biologische producten te maken dan gangbare alternatieven (Van Galen et al., 2021). De grootste belemmering voor de groei van de biologische sector zit dan ook in de geringe vraag van consumenten naar duurzame producten. 


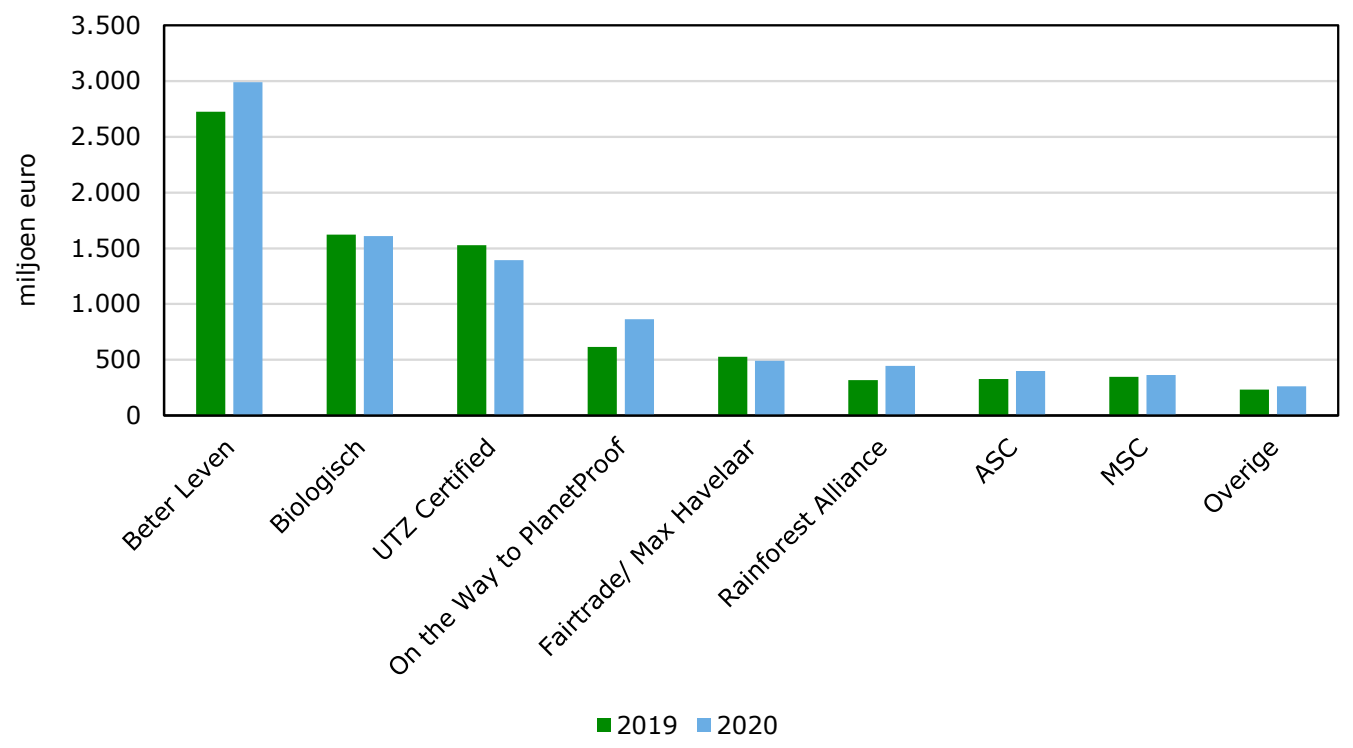

Figuur 3.7 Bestedingen aan voedsel per duurzaamheidskeurmerk in supermarkten, de foodservice en biologische winkels (natuurwinkels, biologische supermarkten, etc.)

Bron: Logatcheva (2021) op basis van data Wageningen Economic Research/CBS, Foodstep, Bionext.

\subsubsection{Voedselprijzen}

De voedselprijzenmonitor volgt de prijsontwikkelingen voor verschillende producten en voor verschillende schakels in de voedselketen. Iedere maand wordt de monitor cijfermatig bijgewerkt en om de maand inhoudelijk toegelicht. De grafieken die de prijsontwikkeling tonen zijn in de huidige vorm niet mee te nemen in deze pdf.

Voor de meest actuele stand van zaken wordt daarom verwezen naar agrimatie. ${ }^{25}$

\subsection{Voedselverspilling}

Voedselverliezen en voedselverspilling komen in de hele voedselketen voor. ${ }^{26}$ Voedselverspilling is de laatste jaren wereldwijd een punt van zorg geworden en het verminderen van verspilling staat steeds meer in de belangstelling. Voedselverspilling is gedefinieerd als al het voedsel, en niet-eetbare delen van voedsel, dat uit de voedselvoorzieningsketen wordt verwijderd om nuttig te worden toegepast of te worden verwijderd (met inbegrip van samengesteld, ondergeploegde/niet-geoogste gewassen, anaerobe vergisting, productie van bio-energie, warmtekrachtkoppeling, verbranding, afvoer naar riool, stortplaats of teruggooi in zee) (Fusion, 2014).

\section{EU-niveau}

Naar schatting wordt in de EU jaarlijks $88 \mathrm{mln}$. ton voedsel verspild, wat neerkomt op $173 \mathrm{~kg}$ verspild voedsel per persoon; de kosten die hiermee gepaard gaan, worden geraamd op ongeveer 143 mld. euro per jaar $^{27}$ (Fusions, 2016; Canali et al., 2017). Naast de hoge sociale en economische kosten draagt voedselverspilling bij aan klimaatverandering, met een geschatte bijdrage van $8 \%$ aan de broeikasgasemissies, en leidt het tot verspilling van schaarse hulpbronnen zoals land, energie en water.

\footnotetext{
25 https://www.agrimatie.nl/NieuwsDetail.aspx?subpubID=2424\&itemid $=7759$

${ }^{26}$ Op het niveau van de consument spreekt men ook wel van voedselverspilling, in de schakels daarvoor van voedselverliezen. De termen worden echter door elkaar gebruikt, in deze bijdrage hanteren we de term voedselverspilling.

27 De cijfers zijn voor 2012-2013 en met veel onzekerheid omgeven.
} 
De sectoren die het meest bijdragen aan voedselverspilling zijn huishoudens en voedselverwerking, samen goed voor $72 \%$; $28 \%$ van de voedselverspilling komt voor rekening van de food service en de primaire productie (tabel 3.4 ).

Tabel 3.4 Overzicht voedselverspilling naar sector, basis 2012-2013

\begin{tabular}{lccc}
\hline Sector & Verspilling in mIn. ton & Aandeel \\
\hline Huishoudens & 47 & 53 \\
\hline Voedselverwerking & 17 & 19 \\
\hline Foodservice & 11 & \\
\hline Primaire productie & 9 & 12 \\
\hline Groot- en detailhandel & 5 & 10 \\
\hline
\end{tabular}

Het feitelijke voedselverlies is slechts een deel van het probleem; alle factoren die hebben bijgedragen aan de productie van voedsel zijn ook verloren gegaan (land, water, menselijke \& (gemechaniseerde) arbeid, zaden, kunstmest, en alle andere investeringen in de oogst). Voedselverspilling leidt dus niet alleen tot voedselonzekerheid en financieel verlies voor de actoren in de voedselketen en de consumenten, maar ook tot een enorme verspilling van hulpbronnen.

Cijfers voedselverspilling voor NL

Volgens het Voedingscentrum lag de totale hoeveelheid afval in Nederland in de hele voedselketen in 2017 tussen de 1.814 en 2.509 kiloton (Voedingscentrum, 2021). Omgerekend per inwoner is dat tussen de 106 en 147 kilo per persoon, waarbij huishoudens zo'n 23 tot 32\% van het totale afval in de keten voor hun rekening nemen.

De jaarlijks verschijnende Monitor Voedselverspilling geeft in de meest recente versie aan dat de totale hoeveelheid voedselverspilling in Nederland tussen 2009 en 2018 niet is toegenomen, noch is afgenomen (Soethoudt en Vollebregt, 2020). De voedselverspilling bedroeg volgens de auteurs in 2018 per hoofd van de bevolking tussen de 96 en 149 kilogram. Daarbij tekenen ze aan dat een exact getal binnen deze bandbreedte niet is te geven, omdat gegevens over afvalstromen per ketenschakel vooralsnog incompleet zijn en vaak niet bekend is welk aandeel voedsel is in een afvalstroom. Voor de monitor wordt gebruik gemaakt van cijfers uit geaggregeerde landelijke statistieken, waardoor de oorsprong en herkomst van reststromen niet altijd te achterhalen zijn. De experts hebben daarom aannames gedaan over de minimale en maximale hoeveelheid voedsel per afvalstroom. Sinds 2018 zijn er verschillende stappen gezet om voedselverspilling tegen te gaan. Het is echter nog niet goed mogelijk om het effect hiervan in de cijfers terug te zien vanwege de hiervoor genoemde bandbreedte in de cijfers over voedselverspilling.

\section{Beleid van invloed op voedselverspilling}

Het beleid dat van invloed is op voedselverspilling, is tamelijk breed. Het varieert van voedselveiligheids- en hygiënebeleid (zoals donatie van voedsel, diervoeder), tot visserijbeleid (denk aan bijvangst), financieel beleid (belastingverlagingen) of energiebeleid (bijvoorbeeld stimulansen voor anaerobe vergisting/biogasinstallaties). Een evaluatie van Vittuari et al. (2015) heeft tweeënvijftig wetgevingshandelingen geïdentificeerd met implicaties voor voedselverspilling die onder EU-wetgeving en beleid vallen.

De meeste van deze gebieden kunnen een positief (in termen van vermindering of preventie) of een negatief (in termen van productie) effect op de voedselverspilling hebben, afhankelijk van de wijze waarop de wetgevings- en beleidsinstrumenten worden toegepast. Een werkdocument van de Europese Commissie concludeerde al in 2014 dat het EU-beleid de preventie van voedselverspilling nog niet op een actieve manier stimuleerde, en evenmin resultaten kon garanderen binnen een vast tijdskader in overeenstemming met de mijlpalen die de Commissie zelf en het Parlement hebben vastgesteld (EC, 2014).

In Nederland is in december 2018 het nieuwe initiatief 'Samen tegen Voedselverspilling' opgericht. Dit initiatief is geïnitieerd door de Taskforce Circulaire Economie in Voedsel, en bestaat uit bedrijven en publieke 
organisaties. De taskforce wil de voedselverspilling in Nederland in 2030 met de helft verminderen ten opzichte van het niveau in 2015. Daartoe zijn activiteiten en pilots geformuleerd voor vier verschillende actielijnen. Actielijn 1 gaat om het meten \& monitoren voedselverspilling, actielijn 2 stimuleert bedrijfsinnovatieve acties in de hele agrovoedingsketen, actielijn 3 is gericht op bewustmaking en specifieke interventies voor consumenten. Actielijn 4 ten slotte richt zich op het wijzigen van regelgeving, wetgeving en bedrijfsovereenkomsten om belemmeringen voor de preventie en vermindering van voedselverspilling weg te nemen.

Momenteel hebben 95 organisaties zich als lid aan het initiatief verbonden. Het ministerie van LNV stelt tussen 2018 en 2022 in totaal $7 \mathrm{mln}$. euro beschikbaar om de doelstelling te ondersteunen via investeringen in innovatie, onderzoek, monitoring en educatie.

\subsection{Dierenwelzijn in de markt - speciaal onderwerp}

In de loop van 2023 zal alle vers pluimveevlees in de supermarkt minimaal 1 ster Beter Leven keurmerk kennen. Een goed moment om terug te kijken op 12 jaar beleid dat deze marktontwikkeling ondersteunde. Wat valt op? Welke lessen zijn er uit te trekken?

Het Convenant Marktontwikkeling Verduurzaming Dierlijke Producten

Voorjaar 2009 sluit Minister Verburg van Landbouw, Natuur en Voedselkwaliteit het zogenaamde Marktontwikkeling Verduurzaming Dierlijke Producten convenant af, dat loopt tot en met 2011. De convenantpartijen zijn, naast LNV, de brancheorganisaties van (pluim)veehouders en van vleesverwerkers, het $\mathrm{CBL}$, Veneca, KNS en de Dierenbescherming. De doelstelling is een jaarlijkse omzetgroei van duurzame dierlijke producten met $15 \%$. De focus ligt op de ontwikkeling van de productie van eieren, pluimveevlees en varkensvlees met een duidelijke plus op dierenwelzijn en ondersteuning van het Beter Leven kenmerk van de Dierenbescherming dat in 2007 was gelanceerd. Daarmee staat de Stichting Milieukeur die ook een certificatie-schema ontwikkeld heeft voor duurzaam varkensvlees met milieu- en dierenwelzijnsaspecten, buiten het convenant.

Het Beter Leven kenmerk kent drie niveaus van dierenwelzijn (één, twee en drie sterren). Biologische productie heeft drie sterren per definitie. Het beheer van het kenmerk, zoals het vaststellen van normen, de groeistrategie, communicatiecampagnes en het gebruik van het beeldmerk ligt bij de Dierenbescherming (Monitor Duurzaam Voedsel, 2012). In de uitvoering sluit de Dierenbescherming met een ketenpartij (verwerker en verpakker) contracten af voor het gebruik van het kenmerk. Die partij maakt op zijn beurt afspraken met de toeleveranciers (veehouders). Later wordt deze uitvoering overgenomen door de Stichting Beter Leven kenmerk en zal het kenmerk een keurmerk worden.

Een van de inspirerende voorbeelden voor het convenant was ongetwijfeld het Volwaard scharrelkuiken; een kuiken van een langzamer groeiend ras dat de beschikking heeft over een overdekte buitenuitloop. Het Volwaard scharrelkuiken kwam in 2007 in het winkelschap en in 2008 krijgt het eerste product de 1 ster van het Beter Leven kenmerk.

De overheid ondersteunt met het convenant markpartijen bij haalbaarheidsstudies en marktverkenningen en staat ook de Dierenbescherming bij in de verdere ontwikkeling en promotie van het kenmerk. Het idee is dat er ruimte is voor een 'tussensegment', omdat de stap naar biologisch groot is. In de jaren ervoor was het verbeteren van dierenwelzijn door marktwerking onderwerp van verkennend onderzoek binnen het BOprogramma 414-1 'Naar een maatschappelijk geaccepteerde veehouderij' 2003-2006.

\section{Marktontwikkeling}

De convenantsdoelstelling van $15 \%$ omzetstijging wordt al binnen de convenantperiode ruimschoots gehaald, zo blijkt uit de Monitor Duurzaam Voedsel van 2010 tot en met 2012 (zie tabel 3.5). Supermarkt Albert Heijn levert een belangrijke bijdrage door in 2011 uitsluitend varkensvleesproducten van het huismerk met 1 ster Beter Leven kenmerk aan te gaan bieden. Wel is het aandeel 1 ster Beter Leven nog klein: bij aanvang van het convenant is het $0,2 \%$ van de totale voedselbestedingen, aan het eind $0,8 \%$. Ook is het aandeel bestedingen aan alle duurzame producten op het totaal aan voedselbestedingen nog maar $4 \%$ in 2011 . Die 
duurzame bestedingen bestaan uit alle producten met duurzaamheidskeurmerken, waaronder Milieukeur (24,3 mln. euro) en biologisch. De bestedingen aan biologisch voedsel zijn in dat jaar het grootst van de duurzame voedselbestedingen: $817,3 \mathrm{mln}$. euro (Monitor Duurzaam Voedsel 2012).

Tabel 3.5 Omzet Beter Leven ( $\mathrm{m} / \mathrm{n}$. euro) en groei ten opzichte van jaar ervoor in convenantperiode

\begin{tabular}{llll}
\hline $\mathbf{2 0 0 9}$ & $\mathbf{2 0 1 0}$ & $\mathbf{2 0 1 1}$ & $\mathbf{2 0 1 2}$ \\
\hline 68,1 & $142,8(110 \%)$ & $311,70(118 \%)$ & $458,3(47,0 \%)$ \\
\hline
\end{tabular}

Bron: Monitors Duurzaam Voedsel 2010 tot en met 2012.

Nog voor het einde van de convenantperiode, in 2011, maken CBL en de vleessectoren bekend te streven naar een betere standaard voor pluimvee- en varkensvlees. Het gaat dan niet om 1 ster Beter Leven, wel om een diervriendelijker productie dan gangbaar en met meer aandacht voor milieuaspecten, zoals veevoer van verantwoorde soja, minder broeikasgassen en uitstoot van fijnstof, en het gebruik van groene stroom. Het betekent de geboorte van de zogenaamde 'Vlees van Morgen' concepten.

Dat het in de aankondiging van CBL en vleessectoren om lagere eisen voor dierenwelzijn gaat dan bij 1 ster Beter Leven was te verwachten. Vooral voor pluimveehouders is de grote aanpassing voor 1 ster Beter Leven-productie groot, het gaat om het bouwen van een overdekte buitenuitloop die de nodige investeringen vraagt. Varkenshouders kunnen varkens binnen bestaande stallen meer ruimte geven voor 1 ster Beter Leven: $1 \mathrm{~m}^{2}$ per varken in plaats van de gangbare $0,8 \mathrm{~m}^{2}$. Al bij de ontwikkeling van de Volwaard-kip werd duidelijk dat lang niet alle vleeskuikenhouders animo hadden om te schakelen naar 1 ster Beter Leven. Ze zagen de differentiatie als een hindernis. Ook bleek de financiering naar 1 ster Beter Leven moeilijk en de afzet nog onzeker (Pluimveeweb, 2014). In de loop van 2013 en 2014 ontstaan zo verschillende concepten voor kippen- en varkensvlees bij de verschillende supermarkten.

In 2015 worden de dierenwelzijnseisen van Varken van Morgen aangepast aan Beter Leven 1 ster en eind van het jaar zal dat de minimumstandaard zijn bij alle supermarkten. De poging om tot één standaard te komen voor een Kip van Morgen strandt in 2015, omdat de ACM oordeelt dat de opzet concurrentiebeperkend is, te weinig op zou leveren voor verduurzaming en niet opweegt tegen de negatieve gevolgen, i.c. de hogere prijs voor de consument. De concurrentiebeperking betreft de onderlinge afspraak dat het reguliere product niet meer te koop zal zijn in de Nederlandse supermarkten (ACM, 2015). Uiteindelijk zijn in de loop 2017 alle supermarkten overgegaan op kippenvlees met Beter Leven 1 ster of varianten op de Kip van Morgen. Tot de laatste behoren bijvoorbeeld de Nieuwe Standaard Kip van Jumbo de Goed Nest Kip van Albert Heijn.

Anno 2020 is het aandeel in de omzet van voedsel met een duurzaamskeurmerk op het totaal $16 \%$. Dat is een groei van $12 \%$ punten ten opzichte van 2011. De omzet onder Beter Leven 1 ster voor eieren, varkensvlees, kalfsvlees en pluimveevlees is bijna $3 \mathrm{mld}$. euro (Monitor Duurzaam Voedsel 2021). Daarmee is het de omzet biologisch van 1,6 mld. euro voorbij gestreefd. Er is één varkenshouder met 2 sterren Beter Leven, maar bij eieren zijn er naast de biologische, verschillende concepten gekomen met 3 sterren Beter Leven. De supermarkt is het grootste afzetkanaal voor het Beter Leven keurmerk.

Naast producten met het Beter Leven keurmerk zijn andere certificerings-schema's ontstaan. Het certificerings-schema en label On the way to PlanetProof (als opvolger van Milieukeur) heeft een omzet van $865 \mathrm{mln}$. euro. Het kent eisen voor biodiversiteit, klimaat en dierenwelzijn. Het certificeringsschema is in 2017 geïntroduceerd voor plantaardige producten. Een aantal supermarkten eisen On the Way to PlanetProof voor producten zoals uien en tomaten. Eind 2018 is het schema ook geïntroduceerd in de melkveehouderij, als reactie op de introductie van Beter voor Koe Natuur en Boer door Albert Heijn. Dat label kent eisen voor onder andere weidegang, biodiversiteit en energie. On the Way to PlanetProof is een minimumeis voor de zuivelproducten voor de huismerken van een aantal andere supermarkten. FrieslandCampina voert het label op een aantal producten van het eigen merk. In 2019 heeft Jumbo melkveehouders gevraagd volgens de eisen van Beter Leven 1 ster te produceren (Agro-Nutri Monitor, 2021). 


\section{Lessen}

Deze 12 jaar beleidsontwikkeling voor dierenwelzijn laat zien dat er een beweging gemaakt is richting diervriendelijkere producten in de supermarkt, maar ook dat er bij zuivel een waaier aan certificeringsschema's is ontstaan voor dierenwelzijnsvriendelijkere en duurzamere productie. Wat zijn de lessen voor verduurzaming die via de markt moet lopen?

\section{De consument was geen drijvende kracht}

In het idee dat diervriendelijker productie door de markt te bereiken is, waarop het convenant gebaseerd was, spelen consumenten een belangrijke rol als aanjager van de vraag. In de praktijk is Beter Leven 1 ster (en andere certificeringsschema's) de minimale standaard geworden in de supermarkten bij varkensvlees en wordt het keurmerk het nog voor pluimveevlees. Met zo'n standaard valt er voor de consument binnen de supermarkt niet meer te kiezen voor het product zonder label. Het is misschien wel het meest praktisch, omdat de consument geroutineerd boodschappen doet en eigenlijk wil dat het met dierenwelzijn gewoon goed geregeld is (Ingenbleek et al., 2004). Aan deze onderkant van de markt lijkt de drijvende kracht richting diervriendelijker productie vooral de imago-schade van de supermarkt die niet meedoet met de nieuwe standaard. Aan de bovenkant van de markt laat de consument het zelf afweten. Immers, de consument kan kiezen voor biologische vleesproducten met 3 sterren, maar doet dat maar mondjesmaat. De biologische omzet blijft gering (Agro-Nutri monitor 2021). De vraag van de Nederlandse consument is maar beperkt aanjager geweest in de markt.

\section{Eerste stap: niet te hoog en niet te laag}

Varkensvlees is met Beter Leven 1 ster/Varken van Morgen als minimumstandaard in vijf jaar (na 2011) aanmerkelijk sneller gerealiseerd dan de Beter Leven 1 ster bij kippenvlees, want eind 2016 voldoet bijna alle varkensvlees in de supermarkt aan de eisen van 1 ster Beter Leven. Voor kippenvlees zal dat het geval zijn vanaf 2023, wat dan 12 jaar heeft gekost. Dat verschil in tempo is te verklaren, de meerkosten voor de pluimveehouders om van gangbaar naar 1 ster Beter Leven over te stappen waren aanzienlijk groter dan voor varkenshouders. Maar de aanpassingen voor 1 ster Beter Leven bij pluimvee tillen het dierenwelzijnsniveau voor pluimvee naar een niveau vergelijkbaar met Beter Leven 2 sterren of 3 sterren (Gocsik et al, 2016). Tussen de dierlijke sectoren zou er eigenlijk een vergelijkbaar instapniveau voor dierenwelzijn moeten zijn, niet te klein voor 'window dressing', maar ook niet zo groot als het daardoor voor marktpartijen financieel moeilijk wordt om in te stappen. Het risico voor de 'first movers' die het nieuwe concept als minimum standaard in het assortiment introduceren is dat ze consumenten zullen verliezen, omdat het prijsverschil met de concurrent groot zal zijn. Dit was in de pluimveesector de aanleiding om gezamenlijk over te willen stappen.

\section{Concurrentie met labels levert in-transparantie}

Er zijn voorlopig nog verschillende standaarden voor pluimveevlees, bij zuivel is er tussen de supermarkten en producenten concurrentie ontstaan op een aantal standaarden. Mogelijk voegt die concurrentie bij zuivel iets toe aan de klantwaarde of willen de partijen zich niet branden aan een oordeel van de ACM. Maar het leidt ook tot onvergelijkbaarheid van certificeringsschema's en brengt gebrek aan transparantie met zich mee, ondanks de keurmerkenwijzer van Milieu Centraal. Het zou beter zijn als de onderdelen waaruit de certificeringschema's zijn opgebouwd goed en op dezelfde manier gemeten worden, zodat de schema's onderling te vergelijken zijn. Als het niet voor de geroutineerde koper is, dan wel voor de geïnteresseerde burger en veehouders.

\section{Een onderliggend meetinstrument voor dierenwelzijn is technisch mogelijk}

Dierenwelzijn is lastig te meten, omdat het een multidimensionaal begrip is. Idealiter worden op basis van metingen aan het dier niet alleen zijn welzijn, maar ook de dierenwelzijnsprestaties van de individuele bedrijven en van een houderijsystemen gemeten ('outcome based'). Met behulp van die 'outcomes' zijn individuele bedrijven of labels met elkaar te vergelijken. Dit maakt ook classificatie (voor sterren) mogelijk op basis van de 'outcomes'. Dat te realiseren was precies het doel van het Welfare Quality-project dat in 2004 van start is gegaan. Naast de EU heeft ook de Nederlandse overheid fors geïnvesteerd in het project. In 2010 werd het afgerond met wetenschappelijk beproefde protocollen om dierenwelzijn te meten. Wetenschappelijke overeenstemming is één van de voorwaarden voor het gebruik van zo'n instrument (Ingenbleek et al., 2004). De protocollen bleken in de praktijk echter tijdrovend om toe te passen op het individuele veehouderijbedrijf. Er moest nog een praktische slag gemaakt worden om een vinger aan de pols te houden. 
ILVO, dat ook meewerkte in het Welfare Quality project, ontwikkelde in 2019 een app en zelfscan voor veehouders op basis van de protocollen. Zo'n soort instrument wordt nog niet gebruikt om de dierenwelzijnsresultaten van de labels in de markt te meten. Alhoewel wetenschappers het eens geworden zijn over hoe dierenwelzijn moet worden gemeten, en het mogelijk is een praktisch meetinstrument te ontwikkelen, staan verschillende eigenbelangen de invoering van zo'n instrument in de weg. De markt zal dit instrument niet brengen.

Publieke taak om meten te eisen

Als de markt zichzelf geen eenduidig meetinstrument oplegt dat dierenwelzijn 'outcomes' onderling vergelijkt en als transparantie nodig is om de markt voor verduurzaming te laten werken, dan wijst dit in de richting van een publieke taak om dat meten op te leggen of dat tenminste te eisen als duurzaamheidsclaims worden gedaan. Zo'n publieke taak gaat gepaard met kosten om het instrument te ontwikkelen en het 'up-to-date' te houden. Dat instrument hoeft echter niet slechts publiek betaald en uitgevoerd te worden; marktpartijen kunnen in de uitvoering en de financiering een rol spelen (Ingenbleek, 2006).

\section{Segmentering van de markt raakt de veehouders}

De verschillende eisen en certificeringsschema's hebben de markt gesegmenteerd. Als veehouders leveren aan een Nederlandse supermarkt, zijn er aanvullende eisen en vaak extra kosten. Veehouders ontvangen daarvoor in de regel een meerprijs. Maar delen uit de productie die op de buitenlandse markt moeten worden afgezet, hebben geen meerprijs (Agro-Nutri Monitor 2021). De zogenaamde vierkantsverwaarding is lastiger geworden. Bij zuivel zijn er daarnaast verschillende eisen per supermarkt of verwerker. Als de aanvullende eisen sterk verschillen en investeringen vergen, kan het veehouders in de weg staan om van afnemer te wisselen (Agri-Nutrimonitor 2021). Immers investeringen moeten worden terugverdiend. Segmentering kan de greep van afnemers op toeleveranciers versterken.

Ten slotte, omdat in een aantal EU-landen dezelfde ontwikkelingen in de markt plaatsvonden, is het tijd extra eisen en certificeringsschema's over de grenzen af te stemmen. Marktpartijen, NGO's, overheden en onderzoekers uit Noordwest-Europa werken op dit moment aan een onderliggend systeem om bestaande dierenwelzijnslabels te vergelijken en te ordenen (zie asapconference.eu). Dit zou onderlinge handel in dierlijke producten die voldoen aan bovenwettelijke eisen kunnen bevorderen. Wetgevers in de EU kunnen zich beraden of de onderkant die door de markt is opgetrokken een nieuw wettelijk minimum kan worden. 


\section{$4 \quad$ Land- en tuinbouw}

\subsection{Inleiding}

Dit hoofdstuk gaat dieper in op de structuurontwikkelingen in de land- en tuinbouw. Allereerst komen in paragraaf 4.2 de aantallen bedrijven, de inzet van de productiefactoren grond, arbeid en kapitaal, de veestapel, bedrijfsopvolging, duurzame investeringen en innovatie aan bod. De ruimtelijke verdeling van de landbouw komt in paragraaf 4.3 aan de orde. Paragraaf 4.4 schetst de ontwikkeling van de biologische landbouw. Paragraaf 4.5 gaat in op verbredingsactiviteiten en de ontwikkeling van korte ketens in de landbouw. De analyse van de inkomensontwikkelingen in de land- en tuinbouw, evenals een vergelijking van de inkomensontwikkeling voor de akkerbouw- en melkveehouderij in enkele andere EU-landen, komt in paragraaf 4.6 aan de orde. Met een beschouwing over de dilemma's bij de hervorming van het pachtstelsel sluit paragraaf 4.7 dit hoofdstuk af.

\subsection{Structuurontwikkelingen}

\subsubsection{Aantal bedrijven}

Het aantal land- en tuinbouwbedrijven is volgens de landbouwtelling in 2020 met ruim 500 afgenomen tot 52.700 , een daling met $1,0 \%$ (tabel 4.1 ). Dit is het vierde jaar op rij dat de vermindering van het aantal bedrijven ruim onder het langjarige gemiddelde blijft van bijna 3\% per jaar tussen 2000 en 2015.

Tabel 4.1 Land- en tuinbouwbedrijven naar bedrijfstype, 2000-2020

\begin{tabular}{|c|c|c|c|c|c|}
\hline & \multicolumn{4}{|c|}{ Aantal bedrijven } & \multirow{2}{*}{$\begin{array}{r}\text { Verschil (\%) } \\
2019-2020\end{array}$} \\
\hline & 2000 & 2010 & 2019 & 2020 & \\
\hline Glastuinbouw- en champignonbedrijven & 8.804 & 4.573 & 2.700 & 2.790 & 3,3 \\
\hline Opengrondstuinbouwbedrijven & 10.489 & 7.450 & 5.671 & 5.638 & $-0,6$ \\
\hline Akkerbouwbedrijven & 14.799 & 11.962 & 10.979 & 11.174 & 1,8 \\
\hline Melkveebedrijven & 23.280 & 17.519 & 14.923 & 14.542 & $-2,6$ \\
\hline Overige graasdierbedrijven & 20.208 & 19.073 & 10.083 & 10.117 & 0,3 \\
\hline Intensieve veehouderijbedrijven & 12.058 & 7.911 & 5.730 & 5.438 & $-5,1$ \\
\hline Gecombineerde bedrijven & 7.751 & 3.836 & 3.147 & 2.996 & $-4,8$ \\
\hline Land- en tuinbouwbedrijven, totaal & 97.389 & 72.324 & 53.233 & 52.695 & $-1,0$ \\
\hline
\end{tabular}

Bron: CBS, bewerking Wageningen Economic Research.

Veel minder vleesvarkensbedrijven

Het aantal intensieve veehouderijbedrijven is in 2020 met 5,1\% gedaald tot ruim 5.400 (tabel 4.1). Dat is meer dan de langjarige daling van gemiddeld 4\% per jaar. De afname in 2020 komt vrijwel geheel voor rekening van de vleesvarkensbedrijven, waarvan het aantal met $17 \%$ terugliep tot 1.240 bedrijven. Deze daling heeft onder meer te maken met het Actieplan Ammoniak Veehouderij. In het Actieplan Ammoniak Veehouderij is een landelijk gedoogbeleid opgenomen voor stoppende veehouderijen ('stoppersregeling') die niet voldoen aan de maximale emissiewaarden uit het Besluit emissiearme huisvesting. Veehouders die gebruik hebben gemaakt van de stoppersregeling van het actieplan moeten ofwel op 1 januari 2020 zijn gestopt met de varkens- of pluimveetak ofwel de huisvesting moet voldoen aan de eisen van het Besluit emissiearme huisvesting. Hoogstwaarschijnlijk hebben vooral kleinere bedrijven van de regeling gebruik gemaakt. De regeling heeft niet geleid tot een krimp van het aantal varkens, omdat de productierechten in omloop zijn gebleven. 
Subsidieregeling sanering varkensbedrijven (Srv)

In 2021 zal het aantal varkensbedrijven opnieuw versneld inkrimpen, nu door een opkoopregeling -

Subsidieregeling sanering varkenshouderijen (Srv) - om geuroverlast in veedichte gebieden

(concentratiegebieden Zuid en Oost) te verminderen. Hierbij komen de varkensrechten wel te vervallen. De overheid wil voorts de stikstofreductie die dit oplevert inzetten om woningbouw- en infrastructuurprojecten vlot te trekken. Voor de regeling zijn 502 aanvragen ingediend, waarvan 430 zijn goedgekeurd, en uiteindelijk 278 getekende overeenkomsten zijn ingediend (en 2 nog in behandeling; LNV, 2021a). Dat aantal komt overeen met $11 \%$ van de ruim 2.500 gespecialiseerde varkensbedrijven in 2020 , en met $8 \%$ van het aantal bedrijven met varkens in 2020. Het gaat om een mix van jongere en oudere bedrijven, kleinere en grotere. Dat hangt deels samen met de criteria, geuroverlast, en de vergoedingssystematiek. De subsidie bestaat uit een vergoeding voor het waardeverlies van de stallen van $197 \mathrm{mln}$. euro, en een marktconforme vergoeding voor de varkensrechten van $80 \mathrm{mln}$. euro. Van de begrote $450 \mathrm{mln}$. euro voor de Srv-regeling resteert een bedrag van ruim $170 \mathrm{mln}$. euro, waarvan een groot deel (133 mln. euro) gebruikt wordt voor de ophoging van het budget van de 1 e tranche van de regeling provinciale aankoop veehouderijlocaties (LNV, 2021a).

Nog twee opkoopregelingen veehouderijen

Om de stikstofuitstoot op overbelaste, stikstofgevoelige Natura 2000-gebieden te verminderen, zijn er twee maatregelen voor de vrijwillige opkoop van veehouderijen, de Maatregel Gerichte Opkoop (MGO) en de Landelijke beëindigingsregeling veehouderijlocaties (Lbv), waarvoor in totaal bijna 1,5 mld. euro is gereserveerd (LNV, 2021b).

De MGO is bedoeld voor de aankoop van veehouderijbedrijven met de grootste stikstofdepositie, de zogenaamde piekbelasters. De maatregel wordt in drie tranches door de provincies uitgevoerd met een budget van $483 \mathrm{mln}$. euro, waarvan $133 \mathrm{mln}$. is overgeheveld van de Subsidieregeling sanering varkenshouderijen. De eerste tranche van de MGO bestaat uit de 'Regeling provinciale aankoop veehouderijen nabij natuurgebieden' die begin november 2020 is opengesteld met een budget van ongeveer $230 \mathrm{mln}$. euro. De aankoopovereenkomsten moeten uiterlijk halverwege 2022 zijn afgesloten. De eerste tranche is een stoppersregeling, dat wil zeggen dat deelnemers niet elders een veehouderij mogen overnemen of starten, en dat de productierechten komen te vervallen. In de tweede tranche vervalt de stoppersverklaring ('beroepsverbod'), zodat bedrijfsverplaatsing mogelijk wordt, dat wil zeggen de overname van een bestaand bedrijf met dierrechten waarbij de emissie substantieel wordt verminderd.

De Landelijke beëindigingsregeling veehouderijlocaties (Lbv) beperkt zich tot de bedrijven met productierechten, de melkvee-, varkens- en pluimveebedrijven. Een van de deelnamevoorwaarden is dat de stikstofdepositie van de veehouderijlocatie op een overbelast, stikstofgevoelig Natura 2000-gebied een nog vast te stellen drempelwaarde overschrijdt. Bij het beëindigen van een bedrijf vervallen de productierechten. De Lbv wordt in twee tranches opengesteld, volgens de planning in 2022 met een budget van 720 mln. euro, en in 2025 met een budget van $250 \mathrm{mln}$. euro.

\section{Melkvee-, akkerbouw- en overige graasdierbedrijven}

Het aantal melkveebedrijven is in 2020 met bijna 400 afgenomen tot 14.500 , een daling van 2,6\%. Dat is veel minder dan de afname in de twee voorgaande jaren (bijna $9 \%$ in totaal), die vooral het gevolg was van de Subsidieregeling voor bedrijfsbeëindiging melkveehouderij. Dit was een van de maatregelen om de fosfaatproductie in de melkveesector omlaag te brengen, om zo onder het nationaal fosfaatplafond uit te komen voor het behoud van de derogatie.

Het aantal akkerbouwbedrijven is in de periode 2016-2020 licht gestegen, en het aantal overige graasdierbedrijven vrij constant gebleven. In 2016 is door de gewijzigde registratie van de land- en tuinbouwbedrijven ${ }^{28}$ een groot aantal (vooral kleine) graasdier- en akkerbouwbedrijven uit de landbouwtelling verdwenen. Dat het aantal bedrijven in deze sectoren ongeveer gelijk blijft, is waarschijnlijk mede het gevolg

\footnotetext{
${ }^{28}$ De belangrijkste wijziging is dat bedrijven die niet in het Handelsregister (Kamer van Koophandel) zijn opgenomen met een agrarische landbouwactiviteit, niet meer in de landbouwtelling zijn opgenomen. Tot 2015 hoefden onder meer landbouwers zich niet in te schrijven in het Handelsregister. Deze inschrijving is echter sinds 2015 als voorwaarde gesteld om in aanmerking te komen voor steun in het kader van het Gemeenschappelijk Landbouwbeleid. Het zijn in het algemeen bedrijven met een zeer kleine economische omvang die uit de registratie zijn weggevallen.
} 
van de instroom vanuit de melkveehouderij. Als bedrijven zonder melkveetak worden voortgezet, dan verandert de typering van melkveebedrijf meestal naar overig graasdier- of akkerbouwbedrijf.

\section{Opnieuw toename aantal glastuinbouwbedrijven}

Het aantal glastuinbouwbedrijven is volgens de landbouwtelling in 2020 opnieuw gestegen, met 90 (3,4\%) tot 2.670. Dat wijkt sterk af van de jaarlijkse afname vanaf de eeuwwisseling met 6 à $7 \%$. Het glasareaal nam in 2020 procentueel ongeveer evenveel toe als het aantal bedrijven, waardoor de gemiddelde oppervlakte glas per bedrijf vrijwel gelijk is gebleven. De toename van het aantal bedrijven heeft waarschijnlijk vooral te maken met een betere registratie van deze sector in de landbouwtelling.

Het aantal opengrondstuinbouwbedrijven is zowel in 2019 als in 2020 heel licht gedaald; over een langere periode (vanaf 2000) nam het aantal bedrijven met gemiddeld 3\% per jaar af.

\section{Aantal faillissementen blijft laag}

De afname van het aantal land- en tuinbouwbedrijven bestaat in hoofdzaak uit de min of meer vrijwillige bedrijfsbeëindiging bij generatiewisseling. Gedwongen beëindigingen in de vorm van faillissementen komen weinig voor. Na een periode (2009-2013) waarin relatief vrij veel land- en tuinbouwbedrijven failliet zijn verklaard, is het aantal faillissementen sterk afgenomen tot 14 in 2020 (figuur 4.1). Ook in 2021 blijft het aantal laag (10 tot en met september). Veruit de meeste faillissementen zijn uitgesproken in de plantaardige sectoren (85\% in de periode $2000-2020$ ) en dan met name in de (glas)tuinbouw.

Het verloop van het aantal faillissementen in de land- en tuinbouw tussen 2000-2019 lijkt sterk op dat voor alle bedrijven en hangt samen met de economische ontwikkeling. Zo kromp de Nederlandse economie in de periode 2009-2013 met gemiddeld 0,4\% per jaar, om daarna weer te groeien met gemiddeld 2,2\% per jaar in de jaren 2014-2019. Door de coronasteunmaatregelen is het aantal faillissementen in de gehele economie in 2020 laag, ondanks een krimp van het bbp met 3,8\%.

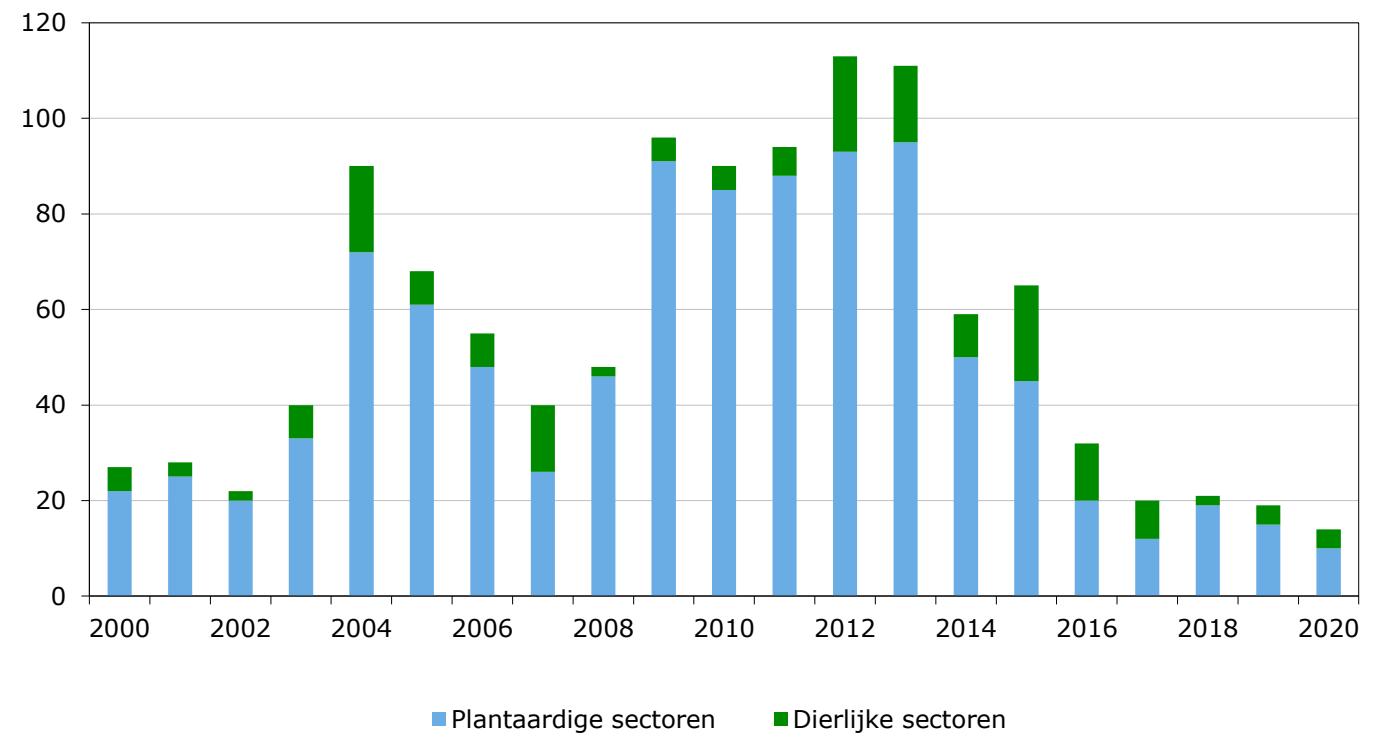

Figuur 4.1 Aantal faillissementen land- en tuinbouw, 2000-2020 Bron: CBS, bewerking Wageningen Economic Research.

\subsubsection{Grond}

Het areaal cultuurgrond in gebruik bij de geregistreerde land- en tuinbouwbedrijven is in 2020 uitgekomen op $1,814 \mathrm{mln}$. ha (tabel 4.2). Per saldo is het areaal cultuurgrond vanaf 2016 nauwelijks veranderd. Maar over een langere periode, tussen 2000 en 2020, is het areaal met gemiddeld 0,4\% per jaar verminderd. Van het totaal areaal cultuurgrond is nu $53,9 \%$ in gebruik als grasland (blijvend, tijdelijk en natuurlijk grasland), 
$11,4 \%$ voor groenvoedergewassen, $29,0 \%$ voor akkerbouwland, 5,1\% voor opengrondstuinbouw en $0,6 \%$ voor glastuinbouw.

Het aandeel rustgewassen in het bouwplan van de Nederlandse akkerbouwbedrijven is de afgelopen tien jaar met vijf procentpunten afgenomen tot $42 \%$. Het aandeel rustgewassen is het laagst in de IJsselmeerpolders, maar ook in andere akkerbouwgebieden staat het aandeel onder druk.

Tussen 2014 en 2020 is het totaal areaal eiwitrijke gewassen toegenomen met 3.900 ha tot 23.500 ha. De toename heeft mede te maken met de invoering van de vergroeningsmaatregelen in 2014, meer in het bijzonder het ecologisch aandachtsgebied (EA).

\section{Toelichting}

De basis voor de oppervlakte cultuurgrond is de Landbouwtelling. De oppervlakte agrarisch terrein volgens de CBS-statistiek bodemgebruik is veel groter dan het areaal cultuurgrond volgens de Landbouwtelling. Dit is het gevolg van onder meer verschillen in definities en afbakening. Zo is de definitie van agrarisch terrein ruimer en worden daar ook bijvoorbeeld erven en tuinen toe gerekend, cultuurgrond daarentegen is de oppervlakte waarop de gewassen staan. De afbakening van de Landbouwtelling is eveneens beperkter, aangezien niet alle gebruikers van landbouwgrond zijn opgenomen in de Landbouwtelling.

Het areaal cultuurgrond in gebruik bij de geregistreerde land- en tuinbouwbedrijven is in 2016 eenmalig sterk afgenomen door de wijzigingen in de registratie van de land- en tuinbouwbedrijven. Ten opzichte van 2015 daalde het areaal met circa 30.000 ha tot $1,82 \mathrm{mln}$. ha, een krimp van $1,6 \%$.

Tabel 4.2 Agrarisch grondgebruik, 2000-2020 a)

\begin{tabular}{|c|c|c|c|c|c|c|}
\hline & \multicolumn{5}{|c|}{ Areaal (1.000 ha) } & \multirow{2}{*}{$\begin{array}{r}\text { Verschil (\%) } \\
2019-2020\end{array}$} \\
\hline & 2000 & 2010 & 2018 & 2019 & 2020 & \\
\hline Grasland en voedergewassen & $1.249,5$ & $1.232,9$ & $1.203,1$ & $1.181,6$ & $1.184,4$ & 0,2 \\
\hline w.v. grasland & $1.036,7$ & 995,3 & 987,1 & 983,4 & 977,5 & $-0,6$ \\
\hline snijmais & 205,3 & 230,8 & 205,6 & 187,4 & 195,8 & 4,5 \\
\hline Akkerbouw & 634,4 & 542,1 & 516,0 & 531,9 & 526,8 & $-1,0$ \\
\hline w.v. granen & 225,7 & 218,8 & 167,6 & 179,8 & 173,6 & $-3,5$ \\
\hline aardappelen & 180,2 & 158,3 & 165,0 & 167,5 & 165,6 & $-1,1$ \\
\hline suikerbieten & 110,9 & 70,6 & 85,2 & 79,2 & 81,5 & 2,9 \\
\hline overig & 117,6 & 94,5 & 98,2 & 105,5 & 106,2 & 0,7 \\
\hline Tuinbouw open grond & 81,1 & 87,1 & 94,3 & 93,2 & 93,1 & 0,0 \\
\hline w.v. groenten & 22,4 & 24,5 & 26,1 & 25,6 & 26,0 & 1,5 \\
\hline fruit & 20,6 & 19,5 & 20,4 & 20,4 & 19,9 & $-2,2$ \\
\hline bloembollen & 22,5 & 23,3 & 27,6 & 27,2 & 27,0 & $-0,8$ \\
\hline boomkwekerij & 12,6 & 16,9 & 16,9 & 16,7 & 16,7 & 0,1 \\
\hline Tuinbouw onder glas & 10,5 & 10,3 & 9,0 & 9,7 & 10,1 & 4,0 \\
\hline w.v. groenten & 4,2 & 5,0 & 5,0 & 5,3 & 5,6 & 5,5 \\
\hline sierteelt & 5,9 & 4,8 & 3,5 & 3,8 & 3,9 & 2,9 \\
\hline Cultuurgrond, totaal & $1.975,5$ & $1.872,3$ & $1.822,4$ & $1.816,3$ & $1.814,5$ & $-0,1$ \\
\hline
\end{tabular}

a) Peildatum 15 mei.

Bron: CBS-landbouwtelling.

\section{Beperkte daling areaal grasland mede door derogatie}

De totale oppervlakte grasland is in 2020 heel licht $(0,6 \%)$ gedaald tot ruim 978.000 ha (tabel 4.2). Binnen het areaal grasland wordt onderscheid gemaakt in blijvend, natuurlijk en tijdelijk grasland. Blijvend grasland is grasland dat minimaal vijf jaar achtereen op hetzelfde perceel wordt geteeld, met een opbrengst van meer dan vijf ton droge stof per ha per jaar. Voor natuurlijk grasland geldt onder meer een opbrengst van minder dan vijf ton droge stof per ha per jaar. Tijdelijk grasland is grasland dat maximaal vier jaar achtereen op 
hetzelfde perceel wordt geteeld. In 2020 is het areaal blijvend grasland met 0,5\% gestegen tot 694.000 ha, het areaal natuurlijk grasland steeg met $2 \%$ tot 78.000 ha en het areaal tijdelijk grasland nam met $5 \%$ af tot 205.000 ha.

Sinds de invoering van de derogatie in 2006 - de mogelijkheid om meer stikstof per ha uit dierlijke mest te gebruiken - is het areaal grasland nauwelijks afgenomen: tussen 2005 en 2019 met 22.000 ha, ofwel 2,2\%. Een derogatiebedrijf moet minimaal $80 \%$ van het areaal landbouwgrond gebruiken als grasland (voor 2014 was dat $70 \%$ ). Deze eis in combinatie met de grote deelname aan de derogatie heeft waarschijnlijk bijgedragen aan de beperkte daling van het areaal grasland. In 2020 hebben zich 17.000 bedrijven aangemeld voor de derogatie, met een gezamenlijk landbouwareaal van 765.000 ha waarvan 668.000 ha grasland (87\%; LNV, 2021e). Dat is $68 \%$ van het totaal areaal grasland. De derogatie heeft als gevolg dat het areaal snijmais is afgenomen.

\section{Ruim voldoende blijvend grasland voor vergroeningseis}

Sinds 2015 zijn landbouwers verplicht vergroeningsmaatregelen uit te voeren om in aanmerking te komen voor de directe betalingen van het Gemeenschappelijk Landbouwbeleid (GLB). Een van de maatregelen is het in stand houden van blijvend grasland, ofwel grasland dat minimaal vijf jaar niet in de vruchtwisseling is opgenomen. Natuurlijk grasland (zie hiervoor) dat aan de vijfjareneis voldoet, valt ook onder de definitie van blijvend grasland van de vergroening. Als het aandeel blijvend grasland op het totaal landbouwareaal $5 \%$ of meer afneemt ten opzichte van de referentieratio moet Nederland een omzetverbod en herstelplicht invoeren. De referentieratio is het aandeel blijvend grasland op het totaal landbouwareaal in het referentiejaar (2012). De referentieratio bedraagt 40,97\%. Tussen 2015 en 2017 is het aandeel blijvend grasland met 1 à $2 \%$ gedaald ten opzichte van de referentie; daarna is het aandeel gestegen tot $41,91 \%$ in 2020 (RVO, 2021a). In alle jaren is dus ruimschoots voldaan aan de vergroeningseis voor het behoud van blijvend grasland. Deze eis geldt op nationaal niveau. In het 7e actieprogramma Nitraatrichtlijn is een vergelijkbare maatregel opgenomen, maar dan op bedrijfsniveau: graasdierbedrijven moeten in 2027 op minimaal $70 \%$ van het areaal een rustgewas telen (zie hierna), waarvan minstens de helft bestaat uit permanent grasland (LNV en IenW, 2021).

\section{Lichte afname areaal akkerbouw}

$\mathrm{Na}$ een behoorlijke uitbreiding van het akkerbouwareaal in 2019 (16.000 ha) is het areaal in 2020 licht afgenomen $(1 \%)$, met ongeveer 5.000 ha tot 527.000 ha (tabel 4.2). De daling van het areaal komt vooral voor rekening van de granen, waarvan het areaal met ruim 6.000 ha kromp tot iets onder de 174.000 ha. Daarmee komt het aandeel van granen in 2020 uit op 33\%. Het areaal aardappelen is met 2.000 ha afgenomen tot bijna 166.000 ha in 2020 , ofwel $31 \%$ van het akkerbouwareaal. Het areaal suikerbieten is in 2020 met 2.300 ha uitgebreid tot 81.500 ha (15\% van het totale akkerbouwareaal). Cosun heeft het toewijzingspercentage voor 2022 vastgesteld op 105\% (tegen 102\% in 2021). De hogere toewijzing hangt samen met de lagere suikervoorraden, een lagere suikerproductie in 2021 dan gepland en de gunstige marktontwikkeling (Cosun, 2021). Het areaal akkerbouwgroenten is gestaag toegenomen, van 46.000 ha in 2000 tot meer dan 64.000 ha in 2020 , wat neerkomt op een jaarlijkse groei van $1,7 \%$. De akkerbouwgroenten waren in 2020 goed voor $12 \%$ van het akkerbouwareaal.

\section{Areaal tuinbouw open grond gelijk}

Het areaal opengrondstuinbouw is in 2020 met 93.100 ha praktisch gelijk aan het voorgaande jaar. Over een langere periode is het areaal opengrondstuinbouw geleidelijk gegroeid (circa $1 \%$ per jaar). Het totaal areaal opengrondstuinbouw beslaat nu 5,1\% van het grondgebruik, tegen $4,1 \%$ in 2000 .

\section{Opnieuw toename tuinbouw onder glas}

Het glastuinbouwareaal is tussen 2011 en 2015 sterk gekrompen (ruim 1.000 ha) als gevolg van economisch slechte jaren voor deze sector. Na een stabilisatie van het glasareaal in 2017-2018 rond de 9.000 ha, is het areaal glas in 2019 en 2020 met respectievelijk 700 en 400 ha gestegen tot 10.100 ha (tabel 4.2). Voor een deel kan de groei van het areaal worden toegeschreven aan een sterke verbetering van de inkomens in de glastuinbouw na 2013. Zo lag het aantal verleende vergunningen voor nieuwbouw van kassen in de jaren 2016-2019 een factor 1,4 boven het gemiddelde in de periode 2012-2015. Het vergunde nieuwbouwareaal steeg van ongeveer 50 ha per jaar in 2012-2015 tot 150 ha in de jaren 2016-2019. Dit is echter maar een deel van de verklaring voor de sterke toename van het glasareaal in 2019/2020, omdat er ook kassen 
worden vervangen en afgebroken. Een andere factor is een betere registratie van deze sector in de Landbouwtelling.

Verder lezen

Op agrimatie staat een analyse van de ontwikkeling in het areaal rustgewassen en het areaal eiwitgewassen. ${ }^{29}$

Informatie over de gebruikstitels van grond (pachtvormen) en over de pachtnormen is te vinden via agrimatie. $^{30}$

\subsubsection{Arbeid}

Het arbeidsvolume in de land- en tuinbouw is in 2020 met $1 \%$ gestegen tot 157.700 arbeidsjaareenheden $^{31}$ (aje; figuur 4.2 en tabel 4.3), binnen de land- en tuinbouw gebruikt als een maat voor het aantal voltijdbanen. Met de toename van het arbeidsvolume in $2019(2 \%)$ is in twee jaar tijd het aantal aje met 4.300 toegenomen. De grotere werkgelegenheid binnen de glastuinbouw (6.700 aje), dankzij de groei van de sector in bedrijven en glasareaal, overtrof de krimp in de meeste andere sectoren. Vanaf de eeuwwisseling tot 2018 is het arbeidsvolume met gemiddeld $2 \%$ per jaar gedaald.

Het arbeidsvolume is een maat voor de werkgelegenheid, uitgedrukt in voltijdbanen. Hiervoor wordt binnen de land- en tuinbouw de term arbeidsjaareenheid (aje) gebruikt. Een arbeidskracht die 2.000 uur of meer werkt, wordt gezien als 1 aje. In dit kengetal is (een deel van de) flexibele arbeid opgenomen, het totaal aan flexibele arbeid is echter lastig vast te stellen omdat de inzet is beperkt tot piekperioden en er geen sprake is van jaarrondbanen.

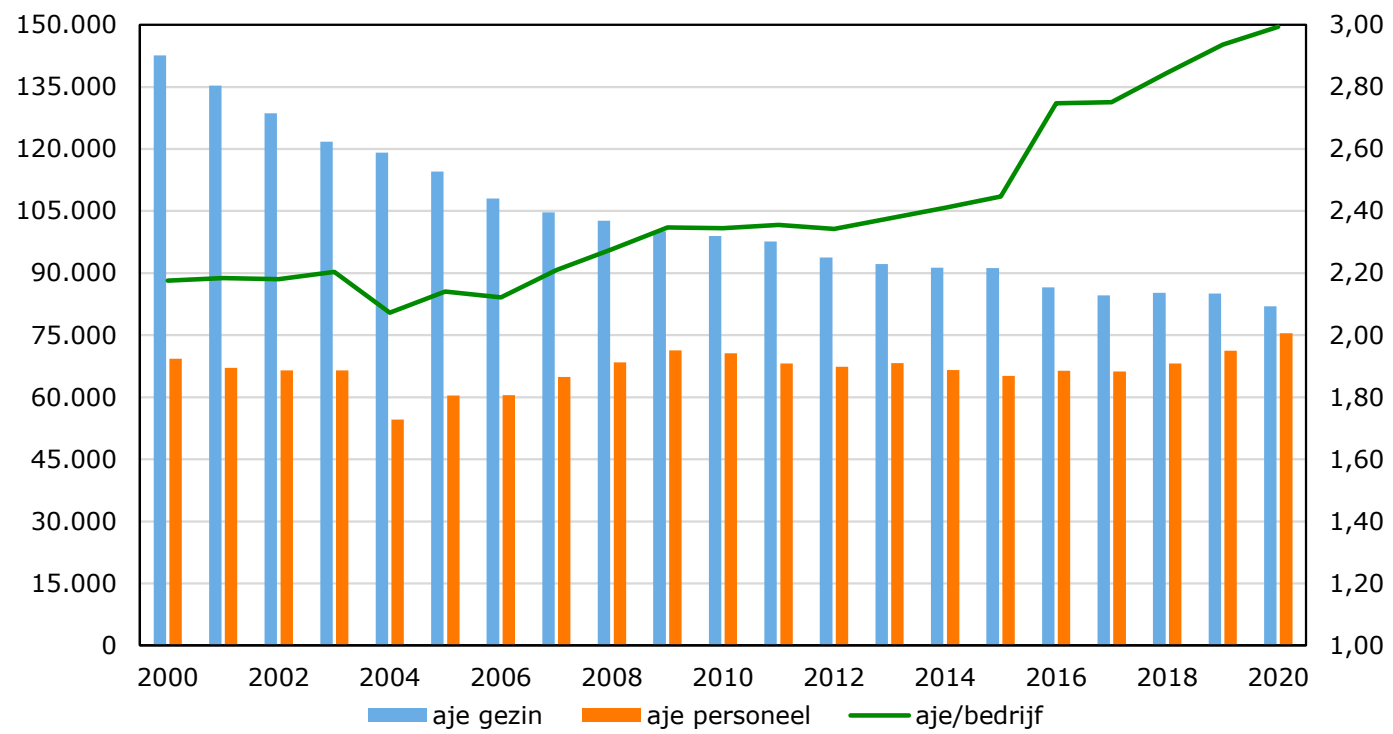

Figuur 4.2 Ontwikkeling arbeidsvolume land- en tuinbouw, 2000-2020

Bron: CBS-Landbouwtelling, bewerking Wageningen Economic Research.

De arbeidsinzet van het gezin is in 2020 met bijna 4\% gedaald tot 82.000 aje; van buiten het gezin nam de inzet met $6 \%$ toe tot 75.000 aje. Zo vindt een verdere verschuiving plaats van gezinsarbeid (tussen 2000 en 2020 van $66 \%$ naar $52 \%$, zie tabel 4.3 ) naar arbeid van buiten het gezin ( $48 \%$ in 2020 ). Dat geldt overigens alleen voor het volume van de niet-regelmatige arbeid, waarvan het aandeel op het totaal arbeidsvolume is

\footnotetext{
${ }^{29}$ https://www.agrimatie. nl/PublicatiePage.aspx?subpubID $=2525 \&$ sectorID $=3534$ \&themaID $=2286$

30 https://www.agrimatie. nl/PublicatiePage.aspx?subpubID $=2525 \&$ sectorID $=2243$ \&themaID $=3588$ \&indicatorID $=3523$

${ }^{31}$ Dit cijfer wijkt af van het cijfer in paragraaf 2.2.1 als gevolg van een verschil in de afbakening van de primaire sector, die in het agrocomplex ruimer is en het gebruik van verschillende bronnen.
} 
toegenomen van $7 \%$ in 2000 tot $21 \%$ in 2020 . Het aandeel van het arbeidsvolume van personeel met een vast contract is al die tijd vrij stabiel gebleven op ruim een kwart.

Meeste werkgelegenheid in glastuinbouw en melkveehouderij

Bijna de helft van de werkgelegenheid (op basis van het arbeidsvolume in aje) is geconcentreerd op de glastuinbouw- en melkveebedrijven (tabel 4.3). De samenstelling verschilt echter sterk: in de melkveehouderij heeft het gezin veruit de grootste inbreng ( $88 \%$ in 2020), terwijl dat in de glastuinbouw geldt voor vast en los personeel ( $89 \%$ in 2020). De vermindering van het aantal bedrijven in combinatie met een sterke schaalvergroting in de tuinbouw - vooral de glastuinbouw - heeft gezorgd voor een verschuiving van gezinsarbeid naar personeel van buiten het gezin. Van het personeel buiten het gezin werkt nu $77 \%$ op tuinbouwbedrijven (glastuinbouw- en opengrondstuinbouwbedrijven). De bedrijven in de meer grondgebonden sectoren steunen nog altijd voor het overgrote deel op de inzet van het gezin.

Tabel 4.3 Werkgelegenheid op land- en tuinbouwbedrijven naar bedrijfstype, 2000 en 2020

\begin{tabular}{|c|c|c|c|c|c|c|}
\hline \multirow[t]{2}{*}{ Bedrijfstype } & \multicolumn{2}{|c|}{ Aantal aje a) } & \multicolumn{2}{|c|}{ Aandeel (\%) gezin } & \multicolumn{2}{|c|}{ Aje per bedrijf } \\
\hline & 2000 & 2020 & 2000 & 2020 & 2000 & 2020 \\
\hline Glastuinbouw & 52.693 & 43.676 & 28 & 9 & 6,0 & 15,7 \\
\hline Opengrondstuinbouw & 33.988 & 27.759 & 47 & 32 & 3,2 & 4,9 \\
\hline Akkerbouw & 19.374 & 17.299 & 81 & 78 & 1,3 & 1,5 \\
\hline Melkvee & 45.810 & 33.527 & 93 & 88 & 2,0 & 2,3 \\
\hline Overige graasdier & 22.801 & 15.003 & 85 & 82 & 1,1 & 1,5 \\
\hline Intensieve veehouderij & 22.164 & 13.134 & 79 & 66 & 1,8 & 2,4 \\
\hline Gecombineerd & 15.298 & 7.326 & 85 & 70 & 2,0 & 2,4 \\
\hline Alle & 212.129 & 157.724 & 66 & 52 & 2,2 & 3,0 \\
\hline
\end{tabular}

a) Arbeidsjaareenheid.

Bron: CBS-Landbouwtelling, bewerking Wageningen Economic Research.

\section{Snellere toename arbeidsbezetting}

De benodigde arbeid per bedrijf neemt toe door de groei van de bedrijfsomvang en daalt door toename van de arbeidsproductiviteit. Het eerste effect is iets groter waardoor over een langere periode bezien de gemiddelde arbeidsbezetting per bedrijf is gestegen, van 2,18 aje in 2000 tot 2,99 aje per bedrijf in 2020 (figuur 4.2 en tabel 4.3), een gemiddelde jaarlijkse groei van 1,6\%. In 2016 vond een sprong plaats (van 2,45 naar 2,75 aje per bedrijf) door een verandering in de registratie van bedrijven, waardoor een groot aantal zeer kleine bedrijven met weinig arbeidskrachten wegviel. Tussen 2000 en 2015 nam de arbeidsbezetting toe met gemiddeld 0,8\% per jaar, en tussen 2016-2020 met 2,2\% per jaar.

Tussen de sectoren loopt de arbeidsbezetting in 2019 uiteen van 1,5 aje per bedrijf op de akkerbouw- en overige graasdierbedrijven, 2,3 aje op de melkveebedrijven, tot 15,7 aje per bedrijf op de glastuinbouwbedrijven. In de laatste sector is de arbeidsbezetting vanaf 2000 met een factor 2,6 gestegen.

\section{Aantal regelmatig werkzame arbeidskrachten}

Een andere wijze van berekening van de werkgelegenheid gaat uit van het aantal arbeidskrachten, waarbij niet wordt gekeken naar de inzet in arbeidsuren. Van de 175.000 regelmatig werkzame (vaste) arbeidskrachten volgens de Landbouwtelling behoren anno 2020 ruim 117.000 tot het gezin (bedrijfshoofden, echtgenoten en meewerkende familie), ofwel $67 \%$ tegen $71 \%$ in 2016 . Het aantal nietgezinsarbeidskrachten (verder ook aangeduid met personeel) is met 58.000 in 2020 gelijk aan het voorgaande jaar. In deze cijfers zijn de flexibele arbeidskrachten (uitzendkrachten en personeel met tijdelijke contracten) niet opgenomen. De vaste arbeidskrachten hebben meestal volledige jaarrondbanen, terwijl de inzet van flexibele arbeidskrachten met name in de tuinbouwsectoren beperkt is tot de piekperioden. In de oogst-/piekperioden kunnen grote aantallen mensen aan het werk zijn, maar slechts voor (hele) korte perioden. 
In piekperioden ruim tweemaal zoveel inhuur personeel

In het arbeidsmarktonderzoek van de sector agrarisch en groen (waaronder loonwerk en hoveniers) ook de omvang van de inhuur van arbeidskrachten opgenomen (van Hulle en Grotenhuis, 2020). In 2019 waren er in de primaire land- en tuinbouw 230.000 mensen werkzaam, waarvan 159.000 op de loonlijst stonden en 71.000 werden ingehuurd. Tijdens de piekperioden lag het aantal arbeidskrachten in 2019 op 329.000, waarvan 176.000 op de loonlijst en 153.000 op inhuurbasis (van Hulle en Grotenhuis, 2020). In de piekperioden zijn met andere woorden via inhuur ruim tweemaal zoveel mensen aan het werk in de land- en tuinbouw als buiten die perioden.

\section{Uitzendkrachten zijn vrijwel allemaal arbeidsmigranten}

Voor de personeelsvoorziening zijn de land- en tuinbouwbedrijven steeds afhankelijker geworden van arbeidsmigranten, werknemers zonder de Nederlands nationaliteit die werkzaam zijn bij Nederlandse bedrijven. In 2019 is ongeveer een derde van de werknemers in directe dienst bij de land- en tuinbouwsector een arbeidsmigrant, naar schatting 90\% van de uitzendkrachten is een arbeidsmigrant (Heyma et al., 2020).

\section{Aanbevelingen voor verbetering positie arbeidsmigranten}

De inzet van arbeidsmigranten kent verschillende problemen, zoals de soms sterke afhankelijkheid van de werkgever, veelal een uitzendbureau, die ook voor huisvesting en de zorgverzekering zorgt. Verlies van werk betekent dan vaak verlies van huisvesting en zorg. Andere knelpunten zijn onder meer onderbetaling en slechte huisvesting (kwaliteit, 'verkamering', overbewoning). Deze problemen zijn niet alleen nadelig voor de arbeidsmigranten zelf, maar ook voor werkgevers die wel goed omgaan met hun werknemers, en voor de leefbaarheid van wijken. Het Aanjaagteam Bescherming Arbeidsmigranten (2020) heeft deze bevindingen opgetekend in het advies Geen tweederangsburgers. Het aanjaagteam adviseert onder andere een verplichte certificering van uitzendbureaus, verbetering van de registratie van arbeidsmigranten (aanpassing Basisregistratie Personen), en verbetering van de huisvesting (zoals een verhuurdersvergunning en loskoppelen van het arbeids- en huurcontract).

\section{Ondanks corona geen hele grote problemen voor arbeidsvoorziening}

In het begin van de coronacrisis kwamen er minder arbeidskrachten uit het buitenland uit angst voor besmetting, maar was ook de vraag naar arbeid lager. Het tekort aan arbeidskrachten in de glasgroenteelt kon in de eerste weken van de crisis relatief snel worden ingevuld door personeel uit met name de sierteelt. In de maanden daarna is de instroom van buitenlandse arbeidsmigranten weer op gang gekomen (Berkhout en Bergevoet, 2020). De inzet van arbeid is uiteindelijk geen heel groot probleem geworden mede dankzij de flexibiliteit en initiatieven van de sector, zoals bemiddelingsplatforms voor arbeid, en steunmaatregelen van de overheid.

\section{Verder lezen}

Op agrimatie is meer informatie beschikbaar, onder andere over de toenemende spanning op de arbeidsmarkt in de landbouw. ${ }^{32}$

\subsubsection{Kapitaal}

De gemiddelde balanswaarde per einde boekjaar van de land- en tuinbouwbedrijven was in 2019 ruim 3,5 mln. euro; een stijging van 700.000 euro ten opzichte van 2015 (figuur 4.3). De toename is vooral te danken aan de hogere waarde van grond, lichte groei van de gemiddelde bedrijfsomvang en toegenomen waarde van immateriële activa door invoering van fosfaatrechten in 2018 in de melkveehouderij. Het aandeel van de grond op de balans bedraagt meer dan 50\%. De waarde van de immateriële activa, vooral dierrechten en fosfaatrechten, is in vijf jaar tijd gestegen van 60.000 euro naar 310.000 euro ( $9 \%$ van het balanstotaal). Al deze rechten zijn in Nederland onder voorwaarden verhandelbaar, de prijzen van deze rechten fluctueren op basis van aanbod en vraag. De waarde ervan wordt mede bepaald door beleidswijzigingen. De waarde en de samenstelling ervan verschillen sterk tussen bedrijven en bedrijfstypen. Het aandeel van de overige materiële activa, zoals machines en installaties en de woning, is de afgelopen

\footnotetext{
32 https://www.agrimatie.nl/PublicatiePage.aspx?subpubID =2525\&sectorID $=2243 \&$ themaID $=2264$ \&indicatorID $\% 20=\% 203589$
} 
5 jaar stabiel rond de 15\%. Op www.agrimatie.nl zijn van de balansen, zowel totaal land- en tuinbouw als per bedrijfstype, de tijdreeksen voor de periode 2001-2019 te raadplegen. ${ }^{33}$

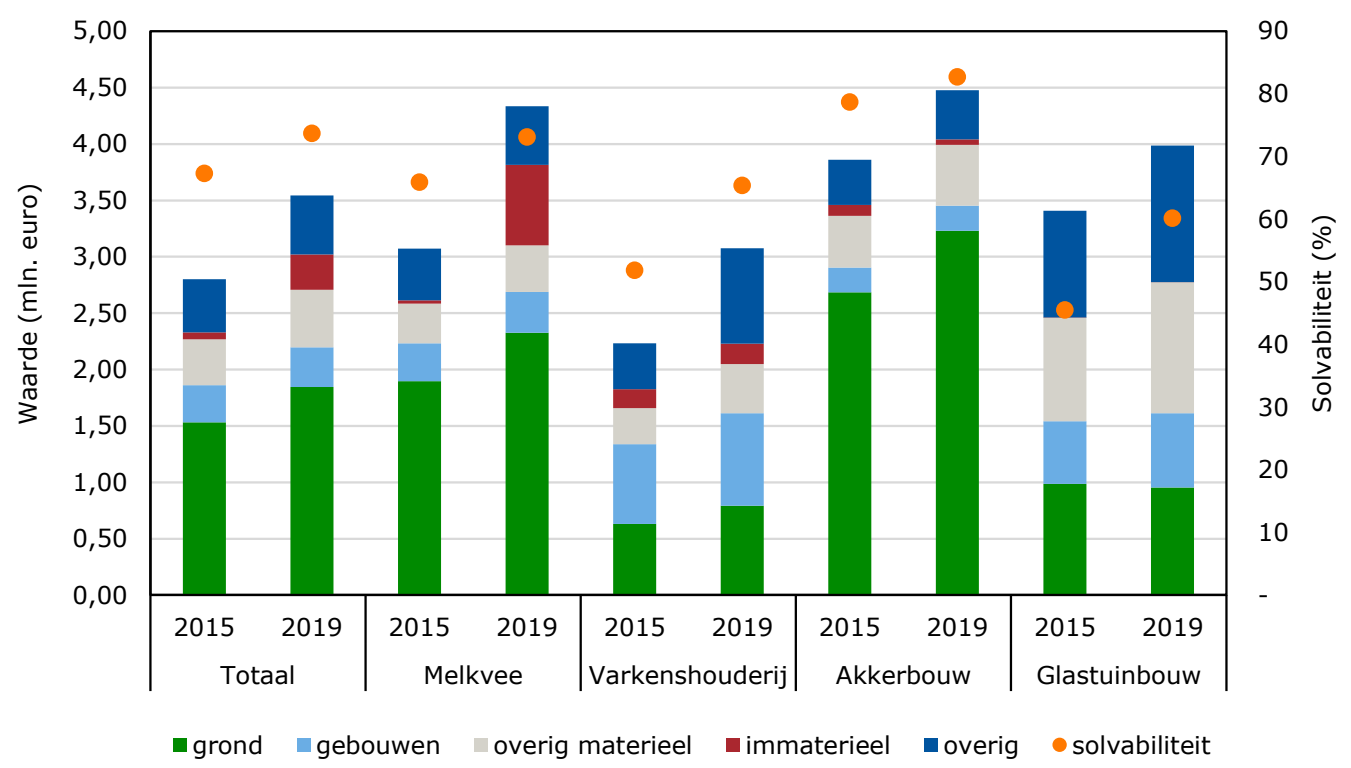

Figuur 4.3 Gemiddelde activa (in m/n. euro/bedrijf) en solvabiliteit (\%) land- en tuinbouwbedrijven naar type, 2015 en 2019 a)

a) Peildatum 31 december.

Bron: Bedrijveninformatienet.

\section{Ontwikkeling eigen vermogen}

In 2019 werd gemiddeld $74 \%$ van het balanstotaal van de Nederlandse land- en tuinbouwbedrijven gefinancierd met eigen vermogen; een toename van 7 procentpunten sinds 2015 (figuur 4.3). Hiermee is het eigen vermogen in de land- en tuinbouw, ruim 2,5 mln. euro in 2019, dus de belangrijkste financieringsbron. De grondgebonden bedrijven werken gemiddeld met een grotere inzet van eigen kapitaal dan de nietgrondgebonden bedrijven. De solvabiliteit is het hoogst op de akkerbouwbedrijven (83\% in 2019) en het laagst op de glastuinbouwbedrijven (60\%). Overigens is er ook een grote spreiding in solvabiliteit binnen de verschillende bedrijfstypen (zie beschikbare figuren op agrimatie. $\mathrm{nl}$ ). Vanuit het oogpunt van risicobeheer is het belangrijk dat bedrijven over een voldoende grote financiële buffer beschikken om inkomensfluctuaties op te vangen. Een lage solvabiliteit maakt bedrijven kwetsbaar voor dergelijke schommelingen. Het aandeel bedrijven met een solvabiliteit lager dan 35\% staat in 2019 op het laagste niveau sinds jaren, namelijk 4\%. Die bedrijven hebben in het algemeen te maken met relatief hoge betalingsverplichtingen aan rente en aflossing (agrimatie.nl).

\section{Herwaardering grond belangrijk voor ontwikkeling eigen vermogen}

De jaarlijkse vorming van eigen vermogen op land- en tuinbouwbedrijven vindt enerzijds plaats door herwaardering van aanwezige activa en anderzijds door liquide mutaties afkomstig uit besparingen, ontvangen erfenissen en overige vermogensmutaties.

Op de akkerbouwbedrijven droegen in de periodes 2010-2014 en 2015-2019 met name herwaardering (jaarlijks gemiddeld meer dan $4 \%$ ) en in mindere mate mutaties van liquide middelen door wisselende bedrijfsresultaten bij aan een toename van het eigen vermogen (figuur 4.4).Vooral de herwaardering van grond heeft daaraan bijgedragen.

\footnotetext{
${ }^{33}$ Zie van der Meulen et al. (2020) (figuur 3.4) voor de ontwikkeling en spreiding in balanstotaal voor diverse bedrijfstypen, 20012018.
} 


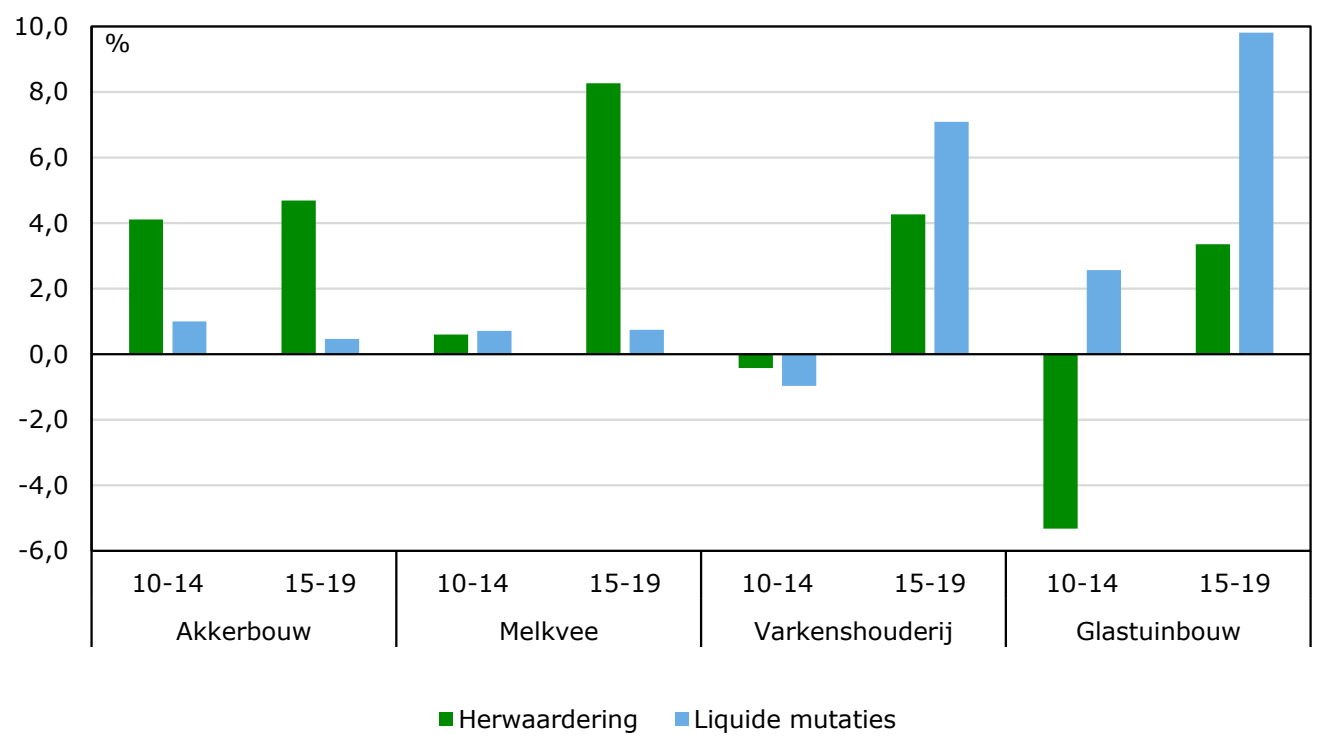

Figuur 4.4 Verloop eigen vermogen (in \% beginbalans) land- en tuinbouwbedrijven naar type, 2010-2019 Bron: Bedrijveninformatienet.

De toename van het eigen vermogen in de melkveehouderij in de periode 2010-2014 was beperkt met 1,3\% per jaar. Hieraan droegen herwaardering en bedrijfsresultaten voor een gelijk deel aan bij (figuur 4.4). In de meest recente jaren (2015-2019) zorgde de herwaardering van de activa voor een toename van het eigen vermogen. Dat is vooral te danken aan de invoering van de fosfaatrechten in 2018.

In de varkenshouderij is het eigen vermogen in het gepresenteerde tijdvak 2010-2014 verminderd door zowel negatieve herwaardering van productierechten als door slechte bedrijfsresultaten (liquide mutaties). De periode 2015-2019 is gemiddeld beter verlopen voor de varkenshouderij. Het eigen vermogen kon worden versterkt door een aantal jaren (2016, 2017 en 2019) met zeer goede bedrijfsresultaten en in mindere mate ook door herwaardering van aanwezige activa. Dit beeld komt ook terug in de toename van de solvabiliteit in die periode van $52 \%$ naar $65 \%$ (figuur 4.3 ).

De ontwikkeling van het eigen vermogen in de glastuinbouw laat voor de twee tijdvakken in de periode 2010-2019 een tegenovergesteld beeld zien. In het tijdvak 2010-2014 is het eigen vermogen vanuit de herwaardering gemiddeld gedaald door waardedaling van de grond. De grondprijzen stonden onder druk, omdat de vraag naar grond zowel binnen (nieuwbouw van kassen) als buiten (bouwkavels voor huizen) de tuinbouw af nam (agrimatie. $\mathrm{nl}$ ). De periode 2015-2019 laat een sterke verbetering van het eigen vermogen zien door met name een toename uit de liquide mutaties door de zeer goede bedrijfsresultaten (zie ook onderdeel inkomensontwikkeling) van jaarlijks gemiddeld 10\%. Daarnaast droeg herwaardering van de activa, met name gebouwen en grond, bij aan een toename van het eigen vermogen. De solvabiliteit verbeterde met 15 procentpunten naar $60 \%$ in 2019.

\section{Vreemd vermogen}

De gemiddelde financiering met vreemd vermogen per einde 2019 bedraagt iets minder dan $1 \mathrm{mln}$. euro. Hiervan heeft circa 800.000 euro betrekking op langlopende schulden. Overige bedrag bestaat uit kortlopende schulden en voorzieningen. Sinds 2007 is het aandeel van bancaire leningen in de langlopende schulden $90 \%$. Sinds 2010 vlakt de toename het gemiddelde bedrag aan bancaire leningen wel af (van der Meulen et al., 2020). De gemiddelde financieringslasten (rente- en provisiekosten) bedragen in 2019 circa 20.500 euro per bedrijf. Als gevolg van de gedaalde rentetarieven daalt dit bedrag sinds 2014; toen was het gemiddeld 30.000 euro per bedrijf.

Het totaal uitstaande bedrag aan langlopende financiering in de land- en tuinbouw is in de periode 20152019 gedaald van 38,7 mld. euro naar 36,1 mld. euro (figuur 4.5). Deze afname komt door een lager bedrag aan uitstaande leningen vanuit banken (34,8 versus 32,2 mld. euro in 2019) en komt voornamelijk op conto van de glastuinbouw. De langetermijnontwikkeling van het uitstaande bedrag aan bancaire leningen toont 
een toename van $18 \mathrm{mld}$. euro in 2002 tot circa $35 \mathrm{mld}$. euro in 2011 met stabilisatie tot 2015 en daarna een lichte daling (van der Meulen et al., 2020). Dit heeft mede te maken met de strengere regels rondom financiering (Basel-akkoorden). Familieleningen en overige leningen zijn over een langere periode redelijk constant met respectievelijk 2,7 mld. euro en 1,2 mld. euro in 2019 (zie ook figuur 4.5).

Binnen de land- en tuinbouw staat het grootste bedrag aan langlopende leningen uit in de melkveehouderij, ruim 15 mld. euro (figuur 4.5). ${ }^{34}$ Familieleningen komen met name voor op de grondgebonden bedrijfstypen akkerbouw en melkvee en spelen vaak een rol bij de financiering van de bedrijfsovername. In de glastuinbouw hebben de goede bedrijfsresultaten van de laatste jaren ruimte geboden om af te lossen op bancaire leningen. Het uitstaande bedrag bij banken nam in de periode 2015-2019 met 33\% af tot 2,6 mld. euro.

Bankleningen zijn op de balansen van de land- en tuinbouwbedrijven verreweg de belangrijkste bron van lang vreemd vermogen. Maar in de financiering op sectorniveau is het vermogen via de verschillende pachtvormen, het verpachtersvermogen, nu de belangrijkste bron van vreemd vermogen. Het verpachtersvermogen is de waarde van de grond en gebouwen die door verpachters aan de land- en tuinbouw ter beschikking is gesteld. Bij de raming van de waarde ervan is uitgegaan van de vrije verkoopwaarde van grond exclusief de waarde van de gepachte gebouwen (die te verwaarlozen is ten opzichte van de waarde van de grond). De waarde van de gepachte grond is opgelopen van 30 mld. euro in 2001 tot 51 mld. euro in 2019 (Silvis en Voskuilen, 2021).

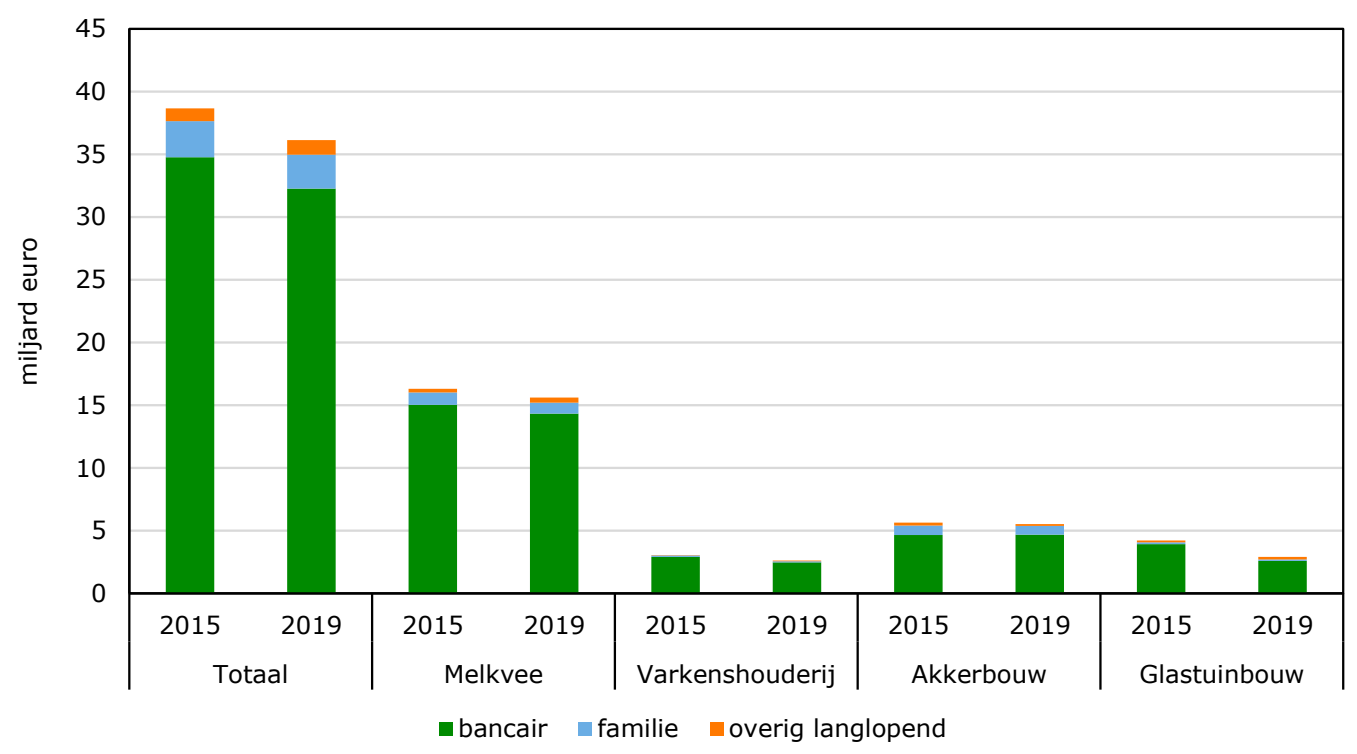

Figuur 4.5 Totaal vermogen aan langlopende financiering (in mld. euro) totale land- en tuinbouw en per type, 2015 en 2019

Bron: Bedrijveninformatienet.

\section{Toekomstige financieringsbronnen}

Banken zijn de laatste jaren kritischer bij kredietverlening dan in het verleden. Dit heeft onder meer te maken met Basel III-richtlijnen waaraan banken moeten voldoen. Vanaf 2023 hebben banken te maken met Basel IV-richtlijnen. Kern van deze nieuwe regelgeving rondom kapitaaleisen is dat banken gestuurd zullen worden om ondernemers nog meer te financieren op basis van rentabiliteit en liquiditeit in plaats van op de waarde (en daarmee onderpand) van activa als grond, gebouwen en installaties. Juist de rentabiliteit en liquiditeitspositie van agrarische ondernemers zijn volatiel. Toch zullen ook in de toekomst banken in duurzame agrofinanciering de belangrijkste speler zijn. Een reden hiervoor is dat land- en tuinbouwbedrijven over het algemeen een laag rendement op eigen vermogen, gemiddeld zo'n 3 à 4\%, realiseren. Hierdoor zijn

\footnotetext{
34 Zie van der Meulen et al. (2020) (figuur 3.12) voor de ontwikkeling van het totaal vermogen aan langlopende leningen voor diverse bedrijfstypen, 2001-2018.
} 
andere partijen dan banken minder geïnteresseerd in het verstrekken van krediet. De overheid speelt een rol in de financiering door garant/borg te staan op bancaire leningen verstrekt via de regeling Borgstelling MKBlandbouwkredieten (BL). In 2020 heeft het fonds de volgende faciliteiten: Borgstellingskrediet voor de landbouw (BL); Borgstellingskrediet voor de landbouw Plus (BL Plus); Landbouwinnovatie; en het Vermogensversterkend Krediet (VVK). Vanaf 2001 werd in de meeste jaren meer dan $40 \mathrm{mln}$. euro met garanties verleend met een piek van bijna $140 \mathrm{mln}$. euro in 2004 (Van der Meulen et al., 2020).

\subsubsection{Veestapel}

Melkveestapel redelijk stabiel

Het aantal melkkoeien is in 2020 heel licht gestegen, met $1 \%$ tot 1,59 mln. In de periode 2000-2007 daalde het aantal dieren (tot 1,41 mln.), waarna door verruiming van het melkquotum in de periode 2005-2014, overschrijding van het melkquotum in de jaren voor het afschaffen van de quotering en het einde daarvan per 1 april 2015, het aantal melkkoeien steeg tot 1,74 mln. in 2016. Door de fosfaatmaatregelen is het aantal melkkoeien in de daaropvolgende drie jaar met $10 \%$ gedaald tot $1,58 \mathrm{mln}$. in 2019. De maatregelen bestonden uit het fosfaatreductieplan 2017 en de invoering van fosfaatrechten per 1 januari 2018. Met de invoering van de fosfaatrechten is evenals in de varkens- en pluimveehouderij, nu ook in de melkveehouderij de veestapel begrensd door productierechten (tabel 4.4).

\section{Jongveebezetting afgenomen}

De jongveestapel voor de melkveeproductie - die ook meetelt voor de fosfaatrechten - is sterker ingekrompen dan het aantal melkkoeien, met $30 \%$ tot $0,94 \mathrm{mln}$. stuks. Hierdoor is verhouding tussen het aantal stuks jongvee en melkkoeien afgenomen: van gemiddeld ruim 80 voor 2017, tot 59 stuks jongvee per 100 melkkoeien in 2020. Tot aan de invoering van de fosfaatrechten hielden melkveehouders relatief ruim jongvee aan, dit gaf de ruimte om op latere leeftijd te selecteren. Daarnaast fungeerde de ruime jongveestapel als een soort van veiligheidsbuffer bij extra problemen of uitval. Economisch gezien was dit niet optimaal en de invoering van de fosfaatrechten is de prikkel geweest om minder jongvee aan te houden, zodat er meer ruimte blijft voor melkkoeien.

Tabel 4.4 Ontwikkeling veestapel (aantal dieren, 1.000 stuks), 2000-2020 a)

\begin{tabular}{|c|c|c|c|c|c|c|}
\hline & 2000 & 2010 & 2018 & 2019 & 2020 & $\begin{array}{r}\text { Verschil (\%) } \\
2019-2020\end{array}$ \\
\hline Rundvee, totaal & 4.069 & 3.975 & 3.919 & 3.810 & 3.838 & 0,7 \\
\hline w.v. melkkoeien & 1.504 & 1.479 & 1.622 & 1.578 & 1.593 & 1,0 \\
\hline jongvee melkproductie & 1.325 & 1.239 & 1.032 & 924 & 935 & 1,2 \\
\hline vlees- en weidevee & 457 & 330 & 248 & 243 & 239 & $-1,9$ \\
\hline vleeskalveren & 783 & 928 & 1.017 & 1.066 & 1.071 & 0,5 \\
\hline Overige graasdieren & 1.601 & 1.625 & 1.541 & 1.620 & 1.613 & $-0,4$ \\
\hline w.v. schapen & 1.305 & 1.130 & 866 & 918 & 890 & $-3,0$ \\
\hline geiten & 179 & 353 & 588 & 615 & 633 & 2,9 \\
\hline paarden en pony's & 117 & 143 & 88 & 88 & 90 & 3,2 \\
\hline Varkens, totaal & 13.118 & 12.255 & 12.430 & 12.269 & 11.950 & $-2,6$ \\
\hline w.v. fokzeugen & 1.129 & 984 & 923 & 889 & 871 & $-2,1$ \\
\hline biggen & 5.102 & 5.124 & 5.653 & 5.549 & 5.414 & $-2,4$ \\
\hline vleesvarkens & 6.505 & 5.904 & 5.631 & 5.618 & 5.446 & $-3,1$ \\
\hline Kippen, totaal & 104.015 & 101.248 & 105.104 & 101.741 & 101.863 & 0,1 \\
\hline w.v. leghennen & 32.573 & 35.310 & 35.427 & 33.403 & 31.999 & $-4,2$ \\
\hline vleeskuikens & 50.937 & 44.748 & 48.971 & 48.684 & 49.229 & 1,1 \\
\hline
\end{tabular}

a) Peildatum 1 april.

Bron: CBS-Landbouwtelling. 
Door corona minder vleeskalveren opgezet en geslacht

De vrij sterke uitbreiding van het aantal vleeskalveren in 2018 en 2019 kan naast uitbreiding op bestaande bedrijven, het gevolg zijn van instroom vanuit de melkveehouderij. Dat wil zeggen, melkveehouders die gestopt zijn met de melkveetak en gestart zijn met het houden van vleeskalveren. Het aantal gespecialiseerde vleeskalverenbedrijven is in deze twee jaar met een kleine 100 toegenomen tot bijna 1.300 (op een totaal aantal bedrijven met vleeskalveren van 1.680, het totaal aantal bedrijven met vleeskalveren is met 110 toegenomen).

Het aantal vleeskalveren is in 2020 nauwelijks veranderd, Het gaat hierbij om het aantal dieren op peildatum 1 april, zodat het effect van corona nog niet zichtbaar is. Voorts is dit aantal een overschatting, omdat het aantal (met ingang van 2018) wordt bijgesteld voor tijdelijke leegstand op basis van de opgave van het voorgaande jaar. Het aantal opgezette en geslachte dieren geeft meer inzicht in de mogelijke gevolgen van corona. Het aantal geslachte dieren is gedaald van 1,65 mln. in 2019 tot 1,56 mln. in 2020 (CBS), een afname van ruim 5\%. Dit komt overeen met de daling van het aantal opgezette vleeskalveren in 2020 volgens de Stichting Kwaliteitsgarantie Vleeskalversector (SKV, 2021). Ongeveer de helft van de opgezette kalveren wordt geïmporteerd. In 2010 was $36 \%$ van de importkalveren nog afkomstig uit Oost-Europa (inclusief Letland, Estland en Litouwen), tegen 6\% in 2020. Dit is vooral het gevolg van de enorme afname van de import uit Polen, onder meer door uitbraken van ziektes en de ontwikkeling van de stierhouderij in Polen (zie ook paragraaf 2.3.9). De meeste geïmporteerde dieren komen nu uit Duitsland, België en Luxemburg; over de afgelopen vijf jaar ging het gemiddeld om ruim $80 \%$, waarvan het merendeel (90\%) uit Duitsland.

\section{Onderzoek naar gezondheidsrisico's geitenhouderij vertraagd}

De geitenstapel is in 2020 verder toegenomen, met bijna 3\% tot 633.000 stuks. Daarmee zet de bijna onafgebroken groei zich voort, van circa 10.000 geiten in 1984 tot het huidige aantal. De groei is voor het laatst onderbroken tussen 2009 en 2010 door de uitbraak van Q-koorts en de daaropvolgende ruimingen van geiten. Naast schaalvergroting (meer dieren per bedrijf) zou de uitbreiding in de afgelopen jaren kunnen komen van melkveehouders die door de ingrepen in de melkveesector zijn omgeschakeld.

Omdat de risico's voor de volksgezondheid rond veehouderijen niet duidelijk zijn, hebben de meeste provincies beperkingen aan de geitenhouderij opgelegd (zie kader). Voor eventuele aanpassingen van het beleid wordt vooral uitgekeken naar de resultaten van het onderzoeksprogramma Veehouderij en Gezondheid Omwonenden (VGO) III. Door de coronacrisis is het onderzoek vertraagd; verwacht wordt dat het gehele VGO-III-onderzoek eind 2024 zal zijn afgerond (LNV, 2021c).

\section{Acht provincies met bepalingen over houden van geiten}

In zeven provincies - Overijssel, Gelderland, Utrecht, Noord-Holland, Zuid-Holland, Noord-Brabant en Limburg - is een volledige 'geitenstop' opgenomen in de omgevingsverordening, dat wil zeggen een verbod op nieuwvestiging en uitbreiding van, en omschakeling naar geitenhouderij. In Flevoland is de geitenstop niet volledig: bestaande geitenhouderijen op meer dan twee kilometer van de rand van een woonkern mogen uitbreiden (ruimtelijke plannen.nl; lokaleregelgeving.overheid.nl).

\section{Vier provincies zonder expliciete bepalingen over geitenhouderij}

In de vier provincies zonder expliciete bepalingen in de omgevingsverordening over het houden van geiten, zijn er meestal wel beperkingen voor deze sector. Dat kan niet alleen via de verordening, ook gemeenten kunnen beperkingen opleggen aan de geitenhouderij.

In de Drentse verordening is een verbod opgenomen op nieuwvestiging van intensieve veehouderij, en op omschakeling van grondgebonden naar intensieve veehouderij. Geitenhouderijen vallen in de Drentse verordening onder intensieve veehouderij. Uitbreiding van bestaande geitenhouderijen en omschakeling binnen de intensieve veehouderij naar geiten zou dan in principe mogelijk kunnen zijn. De Zeeuwse verordening kent een vergelijkbare bepaling over de intensieve veehouderij, maar laat nog (theoretisch) ruimte voor grondgebonden geitenhouderij. In de omgevingsverordening van Groningen is opgenomen dat nieuwvestiging en uitbreiding van intensieve veehouderij niet is toegestaan, maar de geitenhouderij valt niet onder de begripsomschrijving van intensieve veehouderij in de Groningse verordening. In de verordening van Friesland zijn geen expliciete verboden opgenomen voor nieuwvestiging of uitbreiding van de intensieve veehouderij. In deze verordening wordt voor het begrip intensieve veehouderij het synoniem niet-grondgebonden veehouderij gebruikt, waaronder de niet-grondgebonden geitenhouderij (ruimtelijke plannen.nl; lokaleregelgeving.overheid.nl). 


\section{Minder varkens}

Na een lichte daling van het totaal aantal varkens in $2019(1,3 \%)$ is het aantal in 2020 opnieuw afgenomen, met $2,6 \%$ tot iets onder de $12 \mathrm{mln}$. (tabel 4.4). In twee jaar tijd is de varkensstapel met $0,5 \mathrm{mln}$. dieren gekrompen. De vermindering is onder meer het gevolg van het vervallen van rechten als onderdeel van de provinciale ruimte voor ruimte regelingen. Het effect van de Subsidieregeling sanering varkenshouderijen (Srv) is in deze cijfers nog niet zichtbaar, omdat de eerste varkensrechten binnen deze regeling vanaf november 2020 vervallen, en de gegevens in tabel 4.4 als peildatum 1 april 2020 hebben.

Al eerder zijn er saneringsregelingen geweest: de twee opkoopregelingen om het mestoverschot te verminderen (Regeling beëindiging veehouderijtakken) leidden in de periode 2001-2004 tot een inkrimping van de varkensstapel met zo'n twee mln. dieren tot $11 \mathrm{mln}$. Daarna trad een herstel op tot $12,6 \mathrm{mln}$. dieren in 2016; een groei die is begrensd door de varkensrechten (tabel 4.5). De komende jaren zal de varkenshouderij verder krimpen door verschillende saneringsregelingen. Naast de Srv-regeling zijn er twee nieuwe (vrijwillige) opkoopregelingen bijgekomen waarbij ook varkensrechten worden ingenomen, de Maatregel Gerichte Opkoop (MGO) en de Landelijke beëindigingsregeling veehouderijlocaties (Lbv) (zie bijdrage over aantal bedrijven).

\section{Subsidieregeling sanering varkenshouderijen (Srv): 7\% minder varkensrechten} Voor de Subsidieregeling sanering varkenshouderijen (Srv), waaraan alleen varkenshouders uit de concentratiegebieden Zuid en Oost konden meedoen, zijn 502 aanvragen ingediend. Daarvan zijn er 430 goedgekeurd, en zijn uiteindelijk 278 overeenkomsten ingediend (LNV, 2021d; zie bijdrage over aantal bedrijven). De deelnemers beschikken over circa 580.000 varkensrechten die komen te vervallen, ofwel bijna $7 \%$ van het totaal aantal varkensrechten in Nederland in 2019 (tabel 4.5). Voor het concentratiegebied Zuid gaat het om ongeveer 507.000 rechten (10\% van het totaal aantal rechten in dit gebied), en voor concentratiegebied Oost om 73.000 rechten ( $3 \%$ van het aantal rechten).

\section{Pluimveestapel gelijk}

Het totaal aantal kippen is in 2020 met 102 mln. vrijwel gelijk aan het voorgaande jaar (tabel 4.4). Ook in de pluimveesector is het aantal dieren begrensd in de vorm van pluimveerechten (tabel 4.5).

Het aantal vleeskuikens ligt vanaf 2015 vrij constant rond de $49 \mathrm{mln}$., ook in 2020 op de peildatum 1 april. Het aantal geslachte dieren in heel 2020 is wel gedaald, met 4,4\% ten opzichte van 2019 (CBS, voor 2020 voorlopige cijfers). Voor de toekomstige ontwikkeling van het aantal vleeskuikens zijn onder meer de opkoopregelingen en de aanscherping van de houderijsystemen door de supermarkten van belang. Vanaf 2023 stapt het merendeel van de Nederlandse supermarkten over op het Beter Leven keurmerk met 1 ster. Dat betekent een lagere stalbezetting dan in de reguliere houderij en de huidige supermarktconcepten, en het inrichten van een overdekte uitloop.

Het aantal legkippen is in twee jaar tijd met bijna $10 \%$ gedaald tot $32 \mathrm{mln}$. in 2020 , de afname van het aantal bedrijven bleef beperkt tot $3 \%$

\section{Productierechten begrenzen omvang veestapel}

De productierechten voor varkens, pluimvee (kippen en kalkoenen) en melkvee (fosfaatrechten) zijn bedoeld om de productie van dierlijke mest te begrenzen. De varkens- en pluimveerechten vervangen een deel van de mestproductierechten en zijn ingesteld op respectievelijk 1 september 1998 en 1 januari 2001. De fosfaatrechten voor het melkvee gelden per 1 januari 2018. De rechten zijn vrij verhandelbaar, maar voor de varkens- en pluimrechten gelden wel een aantal beperkingen: alleen overdraagbaar binnen concentratiegebied Zuid, binnen concentratiegebied Oost, buiten de concentratiegebieden en van de concentratiegebieden (Zuid en Oost) naar het niet-concentratiegebied.

Het totaal aantal varkensrechten is tussen 2018 en 2020 met 1,3\% gedaald, met een wat grotere afname in het concentratiegebied Zuid (1,9\%) (tabel 4.5). De vermindering is onder meer het gevolg van het vervallen van rechten als onderdeel van de ruimte voor ruimte regelingen van de verschillende provincies, en de Subsidieregeling sanering varkenshouderijen (Srv). Vanaf november 2020 zijn de eerste varkensrechten binnen de Srv-regeling geschrapt (LNV, 2021e). 
Tabel 4.5 Productierechten (1.000) in de veehouderij, 2018-2019

\begin{tabular}{lrrr}
\hline & $\mathbf{2 0 1 8}$ & $\mathbf{2 0 1 9}$ & $\mathbf{2 0 2 0}$ \\
\hline Varkensrechten totaal & 8.697 & 8.683 & 8.586 \\
\hline w.v. Concentratiegebied Zuid & 4.900 & 4.889 & 2.806 \\
\hline Concentratiegebied Oost & 2.283 & 2.256 & 1.509 \\
\hline Overig & 1.513 & 67.162 & 87.524 \\
\hline Pluimveerechten & 67.162 & 87.161 \\
\hline Fosfaatrechten melkvee & 85.713 & 85.567 \\
\hline
\end{tabular}

Bron: LNV (2021).

\section{Fosfaatbank blijft nog gesloten}

In 2018 zijn in totaal 85,7 mln. fosfaatrechten toegekend aan melkvee (tabel 4.5), iets boven het plafond voor melkvee van $84,9 \mathrm{mln}$. fosfaatrechten. Dat heeft te maken met afhandeling van bezwaren, toekenning fosfaatrechten voor knelgevallen en herbeoordeling jongvee (LNV, 2020). Om het aantal rechten onder het plafond te brengen en de 'fosfaatbank' te kunnen vullen, wordt bij de overdracht van fosfaatrechten een deel afgeroomd (met uitzonderingen); halverwege juni 2019 is het afromingsdeel tijdelijk verhoogd van $10 \%$ naar $20 \%$ totdat het aantal fosfaatrechten onder het fosfaatplafond is gekomen. Het percentage van 20 geldt tot op heden. Vanaf begin 2021 worden de afgeroomde rechten niet langer meer geschrapt, maar geplaatst in de fosfaatbank die nog wel gesloten blijft (LNV, 2021f). De rechten in de fosfaatbank zijn bedoeld voor het stimuleren van jonge melkveehouders, die grondgebonden produceren.

\section{Handel in fosfaatrechten}

De fosfaatrechten zijn vrij verhandelbaar waarbij een deel (nu 20\%) wordt afgeroomd, met uitzondering van overdrachten bij erfopvolging, bloed- of aanverwantschap in de 1e, 2e of 3 e graad, en vorming van een man-vrouwmaatschap, man-vrouwvennootschap onder firma en commanditaire man-vrouwvennootschap (RVO.nl).

Het aantal verhandelde fosfaatrechten met afroming is gedaald van 4,2 mln. in 2018 naar 2,4 mln. in 2019, en $2,6 \mathrm{mln}$. in 2020. Het aantal in 2019 is een schatting uitgaande van een gemiddelde afroming van $15 \%$. Afgezet tegen het totaal aantal toegekende rechten is de handel (met afroming) afgenomen van circa $5 \%$ in 2018 tot $3 \%$ in 2020 . Uitgedrukt in melkkoeien met een fosfaatproductie van 43,5 kg en na afroming komt dat ruwweg neer op bijna 90.000 en 50.000 dieren. Het verhoogde afromingspercentage zal aan de afgenomen handel hebben bijgedragen.

\subsubsection{Bedrijfsopvolging}

Het aantal land- en tuinbouwbedrijven met een bedrijfshoofd ouder dan 50 jaar is tussen 2012 en 2020 met tien procentpunten gestegen tot $71 \%$. Het gaat hierbij om de bedrijven met als rechtsvorm een natuurlijk persoon (zie kader). Bij deze op het oog sterke vergrijzing past wel een nuancering, omdat inmiddels het merendeel $(63 \%)$ van de natuurlijke personen bestaat uit samenwerkingsvormen in de vorm van maatschappen en vennootschappen onder firma. Bij samenwerking tussen de oudere en jongere generatie zijn er dus meer bedrijfshoofden, waarvan het jongere bedrijfshoofd over het algemeen jonger dan 50 jaar zal zijn. ${ }^{35}$

\footnotetext{
${ }^{35}$ In de landbouwtelling moet bij gelijke verantwoordelijkheid de oudste 'maat' als bedrijfshoofd worden aangemerkt.
} 


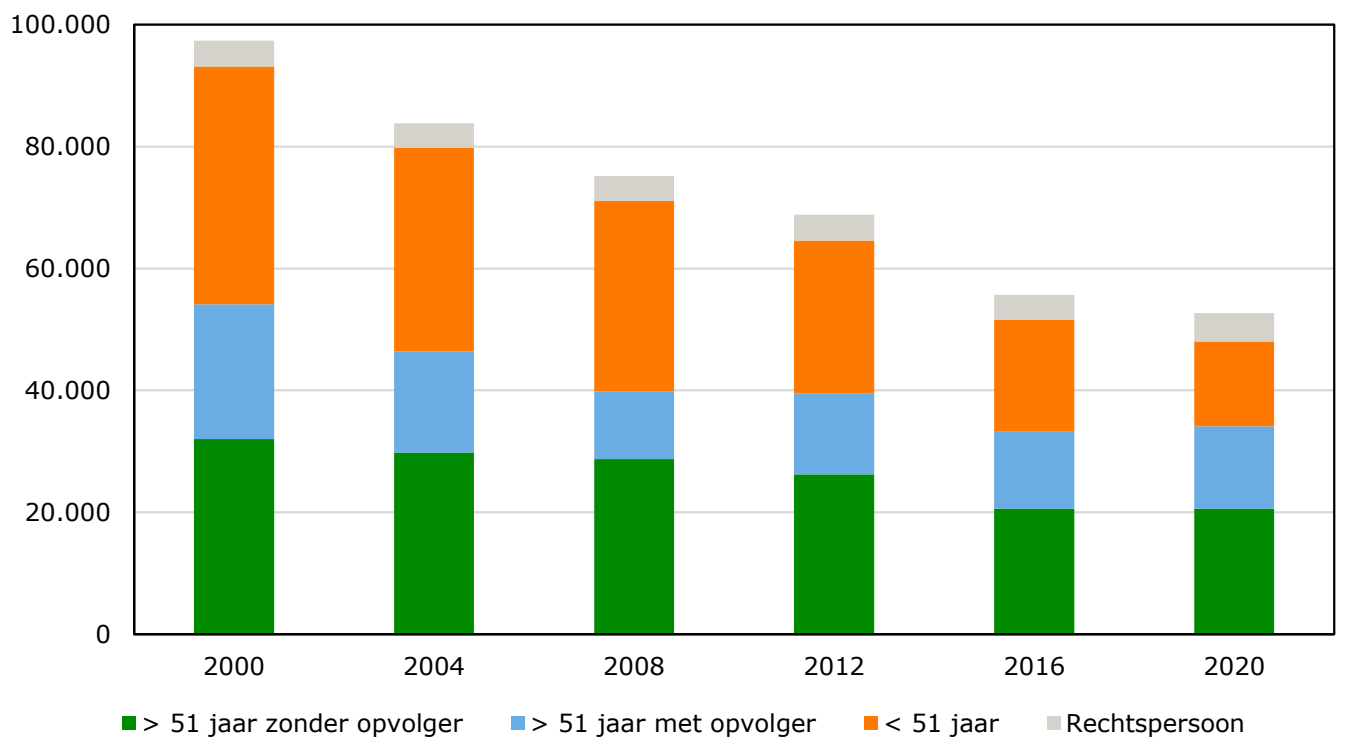

Figuur 4.6 Aantal bedrijven a) naar leeftijd bedrijfshoofd en opvolgingssituatie, 2000-2020 a) Bedrijven met rechtspersoonlijkheid zijn afzonderlijk opgenomen, omdat de vraag over opvolging niet wordt gesteld aan deze bedrijven. Zie ook kader Toelichting opvolgingssituatie.

Bron: CBS-Landbouwtelling, bewerking Wageningen Economic Research.

Hoger opvolgingspercentage; aantal bedrijven met een opvolger gelijk

In 2020 is op $40 \%$ van de 34.100 bedrijven met een bedrijfshoofd ouder dan 50 jaar, een opvolger aanwezig (tegen 34\% in 2012 en 38\% in 2016). Het aantal bedrijven met een opvolger is met 13.500 vrijwel gelijk aan dat in 2012. Het aantal bedrijven zonder opvolger is gedaald van 26.200 in 2012 tot 20.600 in 2020 (figuur 4.6).

\section{Toelichting opvolgingssituatie}

In de Landbouwtelling wordt eens in de vier jaar gevraagd of er een bedrijfsopvolger aanwezig is. Deze vraag wordt vanaf 2016 gesteld aan bedrijfshoofden van 51 jaar of ouder (voor die tijd was dat 50 jaar) met een bedrijf met als rechtsvorm een natuurlijk persoon. De opvolgersvraag wordt niet gesteld aan de rechtspersonen, vandaar dat deze groep bedrijven apart is opgenomen in figuur 4.6. Bij een bedrijfsvoering die uit meerdere personen bestaat, is gevraagd naar de leeftijd van het bedrijfshoofd met de grootste zakelijke en bedrijfsmatige verantwoordelijkheid. Als de bedrijfshoofden evenveel verantwoordelijkheid dragen, is gevraagd naar de leeftijd van de oudste ondernemer.

\section{Toelichting rechtsvorm}

De 52.700 land- en tuinbouwbedrijven die Nederland in 2020 telde, worden in overgrote mate - 48.000 gevoerd in de vorm van eenmanszaken en samenwerkingsvormen, zoals maatschappen en vennootschappen onder firma. Een minderheid van 4.700 bedrijven ( $9 \%$ ) heeft de vorm van een rechtspersoon, vrijwel allemaal besloten vennootschappen. De rechtspersoon komt vooral voor in intensieve, minder sterk grondgebonden sectoren, zoals de (glas)tuinbouw en intensieve veehouderij. Vooral grotere bedrijven kiezen voor deze rechtsvorm in verband met aansprakelijkheid, belastingen en financieringsmogelijkheden.

\section{Meer opvolgers bij toenemende bedrijfsomvang}

De animo om een bedrijf over te nemen wordt vooral bepaald door de bedrijfsomvang en daarmee de verdiencapaciteit. Bij een toenemende omvang gemeten in Standaardverdiencapaciteit (SVC) ${ }^{36}$ stijgt het opvolgingspercentage sterk, van $23 \%$ op de zeer kleine bedrijven, $36 \%$ op de kleine, $54 \%$ op de middelgrote, $63 \%$ op de grote, tot $66 \%$ op de zeer grote bedrijven (zie figuur 4.7 ). De mogelijkheden om een bedrijf over te nemen hangen naast de verdiencapaciteit af van de ondernemerskwaliteiten,

\footnotetext{
${ }^{36}$ https://www.agrimatie.nl/PublicatiePage.aspx?subpubID =2525\&sectorID =2243\&themaID =2286\&indicatorID =3178
} 
toekomstperspectieven van de sector (markt) en de omgeving waarin het bedrijf opereert in verband met ontwikkelings- en/of uitbreidingsmogelijkheden.

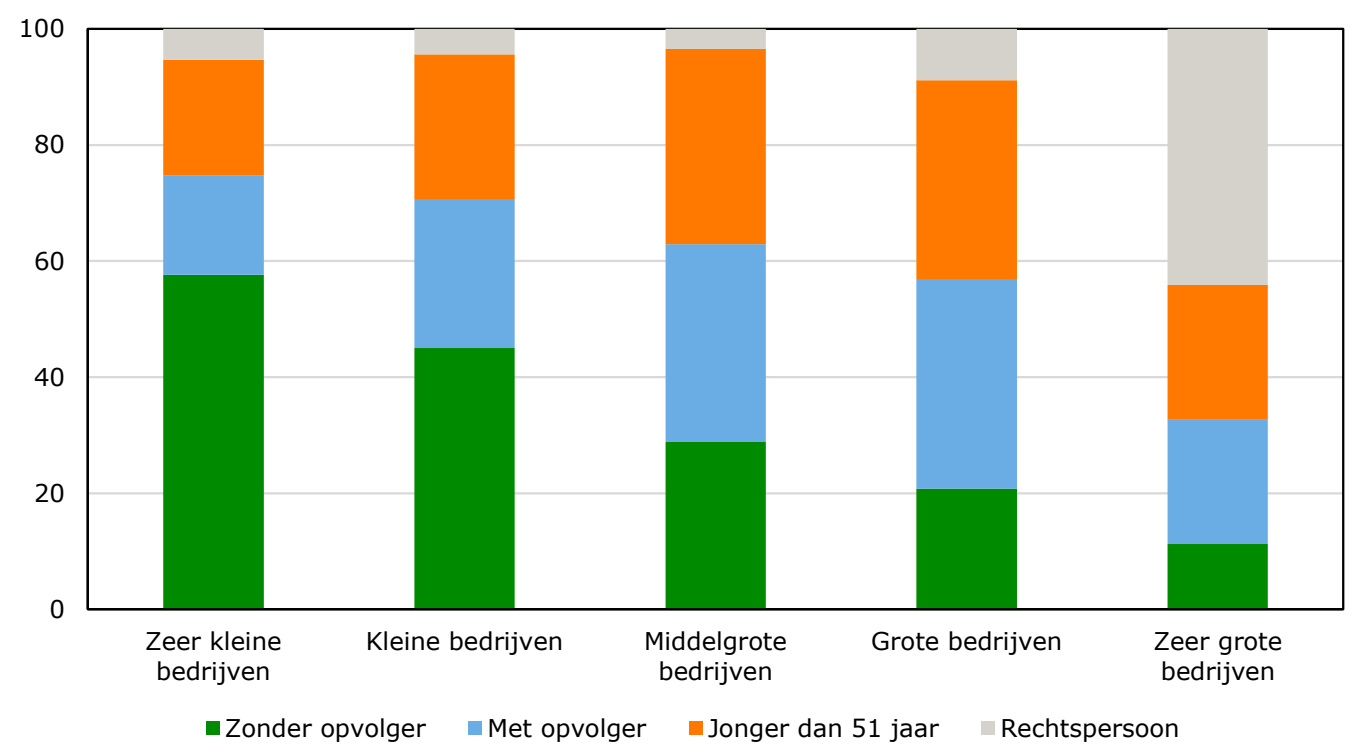

Figuur 4.7 Verdeling (\%) bedrijven a) naar leeftijd en opvolgingssituatie, en bedrijfsgrootte b), 2020 a) Bedrijven met rechtspersoonlijkheid zijn afzonderlijk opgenomen, omdat de vraag over opvolging niet wordt gesteld aan deze bedrijven.

b) Bedrijfsgrootte gemeten in Standaardverdiencapaciteit (SVC).

Bron: CBS-Landbouwtelling, bewerking Wageningen Economic Research.

Meeste opvolgers op melkveebedrijven

Naast de bedrijfsomvang speelt het bedrijfstype een rol in de belangstelling voor opvolging (figuur 4.8). Het opvolgingscijfer loopt uiteen van $25 \%$ op de overige graasdierbedrijven, $37 \%$ op de akkerbouwbedrijven tot $58 \%$ op de melkveebedrijven. De reden van dat laatste vrij hoge cijfer is onder meer dat veel oudere ondernemers zonder opvolger al eerder gestopt zijn met melken, waarbij het bedrijf vaak wordt voortgezet als graasdier- of akkerbouwbedrijf. Veruit de meeste overige graasdierbedrijven zijn (zeer) klein, en hebben veelal een wat ouder bedrijfshoofd zonder opvolger. Dat geldt in mindere mate ook voor de akkerbouwbedrijven. De glastuinbouw heeft met $19 \%$ het laagste opvolgingscijfer, maar in deze sector is bijna de helft van de bedrijven een rechtspersoon (figuur 4.8). Dat zijn over het algemeen zeer grote bedrijven. 


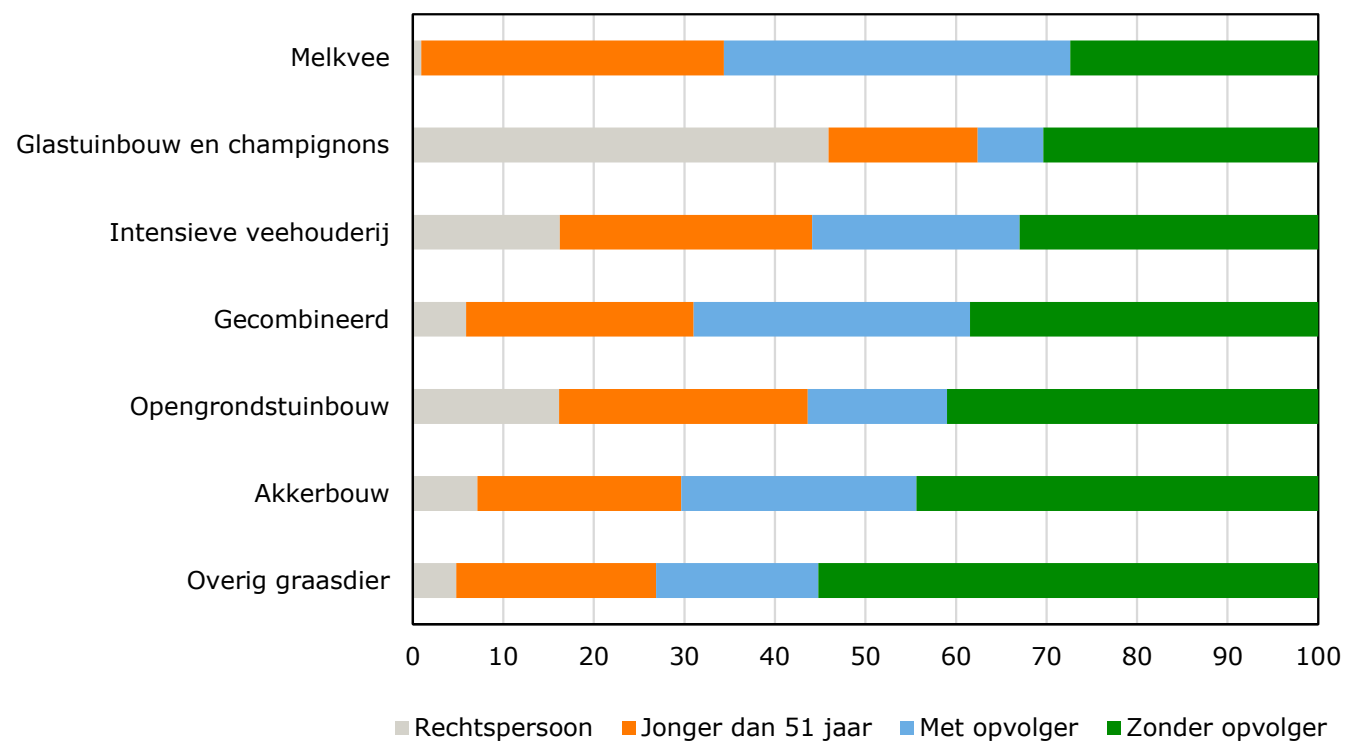

Figuur 4.8 Verdeling (\%) bedrijven a) naar leeftijd en opvolgingssituatie, en bedrijfstype, 2020 a) Bedrijven met rechtspersoonlijkheid zijn afzonderlijk opgenomen, omdat de vraag over opvolging niet wordt gesteld aan deze bedrijven.

Bron: CBS-Landbouwtelling, bewerking Wageningen Economic Research.

\section{Continuïteitspercentage vrij stabiel}

Een andere indicator voor de toekomstige ontwikkeling van het aantal bedrijven is het 'continuïteitspercentage'. Dit getal geeft een indruk van het deel van de bedrijven dat op de middellange termijn (zo'n vijftien jaar) naar verwachting zal worden voortgezet. In 2020 ligt het continuïteitspercentage in de land- en tuinbouw op 61\% (tegen 63\% in 2016). Tussen de verschillende bedrijfstypen loopt het continuïteitspercentage uiteen van $45 \%$ voor de overige graasdierbedrijven, tot $73 \%$ voor de melkveebedrijven (figuur 4.8).

Tot de bedrijven die naar verwachting op (middel)lange termijn worden voortgezet, worden gerekend bedrijven met een bedrijfshoofd jonger dan 51 jaar, bedrijven met een bedrijfshoofd van 51 jaar of ouder met een opvolger, en bedrijven met rechtspersoonlijkheid. De aanwezigheid van een opvolger wordt op deze laatste categorie bedrijven niet gevraagd. Maar aangezien het meestal zeer grote bedrijven zijn en het aantal tot 2016 vrij constant rond de 4.000 lag en in 2020 is toegenomen tot 4.700, lijkt de aanname dat deze bedrijven worden gecontinueerd een redelijke.

Voor de overige bedrijven - bedrijven met een bedrijfshoofd van 51 jaar of ouder zonder opvolger - is de veronderstelling dat die binnen een tijdsbestek van ongeveer vijftien zullen stoppen. Dat wil zeggen dat op de middellange termijn naar verwachting $39 \%$ van de bedrijven zal worden beëindigd, wat neerkomt op een gemiddelde jaarlijkse afname van 3,3\% (uitgaande van een periode van vijftien jaar). Dat ligt iets boven het niveau in de afgelopen vijftien jaar (2,9\%). Uiteraard geldt daarbij dat de situatie in de toekomst nog kan veranderen: niet alle bedrijven met een opvolger zullen daadwerkelijk worden opgevolgd en van de groep zonder opvolger kan later toch blijken dat er wel opvolging plaatsvindt. De ontwikkeling van het aantal bedrijven blijft in deze situatie nog steeds vooral bepaald worden door het stoppen bij generatiewisseling. Het is mogelijk dat milieumaatregelen en ruimtelijke claims voor wonen, werken, energie en natuur deze ontwikkelingen zullen versnellen.

\section{Verder lezen}

Op agrimatie staat een analyse van het potentiële aanbod landbouwgrond als gevolg van de bedrijfsopvolgingssituatie. ${ }^{37}$ Zie ook Opvolgingssituatie en toekomstig aanbod landbouwgrond. ${ }^{38}$

\footnotetext{
${ }^{37}$ https://www.agrimatie.nl/PublicatiePage.aspx?subpubID $=2525 \&$ sectorID $=2243 \&$ themaID $=7202$ \&indicatorID $\% 20=\% 202911$

${ }^{38}$ https://edepot.wur.nl/547322
} 


\subsubsection{Duurzame investeringen ${ }^{39}$}

Op verzoek van de Tweede Kamer wordt de duurzaamheidsindicator DP01 'investeringsniveau duurzame productiesystemen' jaarlijks gemonitord en opgenomen in de Rijksbegroting. Voor de duurzaamheidsindicator DP01 zijn de totale investeringen en de duurzame investeringen nodig om de verhouding te kunnen berekenen. De duurzame investeringen worden afgeleid van de subsidiabele investeringen en fiscale regelingen gericht op duurzame productiesystemen. In 2019 ging het hierbij net als voorgaande jaren om de Milieu-investeringsaftrek en de Willekeurige afschrijving milieu-investeringen (MIA/Vamil), de Energie-investeringsaftrek (EIA), de Regeling groenprojecten, de subsidie Energie-efficiëntie en hernieuwbare energie glastuinbouw (EHG) en de subsidie Marktintroductie energie-innovaties (MEI). Vanaf 2018 zijn de volgende nieuwe subsidieregelingen toegevoegd: de subsidie Demonstratie energieinnovatie (DEI), de Investeringssubsidie duurzame energie (ISDE) en de POP 3 - maatregel 4.1.1 'Fysieke investeringen voor innovatie en modernisering van agrarische ondernemingen' en de POP 3 maatregel 4.1.2 jonge landbouwersregeling (JoLa). De totale investeringen zijn exclusief investeringen in grond, immateriële activa (productierechten), woningen en plantopstanden, gebaseerd op het Bedrijveninformatienet. Omdat de indicator DP01 alleen gericht is op duurzame productiesystemen en de regelingen/subsidies geen betrekking hebben op bovengenoemde uitzonderingen, worden die investeringen in de totale investeringen buiten beschouwing gelaten.

Het aandeel duurzame investeringen in 2019 komt uit op 17\%; een lichte stijging van 1\% ten opzichte van 2018 en onder het gemiddelde in dit decennium van 27\% (figuur 4.9). In de Rijksbegroting was een streefwaarde van 30\% opgenomen. De totale investeringen in agrarische productiemiddelen zijn in 2019 ten opzichte van 2018 met 16\% gestegen tot 3,7 mld. euro, terwijl de totale investeringen in duurzame productiesystemen waarvoor subsidie of fiscale aftrek is aangevraagd met $27 \%$ zijn gestegen tot $629 \mathrm{mln}$. euro (zie figuur 4.9).

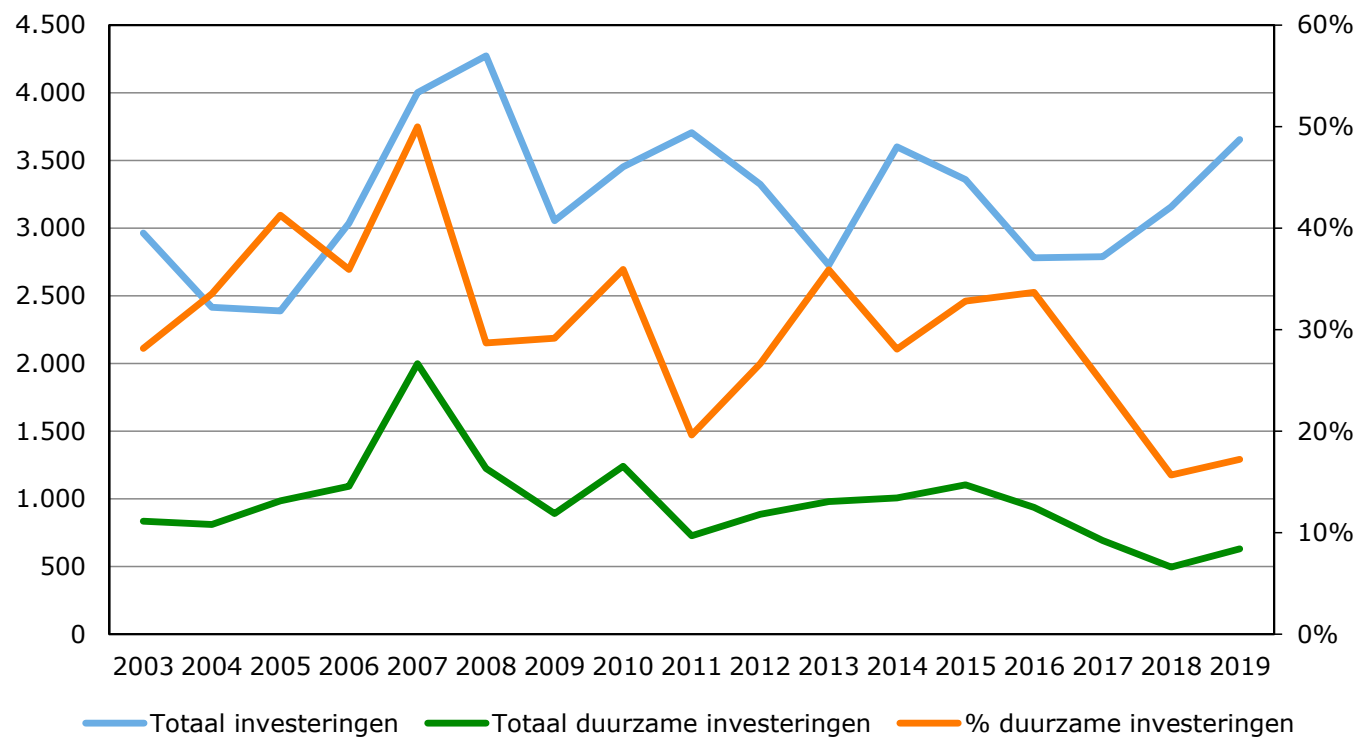

Figuur 4.9 Totaal investeringen a) in de landbouw, tuinbouw en visserij en totaal duurzame investeringen (in mln. euro) en aandeel duurzame investeringen (\%), 2003-2019

a) exclusief investeringen in grond, immateriële activa, woningen en plantopstanden.

De stijging in de omvang van de duurzame investeringen is grotendeels toe te schrijven aan hogere investeringen in duurzame stallen (vooral varkensstallen) (onderdeel van MIA/Vamil). Daarnaast is het bedrag voor de regeling Fysieke investeringen voor innovatie en modernisering - maatregel 4.1.1 onder POP3 in 2019 verdubbeld en zijn onder dezelfde maatregel dankzij een aanvullende fysieke regeling voor

\footnotetext{
39 Deze bijdrage is gebaseerd op Van der Meulen et al., 2021: Investeringsniveau duurzame productiesystemen; Duurzaamheidsindicator (DP01) in de Rijksbegroting 2022. Wageningen, Wageningen Economic Research, Nota 2021-143.
} 
vleeskalverhouders de investeringen in diervriendelijke kalverstallen flink toegenomen in 2019. In de periode 2013-2016 lag het bedrag aan duurzame investeringen jaarlijks nog rond de $1 \mathrm{mld}$. euro. In die periode ging er relatief veel geld vanuit Regeling Groenprojecten naar biologische landbouw en vanuit MIA/Vamil naar Groen Label Kassen en duurzame stallen (van der Meulen et al., 2021).

\subsubsection{Innovatie}

De meeste ondernemers op land- en tuinbouwbedrijven investeren regelmatig in vernieuwingen op het bedrijf. Door vervanging van verouderde machines of gebouwen zal de moderniteit van de bedrijven omhoog gaan. Als de ondernemer investeert in machines of gebouwen die al langere tijd op de markt zijn is dit voor het bedrijf wel een vernieuwing, maar geen innovatie.

\section{Innovatoren en volgers}

Van Galen en Ge (2008) maken onderscheid naar innovatoren en volgers. Innovatoren zijn ondernemers die: 'als eerste in Nederland een nieuw product op de markt gebracht of nieuwe procestechnologie geïmplementeerd' hebben. Vroege volgers hebben een 'procesvernieuwing geïmplementeerd, niet als eerste maar bij de eerste $25 \%$ van de bedrijven in de sector'. Bedrijven die wel vernieuwen maar in een later stadium zijn de late volgers. Samen vormen de drie groepen de groep 'vernieuwers'.

\section{Typen innovaties en drijfveren}

Er kan onderscheid worden gemaakt in typen innovaties. Technologische innovaties zijn veranderingen in de processen of producten op het bedrijf, waarbij de ondernemer als eerste in Nederland dit doorvoert. Voorbeelden van procesinnovaties die zijn doorgevoerd zijn bijvoorbeeld de inzet van GPS-gestuurde apparatuur of drones waarmee nauwkeuriger gewerkt kan worden en bespaard kan worden op inputs als meststoffen en gewasbeschermingsmiddelen. Ook moderne sorteer- en inpakmachines met camera's zijn voorbeelden van procesvernieuwingen. De vernieuwingen kunnen bijdragen aan een efficiëntere productie en een lagere kostprijs. Een andere reden om te vernieuwen kan zijn om beter aan te sluiten bij de wensen van consumenten. De verpakkingsmachines kunnen daaraan bijdragen door verpakkingen waarin de producten langer vers blijven of waarvan de hoeveelheid beter is afgestemd op behoeften van consumenten. In dit geval is er naast procesinnovatie ook sprake van productinnovatie. Andere vormen van productinnovatie zijn groenten- of fruitrassen die bijvoorbeeld qua smaak of houdbaarheid onderscheidend zijn van bestaande rassen. In dit geval is niet zo zeer kostenbesparing door efficiencyverbetering de aanleiding voor de innovaties als wel het verhogen/behouden van een goede marge. Andere belangrijke drijfveren voor innovaties zijn: arbeidsbesparing/verbetering van arbeidsomstandigheden. In de veehouderij is daarnaast het verbeteren van het dierenwelzijn en -gezondheid belangrijk (Van der Meer en Van Galen, 2017).

\section{Redenen voor vernieuwing}

Om inzicht te krijgen in het aandeel land- en tuinbouwbedrijven dat vernieuwingen en innovaties doorvoert, houdt Wageningen Economic Research jaarlijks een enquête onder haar deelnemers van het Bedrijveninformatienet. In deze enquête wordt gevraagd of de ondernemer in het voorgaande jaar een vernieuwing heeft doorgevoerd en zo ja hoe vernieuwend dit was in Nederland (volgens de eigen inschatting van de ondernemer). Figuur 4.10 geeft het aandeel koplopers (innovatoren en vroege volgers) weer. Het aandeel innovatoren blijft gedurende de weergegeven periode onder de $2 \%$. Het aandeel koplopers schommelt, met een maximaal aandeel van $11 \%$ van de bedrijven in 2015 . De glastuinbouw leverde hieraan een belangrijk bijdrage, dankzij de financiële armslag die de sector destijds had. Na 2013 kwamen de inkomens die gerealiseerd werden in de glastuinbouw in de lift. In de meeste jaren behoort de glastuinbouwsector tot de sector met de meeste koplopers. In 2019 was 13\% van de koplopers een glastuinbouwbedrijf (Van Galen en Van der Meer, 2020).

Niet enkel de financiële ruimte bepaalt of er in een sector vernieuwingen worden doorgevoerd. In 2014 bijvoorbeeld, was het aandeel vernieuwende bedrijven in de melkveehouderij relatief hoog. Melkveehouders anticipeerden op het wegvallen van het melkquotum en investeerden in nieuwe machines om de capaciteit van het bedrijf uit te breiden. Een ander voorbeeld van regelgeving door de overheid die kan leiden tot een toename van vernieuwing in een sector deed zich voor in de pluimveehouderij. De vernieuwingen namen toe in de laatste jaren voordat de verplichting voor het gebruik van emissiearme stallen van kracht werd. Innovaties kunnen ook ontstaan uit nood. De huidige hoge gasprijzen zouden voor glastuinbouwbedrijven 
een reden kunnen zijn om innovaties door te voeren op het gebied van energiemanagement of teeltwijze. Verlagen van de kostprijs is voor glastuinbouwbedrijven een belangrijke drijfveer om vernieuwingen door te voeren (Van der Meer en Van Galen, 2017).

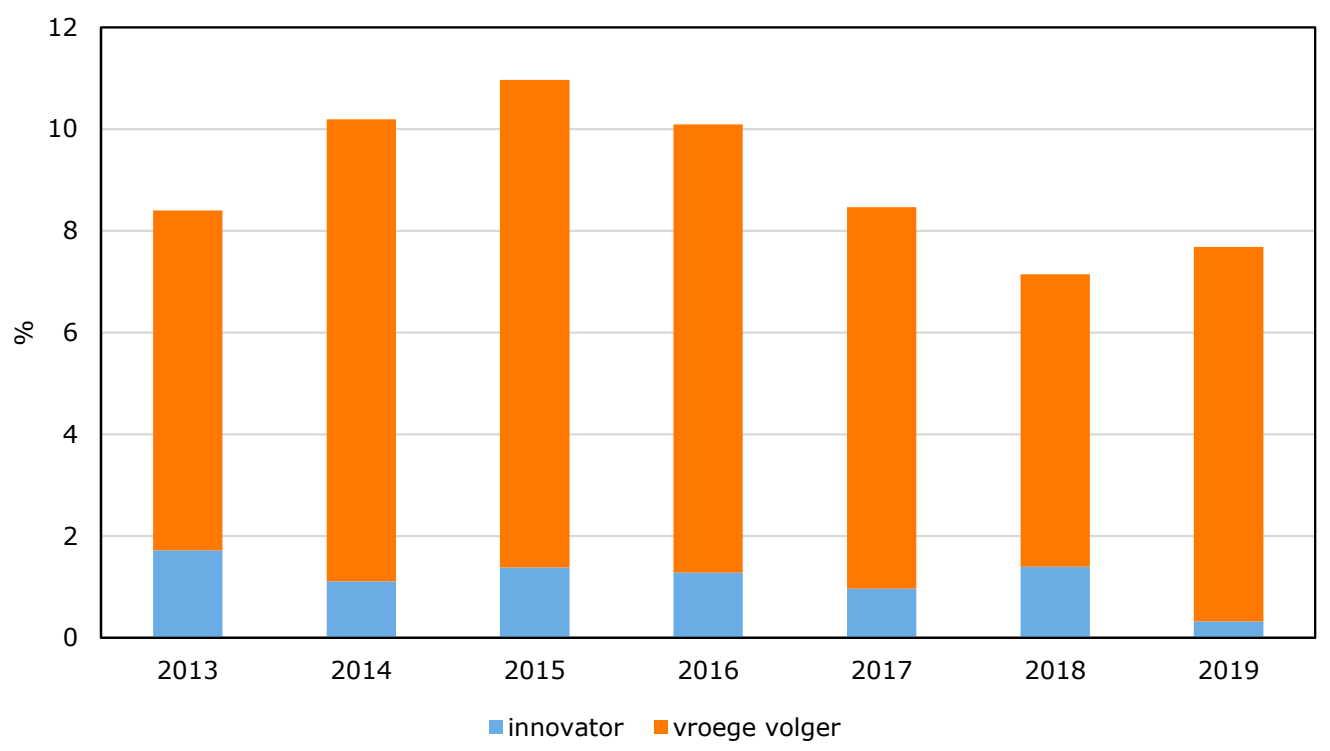

Figuur 4.10 Aandeel koplopers (innovatoren en vroege volgers) in de land- en tuinbouw, 2013-2019 Bron: Innovatie-enquête, Wageningen Economic Research.

\subsection{Ruimtelijke verdeling}

Er zijn grote verschillen in de economische intensiteit (gemeten in Standaardopbrengst (SO), zie kader) van de land- en tuinbouw tussen regio's (figuur 4.11). De glastuinbouw levert met de teelt van bloemen, planten en groenten een hoge standaardomzet per $\mathrm{km}^{2}$. Zodoende zijn de vestigingslocaties van deze sector duidelijk herkenbaar op de kaart van Nederland. De concentratie in de Greenports Westland/Oostland, Aalsmeer en omstreken en Venlo en omstreken zorgt voor een grote economische intensiteit. Ten opzichte van 2017 is de economische betekenis door de glastuinbouw in de Bommelerwaard (Gelderland) en in Flevoland licht toegenomen onder andere door hogere SO-norm per eenheid product. De tuinbouw (glastuinbouw, bloembollenteelt en vollegrondsgroente) zorgt ook voor grote economische activiteit in de kop van NoordHolland. De vleeskalverhouderij en pluimveehouderij dragen bij aan de grote economische intensiteit van de Gelderse Vallei. In Zuidoost-Nederland zijn economische concentraties zichtbaar vanuit de varkenshouderij en pluimveehouderij. De lagere intensiteiten behoren toe aan de grondgebonden sectoren (melkveehouderij en akkerbouw). 


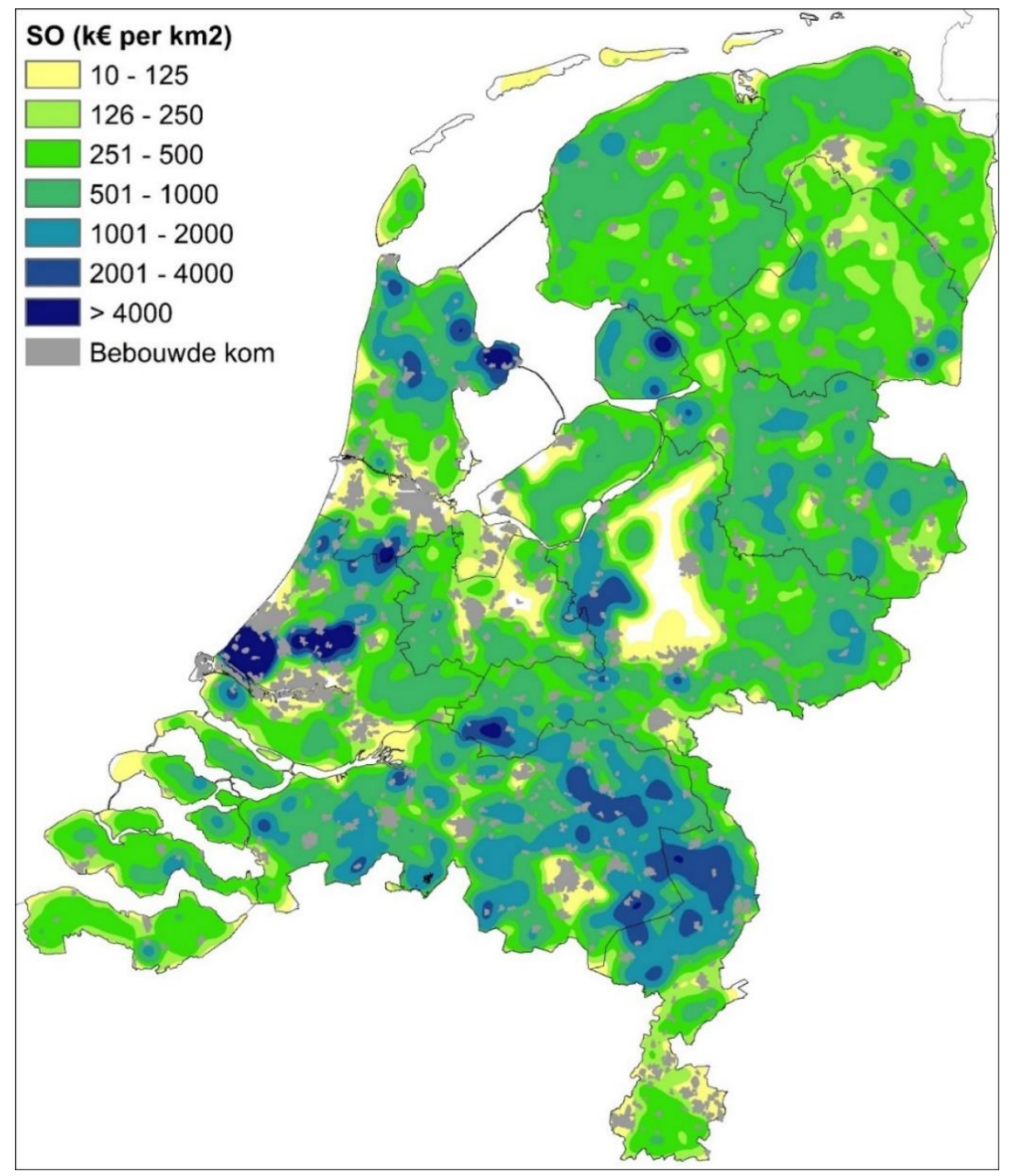

Figuur 4.11 Ruimtelijke verdeling land- en tuinbouw gemeten in Standaardopbrengst (1.000 euro per $\left.\mathrm{km}^{2}\right)$, 2020

Bron: CBS Landbouwtelling 2020, bewerking Wageningen Economic Research.

Op de Waddeneilanden, de Veluwe en de Utrechtse Heuvelrug is er eveneens een lagere intensiteit vanwege bos en natuurgebied.

Het totale ruimtebeslag van de land- en tuinbouw neemt langzaam af. In 2020 bedroeg het totale areaal cultuurgrond 1,81 mln. ha ten opzichte van 1,98 mln. ha in 2000 . Dit is twee derde van het totale landareaal in Nederland. De landbouw verliest langzaam terrein aan natuur, recreatie en 'rode functies' als wonen en werken, bijvoorbeeld in de Randstad. Gedurende de laatste 20 jaar gaat het om gemiddeld ruim 0,4\% per jaar afname.

De grootste sectoren in aantal ha gemeten zijn de grondgebonden sectoren melkvee en akkerbouw. Het houden van dieren en het telen van gewassen gaat gepaard met een lagere standaardomzet per $\mathrm{km}^{2} \mathrm{dan}$ de activiteiten in de niet-grondgebonden sectoren. Maar ook binnen die sectoren zijn verschillen in economische intensiteit tussen regio's waarneembaar (zie voor meer details agrimatie.nl). 
De kaart van de regionale verdeling is weergegeven in euro Standaardopbrengst (SO) per $\mathrm{km}^{2}$ grondoppervlakte. Op agrimatie.nl zijn voor de afzonderlijke bedrijfstypen in de land- en tuinbouw soortgelijke kaarten beschikbaar. Op deze manier wordt de verdeling naar economische intensiteit tussen regio's per sector inzichtelijk gemaakt. De Standaardomzet wordt gebruikt als maatstaf om de omvang en specialisatiegraad van bedrijven vast te stellen. Per agrarisch product wordt een SO-norm vastgesteld. De SO-norm is een gestandaardiseerde opbrengst (in euro) per ha of per dier die met een gewas of diercategorie gemiddeld op jaarbasis wordt behaald.

Opbrengsten uit bedrijfstoeslagen, subsidies en multifunctionele activiteiten zijn niet in de norm meegenomen. Voor biologische productiemethoden worden dezelfde SO-normen gehanteerd als voor gangbare productiemethoden. Voor de Landbouwtelling van 2020 zijn de nieuwe normen van prijsniveau 2017 gebruikt. De nieuwe normen zijn gebaseerd op kg opbrengsten en prijzen uit de jaren 2015-2019.

\subsection{Biologische landbouw}

Het aantal gecertificeerde biologische land- en tuinbouwbedrijven is in Nederland in 2020 ten opzichte van 2019 met 3\% toegenomen tot 2.019; in 2019 was de toename nog 6\% ten opzichte van 2018 (tabel 4.6). Tussen 2010 en 2015 is het aantal gecertificeerde biologische bedrijven rond de 1.500 gestabiliseerd. Vanaf 2016 groeit het aantal bedrijven weer, tot 2.019 bedrijven in 2020 ( $+38 \%$ ten opzichte van 2010 ). Wel is er de laatste jaren sprake van afvlakking in de groei. In 2020 maken biologische land- en tuinbouwbedrijven $4 \%$ uit van alle land- en tuinbouwbedrijven. Het aantal bedrijven in omschakeling in 2020 is voor het vierde jaar op rij gedaald, tot onder de 100.

Het gecertificeerde areaal steeg in 2020 met 7\% tot 74.282 ha. Het gecertificeerde areaal neemt al langer in omvang toe, van 51.150 ha in 2010 tot 74.282 ha in 2020 (+45\%). Ook in de biologische landbouw is sprake van enige schaalvergroting. In $2020 \mathrm{kwam}$ het geregistreerde areaal per bedrijf uit op gemiddeld 37 ha, een toename van 1,2 ha. ten opzichte van het voorgaande jaar. De hectares in omschakeling, de laatste jaren circa 5.000 ha per jaar, zijn niet alleen van nieuwe, omschakelende bedrijven, maar ook van bestaande gecertificeerde bedrijven die nieuwe grond omschakelen en bedrijven samenvoegen. Hierdoor groeit het biologisch areaal sterker dan het aantal biologische bedrijven (Skal, 2021).

Tabel 4.6 Biologische land- en tuinbouw, 2010-2020

\begin{tabular}{|c|c|c|c|c|c|c|c|}
\hline & 2010 & 2015 & 2016 & 2017 & 2018 & 2019 & 2020 \\
\hline $\begin{array}{l}\text { Aantal gecertificeerde } \\
\text { bedrijven }\end{array}$ & 1.462 & 1.508 & 1.586 & 1.750 & 1.849 & 1.952 & 2.019 \\
\hline $\begin{array}{l}\text { Aantal bedrijven in } \\
\text { omschakeling }\end{array}$ & 138 & 117 & 245 & 180 & 161 & 124 & 96 \\
\hline Aantal geregistreerde bedrijven & 1.600 & 1.625 & 1.831 & 1.930 & 2.010 & 2.076 & 2.115 \\
\hline Areaal gecertificeerd (in ha) & 51.150 & 56.729 & 58.446 & 60.449 & 66.623 & 69.349 & 74.282 \\
\hline Areaal in omschakeling (in ha) & 2.761 & 2.391 & 3.319 & 9.067 & 4.728 & 5.856 & 5.382 \\
\hline Totaal geregistreerde areaal (in & 53.911 & 59.120 & 61.765 & 69.516 & 71.351 & 75.205 & 79.664 \\
\hline
\end{tabular}

ha)

Bron: Stichting Skal Biocontrole, bewerking Wageningen Economic Research.

Van het totaal gecertificeerde biologische areaal ligt 16\% (circa 12.250 ha) in de provincie Flevoland. Gelderland en Friesland volgen met beide 12\%. In Noord-Brabant gaat het om $10 \%$ en in Noord-Holland, Drenthe en Overijssel om circa $9 \%$. In de provincie Groningen ligt $7 \%$ van het areaal biologisch. De kleinste aandelen vinden we terug in de provincies Zuid-Holland en Utrecht met beiden $5 \%$ en Limburg en Zeeland met 3\% (circa 2.550 ha) (Skal, 2021). Het biologische areaal bestaat grotendeels uit grasland (70\%). Daarnaast is $21 \%$ akkerbouwgrond, $5 \%$ tuinbouwgrond en $4 \%$ groenvoedergewassen (clo, 2021).

Stabilisatie biologische veestapel

In 2020 telde de biologische veestapel ruim 4,1 mln. dieren; een vergelijkbaar aantal als in 2019 (CBSLandbouwtelling). Het aandeel biologisch in de totale veestapel in Nederland bedraagt 3,4\%. De biologische 
veestapel bestaat overwegend uit leghennen (ruim 3,6 mln. dieren). De geitenhouderij heeft met een aandeel van $9 \%$ het grootste aandeel biologische dieren, gevolgd door de leghennenhouderij met $8 \%$. In de leghennenhouderij is het aandeel biologische bedrijven met ruim $25 \%$ een stuk groter dan gemiddeld. Deze biologische bedrijven houden gemiddeld minder leghennen dan de reguliere leghennenbedrijven. In de melkveehouderij is $2,6 \%$ van het aantal runderen biologisch, een lichte toename ten opzichte van vorig jaar. Het aantal biologisch gehouden varkens is, na een forse toename in 2019, in 2020 gedaald met 4.000 stuks tot $102.000(0,8 \%$ van de totale varkensstapel). Belangrijkste reden voor de teruggang is de deelname van een aantal biologische varkenshouders aan de Subsidieregeling sanering varkenshouderij (Srv)

(www.nieuweoogst.nl).

Nederland heeft kleiner aandeel biologisch areaal dan gemiddeld in de EU In de Europese Unie is het biologische areaal in 2019 met circa 6\% gegroeid tot 8,1\% van het landbouwareaal (in Nederland 3,7\% in 2019). Oostenrijk (26\%), Estland (22\%) en Zweden (20\%) zijn de top-3 landen van de EU wat betreft aandeel biologisch areaal. In de ons omringende landen ligt het aandeel biologisch op circa 10 à $11 \%$ in Duitsland en Denemarken, en rond de $7 \%$ in België en Frankrijk. Spanje heeft met 2,4 mln. ha absoluut gezien het grootste biologische areaal in de EU, gevolgd door Frankrijk met $2,2 \mathrm{mln}$. ha en Italië met $2 \mathrm{mln}$. ha; dit zijn vooral wijngaarden, olijfbomen en noten. Deze landen zijn hiermee goed voor $45 \%$ van het totale biologisch areaal in de EU. Tellen we het areaal van 1,6 mln. ha in Duitsland daarbij, dan herbergen deze 4 landen meer dan de helft - $56 \%$ - van het biologische areaal in de EU (FiBL en IFOAM, 2021).

Meer informatie beschikbaar op agrimatie.nl

Voor de biologische melkveebedrijven en de biologische akkerbouw-groentenbedrijven zijn op jaarbasis economische cijfers, evenals structuur- en duurzaamheidskenmerken voorhanden vanuit het Bedrijveninformatienet. ${ }^{40}$ Voor de overige sectoren ontbreekt specifieke informatie over de biologische bedrijven.

\subsection{Multifunctionele landbouw}

In 2020 waren er ruim 22.000 agrarische bedrijven met een of meer verbredingsactiviteiten; $42 \%$ van het totale aantal bedrijven (tabel 4.7). Dit aandeel ligt hoger dan in voorgaande metingen; in 2010 bedroeg het aandeel nog 28\%. Meer dan een derde van de bedrijven was in 2020 actief in meer dan één verbredingsactiviteit. De grootste verbredingsactiviteit is en blijft agrarisch natuur- en landschapsbeheer met 8.200 bedrijven. Ten opzichte van eerdere metingen was er een sterke toename te zien bij de bedrijven die zich toeleggen op de productie van duurzame energie voor derden. Ook verkoop van landbouwproducten aan huis noteerde een forse toename, deels door verruiming in de definitie van deze activiteit met verkoop via maximaal 1 tussenschakel.

${ }^{40}$ https://www.agrimatie.nl/ThemaResultaat.aspx?subpubID=2232\&themaID=2286\&indicatorID =3586 en www.agrimatie.nl 
Tabel 4.7 Aantal landbouwbedrijven met verbredingsactiviteit, 2010-2020

\begin{tabular}{|c|c|c|c|c|}
\hline Activiteit & 2010 & 2013 & 2016 a) & 2020 \\
\hline Aquacultuur & 24 & 25 & 9 & 11 \\
\hline Loonwerk voor derden & 4.050 & 4.071 & 3.586 & 5.437 \\
\hline Stalling van goederen/dieren & 2.924 & 2.809 & 1.955 & 2.990 \\
\hline Verwerking landbouwproducten & 1.123 & 1.041 & 734 & 1.167 \\
\hline Opwekking duurzame energie voor levering aan derden & 897 & 1.222 & 994 & 3.508 \\
\hline Agrarische kinderopvang & 184 & 219 & 142 & 179 \\
\hline Agrotoerisme & 2.832 & 2.777 & 1.836 & 1.995 \\
\hline Boerderijeducatie & 646 & 798 & 686 & 1.004 \\
\hline Agrarisch natuur- en landschapsbeheer & 7.922 & 7.404 & 5.268 & 8.190 \\
\hline Verkoop landbouwproducten aan huis, totaal b) & 3.043 & 3.127 & 2.641 & 7.234 \\
\hline Rechtstreekse verkoop aan consument, met max 1 tussenschakel & & & & 3.833 \\
\hline Rechtstreekse verkoop aan consument, zonder tussenschakel & & & & 5.127 \\
\hline Zorglandbouw & 865 & 874 & 614 & 701 \\
\hline Eindtotaal b) & 19.915 & 21.603 & 15.416 & 22.053 \\
\hline Aandeel bedrijven met verbreding in totaal (in \%) & 28 & 32 & 28 & 42 \\
\hline
\end{tabular}

a) In 2016 is de vraag over verbreding niet voorgelegd aan de rechtspersonen (3.876 bedrijven) en de persoonlijke ondernemingen ( 972 bedrijven) waar de dagelijkse leiding niet bij het bedrijfshoofd lag. Hiermee geven de cijfers over 2016 een onderschatting van de verbredingsactiviteiten en zijn deze niet direct te vergelijken met de andere jaren; b) het totaal aantal bedrijven met verbredingsactiviteiten is niet de som van de aantallen per activiteit. Meerdere bedrijven hebben meer dan één activiteit per bedrijf. Bron: CBS Landbouwtelling.

De meeste bedrijven met verbreding, ongeveer 9.500, zijn overige land- en tuinbouwbedrijven (overige graasdieren-, hokdieren-, tuinbouwbedrijven). Dit zijn bedrijven die niet gespecialiseerd zijn in één tak van de landbouw. Met een aandeel van $48 \%$ zijn de melkveebedrijven relatief het meest actief met verbredingsactiviteiten. Regionaal gezien liggen in absolute zin de meeste bedrijven met verbreding in OostNederland ( 6.460 bedrijven). Procentueel is West-Nederland (Noord- en Zuid-Holland, Zeeland en Utrecht) het sterkst vertegenwoordigd; bijna 1 op de 2 bedrijven doet daar aan verbreding. Landelijk gezien was in 2020 op 3.800 bedrijven (17\%) het aandeel van de omzet uit verbredingsactiviteiten meer dan $50 \%$ van de totale omzet. Bij 56\% van de bedrijven met verbreding was de bijdrage uit verbreding aan de omzet op het bedrijf minder dan $10 \%$.

Voor een zestal verbredingsactiviteiten die vallen onder de definitie van multifunctionele landbouw (agrarische kinderopvang, agrotoerisme, boerderijeducatie, agrarisch natuur- en landschapsbeheer, boerderijverkoop en zorglandbouw) zijn omzetcijfers bekend. Volgens de laatst bekende cijfers over 2018 bedroeg de omzet $887 \mathrm{mln}$. euro. Tussen de zes onderscheiden multifunctionele activiteiten zijn er grote verschillen in omzet. Boerderijverkoop was in 2018 met ruim $270 \mathrm{mln}$. euro de grootste activiteit, gevolgd door zorglandbouw (250 mln. euro) en recreatie (221 mln. euro). Agrarische kinderopvang was goed voor bijna $80 \mathrm{mln}$. euro omzet en agrarisch natuurbeheer $66 \mathrm{mln}$. euro. Boerderijeducatie levert met minder dan $1 \mathrm{mln}$. euro de kleinste bijdrage (Van der Meulen et al., 2019). Begin 2022 worden door Wageningen Research nieuwe omzetcijfers gepresenteerd over 2020.

Over de bijdrage van de verbredingsactiviteiten aan het inkomen van het bedrijf zijn geen gegevens bekend. Op verzoek van het ministerie van LNV wordt door Wageningen Economic Research hiernaar onderzoek gedaan, in het voorjaar van 2022 worden de resultaten van dit onderzoek gepubliceerd.

\section{Korte ketens}

Uit de CBS-Landbouwtelling bleek dat er op de peildatum 1 april 20207.234 agrarische bedrijven waren die (een deel van de) door hen geproduceerde of bewerkte voedsel- en sierteeltproducten afzetten via een korte keten, dat wil zeggen: direct aan de consument, of met één tussenschakel (zie kader voor de definitie). De bedrijven met een afzet via de korte keten vertegenwoordigen bijna $14 \%$ van alle primaire agrarische bedrijven. De totale opbrengst door verkoop via korte ketens op agrarische bedrijven (hierna korteketenbedrijven genoemd) kwam op minimaal 1,36 mld. euro in de periode april 2019 tot en met maart 2020. Hierin is het effect van Covid-19 nog nauwelijks meegenomen (Venema et al., 2021). 
De gevolgen van de coronacrisis voor de korte ketenverkoop zijn afhankelijk van het soort product en het kanaal waar de ondernemer aan levert. De verkoop van bloemen en planten ondervond hinder van de sluiting van tuincentra dit jaar. Boeren of tuinders die direct aan de horeca leveren, leden onder de horecasluiting. Maar de boeren en tuinders die via speciaalzaken de consumenten bereiken, profiteerden juist van de veranderende consumentenbestedingen (Menkveld, 2021).

Het aandeel korteketenbedrijven in het totaal aantal bedrijven is het hoogst voor fruitteelt, glastuinbouw en de groep overig tuinbouw. De melkveehouderij heeft absoluut gezien het grootste aantal korteketenbedrijven. Dit hangt onder andere samen met 'zelfzuivelaars': dit zijn melkveebedrijven die hun eigen melk verwerken tot kaas, yoghurt, ijs etc. De aanwezigheid van relatief veel korteketenbedrijven in een bedrijfstype heeft sterk te maken met het feit dat er geen of nauwelijks bewerking nodig is voordat het product aan de eindconsument kan worden verkocht. Dit geldt in sterke mate voor eieren en fruit, maar ook voor meerdere groenten, planten en bloemen (Venema et al., 2021).

\section{Definitie van 'Korte keten'}

In de Landbouwtelling is de volgende EU-definitie voor korte ketens aangehouden: Geen of maximaal één schakel (toeleveringsketenpartij) tussen producent (boer/tuinder) en consument. Rechtstreekse verkoop betreft de verkoop langs de weg, op de markt, via internet, via een eigen winkel en bezorging aan huis. Bij één schakel gaat het om directe leveringen aan retail, horeca \& catering en markten.

In de groep bedrijven met een jong bedrijfshoofd ( $<40$ jaar) bevinden zich relatief de meeste korteketenbedrijven (17\%). Toch zet ook één op de tien 65-plussers af via korte ketens. Er is een sterke relatie tussen afzet van producten via korte ketens en multifunctionele activiteiten. Zo verkoopt $30 \%$ van de bedrijven met agrotoerisme en meer dan een derde van de zorgboerderijen ook producten via een korte keten. De bedrijven met educatieactiviteiten scoren het hoogst in het aandeel met korteketenbedrijven (43\%). Absoluut gezien bevinden de meeste korteketenbedrijven zich in de provincie Noord-Brabant, gevolgd door Gelderland en Zuid-Holland. Procentueel gezien scoort Limburg het hoogst met een aandeel van $20 \%$ van alle agrarische bedrijven die afzetten via een korte keten, gevolgd door Noord- en Zuid-Holland (19\%). Het aandeel in de provincies Groningen, Friesland en Overijssel groeit, maar blijft nog onder de $10 \%$. Per provincie zijn er afzonderlijke factsheets opgesteld (Venema et al., 2021).

Voor verdere ontwikkeling van korte ketens liggen er op het terrein van efficiëntere logistiek, toegankelijkheid van subsidies, kennisontwikkeling en oog voor meervoudige waardecreatie belangrijke uitdagingen. Hierbij zullen boer/tuinder, overheden en ketenpartijen samen de verantwoordelijkheid moeten nemen. Dit zijn de belangrijkste uitkomsten van provinciale sessies in dit onderzoek dat zich richt op de productiekant van korte ketens (Venema et al., 2021). Ook de ontwikkeling van de vraagkant is belangrijk voor verdere groei (zie ook 'Korteketenproducten in Nederland' van Tacken et al., 2021). In het onderzoek van Tacken et al. (2021) wordt een aantal obstakels (waaronder professionaliteit) benoemd bij het vergroten van het aandeel korte ketens in de markt. Ook worden een drietal stappen beschreven die het marktaandeel van korte ketens kunnen vergroten.

Recentelijk heeft de Taskforce Korte Ketens ${ }^{41}$ (TKK) in het adviesrapport Nationale Samenwerking korte keten (2021) gemaakt in opdracht van alle 12 provincies en het ministerie van LNV. In het rapport staan diverse aanbevelingen. Een van de adviezen is om de al bestaande afstemming tussen de provincies en het ministerie van LNV te intensiveren en om te zetten naar een bovenregionale samenwerking. Waarbij de uitvoering van deze samenwerking bij een onafhankelijke partij belegd gaat worden. Maar het belangrijkste is dat er een gezamenlijke meetbare doelstelling komt en één gezamenlijke definitie van korte keten. De provincies en het ministerie van LNV zijn nog in overleg over de implementatie van de adviezen uit het rapport.

${ }^{41}$ De Taskforce Korte Ketens is een initiatief van ondernemers in die korte keten, 150 bedrijven zijn erbij aangesloten. 


\subsection{Inkomensontwikkelingen}

\subsubsection{Sectorresultaten}

De productiewaarde van de akkerbouw is in 2020 met bijna 14,5\% afgenomen tot circa 2,8 mld. euro. Het volume steeg nog wel met gemiddeld zo'n 4,5\% maar de gemiddelde prijs is, voor het tweede opeenvolgende jaar, fors lager uitgekomen $(-18 \%)$. Het productievolume van een aantal belangrijke akkerbouwproducten steeg, zoals aardappelen $(+7 \%)$ en uien $(+15 \%)$. Er zijn in 2020 echter wel fors lagere prijzen gerealiseerd voor uien $(-38 \%)$ en aardappelen $(-30 \%)$. Met name de frietaardappelen realiseren fors lagere prijzen omdat een relatief groot deel van de frietaardappelen, als gevolg van de Covid-19-crisis en de daarmee gepaard gaande sluiting van restaurants en horeca, in het voer terecht is gekomen. De lage prijs voor de uien is het gevolg van vraag en aanbod die niet op elkaar waren afgestemd: de (buitenlandse) vraag naar uien betrof grote uien, het binnenlandse aanbod bestond echter overwegend uit fijne uien. Voor zowel aardappelen en uien is gerekend met een gemiddelde prijs over het kalenderjaar. Bij granen was er een afname van het volume met $8 \%$ en hogere prijzen (+9\%). De suikerbieten realiseerden net als in 2019 een iets hogere prijs $(+1,5 \%)$, maar de productie daalde in 2020 met zo'n 5\%.

De productiewaarde van de totale tuinbouw is in 2020 gestegen tot meer dan 11,2 mld. euro. De sierteeltsector laat een gemengd beeld zien. In het begin van de Covid-19-crisis werden in ons omringende landen strenge maatregelen doorgevoerd, met als gevolg dat er geen vraag meer was naar bloemen. Hierdoor nam het aanbod op de klokken sterk toe, wat uiteindelijk leidde tot een grote doordraai. Door een vrij sterk herstel van de vraag in de zomer, bleef de productiewaarde voor bloemen uiteindelijk stabiel met gemiddeld ruim 5,5\% hogere prijzen en 5,5\% lagere volumes. Bij planten en boomkwekerijproducten zien we een vergelijkbaar beeld. Bij verse groenten nam de totale productiewaarde met $2 \%$ toe. Net als in 2019 was er in 2020 een hoger aanbod (+3,5\%). De gemiddelde prijs, die in 2019 nog fors steeg, komt in 2020 $1 \%$ lager uit. Met name voor tomaat $(-12 \%)$ waren er lagere prijzen.

De productiecijfers voor fruit, met name appelen en peren, laten in 2020 een daling (-4\%) zien. Wel worden er, ten opzichte van de zeer lage prijzen van 2019, voor 2020 wel fors hogere prijzen $(+33,5 \%)$ gerealiseerd.

De productiewaarde van de totale veehouderij is in 2020, ten opzichte van 2019, gedaald tot onder de 11 mld. euro. Ongeveer de helft hiervan is toe te schrijven aan de rundveehouderij (inclusief melk) en de andere helft aan de intensieve veehouderij. De afname in 2020 wordt vooral veroorzaakt door lagere gemiddelde prijzen in zowel de rundveehouderij (-6\%) als de intensieve veehouderij $(-6,5 \%)$. Het aanbod van melk steeg in 2020 nog wel licht, maar de gemiddelde melkprijs daalde met $4 \%$. Het aanbod van rundvee voor de slacht steeg met bijna 7\%, maar ook hier waren er, voor het tweede opeenvolgende jaar, lagere prijzen $(-10 \%)$. Ook voor varkens zijn in 2020 lagere prijzen $(-8,5 \%)$ gerealiseerd. Dit is het gevolg van een afgenomen vraag naar varkensvlees uit China als gevolg van de Covid-19-crisis en een gedaalde afzet van biggen als gevolg van de uitbraak van Afrikaanse varkenspest in Duitsland. In 2020 komt de eierproductie, net als in 2019,4\% lager uit. De eierprijs bleef wel stabiel. De productiewaarde van vleespluimvee kwam, onder invloed van dalende volumes en iets lagere prijzen, ruim 6,5\% lager uit. Voor de overige agrarische opbrengsten, waarvan de agrarische dienstverlening het belangrijkste onderdeel is, zijn er in 2020 iets hogere volumes en gemiddeld nagenoeg gelijkblijvende prijzen gerealiseerd. Met name de lage verkoopprijs van opgewekte elektriciteit droeg hieraan bij.

\section{Aangekochte goederen en diensten 1\% lager}

De totale waarde van aangekochte goederen en diensten daalde in 2020 met circa 1\%. Dit is het resultaat van een lichte daling van zowel het volume als de gemiddelde prijs. Met name zaaizaad en pootgoed, energie, kunstmest en gewasbeschermingsmiddelen zijn in prijs gedaald. Vooral de daling van de gemiddelde energieprijs was fors $(-16 \%)$. De gemiddelde prijs van veevoer vertoonde in 2020 een lichte stijging. Het totale verbruik in volume komt 0,5\% lager uit. Dit komt door een lagere inzet van vrijwel alle productiemiddelen.

De totale kosten voor de agrarische sector zijn in 2020 afgenomen. Net als de vorige twee jaar is de ruilvoet in 2020 opnieuw achteruitgegaan: gemiddeld genomen zijn de opbrengstprijzen harder gedaald dan de 
prijzen van aangekochte goederen en diensten. De productiviteit, gedefinieerd als de verhouding tussen productievolume en verbruik volume, is in 2020 nagenoeg gelijk gebleven. In 2019 was het productievolume van de totale agrarische sector nog gestegen terwijl er minder productiemiddelen werden ingezet. Dit jaar gaat de afname van de inzet van productiemiddelen gelijk op met het lagere productievolume.

Ongeveer een derde deel van de kosten in de landbouw omvat hier niet nader gespecificeerde posten zoals onderhoud van gebouwen en machines en diverse administratieve diensten (accountants, banken, veilingen, telefoon, mestafzet) die aan de agrarische sector geleverd worden. In de prijs van deze diensten is normaal gesproken weinig ontwikkeling te zien. Deze kan soms licht dalen als gevolg van concurrentie, maar volgt vaak de jaarlijkse inflatie. De volumeontwikkeling voor onderhoud gebouwen komt in 2020 wel iets hoger uit.

\section{Bruto toegevoegde waarde $7,5 \%$ omlaag}

De bruto toegevoegde waarde van de agrarische sector is in 2020 met zo'n 7,5\% gedaald tot ongeveer 10,5 mld. euro. Daarbij bleef de productiviteit nagenoeg gelijk, maar de ruilvoet van de agrarische sector verslechterde: de gemiddelde prijs van de intermediaire kosten daalde minder sterk dan de gemiddelde prijs van de opbrengsten.

Het uiteindelijk voor de ondernemers en hun gezinnen resterend inkomen van de land- en tuinbouw in 2020 is becijferd op 2,7 mld. euro, 15,5\% lager dan in 2019. Van de totale productiewaarde van 28 mld. euro resteert minder dan $10 \%$ als inkomen. Het resterend inkomen wordt bepaald door de bruto toegevoegde waarde te verminderen met de afschrijvingen, de betaalde factorkosten (loon, rente, pacht) en het saldo van de niet-productgebonden subsidies en heffingen. De afschrijvingen in de agrarische sector zijn in 2020 nagenoeg gelijk gebleven. Iets hogere prijzen en een iets lager volume liggen hieraan ten grondslag.

In 2020 is een betalingsrecht 259,73 euro waard. Dit is 3,18 euro lager dan vorig jaar, omdat er minder budget is voor de directe betalingen uit het Gemeenschappelijk landbouwbeleid (GLB). De hoogte van de vergroeningspremie in 2020 komt ook lager uit dan in 2019 en komt uit op ongeveer 112 euro per hectare. De overige niet-productgebonden subsidies zijn met zo'n 355 mln. euro gestegen onder invloed van Covid19-compensaties voor de sierteelt en de frietaardappeltelers en de betalingen aan de sector voor NOW-1, NOW-2 en TOGS. ${ }^{42}$ De niet-productgebonden heffingen komen in 2020 hoger uit, vooral door stijgende waterschapslasten.

De betaalde factorkosten worden in 2020 gekenmerkt door hogere kosten voor lonen en lagere voor pacht en rente. Het aantal betaalde arbeidskrachten in de agrarische sector is in 2020 met $2 \%$ gestegen. De uurlonen namen met zo'n 2,5\% toe; door hogere werkgeverslasten en sociale premies namen de totale loonkosten met zo'n $2 \%$ toe. Ondanks een iets hoger bedrag aan leningen in de land- en tuinbouw daalde het bedrag aan betaalde rente met $8,5 \%$ vanwege een verdere daling van het rentepercentage. Ook de ontvangen rente daalde in 2020 opnieuw fors.

Het totaal areaal pacht - inclusief erfpacht en informele ('grijze/zwarte') pacht - is tussen 2008 en 2019 met gemiddeld met $0,7 \%$ per jaar afgenomen, tegen 0,5\% voor het totale areaal cultuurgrond. Voor 2020 wordt uitgegaan van een daling van het pachtareaal van $0,1 \%$, evenveel als de afname van het totaal areaal cultuurgrond. Voor alle pachtvormen samen wordt uitgegaan van een daling van de prijs met $2,4 \%$. Dit is de gewogen verandering (op basis van het areaal) van de prijsdaling van de pacht met prijsregulatie $(-3,6 \%)$ en die van de pacht zonder prijsregulatie $(-1,8 \%)$.

\subsubsection{Sectorresultaten in EU-27}

Het factorinkomen (netto toegevoegde waarde plus subsidies minus belastingen) per arbeidskracht, gecorrigeerd voor inflatie, wordt door Eurostat gehanteerd als de indicator om de inkomensontwikkeling in de EU-lidstaten met elkaar te vergelijken. Dit factorinkomen is hoger dan het eerder genoemde resterend inkomen, omdat het factorinkomen naast het resterend inkomen ook de vergoeding voor betaalde arbeidskrachten, kapitaal (betaalde rente) en grond (betaalde pacht) omvat. Gecorrigeerd voor inflatie is het

\footnotetext{
42 NOW-1 en NOW-2 zijn regelingen voor de tegemoetkoming van loonkosten personeel, voor werkgevers die door de coronacrisis te maken hebben met omzetverlies. DE Beleidsregel tegemoetkoming ondernemers getroffen sectoren Covid-19 (TOGS) betreft een eenmalige tegemoetkoming van 4.000 euro.
} 
factorinkomen per arbeidskracht in de Nederlandse landbouw in 2020 met 6,7\% afgenomen ten opzichte van 2019. Daarmee behoort Nederland tot de tien dalers in de EU-27. Van de grotere EU landen vertoonden Frankrijk $(-7,6 \%)$, Polen $(-9,6 \%)$ en Duitsland $(-15,5 \%)$ een sterkere daling. In Italie $(-4,8 \%)$ was de afname minder groot dan in Nederland, terwijl Spanje $(+12,5 \%)$ een sterke stijging liet zien. De sterkste stijging deed zich voor in Litouwen $(+18,1 \%)$. Gemiddeld genomen nam het factorinkomen in de 27 lidstaten van de EU in 2020 met 4\% af in vergelijking met 2019.

In zeventien van de 27 lidstaten was er in 2020 een stijging van deze indicator. Het betrof, met uitzondering van Spanje, vooral de kleinere lidstaten. In de overige lidstaten daalde de indicator, variërend van $-0,9 \%$ in Luxemburg tot $-47,2 \%$ in Roemenië.

De sterke toename van het factorinkomen per arbeidskracht in zowel Litouwen als Spanje is toe te schrijven aan fors hogere gewasopbrengsten voor granen en oliezaden. In Spanje waren er daarnaast ook hogere opbrengsten bij olijven. Verder realiseerde Spanje zeer hoge prijzen voor citrusfruit bij een lager volume. De zeer sterke daling van het factorinkomen per arbeidskracht in Roemenië is veroorzaakt door zeer lage gewasopbrengsten voor alle gewassen. Daarnaast stegen de gemiddelde inputprijzen ook nog harder dan de gemiddelde outputprijzen.

In de ons omringende landen (België en Duitsland) deden zich vergelijkbare ontwikkelingen voor als in Nederland. Zowel België als Duitsland laten een afname van het factorinkomen zien met respectievelijk 5,8\% en $15,5 \%$. In Duitsland en Nederland daalden de gemiddelde outputprijzen sterker dan de inputprijzen. Zo waren er lagere prijzen voor varkens en melk.

In 2020 laten vooral een aantal Zuid-Europese landen (Frankrijk, Italië en Portugal) een daling van het factorinkomen per arbeidskracht zien. Voor de meeste van deze landen komt dit door lagere prijzen voor wijn en/of olijfolie. Prijzen voor citrusfruit waren wel hoger. In enkele lidstaten heeft wijn een belangrijk aandeel in de totale opbrengstwaarde van de plantaardige productie.

Nederland kent, met de in productiewaarde gemeten grote omvang van de glastuinbouwsector (groenten, planten en bloemen), een soortgelijke uitzonderingspositie als bij wijn in de Zuid-Europese lidstaten. In 2020 zijn er voor Nederland gemiddeld genomen iets lagere volumes en iets hogere prijzen voor de glastuinbouwproducten. Ondanks dit dempende effect van de glastuinbouw kwam de totale plantaardige productiewaarde voor Nederland in 2020 zo'n 300 mln. euro lager uit dan in 2019. Het intermediair verbruik van productiemiddelen bleef in vrijwel alle landen stabiel, maar in de meeste lidstaten werden gemiddeld wel lagere prijzen voor productiemiddelen betaald. Met name de prijzen van energie gingen omlaag.

\section{Volume agrarische productie}

In de EU-27 is het volume van de totale agrarische productie met $1,3 \%$ afgenomen. De plantaardige productie daalde $(-2,2 \%)$, terwijl de dierlijke productie licht steeg $(+0,6 \%)$. De afname van de productie in de akkerbouw- en tuinbouwsector deed zich in de EU-27 in 2020 voor bij vrijwel alle belangrijke productgroepen, met uitzondering van druiven $(+1,5 \%)$ en olijven $(+19 \%)$. De productie van olijven herstelde daarmee van de zeer forse daling in 2019. Voor suikerbieten en vers fruit is nu voor het tweede jaar op rij sprake van een daling. Als gevolg van de lagere productie werden in 2020 wel gemiddeld iets hogere prijzen dan in 2019 genoteerd. Hoewel er in 2020 zo'n 24\% minder olijfolie werd geproduceerd daalde de prijs voor het derde opeenvolgende jaar fors $(-11,5 \%)$. Ook voor aardappelen, druiven, olijven en wijn werden er in 2020 gemiddeld voor EU-27 lagere prijzen betaald. Deze werden echter gecompenseerd door gemiddeld hogere prijzen voor de meeste andere plantaardige producten zoals granen $(+2 \%)$, bloemen en planten $(+4,5 \%)$ en fruit $(+12 \%)$.

De dierlijke productie in EU-27 steeg licht $(+0,6 \%)$, maar de prijzen daalden met gemiddeld $1,8 \%$. In de veehouderij werd er voor het vierde opeenvolgende jaar meer melk geproduceerd. De productie van eieren daalde iets, na drie opeenvolgende jaren van stijging. Ook bij varkens, zo'n 25\% van de totale dierlijke productie, was er een toename van de productie $(+2 \%)$, maar daalden de prijzen met hetzelfde percentage. Voor melk en pluimvee werden ook lagere prijzen gerealiseerd. Deze twee producten dragen samen voor bijna $50 \%$ bij aan de totale dierlijke productie in de EU-27. 
De hoeveelheid aangekochte goederen en diensten bleef in 2020 stabiel terwijl de prijzen gemiddeld met $0,2 \%$ daalden. De prijzen voor energie en kunstmest daalden met respectievelijk $6,8 \%$ en $2,4 \%$. Zaaizaad en pootgoed $(+2,8 \%)$ en onderhoud gebouwen en machines $(+2,5 \%)$ werden in 2020 duurder. Doordat het volume van de output daalde en het volume van de kosten stabiel bleef nam de productiviteit af. Ook de ruilvoet verslechterde iets doordat de gemiddelde kostprijs minder sterk daalde dan de gemiddelde opbrengstprijs.

De bruto toegevoegde waarde van de landbouw in de totale EU-27 is door deze ontwikkelingen met ruim $3,5 \%$ afgenomen. Hogere afschrijvingen en gelijkblijvende belastingen en licht dalende subsidies leidden tot een daling van het gemiddelde factorinkomen in EU-27 met zo'n 5\%. Het factorinkomen per arbeidskracht in EU-27, gecorrigeerd voor inflatie, daalt met 4\%, dankzij een kleiner arbeidsvolume (-2,9\%).

Verder lezen

Voor de melkveehouderij en de akkerbouw is een uitgebreidere vergelijking van de inkomensontwikkeling in een aantal andere EU-landen beschikbaar op agrimatie. ${ }^{43}$

\subsubsection{Inkomensvorming op bedrijfsniveau}

De resultaten van land- en tuinbouwbedrijven in deze paragraaf en paragraaf 4.6.4 zijn gebaseerd op de gegevens van steekproefbedrijven uit het Informatienet. De resultaten voor 2020 opgesteld in december 2020 zijn echter nog ramingen, die zijn gebaseerd op informatie over ontwikkelingen van prijzen, productiehoeveelheden en dergelijke. De gerepresenteerde steekproefpopulatie bestond in 2020 uit ongeveer 43.250 bedrijven; de overige ongeveer 10.000 door de Landbouwtelling geregistreerde bedrijven zijn kleiner dan de ondergrens van 25.000 euro Standaardopbrengst die voor het Informatienet wordt gehanteerd. Het inkomensbegrip in de berekening van de sectorresultaten (zie paragraaf 4.6.2) wijkt iets af de gepresenteerde resultaten volgens het Informatienet. In het Informatienet vindt de waardering van een aantal plantaardige producten (zoals aardappelen, uien, aardappel, peren, wintergroenten (bijv. spruiten en sluitkool) en lelies) tegen oogstjaarprijzen plaats in plaats van kalenderjaarprijzen zoals gebruikelijk bij de sectorresultaten.

\section{Inkomensvorming}

In 2020, een jaar dat in het teken stond van de coronapandemie, kwam volgens de raming het inkomen uit bedrijf van het gemiddelde land- en tuinbouwbedrijf uit op 78.000 euro (tabel 4.8). Dat is een daling van circa 25.000 euro ten opzichte van het goede landbouwjaar 2019, ondanks coronasteunmaatregelen van de overheid. Het inkomen is vergelijkbaar met de jaren 2016 en 2018 en gemiddeld 20.000 euro hoger dan het gemiddelde in 2011-2015 en 8.000 euro onder het gemiddelde van 2015-2019 (zie tabel 4.8). De gemiddelde opbrengsten per bedrijf voor de totale land- en tuinbouw namen in 2020 met $2 \%$ af tot 601.000 euro, voornamelijk door vraaguitval als gevolg van de coronapandemie. De betaalde kosten en afschrijvingen stegen in 2020 met gemiddeld 3\% naar 522.000 euro, vooral door groei van de bedrijfsomvang.

\footnotetext{
${ }^{43}$ https://www.agrimatie. nl/ThemaResultaat. aspx?subpubID $=2232 \&$ themaID $=2272$ \&indicatorID $=7774$
} 
Tabel 4.8 Resultaat en inkomen (1.000 euro per bedrijf per jaar) van het gemiddelde land- en tuinbouwbedrijf, 2011-2020

\begin{tabular}{|c|c|c|c|c|c|c|c|c|}
\hline & & & 2011-2015 & 2016 & 2017 & 2018 & 2019 & $2020(r)$ \\
\hline \multicolumn{2}{|c|}{ Opbrengsten } & $(+)$ & 530,1 & 540,5 & 590,8 & 590,6 & 611,4 & 601,2 \\
\hline \multirow[t]{3}{*}{ w.v. } & landbouwproductie (\%) & & 91,7 & 92,5 & 93,9 & 93,7 & 94,3 & 94,3 \\
\hline & toeslagen en subsidies (\%) & & 3,9 & 3,7 & 3,4 & 3,3 & 3,0 & 3,1 \\
\hline & overige (onder andere verbi & & 4,4 & 3,9 & 2,8 & 3,1 & 2,7 & 2,6 \\
\hline \multicolumn{2}{|c|}{ Betaalde kosten en afschrijvingen } & $(-)$ & 472,4 & 466,3 & 489,0 & 511,7 & 506,7 & 522,5 \\
\hline \multicolumn{2}{|c|}{ Buitengewone baten en lasten } & $(+)$ & 3,1 & 1,6 & 1,5 & $-0,2$ & $-0,4$ & $-0,4$ \\
\hline \multicolumn{2}{|c|}{ Inkomen uit bedrijf } & $(=)$ & 58,3 & 75,8 & 103,3 & 78,8 & 104,3 & 78,3 \\
\hline \multicolumn{2}{|c|}{ idem per onbetaalde aje } & & 40,4 & 53,3 & 71,1 & 53,1 & 72,9 & 54,4 \\
\hline \multicolumn{2}{|c|}{ Inkomsten buiten bedrijf } & $(+)$ & 18,8 & 16,5 & 13,7 & 11,1 & 16,1 & 14,4 \\
\hline \multirow[t]{2}{*}{ w.v. } & Arbeid & & 9,0 & 7,6 & 7,4 & 8,0 & 8,9 & 8,0 \\
\hline & Overig & & 9,9 & 8,9 & 6,3 & 3,1 & 7,2 & 6,4 \\
\hline \multicolumn{2}{|c|}{ Totaal inkomen } & $(=)$ & 77,2 & 92,3 & 117,0 & 89,9 & 120,4 & 92,7 \\
\hline
\end{tabular}

(r) = raming; overige opbrengsten met ingang van 2013 nieuwe definitie: energiehandel; recreatie; natuurbeheer; energieverkoop; zorg, werk voor derden en zuivelproducten.

Bron: Bedrijveninformatienet Wageningen Economic Research.

Tussen, en ook binnen, de bedrijfstypen in de land- en tuinbouw zijn de inkomensverschillen ieder jaar groot (zie agrimatie voor een andere analyse van de inkomensontwikkeling per type bedrijf). ${ }^{44}$

Het inkomen uit bedrijf wordt vooral bepaald door het saldo van de opbrengsten van land- en tuinbouwproducten en de aan die productie verbonden kosten. Een deel van de opbrengsten, de laatste jaren gemiddeld circa 6\%, komt uit de opbrengsten van niet-agrarische activiteiten en subsidies (tabel 4.8). Bij de ontvangen subsidies gaat het vooral om ontvangen bedrijfstoeslagen (betalingsrechten) van het GLB, deze dragen in belangrijke mate direct bij aan het inkomen. Dit geldt in mindere mate voor de opbrengsten uit niet-agrarische activiteiten, waar de bijbehorende kosten nog op in mindering gebracht moeten worden. Gemiddeld per bedrijf bedragen de opbrengsten uit toeslagen en subsidies de laatste jaren circa 19.000 euro. In de periode 2011-2015 was het aandeel met bijna 4\% nog wat hoger en ook het daarbij behorende bedrag. Dat geldt ook voor de opbrengsten uit onder andere verbredingsactiviteiten. Een mogelijke verklaring voor deze afname is de wijziging in de opname van bedrijven in de Landbouwtelling vanaf 2016. Tot 2015 hoefden onder meer landbouwers zich niet in te schrijven in het Handelsregister (Kamer van Koophandel). Deze inschrijving is echter sinds 2015 als voorwaarde gesteld om in aanmerking te komen voor steun in het kader van het Gemeenschappelijk Landbouwbeleid. Het zijn in het algemeen bedrijven met een kleine agrarische omvang die uit de registratie zijn weggevallen (zie ook bijdrage over verbreding).

Ook kunnen er nog inkomsten zijn van buiten het bedrijf, waaronder uit arbeid, spaargelden, beleggingen en uitkeringen. De inkomsten van buiten het bedrijf fluctueren de laatste jaren gemiddeld rond de 15.000 euro, waarvan 8.000 euro uit arbeid. Ook hier geldt dat de verschillen tussen bedrijven groot zijn. Over de periode 2015-2019 droegen de inkomsten van buiten bedrijf circa 15\% bij aan het totaal inkomen (zie tabel 4.8). Uit een uitgevoerde analyse in het Landbouw-Economisch Bericht van 2015 blijkt dat ondernemers en/of partners op kleinere bedrijven gemiddeld meer buiten het bedrijf werkzaam zijn dan de agrariërs met een groter bedrijf. Naast de bedrijfsomvang speelt ook het bedrijfstype een rol bij het niveau van de inkomsten uit arbeid buiten het bedrijf. Het arbeidspatroon op tuinbouw- en melkveebedrijven laat zich moeilijker verenigen met een werkkring buiten het bedrijf dan op akkerbouw- of intensieve veehouderijbedrijven. In de glastuinbouw en de melkveehouderij komen dan ook vrij veel bedrijven voor zonder, dan wel met zeer lage inkomsten uit arbeid van buiten het bedrijf (Berkhout et al., 2015). Dit beeld wordt bevestigd met de gemiddelde cijfers over 2015-2019 uit tabel 4.7 waarin de akkerbouwbedrijven en intensieve veehouderijtakken (varkens en leghennen) de hoogste inkomsten van buiten bedrijf behalen.

${ }^{44}$ https://www.agrimatie.nl/PublicatiePage.aspx?subpubID $=2291$ \&themaID $=2272 \&$ sectorID $=2243$ 


\section{Inkomensspreiding}

De hoogte van het inkomen van een bedrijf hangt onder andere samen met de marktstrategie, de bedrijfsomvang, de bedrijfsopzet, het productenpakket en de prijsvorming van die producten. Uiteraard spelen bij al die punten ook vakmanschap en managementkwaliteiten van de ondernemers een rol. Bij de schommelingen van het inkomen door de jaren speelt vooral de prijsvorming van de producten een grote rol en daarnaast in de open teelten de variatie in kg-opbrengsten, die onder invloed van het weer van jaar tot jaar sterk kunnen wisselen. In 2020 heeft de uitbraak van corona in diverse sectoren gezorgd voor een minder continue productiestroom als gevolg van vraaguitval, wat leidde tot leegstand van stallen bij vleeskuikens en kalveren en het minder oppotten van nieuwe planten in kassen.

Om de bedrijfsresultaten van in omvang verschillende bedrijven beter te kunnen vergelijken, wordt het inkomen veelal uitgedrukt in euro per onbetaalde arbeidsjaareenheid (aje). Daarmee is de vergoeding, het inkomen, dus gekoppeld aan de input van arbeid waar het een vergoeding voor is. Agrarisch ondernemers en hun gezinsleden verrichten in de meeste sectoren nog de meeste arbeid zelf, maar krijgen meestal geen salaris. Een arbeidskracht die in een jaar 2.000 uur of meer werkt, wordt gezien als een aje. Wie minder werkt, is minder dan één aje. Gemiddeld zijn er per bedrijf 1,5 onbetaalde aje; dit aantal is door de jaren heen vrij constant. Het gaat hier om de ondernemers, hun partners en andere niet-betaalde gezinsleden.

Voor 2020 is voor land- en tuinbouwbedrijven een gemiddeld inkomen geraamd van 54.400 euro per onbetaalde aje (zie onderstaande figuur 4.12). In de figuur geeft het groene vlak de inkomens per onbetaalde aje van $60 \%$ van de bedrijven weer. Deze bandbreedte loopt van 4.000 euro negatief tot 78.000 euro. $20 \%$ van de bedrijven realiseert een inkomen dat nog lager is dan 4.000 euro negatief, een even grote groep behaalt een inkomen dat hoger is dan 78.000 euro In 2020 bevinden de glastuinbouw-, geiten-, vollegrondsgroente-, boomkwekerij- en bloembollenbedrijven zich vooral aan de bovenkant van de inkomensverdeling en de varkens-, biologische melkveebedrijven en bedrijven met reguliere vleeskuikens aan de onderkant (www.agrimatie.nl). Binnen een bedrijfstype geldt voor veel bedrijven dat ze min of meer een relatief vaste positie ten opzichte van anderen hebben. Goed ondernemerschap zorgt ervoor dat de besten vaak de besten blijven. Door jaarlijks wisselende inkomens per bedrijfstype kan de samenstelling van de groep met hoge en lage inkomens van jaar tot jaar verschillen. Meest in het oog springende sector de laatste jaren is de varkenshouderij met als gevolg van de varkenscyclus afwisselende jaren met hoge en lage inkomens (zie ook bijdrage lage inkomensproblematiek). De laatste 10 jaar is de bandbreedte waarin het inkomen van $60 \%$ van de bedrijven ligt (groene vlak in figuur 4.12) ongeveer 75.000 euro. In de twee jaren met de hoogste gemiddelde inkomens, 2017 en 2019, is de bandbreedte wat groter. Het gegeven dat het gemiddelde inkomen per onbetaalde aje de laatste jaren hoger in het groene vlak ligt maakt duidelijk dat er een beperkte groep agrarische bedrijven met jaarlijks hoge inkomens is, die het gemiddelde van de gehele sector omhoog halen. Op www.agrimatie.nl zijn voor de afzonderlijke bedrijfstypen in de land- en tuinbouw spreidingsfiguren van het inkomen beschikbaar. 


\section{Ontwikkeling en spreiding van inkomen uit bedrijf per onbetaalde aje}

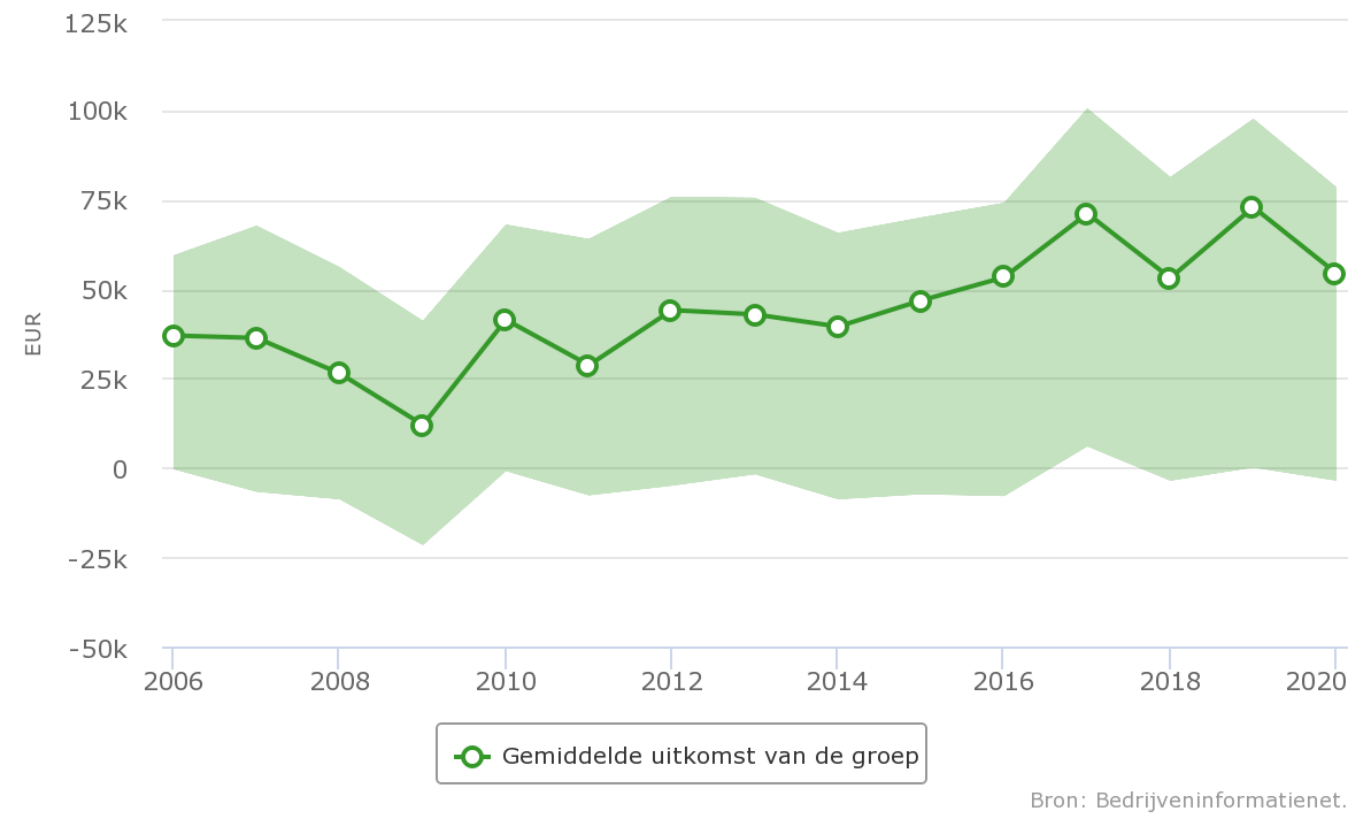

Figuur 4.12 Ontwikkeling en spreiding van inkomen uit bedrijf per onbetaalde aje

\subsubsection{Bedrijven met lage inkomens}

Het gemiddelde inkomen in de land- en tuinbouw steeg in 2019 naar ongeveer 107.000 euro per huishouden, het hoogste niveau in deze eeuw. In samenhang daarmee daalde het aandeel huishoudens onder de lage inkomensgrens van 26.300 euro van $39 \%$ in 2018 tot $35 \%{ }^{45}$ (figuur 4.13). Vooral onder akkerbouwbedrijven was in 2019 het aandeel met een inkomen onder de lage inkomensgrens bovengemiddeld als gevolg van lagere aardappelprijzen. De afgelopen jaren lag het aandeel huishoudens onder de lage inkomensgrens vaak boven de $30 \%$. Voor het bepalen van de hoogte van het inkomen van de huishoudens wordt het totaal inkomen gebruikt. Dat bevat zowel het inkomen uit bedrijf als de inkomsten van buiten bet bedrijf. Het vermogen van een huishouden wordt buiten beschouwing gelaten. Een gemiddeld land- en tuinbouwbedrijf bestaat uit 1,12 huishoudens.

\footnotetext{
${ }^{45}$ De lage inkomensgrens is gebaseerd op de hoogte van de IOAZ-uitkering (Wet Inkomensvoorziening oudere en gedeeltelijk arbeidsongeschikte gewezen zelfstandigen) en wordt jaarlijks gecorrigeerd voor de prijsontwikkeling.
} 


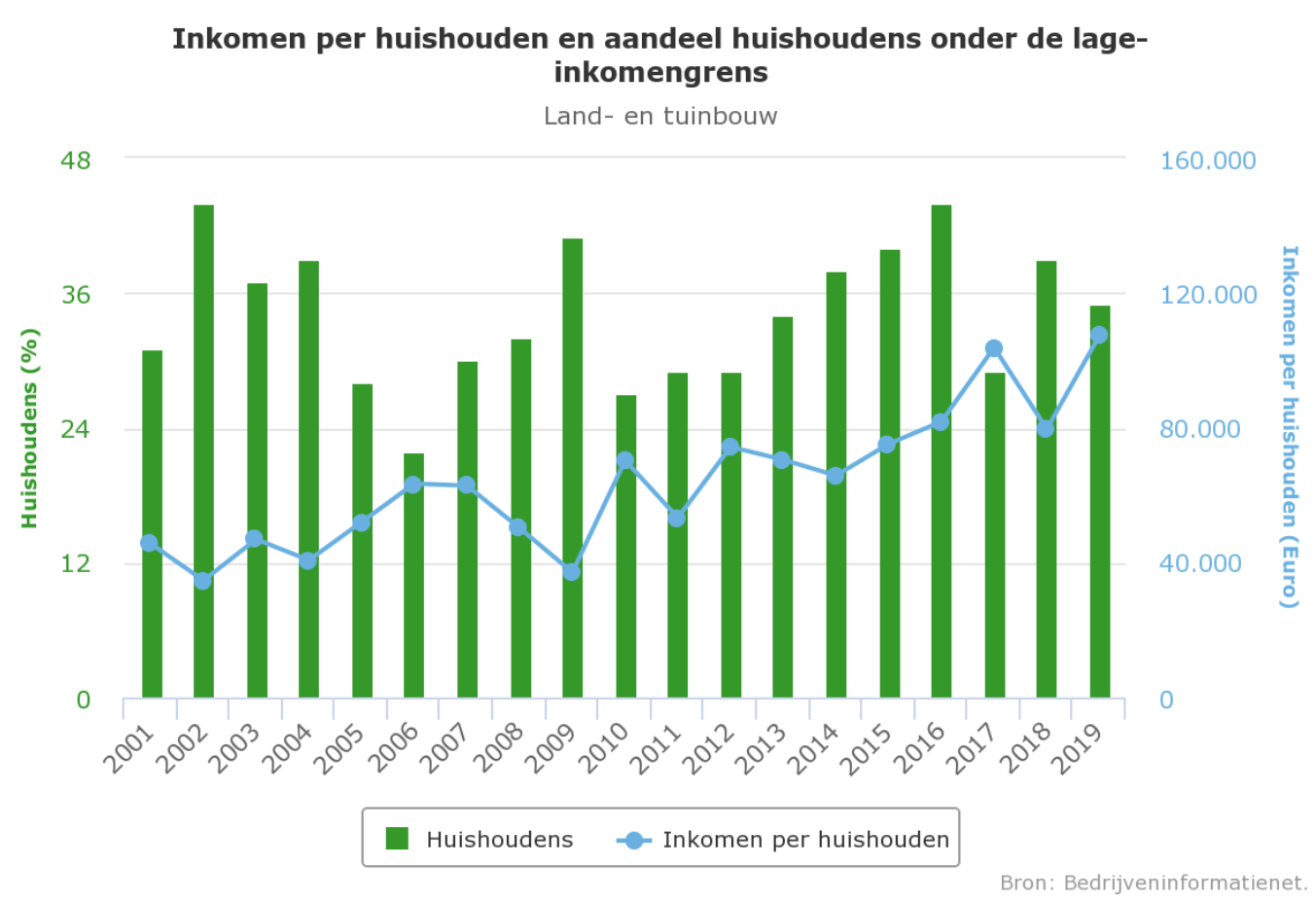

Figuur 4.13 Inkomen per huishouden en aandeel huishoudens onder de lage-inkomensgrens, 2001-2019 Bron: Bedrijveninformatienet.

Er zijn grote verschillen in het aandeel huishoudens onder de lage inkomensgrens, zowel tussen bedrijfstypen als tussen bedrijfsgroottes. In 2019 was van de grote sectoren in de land- en tuinbouw de akkerbouw de sector met het hoogste aandeel huishoudens onder de lage inkomensgrens (45\%) (zie figuur 4.14). Dit werd veroorzaakt door matige inkomens als gevolg van lagere opbrengstprijzen van een aantal producten zoals aardappelen en uien. Dit zijn gewassen met een groot aandeel in het bouwplan, waarvan de prijzen jaarlijks flink kunnen fluctueren; dit werkt hard door in het inkomen. De lage opbrengstprijzen van aardappelen waren mede het gevolg van de uitbraak van Covid-19 in het voorjaar van 2020. Het verkoopseizoen 2019/2020 eindigde met zeer lage prijzen voor vrije consumptieaardappelen, vooral het gevolg van het wegvallen van fritesafzet naar de horeca en van exportmogelijkheden door de coronamaatregelen.

In de periode 2015-2019 is het aandeel huishoudens onder de lage inkomensgrens gemiddeld het kleinst in de glastuinbouw dankzij de goede bedrijfsresultaten in die jaren in zowel de glasgroente- als sierteelt. Bij de varkensbedrijven schommelt het aandeel van de groep met lage inkomens tussen de jaren behoorlijk, als gevolg van de varkenscyclus. In 2015 en 2018 lag het gemiddelde inkomen per huishouden onder en licht boven nul euro als gevolg van erg lage opbrengsten. Deze slechte jaren werden gevolgd door jaren met bovengemiddelde inkomens als gevolg van wereldwijde uitbraak van Afrikaanse varkenspest, vooral in OostAzië. Hierdoor viel de productie van varkensvlees daar weg en kon Nederland als exporterend land het ontstane tekort aan varkensvlees aanvullen.

Voor de in aantallen bedrijven grootste sector, de melkveehouderij, waren 2015 en 2016 jaren met lage melkprijzen en daardoor een bovengemiddeld aantal melkveebedrijven onder de lage inkomensgrens. In 2017 is door een sterk herstel van melkprijzen wel weer wat lucht ontstaan. Het jaar 2017 werd gevolgd door een tweetal jaren met voor de sector gemiddelde inkomens. 
80

60

20

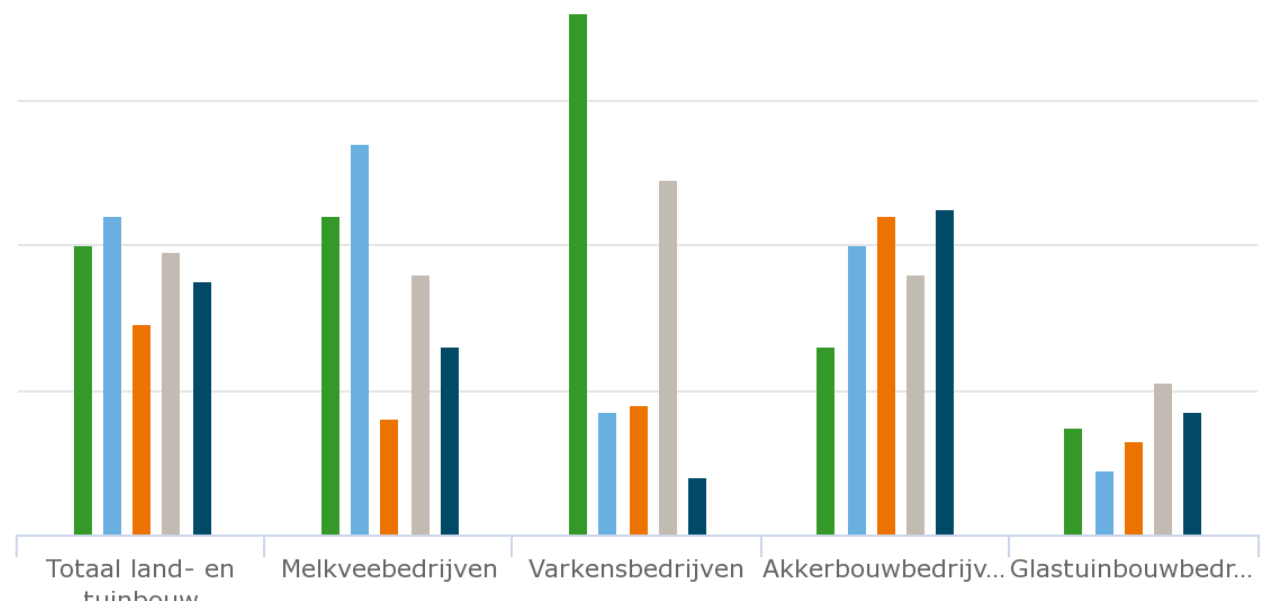
tuinbouw

$$
2015 \square 2016 \square 2017 \square 2018 \square 2019
$$

Figuur 4.14 Aandeel huishoudens onder de lage-inkomensgrens naar sector, 2015-2019 Bron: Bedrijveninformatienet.

Van de huishoudens in de groep kleinste bedrijven ( $<100.000$ euro SO) blijft $63 \%$ onder de lage inkomensgrens in 2019. Met name overige akkerbouw- en rundveebedrijven maken deel uit van deze groep. In de vier voorgaande jaren lag het percentage in deze groep kleinste bedrijven ook telkens boven de $50 \%$ (zie figuur 4.15). Ondanks de gemiddeld grotere bijdrage van het inkomen buiten bedrijf aan het totale inkomen is dat in vele gevallen ontoereikend om het inkomensniveau boven de lage inkomensgrens te tillen. Op de grotere bedrijven liggen de aandelen aanzienlijk lager. In 2015 en 2018 is het aandeel huishoudens met een laag inkomen bij de grotere bedrijven relatief fors geweest. Dit is vooral het gevolg van de ontwikkelingen in de varkenshouderij, waar relatief veel grote bedrijven te vinden zijn.

Aandeel huishoudens onder de lage-inkomensgrens, naar bedrijfsgrootte

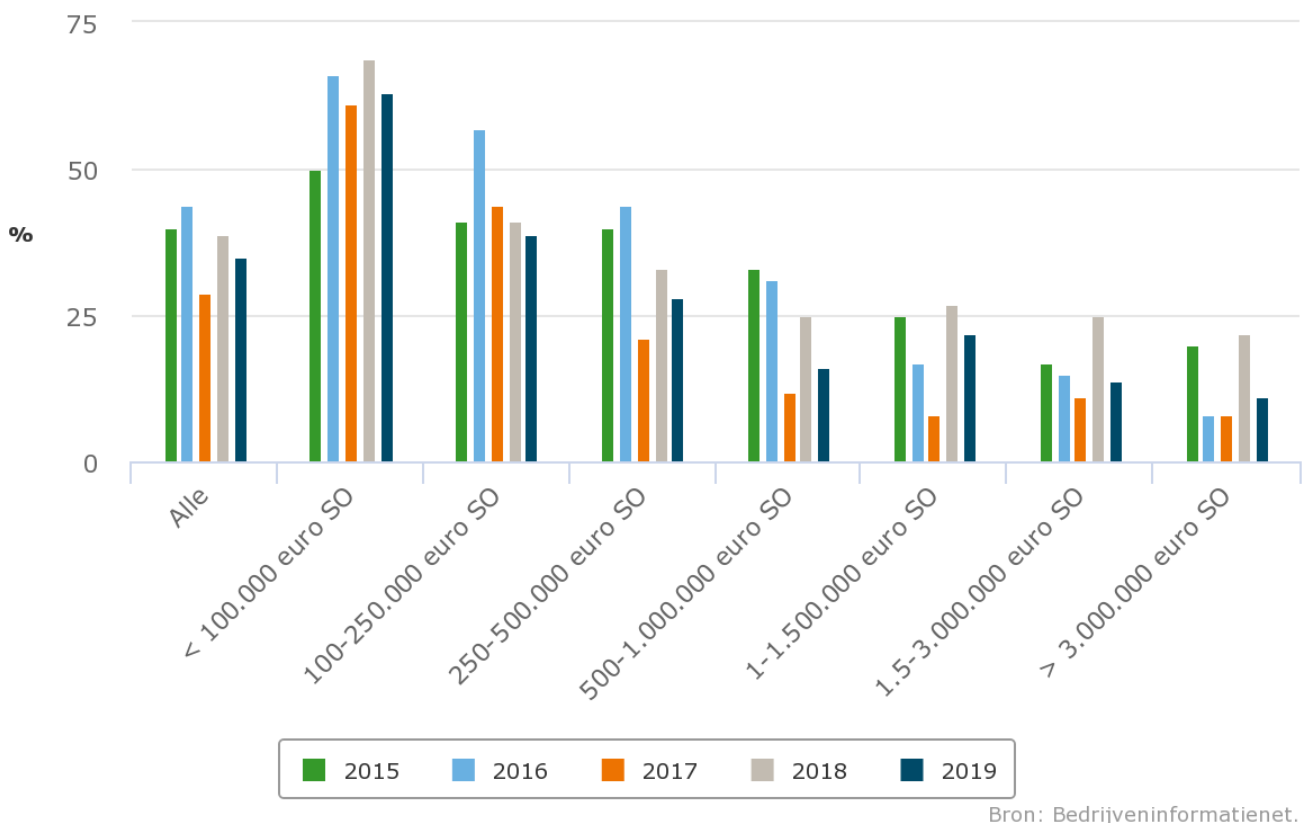

Figuur 4.15 Aandeel huishoudens onder de lage-inkomensgrens naar bedrijfsgrootte in SO, 2015-2019 Bron: Bedrijveninformatienet. 


\subsection{Dilemma's hervorming pachtstelsel}

Al jarenlang wordt gesproken over een hervorming van het pachtstelsel, mede naar aanleiding van de evaluatie van prof. Bruil uit 2014. Landbouwminister Carola Schouten zou begin 2021 met concrete wijzigingsvoorstellen komen. Aan het eind van 2020 hebben daartoe nog gesprekken plaats gevonden tussen het ministerie van LNV en belanghebbende partijen. De visies van deze partijen staan lijnrecht tegenover elkaar. De FPG, de organisatie van landeigenaren, noemt het huidige stelsel failliet en wil vrijheid voor verpachters om met pachters afspraken te maken over prijs, duur en voorwaarden van het grondgebruik. Daarentegen wil de organisatie van pachters (BLHB) de huidige bescherming van de pachters behouden en langdurige pachtcontracten bevorderen. Hoe de minister de Gordiaanse knoop zou willen doorhakken is niet openbaar gemaakt. Op 27 januari 2021 verklaarde de Tweede Kamer het pachtbeleid 'controversieel'. De herziening van het pachtstelsel wordt daarmee overgelaten aan het volgende kabinet. Deze bijdrage gaat in op de achtergrond van de problematiek en schetst enkele dilemma's voor het toekomstige beleid.

\section{Pachtmarkt verbonden met koopmarkt}

De pachtmarkt staat niet op zichzelf maar is verbonden met de koopmarkt van landbouwgrond. In Nederland is de koopmarkt van landbouwgrond al sinds het begin van de jaren zestig vrij. Vanaf die tijd is de agrarische grondprijs fors opgelopen, mede door de sterke daling van de rentevoet. Een van andere hoofdfactoren hierbij is de doorgaande bedrijfsvergroting, die mogelijk is gemaakt door de technologische ontwikkeling. De agrarische grondprijs is hierdoor meer een afspiegeling van de marginale waarde voor de koper dan een indicator voor de gemiddelde verdiencapaciteit van de grond. Dit levert een spanning op met de gereguleerde pachtprijs, die wel op deze verdiencapaciteit gebaseerd is.

De regulering door de overheid heeft sommige problemen van de pachtmarkt opgelost maar andere in de hand gewerkt. Het huidige stelsel is gemengd. Aan de ene kant is er de reguliere pacht die voorziet in een sterke bescherming van de pachter (vooral het continuatierecht, de automatische verlenging van de wettelijke looptijd van de pachtovereenkomst) en in hoogst toelaatbare pachtprijzen (zie kader). Aan de andere kant is er voor los land de geliberaliseerde pacht, waarvoor nauwelijks wettelijke bepalingen gelden en waarbij de pachtprijs vrij is. Alleen bij een pachtduur langer dan 6 jaar wordt de pachtprijs getoetst aan de pachtnormen. En dan is er nog het grote areaal dat op informele wijze (grijze en zwarte pacht) in gebruik is (zie Landbouwareaal naar grondgebruikstitels op agrimatie. $\mathrm{nl}$ ).

\section{Hoogst toelaatbare pachtprijzen}

Jaarlijks stelt de minister van LNV zogenaamde pachtnormen vast. De normen voor los land zijn van toepassing op reguliere pacht en op geliberaliseerde pacht langer dan zes jaar.

De pachtnormen werden oorspronkelijk ingevoerd met de Pachtwet van 1958 en vanaf 1967 vastgelegd in het 'Pachtnormenbesluit'.

Tot 1992 waren de pachtnormen voor bouw- en grasland gebaseerd op grondsoort, waarbij onderscheid gemaakt werd in drie kwaliteitsklassen. In het Pachtnormenbesluit 1995 werden de pachtnormen niet meer gebaseerd op de grondsoort maar op de vrije verkeerswaarde van de grond in een regio. Op termijn zou de pachtprijs op $2 \%$ van de vrije verkeerswaarde moeten komen om pacht als financieringsvorm voor de landbouw aantrekkelijker te maken voor met name de verpachter. Maar toen de prijs van landbouwgronden in de tweede helft van de jaren negentig alsmaar bleef stijgen, kwam het einddoel, pachtprijzen gelijk aan $2 \%$ van de vrije verkeerswaarde van landbouwgrond, steeds verder weg te liggen. Een tweede aanleiding voor de $2 \%$-systematiek was het gegeven dat de gereguleerde pachtprijzen in de diverse landbouwgebieden weinig samenhang vertoonden met de grondprijzen in die gebieden.

Op 1 september 2007 werd de Pachtwet ingetrokken en vervangen door het pachtrecht in het Burgerlijk Wetboek (BW titel 7.5). De opname van de wet in het BW houdt in dat de pachtwetgeving meer aansluit bij andere privaatrechtelijke wetgeving. De wet introduceert geliberaliseerde pacht voor los land: tot 6 jaar vrij van pachtnormen; boven 6 jaar met pachtnormen. Daarbij is een nieuwe regeling van de pachtnormen vastgesteld. Gefaciliteerd door de overheid zijn de organisaties van pachters en verpachters samen tot een nieuwe berekeningswijze van de pachtnormen gekomen.

$\mathrm{Na}$ enkele technische aanpassingen worden de pachtnormen tegenwoordig jaarlijks bepaald op basis van een vijfjaargemiddelde van de opbrengst van het land, de grondbeloning, met een correctie voor de rendementseis van verpachter. Hierbij wordt onderscheid gemaakt tussen regio's, de pachtprijsgebieden. Deze komen grotendeels overeen met de 14 groepen van landbouwgebieden (zie Silvis et al., 2021). 
Het gemengde karakter van het pachtstelsel is voortgekomen uit de lange geschiedenis van de regelgeving, waarbij de overheid eerst vooral de pachters heeft willen beschermen. In een later stadium is getracht de nadelige gevolgen hiervan bij te stellen, met inachtneming van de bestaande rechten. Hierdoor is de markt verdeeld. De groep pachters met reguliere overeenkomsten wil hun beschermde positie handhaven, andere marktpartijen willen de vrije markt uitbreiden.

\section{Geen instemming met hervormingsvoorstellen}

In zijn evaluatie van de pachtregelgeving typeerde Bruil het stelsel als tweeslachtig: aan de ene kant is er het reguliere systeem met alle mogelijke bescherming voor de pachters en aan de andere kant een geliberaliseerd systeem voor los land, zonder enige bescherming en hogere kosten voor de pachter. In het algemeen is de huidige reguliere pacht onaantrekkelijk voor verpachters vanwege de sterke bescherming van de pachter. Voor de korte termijn staat de geliberaliseerde pacht ter beschikking, voor de langere termijn de erfpacht. Voor overeenkomsten tussen 6 jaar en 26 jaar is er alleen de onaantrekkelijke pacht met gemaximaliseerde prijzen. Volgens prof. Bruil geeft de korte uitgifte onzekerheid op continuïteit in gebruik. 'Daar komt bij dat bij hoge pachtprijzen agrariërs een hoog rendement uit de grond moeten halen met het risico dat de bodemkwaliteit daalt'. De huidige pachtregelgeving is strijdig met de wensen voor een duurzamer grondgebruik, aldus de evaluator. In zijn rapport stelde hij een regeling voor met zoveel mogelijk autonomie van partijen, en met alleen de meest noodzakelijke dwingendrechtelijke bepalingen. Na de publicatie is er een overlegtraject met de betrokken belangenorganisaties gestart dat, naar de naam van de plaats van samenkomst, het Spelderholt overleg is gaan heten. Het is echter niet gelukt om een akkoord te bereiken waarmee alle partijen instemden: het Eindakkoord van Spelderholt is afgewezen door de BLHB en het NAJK. LTO Nederland heeft in een latere visie (2020) afstand genomen van dit akkoord.

\section{Bevordering van de bodemkwaliteit}

In de zogenoemde bodemstrategie heeft LNV-minister Schouten het streefbeeld verwoord dat in 2030 alle Nederlandse landbouwbodems duurzaam worden beheerd, zodat de bodem optimaal kan functioneren en de kwaliteit zo hoog mogelijk is en blijft voor volgende generaties (Minister van LNV, 2018). De minister beschouwt het pachtstelsel als een van de instrumenten voor het bevorderen van duurzaam bodembeheer. De minister zou tot een vorm van langdurige pacht willen komen, die de nieuwe standaard zou moeten worden. Ook zou er meer vrijheid moeten komen om aanvullende voorwaarden af te spreken voor met name het borgen van de bodemkwaliteit. Het voornemen was om, na afronding van de consultatie, de parlementaire behandeling van de herziening van de pachtwetgeving in 2020 te laten plaatsvinden. Dit is echter niet gelukt en na het vallen van het kabinet Rutte III is het pachtdossier controversieel verklaard. Voorlopig zal dan ook gewerkt moeten worden binnen de kaders van de huidige wet- en regelgeving.

De huidige pachtregelgeving is vooral gericht op bescherming van de (vrijheid van de) pachter. Verpachters kunnen lopende overeenkomsten niet openbreken, anders dan bij wederzijdse instemming van beide partijen. Per type pachtovereenkomst zijn er niettemin verschillende mogelijkheden voor het opnemen van voorwaarden gericht op het borgen van de bodemkwaliteit (Pleijte et al., 2020). De verpachter kan overwegen om in ruil voor aangepast beheer door de pachter een korting op de pachtprijs aan te bieden. Diverse provincies, landgoederen en kerkgemeenschappen vragen aan hun pachters om biologisch te telen, met daarbij een lagere dan gemiddelde pachtprijs. Verpachters kunnen ook beheerovereenkomsten aan pachters aanbieden met afspraken over de grondbewerking en gewassenteelt, zodanig dat de bodemkwaliteit duurzaam wordt geborgd. Hierbij valt te denken aan: Toepassing organische of ruige mest; Verlaging van de bandenspanning (onder 1 bar) en wiellast (onder 3 ton); Voorschrift ten aanzien van rustgewassen; Biologische of mechanische onkruidbestrijding; Actief biologisch randenbeheer. Vooral in combinatie zijn dit maatregelen die de fysieke en de biologische toestand van de bodem kunnen verbeteren. Dit verbeteren zal wel de nodige tijd in beslag nemen, afhankelijk van de uitgangssituatie. Het zal snel meer dan 6 jaar kunnen duren. Bodemverbetering, met een groter waterdoorlatend én -vasthoudend vermogen, een betere weerbaarheid tegen met name bodemgebonden ziekten, een betere structuur et cetera is een zaak van lange adem die niet binnen de veelgebruikte termijn van 6 jaar in de geliberaliseerde pacht te realiseren is (Kik et al., 2021).

\section{Dilemma's voor het beleid}

Voor het te voeren beleid doemt een aantal dilemma's op. Als economische doelen of functies van het pachtstelsel kunnen worden genoemd: grondfinanciering voor landbouw, evenwichtige resultaatverdeling tussen pachter en verpachter, en doelmatig en flexibel grondgebruik. Bij het laatste doel gaat het niet alleen 
om bescherming van de bodemkwaliteit maar ook om een goede mix van vaste en flexibele overeenkomsten, die dienstbaar is aan een concurrerende en innovatieve landbouw. De middelen van de pachtregelgeving zijn echter beperkt: pachtovereenkomsten worden vrijwillig aangegaan; op de afspraken tussen partijen is geen bestuurs- of strafrechtelijke controle door de overheid. Per doel worden hierna enkele aandachtspunten genoemd (Silvis en Voskuilen, 2018).

\section{Pacht als instrument voor grondfinanciering}

- Het reguliere pachtareaal loopt steeds verder terug. Die trend is moeilijk te keren. De bescherming van de pachter met reguliere pacht maakt alternatieven aantrekkelijker voor verpachters. De daling van het reguliere pachtareaal is gecompenseerd door meer kortlopende pacht, zodat het totale aandeel pacht sinds 2007 slechts licht is gedaald. Kortlopende pacht geeft echter minder zekerheid, en maakt het verkrijgen van (bank)leningen voor investeringen lastiger.

- Bij reguliere pacht is praktisch alleen reallocatie van grond mogelijk bij bedrijfsbeëindiging. Het vervallen van de leeftijdgrens van 65 jaar heeft dit probleem versterkt.

- Door organisaties van verpachters en pachters zijn uiteenlopende opties naar voren gebracht om de tweedeling te verzachten: voorwaarden langdurige pacht verlichten versus voorwaarden kortlopende pacht verzwaren. Er is geen consensus over de manier waarop.

\section{Resultaatverdeling tussen pachter en verpachter}

- Via de pachtnormen wordt gestreefd naar een redelijke resultaatverdeling tussen de pachter en de verpachter. Deze normen zijn uitermate belangrijk voor de groep pachtafhankelijke bedrijven maar alleen van toepassing op reguliere pacht en langlopende liberale pacht. Bij de korte geliberaliseerde pachtvorm neigt de resultaatverdeling meer in het voordeel van de verpachter uit te vallen.

- Prijsbepaling door de overheid zal altijd kritiek ontmoeten, omdat de verpachters en pachters op dit punt tegengestelde belangen hebben.

- Er zijn vrij grote jaarlijkse schommelingen in pachtnormen per pachtprijsgebied, ondanks de basis van het voortschrijdend gemiddelde van de grondbeloning en de rendementseis van de verpachter. Merk op dat jaarlijkse schommelingen in het inkomen van de pachter veel groter (kunnen) zijn. Stabilisatie van normen heeft voor- en nadelen. Marktpartijen kunnen ook onderling afspraken maken om de effecten te verzachten door een betalingsregeling te treffen.

\section{Doelmatig en flexibel grondgebruik}

- Als nadeel van de kortlopende pachtvorm geldt dat de bodemkwaliteit in de knel kan komen, vooral in samenhang met de teelt van rooigewassen (aardappelen, suikerbieten, uien en bloembollen). Hoge pachtprijzen kunnen aanleiding vormen om een hoog rendement te willen behalen. Dat leidt tot het telen van gewassen met een hoog saldo, ofwel zogenoemde intensieve gewassen, die veel van de grond vragen, en die (voor een deel) laat in het seizoen worden geoogst. Bij de teelt van deze intensieve gewassen en/of late oogst is het risico op uitputting van de grond respectievelijk op structuurbederf en verdichting groter dan bij meer extensieve gewassen (granen, peulvruchten en handelsgewassen, zoals vlas, hennep en koolzaad). Maaigewassen hebben over het algemeen een betere doorworteling en dragen zo, samen met het bodemleven, bij aan structuurherstel. Verder leveren granen en grasland meer organische stof aan de bodem dan rooigewassen.

- In het algemeen verdient een langlopend pachtcontract de voorkeur boven kortlopende pacht met het oog op duurzaam grondgebruik en bedrijfsontwikkeling (inclusief financiering). Langdurige pacht geeft de pachter zekerheid over voortzetting van het grondgebruik, wat een stimulans is voor investeren in bedrijfsontwikkeling en bodembeheer.

- $\mathrm{Er}$ is ook behoefte aan kortlopende pacht (bij voorbeeld teeltpacht). Kortlopende pacht biedt namelijk kansen voor gedifferentieerd grondgebruik (rotatie) en afstemming van de bodemkwaliteit op de eisen van het gewas (Buurma et al., 2016).

- Voor flexibele pacht als aanvulling op het bedrijfsareaal kan een hogere prijs worden betaald, omdat de marginale waarde hoger is dan de gemiddelde waarde.

- Het pachtstelsel heeft betrekking op een deel van het landbouwareaal. Meer dan de helft is in eigendom en een aanzienlijk deel is niet als pacht geregistreerd. Directe maatregelen (mestbeleid) en indirecte maatregelen (voorwaarden GLB-betalingsrechten) liggen als instrumenten voor verduurzaming grondgebruik meer voor de hand dan pachtregels, al dient gewaakt te worden voor een averechts effect van het pachtbeleid op dit doel. 


\section{$5 \quad$ Overige agribusiness}

\section{$5.1 \quad$ Inleiding}

Dit hoofdstuk behandelt de overige agribusiness. ${ }^{46}$ Paragraaf 5.2 gaat in op de achtergrond van de verschillende thema's. Vervolgens beschrijft paragraaf 5.3 de ontwikkelingen van de bedrijfsaantallen. Daarbij worden onder meer de oprichtingen en opheffingen binnen deze schakels besproken. Ook komen de kenmerken van het personeelsbestand, zoals het geslacht en het gemiddelde uurloon van de werknemers die er werkzaam zijn, aan bod.

Paragraaf 5.4 brengt de innovatie binnen de agribusiness over de periode 2016-2018 in kaart. Het aandeel innovatieve bedrijven, de mate van samenwerking met overheidsinstellingen en universiteiten en de innovatie-uitgaven passeren de revue. Deze worden vergeleken met Nederland als geheel. Paragraaf 5.5 beschrijft de R\&D binnen de agribusiness aan de hand van verschillende indicatoren. Paragraaf 5.6 tenslotte gaat in op investeringen in materiële vaste activa.

Het gedeelte over bedrijvendynamiek en investeringen richt zich op de overige agribusiness en laat de primaire landbouw ${ }^{47}$ buiten beschouwing, daar die al in het vorige hoofdstuk aan bod is gekomen. Bedrijven worden tot de overige agribusiness gerekend indien ze behoren tot een van de volgende sectoren: Vervaardiging van voedingsmiddelen, Vervaardiging van dranken, Vervaardiging machines en chemicaliën, Handelsbemiddeling agribusiness, Groothandel agribusiness, Supermarkten, Voedingswinkels en markthandel, of Rest agribusiness. ${ }^{48}$

\subsection{Achtergrond}

\section{Bedrijvendynamiek}

Naast financiële gegevens, is ook de bedrijvensamenstelling belangrijk in een economie. Deze is altijd aan verandering onderhevig. Nieuwe economische activiteiten worden opgestart, terwijl andere activiteiten worden stilgelegd. Dit staat ook wel bekend als bedrijvendynamiek (Verhoeven, 2005), en die is onder andere afhankelijk van veranderingen in ondernemerschap.

Nieuwe bedrijven die worden opgericht door nieuwe ondernemers (zelfstandig, dan wel als dochteronderneming) zorgen voor werkgelegenheid. Bedrijven die sluiten door bijvoorbeeld een faillissement maken daarentegen plaats voor nieuwe bedrijven. Ook kunnen bedrijven worden overgenomen, afgesplitst of gefuseerd.

\section{$R \& D$}

Om nieuwe kennis en kunde te ontwikkelen, is het van belang te investeren in R\&D. Kenmerkend voor R\&D is dat het onderzoek naar vernieuwing streeft. Volgens de definitie die statistische bureaus internationaal hanteren, betreft R\&D:

'creatief werk dat op systematische basis wordt verricht ter vergroting van de hoeveelheid kennis, met inbegrip van de kennis van de mens, de cultuur en de samenleving, alsmede het gebruik van deze hoeveelheid kennis voor het ontwerpen van nieuwe toepassingen' (OESO, 2015).

\footnotetext{
${ }^{46}$ Zie bijlage 3 voor een definitie van gehele agribusiness.

47 Tot de primaire landbouw rekenen we volgende sectoren: Teelt van eenjarige gewassen, Teelt van meerjarige gewassen, Teelt van sierplanten, Veeteelt en fokkerijen, Gemengd bedrijf, Dienstverlening voor de landbouw, Jacht, Visserij, en Viskwekerij.

${ }^{48}$ Tot deze restcategorie behoren de volgende subsectoren: Keuring en controle van agrarische producten en voedingsmiddelen, Biotechnologisch speur- en ontwikkelingswerk op het gebied van agrarische producten en processen, Speur- en ontwikkelingswerk op het gebied van landbouw en visserij (niet biotechnologisch), Verhuur en lease van landbouwmachines en -werktuigen, Veilingen van landbouw-, tuinbouw- en visserijproducten.
} 
Traditioneel gaat R\&D over fundamenteel en toegepast onderzoek naar nieuwe kennis en technologie. Later monden deze kennis en technologie mogelijk uit in concrete nieuwe producten en processen.

R\&D wordt in Nederland voor het grootste deel uitgevoerd binnen de bedrijvensector (CBS, 2020a). Daarbinnen vinden structureel de meeste R\&D-uitgaven plaats in de industrie. De dienstverlening neemt structureel het grootste deel van de gespendeerde arbeidsjaren aan R\&D voor haar rekening. Dit komt vooral omdat R\&D binnen de industrie duurder is en technischer van aard dan binnen de dienstverlenende sector.

Innovatie bij landbouw gerelateerde sectoren

Innovaties in de agribusiness zijn er vaak op gericht de productie te optimaliseren, maar ook steeds meer om duurzaam te produceren. De Wereldbank suggereert zelfs dat agriculturele innovaties een sleutelrol spelen bij het bestrijden van armoede in ontwikkelingslanden. Dit zou bewerkstelligd worden door onder andere opbrengstverhoging en het efficiënter inzetten van inputs, maar ook door het aanpassen aan klimaatsverandering en productverbetering (Keith, 2020).

Er zijn talloze voorbeelden van innovatieve producten in de agribusiness die inzetten op de genoemde doelstellingen. Bijvoorbeeld betere meststoffen om planten en bloemen sneller te laten groeien, worden ingezet omwille van opbrengstverhoging en efficiënter gebruik van tijd. Productverbetering betreft onder andere voedingsingrediënten die bevordelijk zijn voor de gezondheid. Dit zijn bijvoorbeeld probiotica, cholesterolverlagende producten en gluten- en lactosevrije producten.

\section{Belang R\&D en innovatie}

$R \& D$ in de agribusiness is wereldwijd een middel om armoede en honger te bestrijden. Uitgaven in R\&D hebben namelijk geleid tot een toename van de voedselproductie en een afname van de voedselprijs (Alston, 2010). De literatuur op het gebied van de economie van landbouwgerelateerde R\&D is breed ontwikkeld. Uit deze studies valt te concluderen dat de wereld evenals individuele landen flink hebben geprofiteerd van productiviteitsgroei in de landbouw en daaraan verwante sectoren. Deze groei is voor een groot deel een gevolg van technologische veranderingen door publieke en private investeringen in landbouw R\&D. Verschillende studies laten zien dat de baten van R\&D en innovatie ruimschoots opwegen tegen de kosten (Alston, 2010).

Nederland heeft een unieke positie in de wereld op het gebied van R\&D in de agribusiness. Door middel van samenwerkingsverbanden tussen bedrijven en Nederlandse onderzoeksinstellingen en de overheid, hebben vijftien van de twintig grootste agrifood-bedrijven productie- en R\&D-centra gevestigd in Nederland (Invest In Holland, 2021a en 2021b). Ook grote bedrijven buiten de traditionele agribusiness roeren zich. Zo gaat DSM zich bijvoorbeeld volledig richten op het adresseren van maatschappelijke en milieu-uitdagingen van voedselproductie en consumptie wereldwijd (EVMI, 2021). Op deze manier beoogt Nederland wereldwijd een leidende positie in te nemen op het gebied van circulaire landbouw in 2030. Niet onbelangrijk daarin is de preferentie dat het delen van de kennis, technologie en innovaties belangrijker wordt dan de export van producten (Zwarts, 2020).

\section{Investeringen in materiële vaste activa}

Naast de ontwikkeling van nieuwe kennis en kunde en de daarmee samenhangende innovatie, investeren bedrijven ook in bedrijfsmiddelen, zoals grond, gebouwen, machines en computers. Dit is nodig om producten en/of diensten te kunnen produceren en/of leveren. De bedrijfsvoering heeft in de agribusiness met name betrekking op productie en distributie.

Recent onderzoek heeft de samenhang bestudeerd tussen investeringen en arbeidsproductiviteit voor bedrijven in de Europese industrie. Uit dat onderzoek kwam naar voren dat een investering in elk type vaste activa positief samenhangt met de arbeidsproductiviteit, wat impliceert dat industriële bedrijven in Nederland efficiënter investeren dan gemiddeld in Europa (Stundziene, 2019). 


\subsection{Bedrijvendynamiek en werkgelegenheid}

Figuur 5.1 toont de verdeling van het aantal bedrijven naar subsector binnen de overige agribusiness. Drie van de vier bedrijven in deze bedrijfstak behoren tot de groothandel agribusiness of de groep supermarkten, voedingswinkels en markthandel. Beide sectoren waren in 2021 goed voor elk ruim 16.000 bedrijven. Binnen de groothandel agribusiness vormde de groothandel in dranken (geen zuivel) met 23\% in 2019 de grootste subgroep, gevolgd door de groothandel in groenten en fruit (15\%). Ook de vervaardiging van voedingsmiddelen is met ruim 6.000 bedrijven een relatief grote sector binnen de overige agribusiness. De stijging van het aantal bedrijven in deze sector met $18 \%$ sinds 2016 is hoofdzakelijk een gevolg van de toename van het aantal brood- en banketbakkerijen met $23 \%$.

De lichte daling van het aantal bedrijven in de groep supermarkten, voedingswinkel en markthandel sinds 2016 wordt niet zozeer gedreven door een afgenomen aantal supermarkten, maar is vooral een gevolg van een krimp van het aantal groentewinkels (13\%), slagerijen (6\%), viswinkels (6\%) en markthandel in groenten en fruit (5\%). Ook tijdens het coronajaar 2020 zette deze dalende trend in de voedingswinkels zich verder (CBS, 2021g).

Opvallend is ook de verdubbeling van het aantal bedrijven in de drankindustrie sinds 2016, voornamelijk door de sterke stijging van het aantal kleine bierbrouwerijen. In de periode 2007-2017 verviervoudigde het aantal Nederlandse bierbrouwerijen, en tussen 2018 en het derde kwartaal van 2021 groeide dit aantal nog eens met bijna 60\% tot 665 (CBS, 2017b; Statline). De grote meerderheid van deze bierbrouwerijen had slechts 1 of 2 werkzame personen in dienst. Meer algemeen bestaat minder dan $5 \%$ van de gehele drankindustrie uit bedrijven met meer dan 10 werkzame personen. Bij de vervaardiging van machines en chemicaliën is dat veel meer: $32 \%$.

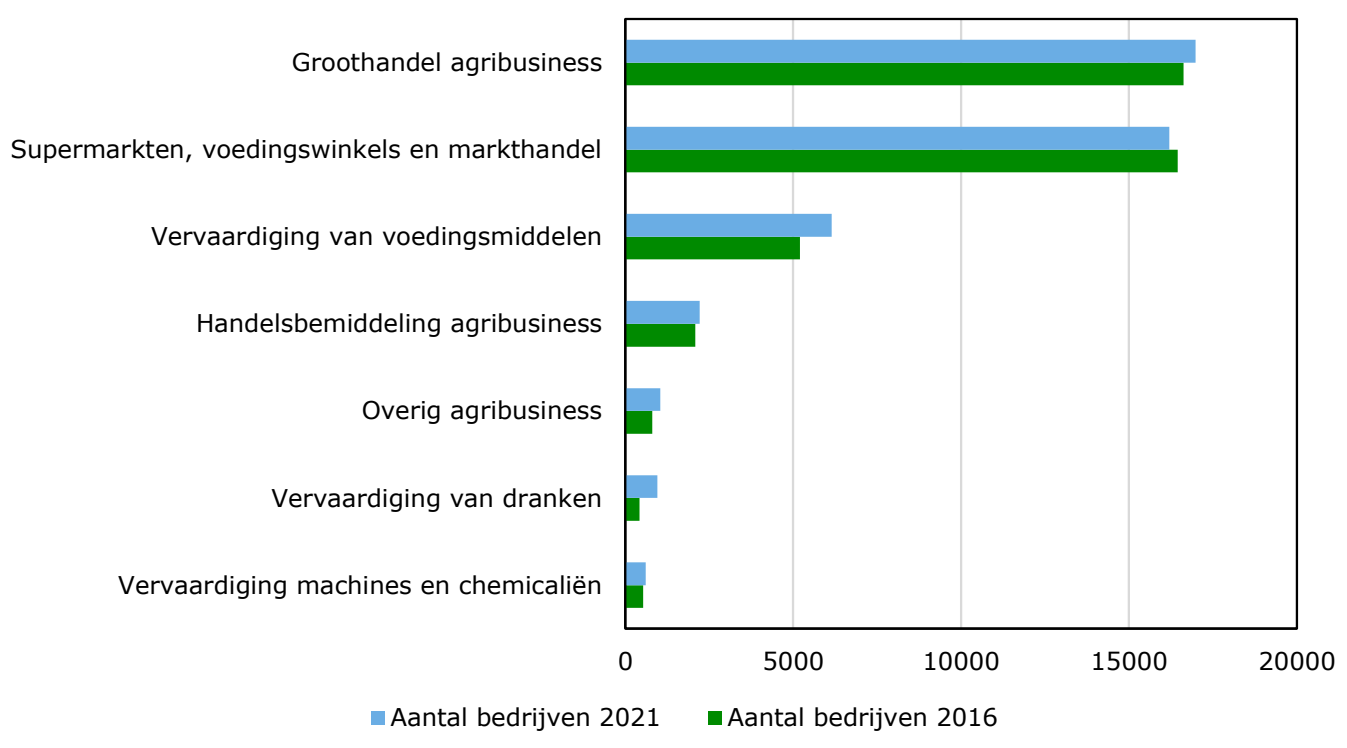

Figuur 5.1 Aantal bedrijven overige agribusiness naar sector Bron: $C B S$.

Aantal bedrijven in overige agribusiness neemt toe

In totaal waren er in 2020 in de overige agribusiness bijna 45.000 bedrijven actief, 5\% meer dan in 2016. Daarmee groeide deze sector iets trager dan de landbouw over diezelfde periode (5,5\%). ${ }^{49}$ Tussen 2020 en 2021 viel de groei van de overige agribusiness in bedrijfsaantallen terug tot bijna stilstand, voornamelijk als gevolg van het grotere aantal bedrijfsopheffingen en het kleinere aantal bedrijfsoprichtingen (zie figuur 5.4).

\footnotetext{
${ }^{49}$ Landbouw is hier gedefinieerd als SBI 01 'Landbouw'. Er is echter een lichte daling indien enkel wordt gekeken naar 011 'Teelt van eenjarige gewassen', 012 'Teelt van meerjarige gewassen', 013 'Teelt van bloembollen en sierplanten', 014 'Veeteelt en fokkerijen' en 015 'Gemengd bedrijf'.
} 
Figuur 5.2 toont dat bedrijven met minder dan 10 werkzame personen veruit de grootste groep vormen binnen de overige agribusiness (89\% in 2021). Deze kleine bedrijven zijn hoofdzakelijk actief in de groothandel agribusiness (39\%) of de supermarkten, voedingswinkels en markthandel (38\%). De groei van de overige agribusiness met $5 \%$ sinds 2016 wordt ook grotendeels gedreven door een toename van deze kleine bedrijven. Sinds 2016 groeide het aantal bedrijven in de overige agribusiness met minder dan 10 werkzame personen met bijna 2.000 bedrijven (5\%). Procentueel gezien groeide de sector wel het hardst in de bedrijven met minstens 50 werkzame personen. Zo groeide het aantal bedrijven met 50-249 werkzame personen met $18 \%$ sinds 2016 en het aantal bedrijven met meer dan 250 werkzame personen met $15 \%$.

Absoluut gezien gaat het daar echter om beperkte aantallen (respectievelijk 160 en 25 bedrijven). Het maakt echter wel dat er ten opzichte van 2016 een iets groter aandeel grote bedrijven actief is in de overige agribusiness. Slechts $0,4 \%$ van de bedrijven in deze bedrijfstak heeft echter 250 of meer werkzame personen in dienst.

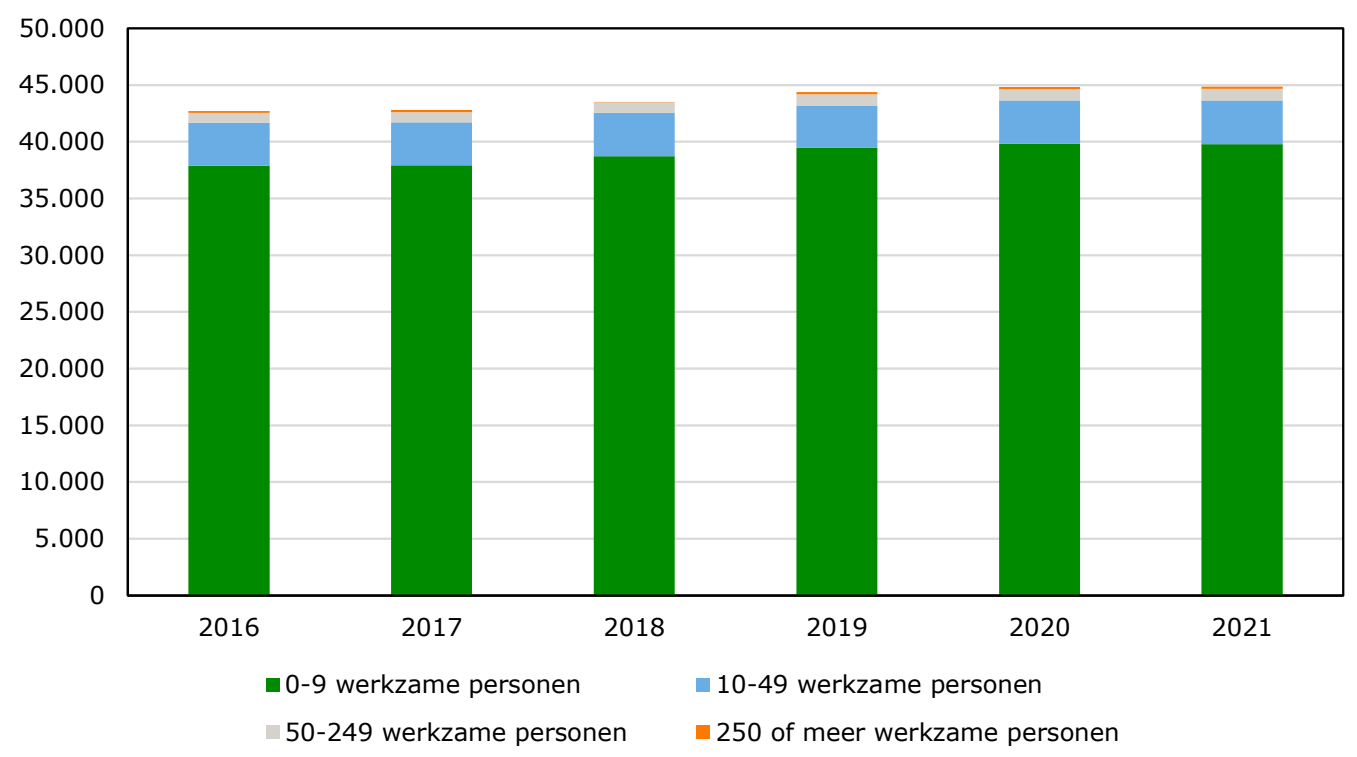

Figuur 5.2 Aantal bedrijven overige agribusiness naar bedrijfsomvang Bron: CBS.

Figuur 5.3 geeft de verdeling van het aantal vestigingen binnen de overige agribusiness naar provincie, ZuidHolland en Noord-Holland nemen aandelen van respectievelijk 23\% en $18 \%$ voor hun rekening. Daarbij heeft Noord-Holland relatief gezien wat meer vestigingen in de drankindustrie, de voedingsindustrie en de groep supermarkten, voedingswinkels en markthandel dan Zuid-Holland. Deze laatste provincie heeft dan weer een wat groter aandeel vestigingen in de groothandel agribusiness. Groningen en Flevoland zijn de provincies met het kleinste percentage vestigingen in de overige agribusiness.

Ten opzichte van 2016 steeg het aantal vestigingen binnen de overige agribusiness relatief gezien het meest in Noord-Holland (10\%) en Utrecht ( $8 \%$ ). In beide provincies was daarbij sprake van een vrij sterke groei in de voedingsindustrie (meer dan 20\%) en de drankindustrie (meer dan 70\%). Limburg en Friesland zijn de enige provincies waar het aantal vestigingen tussen 2016 en 2020 (licht) daalde. In Limburg was dat voornamelijk een gevolg van een afname van het aantal vestigingen in de groep supermarkten, voedingswinkels en markthandel met $5 \%$. Friesland kende eveneens een daling in deze categorie (3\%), maar daar daalde ook het aantal vestigingen in de groothandel agribusiness relatief sterk (7\%). 


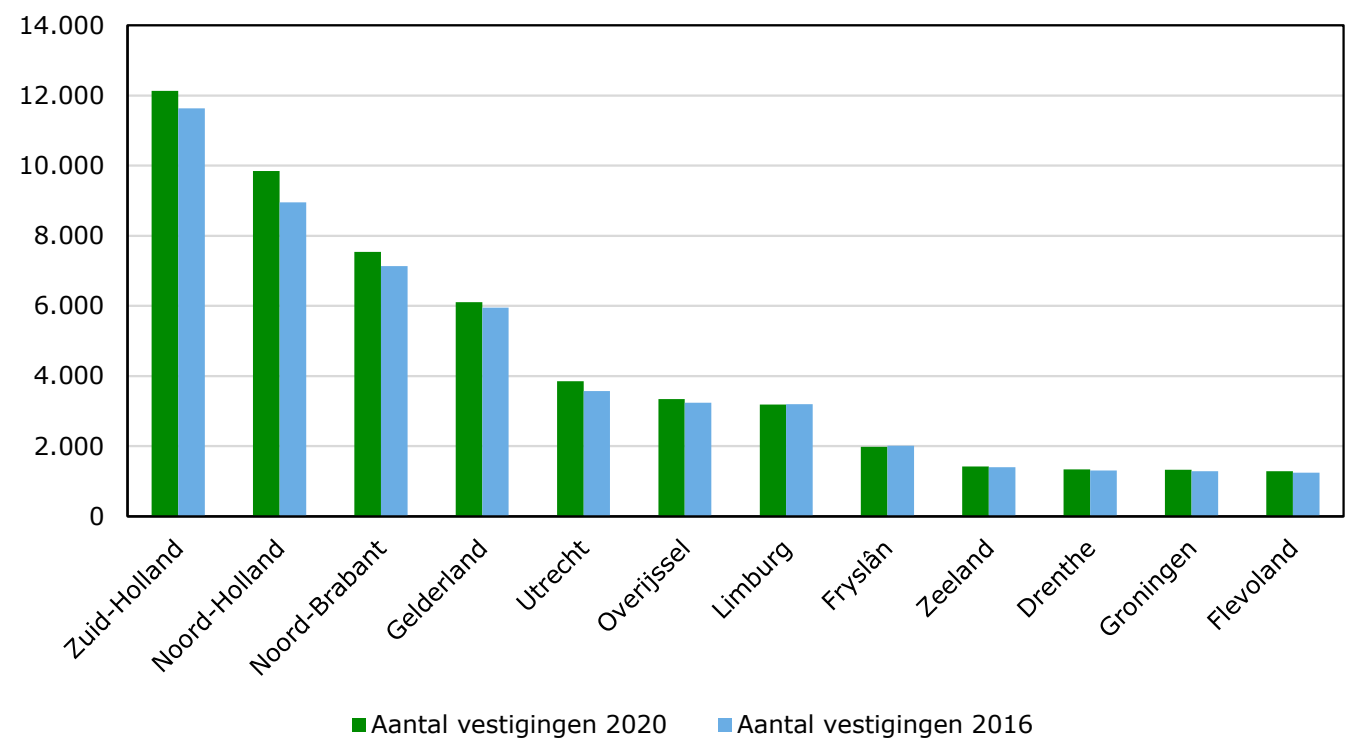

Figuur 5.3 Aantal vestigingen overige agribusiness naar provincie Bron: CBS.

Bedrijfsoprichtingen en -opheffingen in de overige agribusiness

De ontwikkeling van het aantal bedrijven in de overige agribusiness houdt rechtstreeks verband met de dynamiek in de bedrijfsoprichtingen en -opheffingen in deze sector. Figuur 5.4 toont dat tussen 2016 en 2020 het aantal bedrijfsoprichtingen in de overige agribusiness hoger lag dan het aantal opheffingen. Dit verklaart de groei van deze bedrijfstak weergegeven in figuur 5.2. Sinds 2017 is er sprake van een graduele daling van het aantal oprichtingen en tegelijkertijd een stijging van het aantal opheffingen. Die daling is voornamelijk een gevolg van het lager aantal oprichtingen en hoger aantal opheffingen in de groothandel agribusiness en in de supermarkten, voedingswinkels en markthandel. Bij die laatste groep was het aantal oprichtingen in $202033 \%$ lager dan in 2016. Zoals eerder besproken bij figuur 5.1 is deze krimp niet zozeer zichtbaar bij de supermarkten, maar eerder bij bepaalde typen voedingswinkels en markthandel. ${ }^{50}$

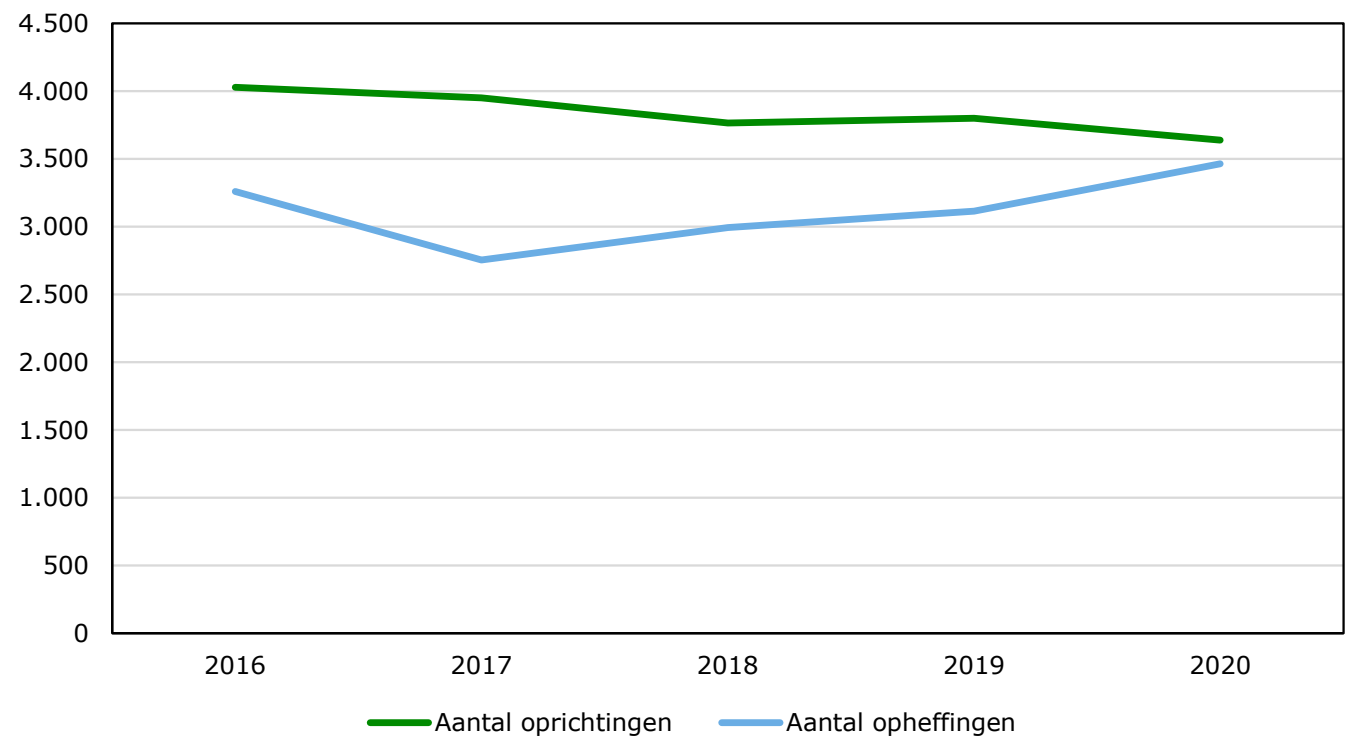

Figuur 5.4 Aantal bedrijfsoprichtingen, bedrijfsopheffingen, fusies en overnames in de overige agribusiness Bron: $C B S$.

\footnotetext{
${ }^{50}$ Zie ook volgende StatLinetabel op het niveau van SBI 3-digit: http://opendata.cbs.nl/statline/\#/CBS/nl/dataset/83148NED/table?dl=5AAED
} 
Kenmerken van het personeel in de overige agribusiness

Als we kijken naar het aantal arbeidsjaren dat wordt vertegenwoordigd door bedrijven in de overige agribusiness, dan is de sectorale verdeling iets anders dan in figuur 5.1. Figuur 5.5 laat zien dat er in 2020 417.000 arbeidsjaren werden verwezenlijkt in de overige agribusiness. ${ }^{51}$ Daarvan vormen de supermarkten, voedingswinkels en markthandel met 170.000 arbeidsjaren de grootste subsector, goed voor $41 \%$ van het totaal. Hierna volgen de groothandel agribusiness (107.000 arbeidsjaren) en de voedingsmiddelenindustrie (104.000 arbeidsjaren). Hoewel de groothandel de grootste sector is wat betreft het aantal bedrijven binnen de overige agribusiness, geldt dat dus niet voor het aantal arbeidsjaren dat er wordt gewerkt. Bij bedrijven in de groep supermarkten, voedingswinkels en markthandel werden gemiddeld genomen dus meer arbeidsjaren gewerkt dan bij bedrijven in de overige agribusiness.

Tussen 2016 en 2020 steeg het totaal aantal gewerkte arbeidsjaren in de overige agribusiness met ruim $13 \%$. Daarmee groeide het aantal arbeidsjaren in die periode sterker dan het aantal bedrijven (4,9\%). Bedrijven in deze bedrijfstak hebben met andere woorden gemiddeld meer mensen in dienst genomen en/of er werden gemiddeld meer uren gewerkt. De stijging vond vooral plaats in de voedingsmiddelenindustrie (7\%), de groothandel agribusiness (10\%) en de supermarkten, voedingswinkels en markthandel (20\%). Die laatste sector kende bovendien een relatief sterke stijging van het aantal arbeidsjaren van bijna $6 \%$ in het coronajaar 2020, in vergelijking met een stijging van 2,5\% een jaar eerder. Dit heeft wellicht te maken met de noodzaak extra maatregelen te nemen in verband met corona en met de gestegen uitgaven aan voeding tijdens deze periode ( $2 \%$ in 2020 ).

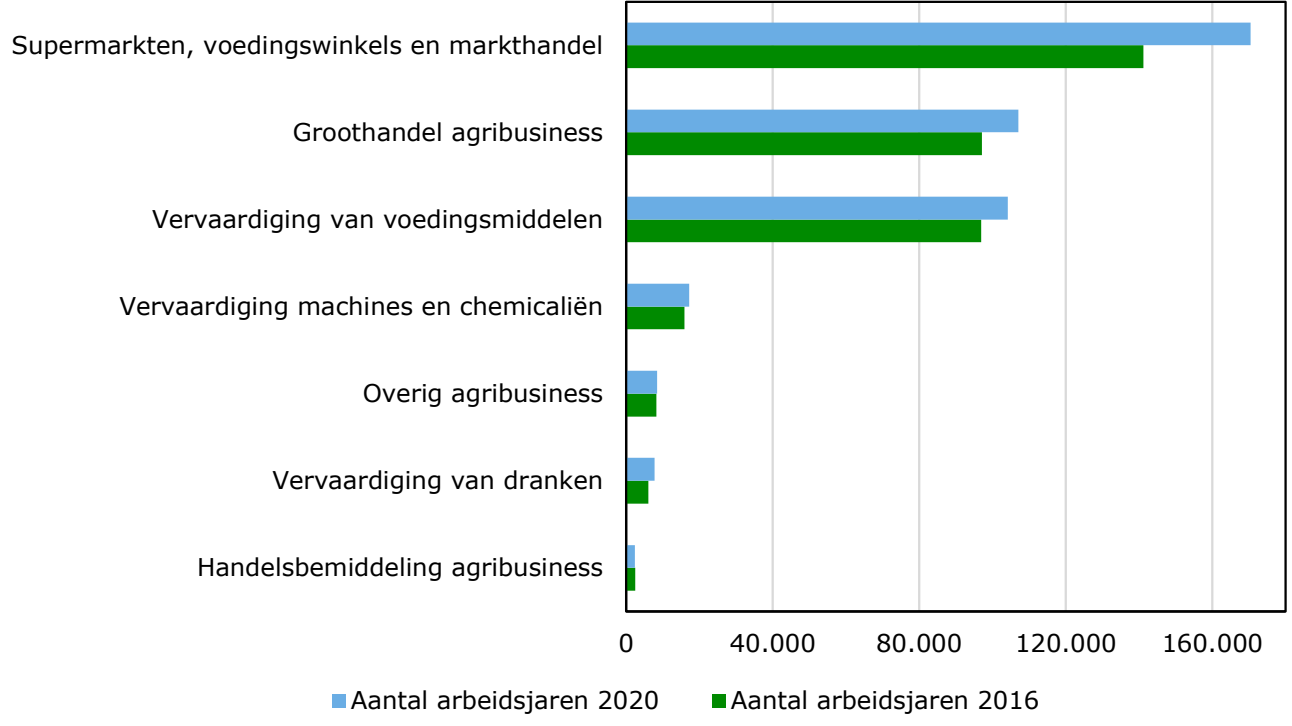

Figuur 5.5 Aantal arbeidsjaren naar sector binnen de overige agribusiness Bron: CBS.

In het totaal werd in 2020 61\% van de arbeidsjaren in de agribusiness gewerkt door mannen. Binnen de onderscheiden subsectoren zijn er echter aanzienlijke verschillen met betrekking tot de verdeling van de arbeidsjaren naar geslacht. Figuur 5.6 toont dat in bijna alle subsectoren mannen de grote meerderheid van de arbeidsjaren uitmaken. Dat geldt het meest in de vervaardiging van machines en chemicaliën ( $90 \%)$ en de vervaardiging van dranken (80\%). In de supermarkten, voedingswinkels en markthandel maken vrouwen daarentegen $55 \%$ van de arbeidsjaren uit.

\footnotetext{
${ }^{51}$ Het betreft in deze paragraaf bijna uitsluitend personen die in directe dienst zijn. De meeste uitzendkrachten kunnen met de gebruikte CBS-microdata namelijk niet aan de juiste sectoren worden toegeschreven en blijven daardoor buiten beschouwing.
} 


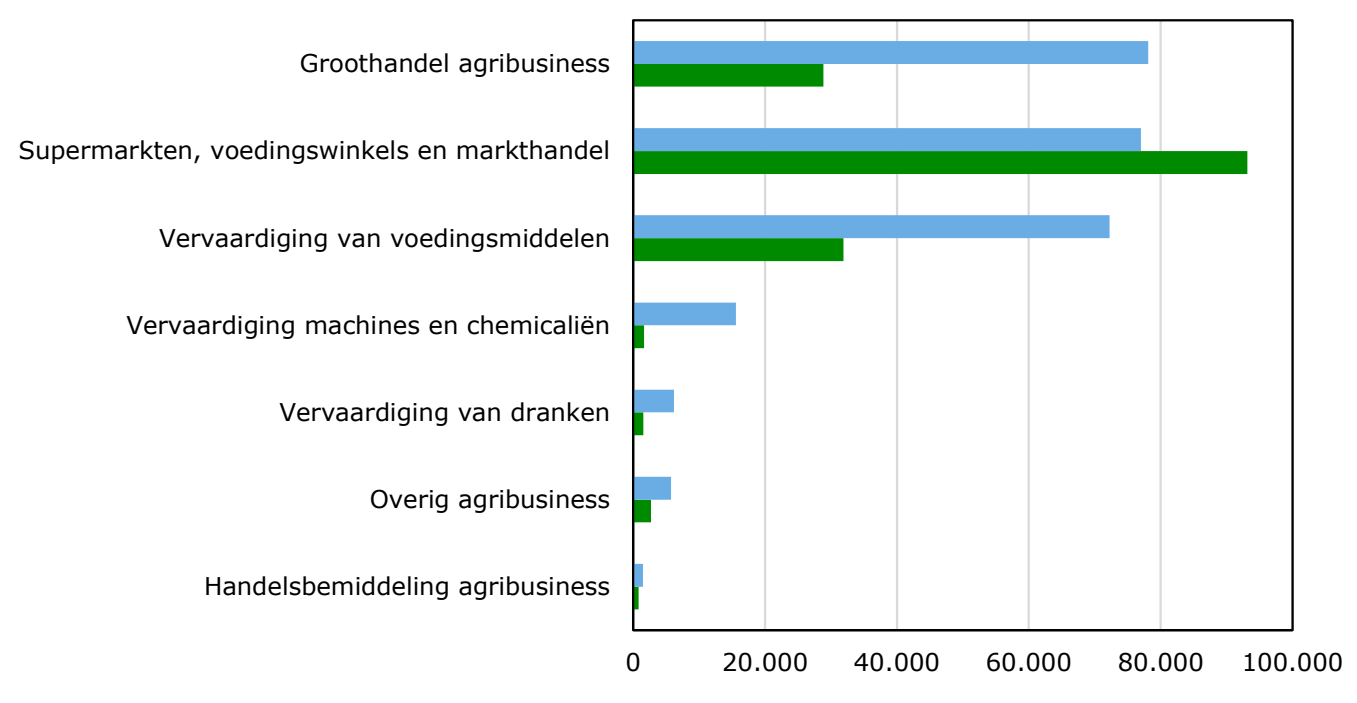

- Aantal arbeidsjaren mannen 2020 - Aantal arbeidsjaren vrouwen 2020

Figuur 5.6 Aantal arbeidsjaren naar sector en geslacht binnen de overige agribusiness Bron: CBS.

Naast geslacht kunnen de arbeidsjaren ook worden verbijzonderd naar de nationaliteit van de werknemers. Figuur 5.7 laat zien dat 8,7\% van de arbeidsjaren in 2020 werd gewerkt door personen met een buitenlandse nationaliteit. Ten opzichte van 2016 komt dat neer op een stijging van 2,3 procentpunten. In de supermarkten, voedingswinkels en markthandel werkt het kleinste aandeel werknemers met een buitenlandse nationaliteit (4\%). Het grootste aandeel buitenlandse werknemers vinden we daarentegen in de industriële vervaardiging van voedingsmiddelen ${ }^{52}(12 \%)$ en de groothandel agribusiness (14\% van de arbeidsjaren).

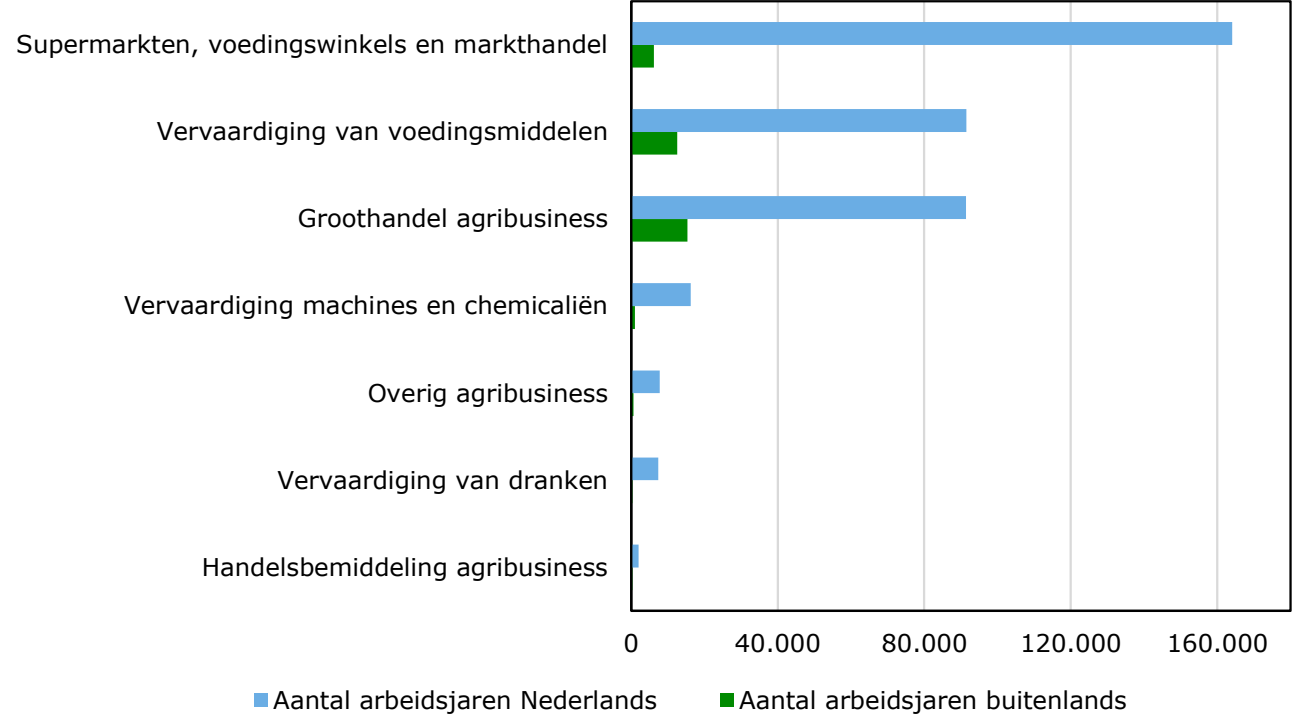

Figuur 5.7 Aantal arbeidsjaren naar sector en nationaliteit binnen de overige agribusiness Bron: CBS.

\footnotetext{
52 Dit is een vrij brede groep van industriële bedrijven uit SBI 10, van slachterijen en vleesverwerking en visverwerking tot de vervaardiging van zuivelproducten, oliën en vetten, meel en diervoeder maar ook de verwerking van aardappelen, groenten en fruit en de industriële vervaardiging van brood- en bakkerijproducten (geen bakkers).
} 
Binnen de verschillende subsectoren bestaat er nog verdere variatie. Zo had in 2020 één op de vier werknemers in Nederlandse slachterijen en vleesverwerkingsbedrijven een buitenlandse nationaliteit. De laatste vijf jaar is het aantal buitenlandse werknemers in deze sector bovendien met meer dan de helft gestegen. Vaak gaat het om arbeidsmigranten (SEO Economisch onderzoek, 2020).

Het gemiddelde bruto-uurloon ${ }^{53}$ van werknemers in de overige agribusiness bedroeg bijna 20 euro per uur in 2020 (zie figuur 5.8). Dat is minder dan gemiddeld in Nederland (26,5 euro), wat voornamelijk samenhangt met het grote aantal studenten en scholieren in de overige agribusiness, met name in de supermarkten. Ten opzichte van een jaar eerder steeg het gemiddelde bruto-uurloon in de overige agribusiness met bijna $2 \%$ en in vergelijking met 2016 met bijna 6\%. In Nederland als geheel steeg het bruto-uurloon sinds 2016 met $8,5 \%$ iets meer dan in de overige agribusiness. Het totaalcijfer van 20 euro per uur in de overige agribusiness verhult bovendien een groot verschil tussen mannen en vrouwen. Gemiddeld verdienden mannen met 23 euro per uur ruim 7 euro bruto per uur meer dan vrouwen in deze sector.

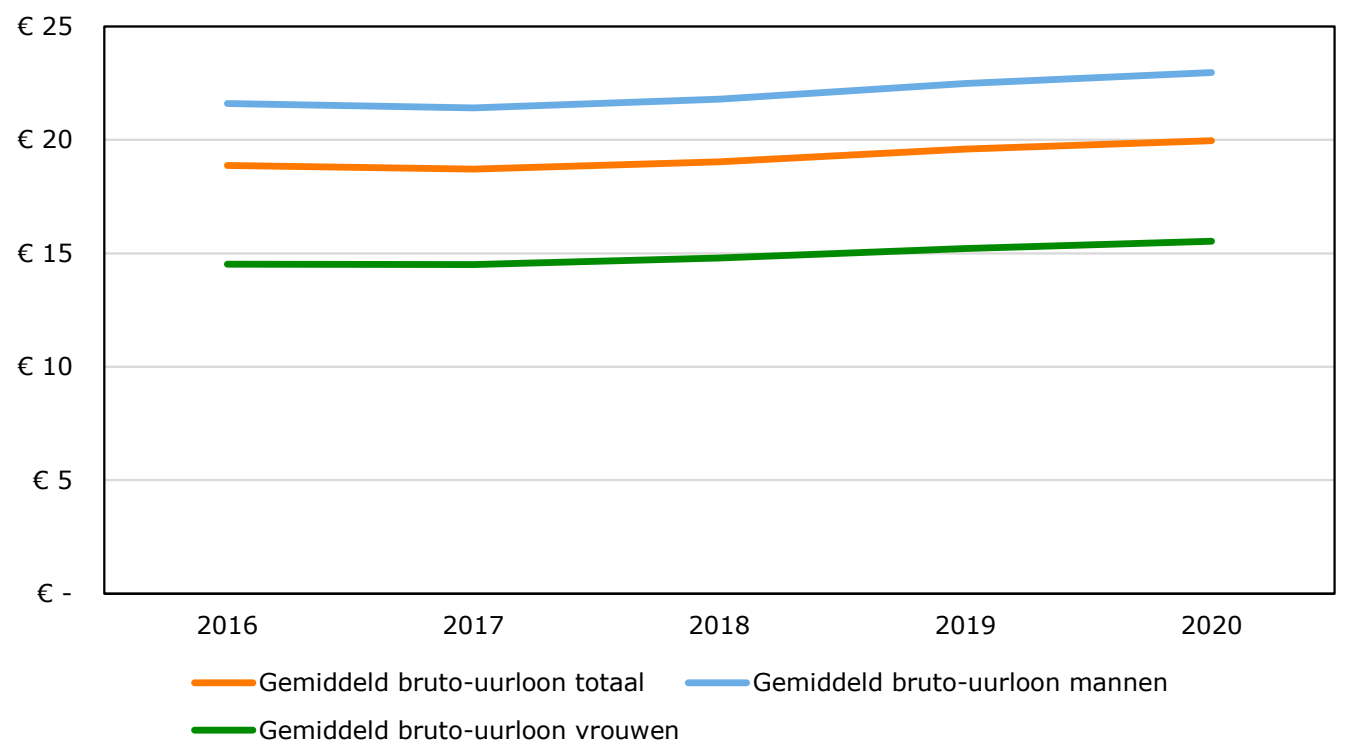

Figuur 5.8 Gemiddelde bruto-uurloon in de overige agribusiness naar geslacht Bron: $C B S$.

Het verschil in beloning tussen mannen en vrouwen is onder meer een weerspiegeling van de verschillende subsectoren van de overige agribusiness waar mannen en vrouwen werkzaam zijn. Figuur 5.9 laat zien dat supermarkten, voedingswinkels en markthandel veruit het laagste bruto-uurloon betalen, en daar werken relatief veel vrouwen (zie figuur 5.6). Vrouwen verdienen er gemiddeld 11,2 euro per uur. Het lage brutouurloon in deze sector is ook deels een gevolg van het grote aandeel studenten en scholieren dat er werkzaam is.

Verder toont figuur 5.9 dat werknemers in de drankindustrie en de handelsbemiddeling agribusiness de hoogste bruto-uurlonen verdienen binnen de overige agribusiness. In alle onderscheiden sectoren verdienen mannen gemiddeld een hoger bruto-uurloon dan vrouwen. Vooral in de handelsbemiddeling agribusiness en de voedingsmiddelenindustrie is deze afstand relatief groot.

\footnotetext{
${ }^{53}$ Het gemiddelde bruto-uurloon is hier berekend als een gewogen gemiddelde van de mediane bruto-uurlonen bij de verschillende bedrijven. Daarbij zijn de gewichten bepaald op basis van de bedrijfsomvang in arbeidsjaren. De berekening van het brutouurloon houdt ook rekening met vakantiegelden, eindejaarsuitkeringen, het aantal overwerkuren en de compensatie hiervoor.
} 


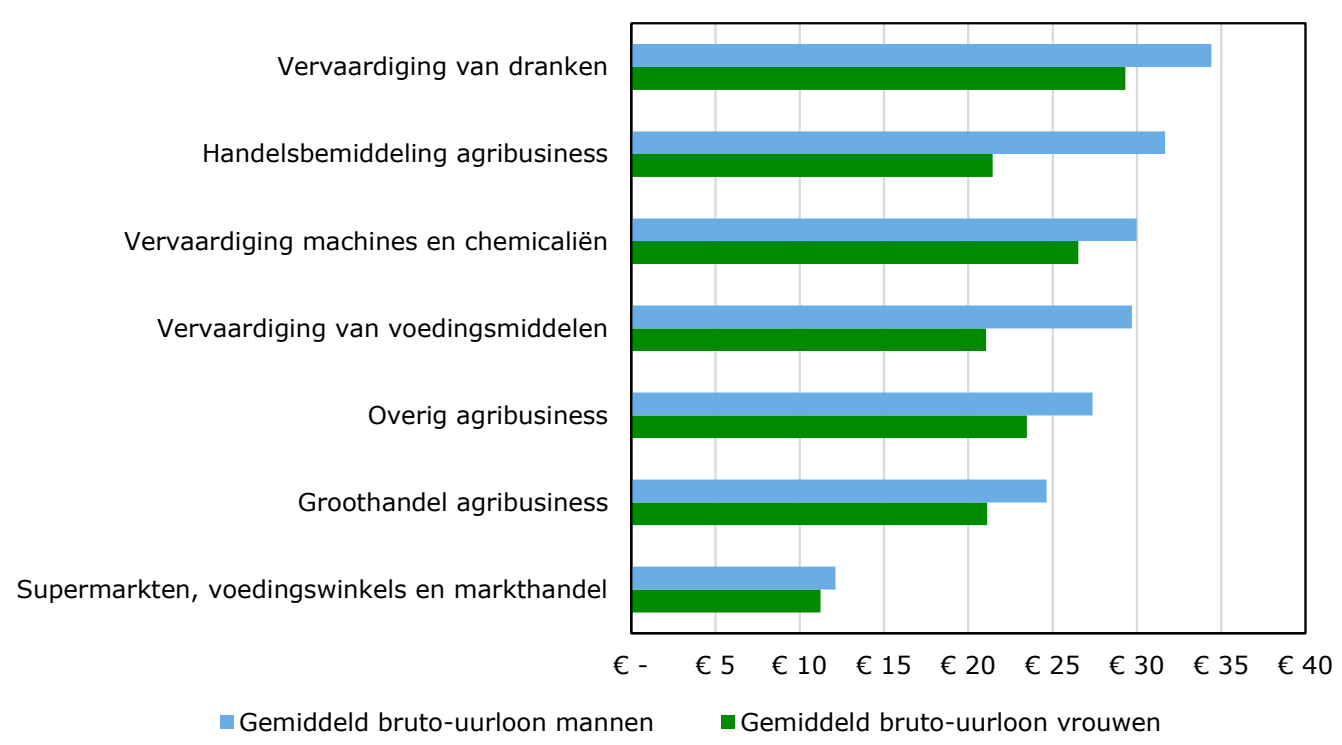

Figuur 5.9 Gemiddelde bruto-uurloon in de overige agribusiness naar geslacht en sector Bron: CBS.

Ondernemers in de overige agribusiness

Deze paragraaf gaat dieper in op de ondernemers achter de bedrijven in de overige agribusiness. Een ondernemer is een persoon die arbeid verricht voor eigen rekening of risico in een eigen bedrijf of praktijk (zelfstandig ondernemer) of als directeur in loondienst van een eigen bedrijf (directeur-grootaandeelhouder). In totaal waren er in 2020 binnen de overige agribusiness bijna 55 duizend ondernemers actief, hoofdzakelijk in de groothandel agribusiness en de supermarkten, voedingswinkels en markthandel.

Sinds 2016 is het aantal ondernemers met een bedrijf in de overige agribusiness met bijna 5\% afgenomen. Die daling vond voornamelijk plaats in de groothandel agribusiness en in de supermarkten, voedingswinkels en markthandel (zie figuur 5.10). Ten opzichte van 2016 daalde het aantal ondernemers in deze sectoren met respectievelijk $6,6 \%$ en $9,1 \%$. De andere subsectoren kenden een groei van het aantal ondernemers in die periode. De vervaardiging van dranken, waartoe de vervaardiging van bier, wijn en frisdranken behoort, kende zelfs bijna een verdubbeling van het aantal ondernemers. Daarbij betrof het wel bijna hoofdzakelijk bedrijven met minder dan 10 werkzame personen. ${ }^{54}$

\footnotetext{
${ }^{54}$ Zie ook volgende tabel op StatLine: https://mkbstatline.cbs.nl/\#/MKB/nl/dataset/48001NED/table?dl=5A14B
} 
Supermarkten, voedingswinkels en markthandel

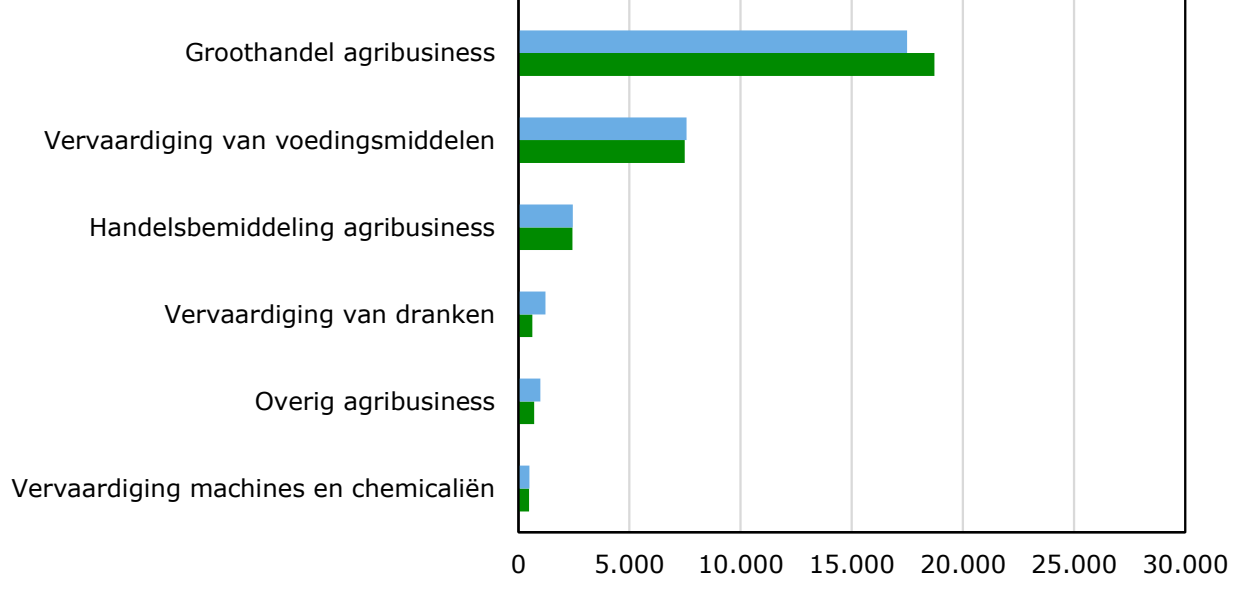

-Aantal ondernemers $2020 \quad$ Aantal ondernemers 2016

Figuur 5.10 Aantal ondernemers in de overige agribusiness naar sector Bron: $C B S$.

In 2020 was bijna één op de drie ondernemers die aan het roer stond van een bedrijf dat actief is in de overige agribusiness vrouw. Dit aandeel is al minstens 10 jaar onveranderd en geldt ook in de primaire landbouw. Ondanks dat mannen in alle sectoren van de overige agribusiness in de meerderheid zijn, bestaan er wel aanzienlijke verschillen in de verdeling naar geslacht over de verschillende subsectoren (zie figuur 5.11). Mannelijke ondernemers komen relatief gezien het vaakst voor in de vervaardiging van dranken ( $12 \%$ is vrouw) en de vervaardiging van machines en chemicaliën ( $13 \%$ is vrouw). De sterkste vertegenwoordiging van vrouwelijke ondernemers zien we daarentegen in de vervaardiging van voedingsmiddelen (42\%) en in supermarkten, voedingswinkels en markthandel (35\%).

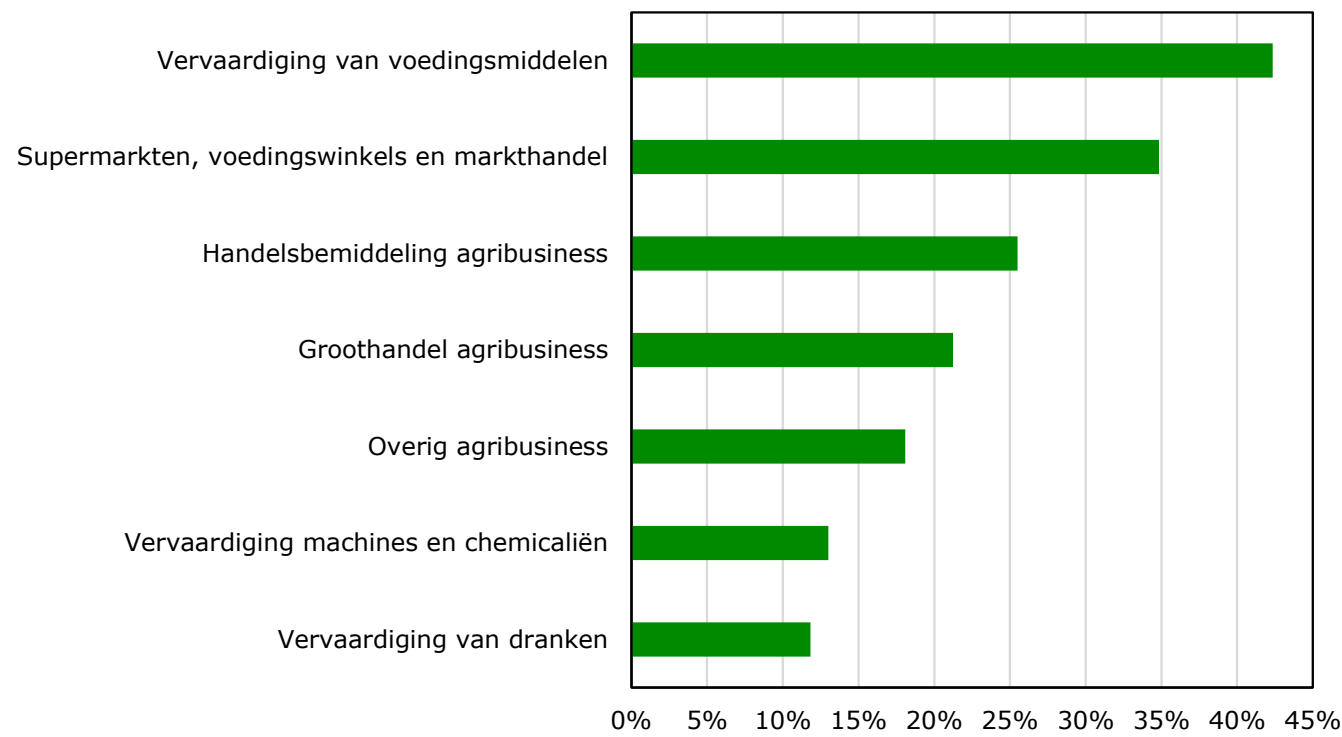

Figuur 5.11 Aandeel vrouwelijke ondernemers in de overige agribusiness naar sector Bron: CBS.

Ongeveer de helft van de ondernemers in de overige agribusiness was in 2020 tussen de 46 en 64 jaar oud, en iets meer dan $10 \%$ was ouder dan 64 (zie figuur 5.12). Dat maakt de ondernemersgroep in de overige 
agribusiness iets minder vergrijsd dan in de primaire landbouw, waar deze percentages respectievelijk $51 \%$ en $16 \%$ bedragen (zie ook paragraaf 4.2 .6 ).

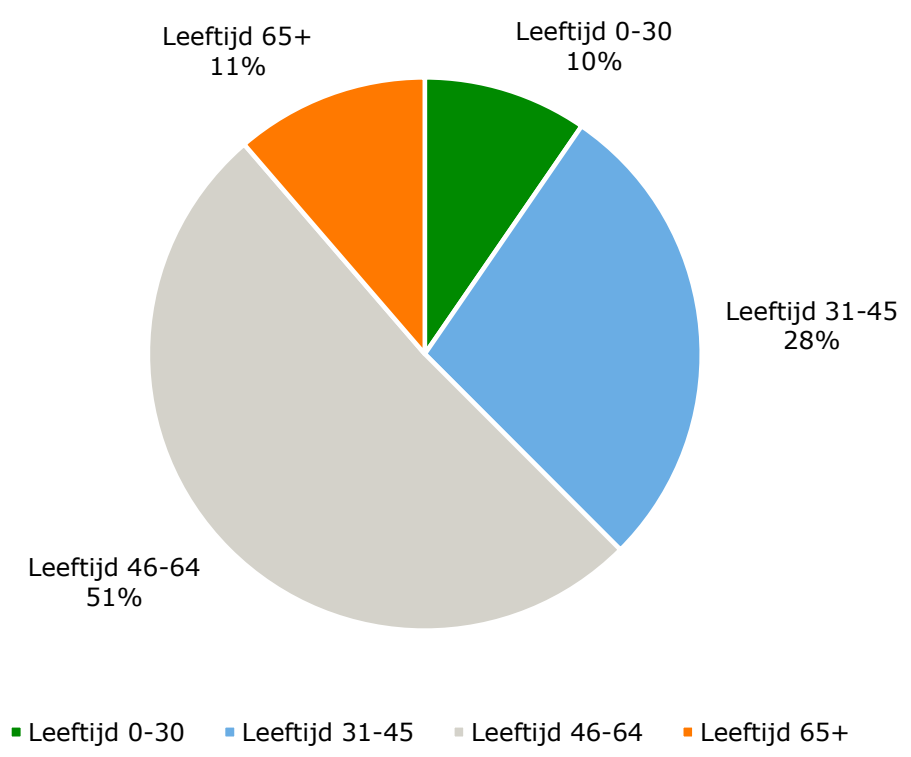

Figuur 5.12 Leeftijdsverdeling ondernemers in de overige agribusinessG106 Bron: CBS.

\subsection{Innovatie in de Nederlandse agribusiness}

Het CBS doet tweejaarlijks via de Community Innovation Survey (CIS) onderzoek naar innovatie bij bedrijven. ${ }^{55}$ Hierbij worden product- en bedrijfsprocesprocesinnovaties onderscheiden. Ook wordt gekeken naar de uitgaven aan innovatie en naar samenwerkingsverbanden bij innovatie. In deze paragraaf besteden we aandacht aan innovatie bij bedrijven in Nederland en specifiek bedrijven in de agribusiness. Vanwege het steekproefkarakter is het onmogelijk om de agribusiness te scheiden tussen primaire landbouw en overig agribusiness. Om die reden kijken we naar de agribusiness als geheel.

Figuur 5.13 laat het aandeel innovatieve bedrijven zien binnen de populatie van bedrijven met 10 werkzame personen of meer. Bijna 30\% van bedrijven in de agribusiness met tien of meer werkzame personen hielden zich in de periode 2016-2018 op de een of andere manier bezig met innovatie. Bij alle bedrijven in Nederland was dat aandeel $37 \%$. 2\% van de bedrijven in Nederland werkte in die periode aan innovaties zonder deze te voltooien (nog lopend of afgebroken), evenveel als het aandeel bedrijven in de agribusiness.

\footnotetext{
${ }^{55} \mathrm{Er}$ is daarnaast de innovatiemonitor (Van Galen en Van der Meer, 2020). In deze monitor gaat het specifiek over het innovatiegedrag van ondernemers in de land- en tuinbouw (zie paragraaf 4.2.8).
} 


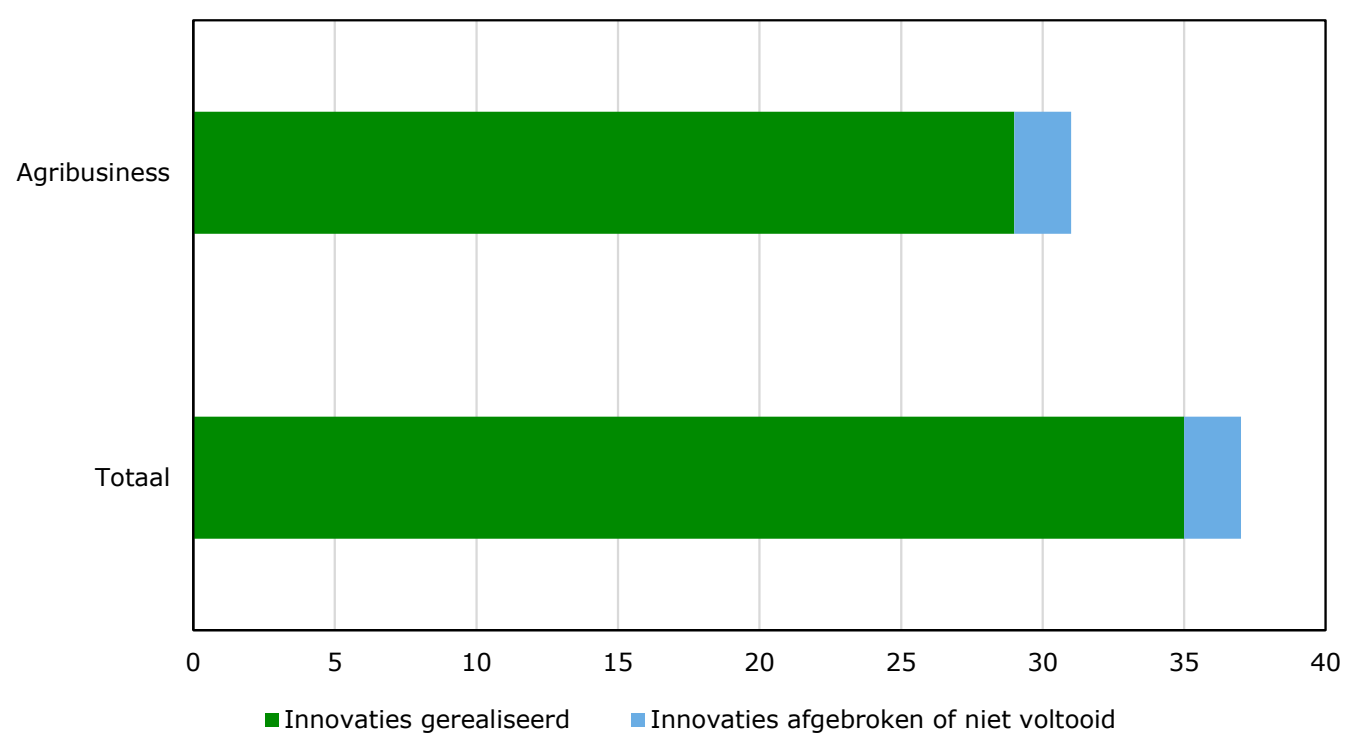

Figuur 5.13 Bedrijven met innovatieve activiteiten, 2016-2018

Bron: $C B S$.

In de enquête wordt onderscheid gemaakt tussen verschillende typen innovatie, zie ook figuur 5.14. Van de bedrijven die succesvol hebben geïnnoveerd, werkte zowel in de agribusiness als voor bedrijven totaal in Nederland het grootste deel aan bedrijfsprocesinnovatie, namelijk $90 \%$ respectievelijk $88 \%$. Van bedrijven met succesvolle innovaties werkte $12 \%$ uitsluitend aan productinnovatie en $38 \%$ combineerde dit met procesinnovatie. Vooral bedrijven in de agribusiness die niet onder de industrie vallen zijn meer gefocust op procesinnovatie dan op productinnovatie.

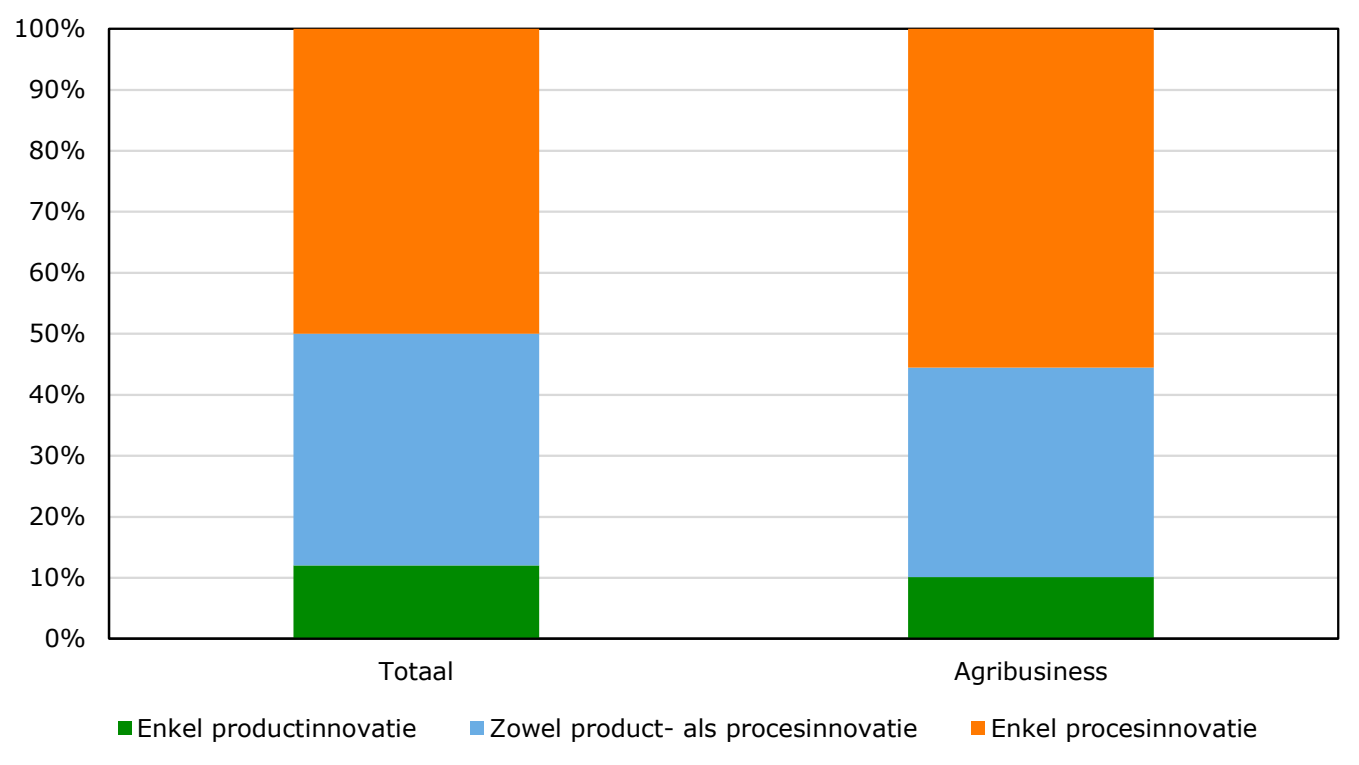

Figuur 5.14 Product- en bedrijfsprocesinnovators, 2016-2018 Bron: $C B S$.

Naast in kaart te hebben welk aandeel van bedrijven aan innovaties en aan welk type innovatie werken, is het ook van belang te weten of bedrijven bij dit innovatieproces hebben samengewerkt in het kader van de publiek-private samenwerking die in Nederland prominent wordt uitgedragen. 
Zowel bij alle bedrijven als bij bedrijven in de agribusiness werkte 32\% bij innovatieactiviteiten samen met één of meerdere partners (tabel 5.1). In het kader van het belang van publiek-private samenwerking, lichten we drie typen samenwerkingspartners uit: andere bedrijven binnen het concern, universiteiten en hogere onderwijsinstellingen en overheidsinstellingen. De som van deze samenwerkingsverbanden telt niet op tot het totaal aandeel samenwerkende innovatoren, omdat bedrijven kunnen samenwerken met meer dan één partner en er ook nog andere typen samenwerkingsverbanden bestaan. Bij de drie genoemde samenwerkingspartners zijn er wel verschillen. Zo werken innovators in de agribusiness vaker samen bedrijven binnen het eigen concern, met universiteiten en met de overheid.

Tabel 5.1 Product- en bedrijfsprocesinnovators, 2016-2018

\begin{tabular}{lrrrr}
\hline & $\begin{array}{r}\text { Samenwerkende } \\
\text { innovators }\end{array}$ & $\begin{array}{r}\text { Andere bedrijven } \\
\text { binnen het concern }\end{array}$ & $\begin{array}{r}\text { Universiteiten of hogere } \\
\text { onderwijsinstellingen }\end{array}$ & $\begin{array}{r}\text { Overheids- of publieke } \\
\text { researchinstellingen }\end{array}$ \\
\hline Totaal & 32 & 12 & 14 & 8 \\
\hline Agribusiness & 32 & 71 & 7 \\
\hline
\end{tabular}

Bron: CBS.

Tot slot kijken we naar de verdeling van de innovatie-uitgaven, figuur 5.15. Innovators in de agribusiness besteden relatief minder aan R\&D (81\%) dan gemiddeld (89\%) en trekken relatief gezien meer geld uit voor de aankoop van machines, apparatuur en software ( $17 \%$ in de agribusiness en $9 \%$ bij alle innovators). Het verschil zit voornamelijk in de aankoop van externe R\&D: dit is gemiddeld genomen in Nederland belangrijker dan machines, apparatuur en software, terwijl in de agribusiness een deel van de aankoop van externe R\&D plaats maakt voor een groter aandeel in de aanschaf van machines.

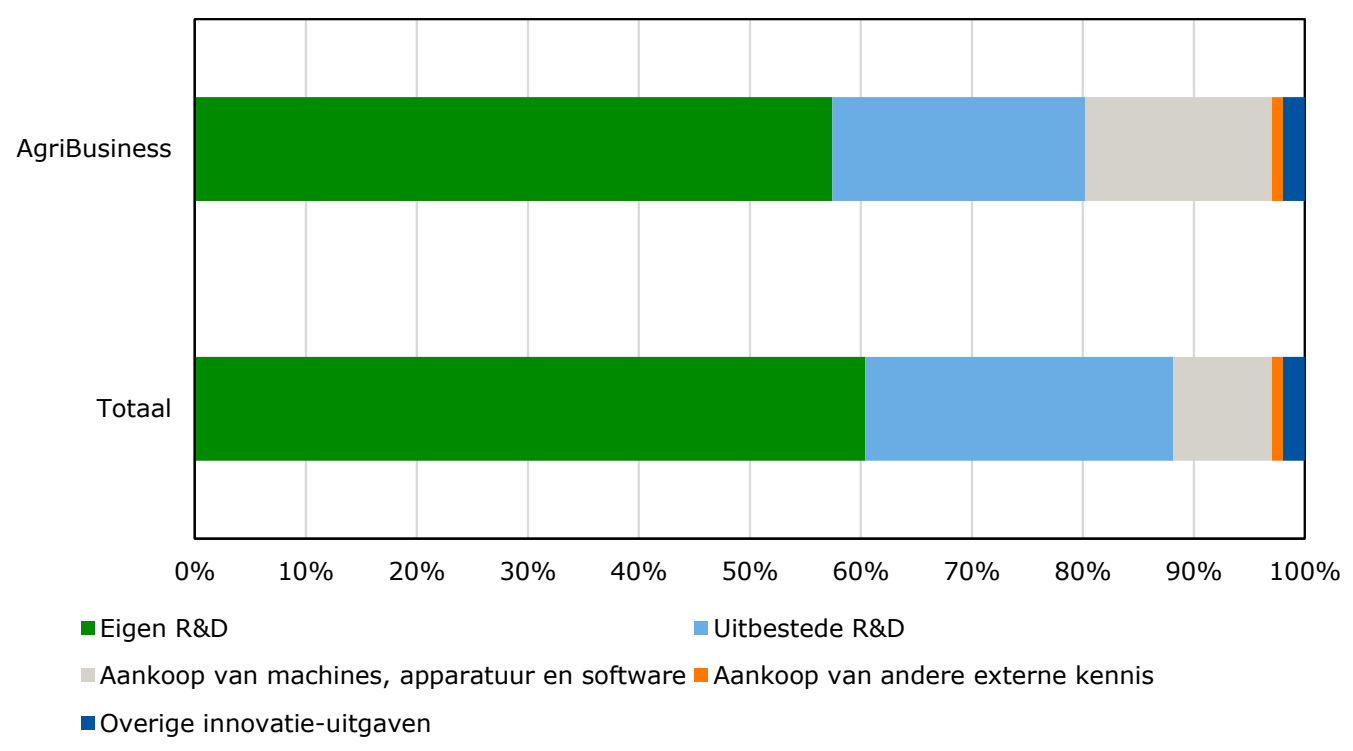

Figuur 5.15 Innovatie-uitgaven, naar categorie, 2018

Bron: CBS.

\subsection{R\&D in de Nederlandse agribusiness door de tijd}

In de periode 2013-2019 zijn de uitgaven aan R\&D met eigen en ingeleend personeel elk jaar gegroeid (figuur 5.16). De R\&D-intensiteit (R\&D-uitgaven afgezet tegen het $b b p$ ) is in deze periode redelijk stabiel gebleven. 


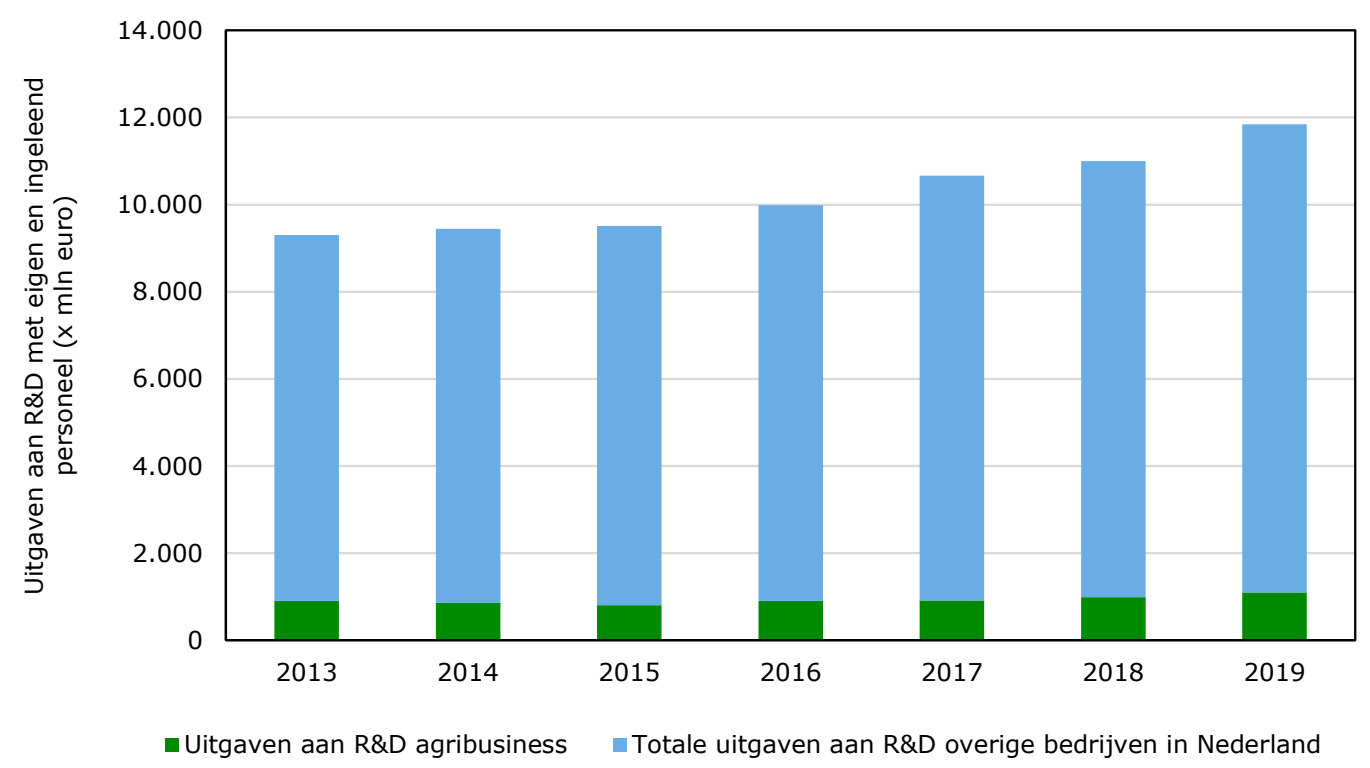

Figuur 5.16 Uitgaven aan R\&D met eigen en ingeleend personeel, 2013-2019 Bron: $C B S$.

In 2013 bedroegen de uitgaven aan R\&D van Nederlandse bedrijven 9,3 mld. euro, tegen 11,8 mld. euro in 2019. De R\&D-uitgaven met eigen en ingeleend personeel van de agribusiness waren tot en met 2018 minder dan een mld. euro. In 2019 spendeerde de agribusiness echter voor het eerst meer dan een mld. aan R\&D (bijna 1,1 mld.). De ontwikkeling van de uitgaven aan R\&D van de agribusiness is over de tijd stabieler dan die van alle bedrijven samen, hier is een grotere stijging zichtbaar. Het aandeel van de agribusiness in de totale R\&D-uitgaven kwam in 2019 uit op 9,2\%. De agribusiness neemt een niet te verwaarlozen aandeel van de totale R\&D in Nederland voor haar rekening.

De gespendeerde arbeidsjaren aan R\&D laten voor Nederland eenzelfde trend zien als de uitgaven, figuur 5.17. In 2018 kwamen deze voor het eerste boven de 100 duizend arbeidsjaren uit en in 2019 bedroegen ze 115.000. Hiervan kwamen 10 duizend arbeidsjaren op het conto van de agribusiness, zo'n $8,7 \%$.

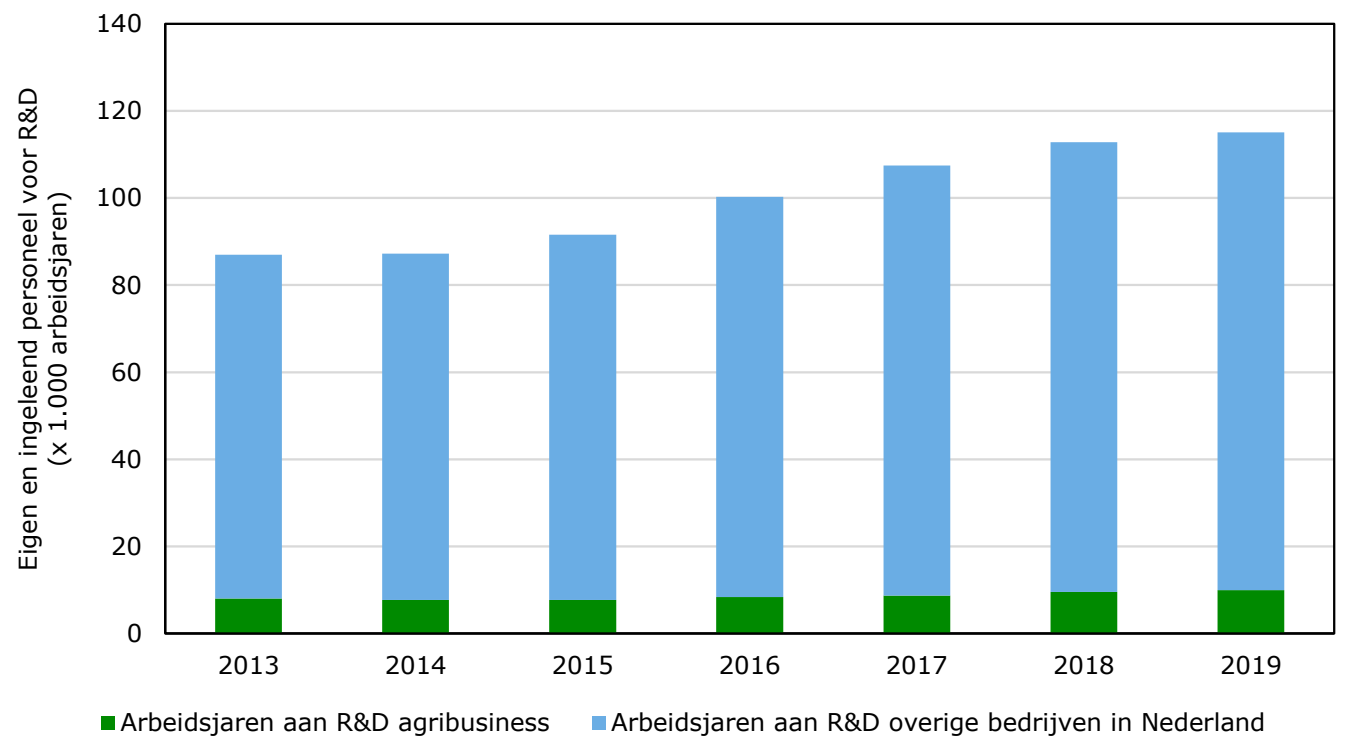

Figuur 5.17 Arbeidsjaren aan R\&D van eigen en ingeleend personeel, 2013-2019 Bron: $C B S$. 
Het is gebruikelijk om de R\&D-uitgaven af te zetten tegen het bbp, zo verkrijgt men de R\&D-intensiteit. De totale R\&D-intensiteit was in 2019 gelijk aan 2,18\%, dit is inclusief instellingen en het hoger onderwijs. De private R\&D-intensiteit in Nederland kwam in 2019 uit op 1,46\%. De bijdrage van de agribusiness was daarin 0,13\%. Over de gehele periode 2013-2019 lag dit aandeel vrij stabiel tussen de $0,12 \%$ en $0,14 \%$. Dit is weergegeven in figuur 5.18 .

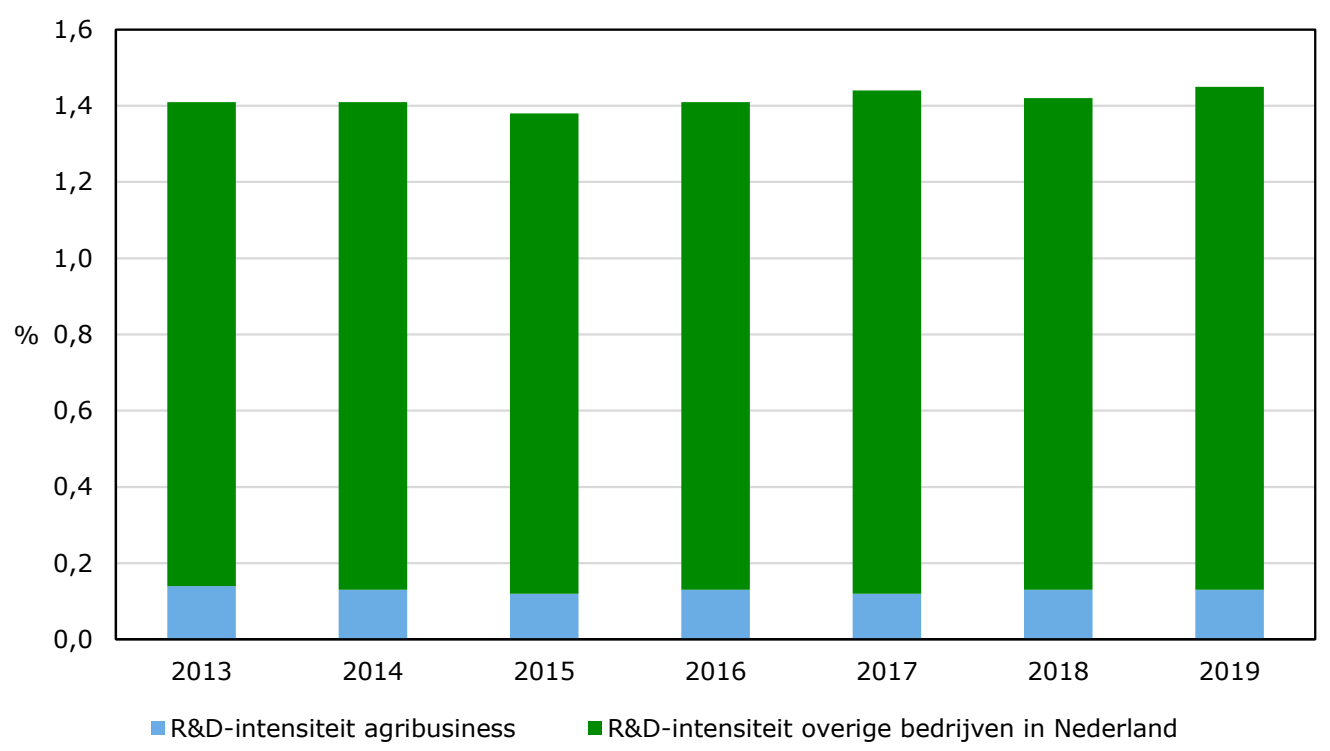

Figuur 5.18 R\&D-intensiteit agribusiness en overige bedrijven in Nederland, 2013-2019 Bron: CBS.

\subsection{Investeringen in materiële vaste activa}

Elk jaar brengt het CBS de investeringen in materiële vaste activa van het niet-financiële Nederlandse bedrijfsleven in kaart, ook wel business economy genoemd. ${ }^{56}$ Een onderdeel hiervan is de overige agribusiness, dit zijn bedrijven actief in de agribusiness uitgezonderd de landbouw, bosbouw en visserij. In de periode 2013-2019 zijn de investeringen opgelopen van 46 mld. euro in 2013 tot ruim 65 mld. euro in 2019 (figuur 5.19). Het aandeel investeringen van de overige agribusiness schommelde in deze periode tussen de 7\% en 9\%, met 7,8\% in 2019. In 2016 kwamen investeringen door bedrijven in de overige agribusiness voor het eerst boven de 4 mld. euro uit, in 2018 voor het eerst boven de 5 mld. euro.

\footnotetext{
${ }^{56}$ De business economy telt de overheidssector niet mee. Ook de landbouw, bosbouw en visserij, financiële dienstverlening, onderwijs, zorg, cultuur, sport en recreatie, belangen en hobby-verenigingen en overige persoonlijke dienstverlening worden niet tot de business economy gerekend. De business economy is dus een deel van alle economische activiteiten.
} 


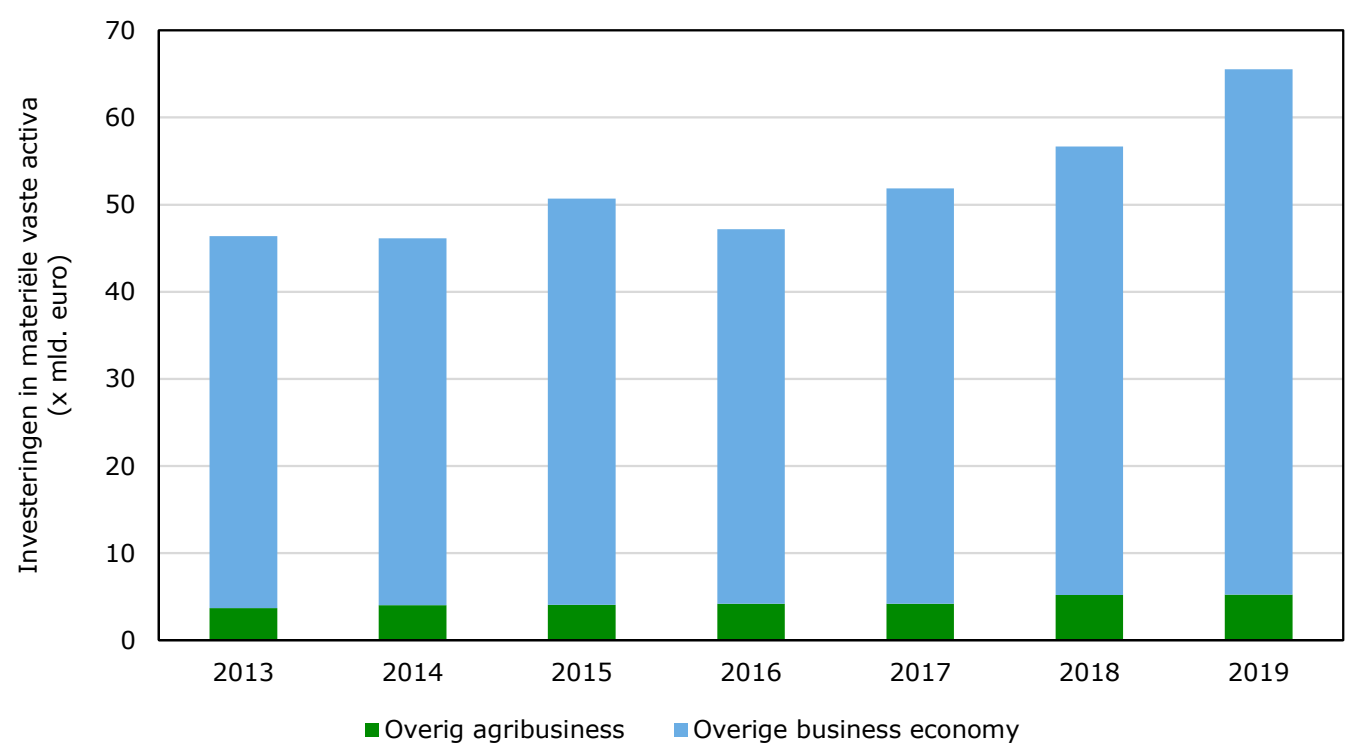

Figuur 5.19 Investeringen in materiële vaste activa: niet-financiële bedrijfsleven en overige agribusiness, 2013-2019

Bron: $C B S$.

De agribusiness exclusief primaire landbouw investeert anders dan het overige niet-financiële bedrijfsleven. Waar het overige bedrijfsleven in 2019 voornamelijk in vervoersmiddelen en bedrijfsgebouwen investeerde, deed de overige agribusiness dat vooral in machines en bedrijfsgebouwen. Bedrijven in de overige agribusiness investeerden relatief veel minder in vervoersmiddelen en grond-, water- en wegenbouwkundige werken (figuur 5.20).

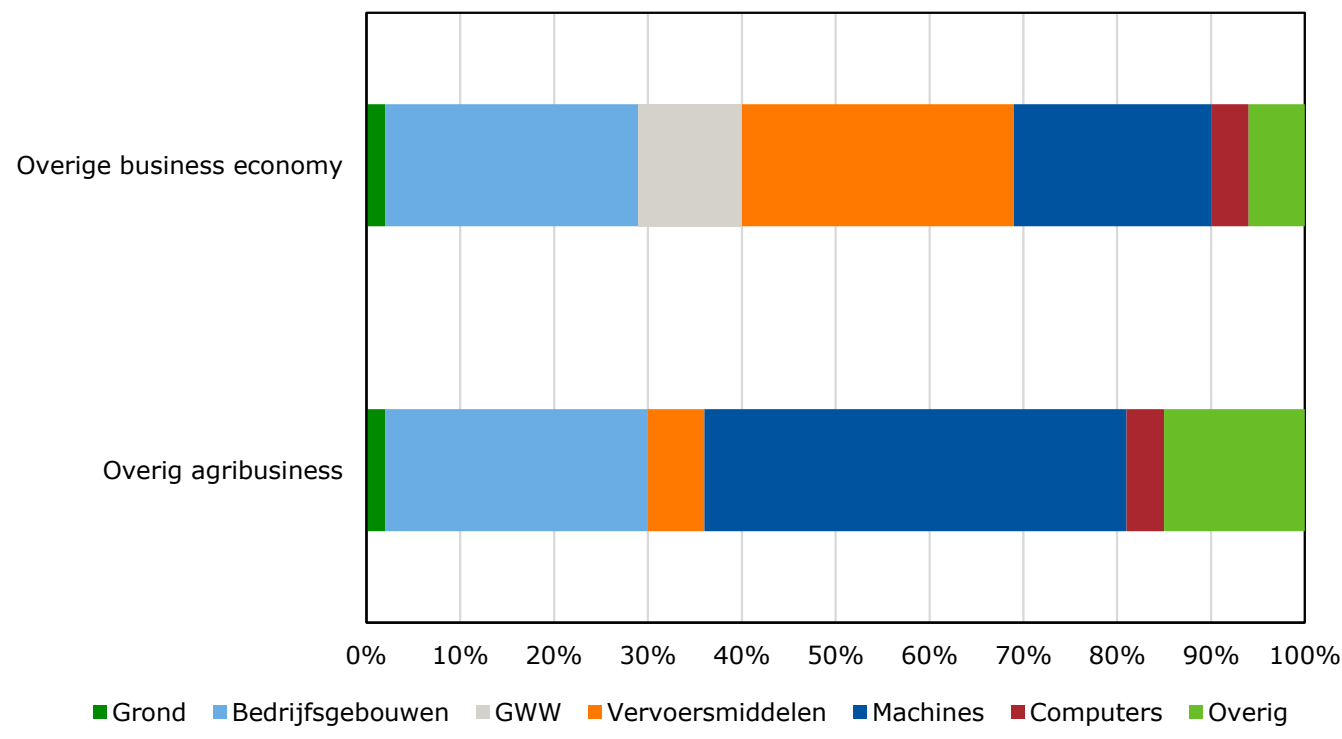

Figuur 5.20 Investeringen in materiële vaste activa, niet-financiële bedrijfsleven en overig agribusiness, naar categorie, 2019

Bron: CBS. 


\section{$6.1 \quad$ Inleiding}

In dit hoofdstuk komt de relatie van de (primaire) landbouwsector met de bredere leefomgeving aan de orde. Paragraaf 6.2 gaat in op economische en ecologische prestaties van de Nederlandse landbouwsector ${ }^{57}$ bekeken aan de hand van langetermijntrends, kortetermijntrends en vergelijkingen met andere EU-landen. Daarbij is er speciale aandacht voor de Sustainable Development Goals die grote raakvlakken hebben met de landbouwsector. ${ }^{58}$ In de daarop volgende paragrafen wordt er verder ingegaan op de diverse milieuthema's waar de landbouw invloed op heeft: gewasbescherming en plantgezondheid (paragraaf 6.3), broeikasgasemissies (paragraaf 6.4), fijnstof (paragraaf 6.5), fosfaat- en stikstofproductie (paragraaf 6.6) en ammoniak (paragraaf 6.7).

Paragraaf 6.8 gaat in op dierenwelzijn en diergezondheid, inclusief het gebruik van antibiotica. Paragraaf 6.9 ten slotte geeft een beschouwing over agrarisch natuurbeheer en biodiversiteit.

\subsection{Economische en ecologische prestaties}

\subsubsection{Algemeen}

De Nederlandse landbouwsector staat nu en in de toekomst voor grote uitdagingen op het gebied van duurzaamheid. Nederland wil voorop lopen in het creëren van een duurzamere landbouw en wil een wereldwijde koploper worden als het gaat om de inzet van kringlooplandbouw (Rijksoverheid, 2019). Daarmee gaat het om het effectief verbinden van de ketens van akkerbouw en veehouderij waardoor reststromen van de ene keten een grondstof zijn voor de andere keten (WUR, 2019). Daarbij worden mest en voedselresten niet gezien als een probleem, maar juist als een belangrijke bouwsteen binnen een effectieve kringlooplandbouw. Produceren met zo min mogelijk verlies aan grondstoffen en een zorgvuldig beheer van bodem, water en natuur is de kern van kringlooplandbouw. Voor een duurzaam landbouwsysteem is het nodig de hele voedselproductieketen integraal te benaderen: van de manier waarop voedingsstoffen worden gebruikt, hoe er wordt geteeld, het voedsel dat de leverancier ervan maakt, tot wat de consument met het eten doet. $\mathrm{Er}$ is namelijk een sterke verbinding van landbouw en de effecten op natuur en biodiversiteit (RIVM, 2019).

In deze paragraaf worden de economische en ecologische prestaties van de Nederlandse landbouwsector ${ }^{59}$ bekeken aan de hand van langetermijntrends, kortetermijntrends en vergelijkingen met andere EU-landen. Daarbij is er speciale aandacht voor de Sustainable Development Goals die grote raakvlakken hebben met de landbouwsector. De Sustainable Development Goals (SDG's) zijn in 2015 opgesteld door de Verenigde Naties (VN), zijn door 193 landen ondertekend en lopen tot 2030 (VN, 2015). Hiermee streven alle lidstaten van de VN naar een duurzame toekomst. Specifiek wordt in de resolutie aandacht geschonken aan de bestrijding van ongelijkheden tussen en binnen landen, gendergelijkheid, mensenrechten en de langdurige bescherming van de planeet en haar natuurlijke bronnen. De SDG's sluiten goed aan bij het streven naar een stijgende brede welvaart en het tegelijkertijd beschermen van de planeet tegen klimaatverandering. Brede welvaart betreft de kwaliteit van leven hier en nu en de mate waarin deze al dan niet ten koste gaat van die van

\footnotetext{
${ }^{57}$ Voor de langetermijntrends gaat het in de meeste gevallen over ontwikkelingen in de primaire landbouw, inclusief bosbouw en visserij (sector A). In het geval van de IPCC-emissies, mestproductie en biologische landbouwbedrijven gaat het enkel over de primaire landbouw.

${ }^{58}$ De cijfers in deze paragraaf kunnen afwijken van de cijfers in paragraaf 6.3 tot en met 6.7 vanwege andere bronnen en daarmee een andere afbakening.

${ }^{59}$ Voor de langetermijntrends gaat het in de meeste gevallen over ontwikkelingen in de primaire landbouw, inclusief bosbouw en visserij (sector A). In het geval van de IPCC-emissies, mestproductie en biologische landbouwbedrijven gaat het enkel over de primaire landbouw.
} 
latere generaties en/of van die van mensen elders in de wereld (CBS, 2020b). Op verzoek van de Tweede Kamer heeft het kabinet in 2017 het CBS gevraagd een brede welvaartsmonitor te ontwikkelen (CBS, 2017c). Het doel van deze Monitor 'Brede Welvaart \& de Sustainable Development Goals' is om politiek en maatschappelijk inzicht te verschaffen in de brede welvaart in Nederland, én om de stand van zaken te geven over de voortgang richting het behalen van de 17 SDG's in Nederland. Er wordt daarbij gekeken naar de brede welvaart hier en nu, maar ook naar het effect van onze huidige welvaart op de volgende generaties in Nederland ('brede welvaart later') en het effect van ons handelen op de brede welvaart in andere landen ('brede welvaart elders').

De landbouwsector heeft sinds 1995 sterke vooruitgang geboekt op duurzaamheidsgebied, maar een belangrijke nuance daarbij is dat de meeste verduurzaming in de jaren negentig en het eerste decennium van de $21^{\text {ste }}$ eeuw heeft plaatsgevonden. Vooral ook daarom is het goed om te kijken naar kortetermijntrends. Bovendien wil een positieve ontwikkeling nog niet zeggen dat er al een acceptabel niveau bereikt is. Een EU-vergelijking kan daarbij aanvullende inzichten verschaffen. De SDG's van de Verenigde Naties zijn een krachtig beleidskader om de Nederlandse prestaties af te zetten tegen de prestaties in andere landen en de kortetermijntrends te monitoren.

\subsubsection{Langetermijntrends}

Kringlooplandbouw is volgens Wageningen University \& Research (WUR) een 'ontwikkelrichting om voldoende voedsel te kunnen produceren op een manier die de aarde en de natuur aankunnen. Met minder 'externe input' zoals kunstmest, gewasbeschermingsmiddelen en fossiele brandstoffen, maar met maximale benutting van grondstoffen, eind- en bijproducten en reststromen. En dit met een zo laag mogelijke uitstoot van milieubelastende stoffen' (WUR, 2020a).

In de publicatie De Nederlandse agrarische sector in internationaal verband (Jukema et al., 2020) is nauwgezet gekeken naar de economische en duurzaamheidsprestaties van de primaire agrarische sector sinds 1995. Er werd getoond dat een flinke groei van de productie gepaard ging met een aanzienlijke verduurzaming. Zo is de milieu-, energie- en grondstoffenproductiviteit substantieel verbeterd, zijn er grote stappen gezet in de reductie van luchtvervuiling en in het gebruik van grondstoffen, energie en water. In deze paragraaf worden de cijfers van de publicatie van 2020 zo veel mogelijk geactualiseerd.

Tussen 1995 en 2020 groeide de toegevoegde waarde van de primaire landbouw gecorrigeerd voor prijseffecten met $32 \%$ en tegelijk daalde de werkgelegenheid met $14 \%$ (CBS $2021 \mathrm{j}$ en k). Het energiegebruik als input voor de landbouwproductie daalde met $16 \%$ in deze periode, wat leidde tot een stijging van de energieproductiviteit met bijna 50\% (CBS, 2021I). Ook namen de emissies van broeikasgassen (kooldioxide, lachgas en methaan) en van verzurende stoffen (met name ammoniak) tot en met 2019 naar de lucht af met respectievelijk 17 en 48\% (CBS, 2021m). De agrarische sector levert in toenemende mate diensten (zowel agrarisch als niet-agrarisch) en dit beïnvloedt de duurzaamheidsprestaties positief. Per eenheid output daalt hiermee namelijk de input van grondstoffen en emissies. Deze forse afname van inputs en emissies per verdiende euro draagt autonoom bij aan de prestatie-indicatoren voor duurzaamheid (oftewel brede welvaart).

\section{Uitstoot broeikasgassen}

De bijdrage van de landbouw aan de totale broeikasgasuitstoot (in $\mathrm{CO}_{2}$-equivalenten) was in $202015,9 \%$ (CBS, 2021n). Het ging in 2020 om een equivalent van ruim $26 \mathrm{mln}$. ton $\mathrm{CO}_{2}$ aan broeikasgassen $\left(\mathrm{CO}_{2}\right.$, lachgas en methaan). Bij de reductie van de uitstoot van lachgas zijn de grootste successen geboekt sinds 1995 wat te maken heeft met de verminderde toepassing van (kunst)mest, verbeterde efficiency en minder stikstoflekken. Methaanuitstoot (vooral uit de pens van koeien) is moeilijker te reduceren en hangt vooral samen met dieraantallen. De uitstoot van $\mathrm{CO}_{2}$ is iets verminderd en hangt samen met het aardgasverbruik in de tuinbouw en het brandstofverbruik door landbouwvoertuigen en -werktuigen. Tussen 1995 en 2018 is de broeikasgasuitstoot met $17 \%$ afgenomen en dat resulteert (met een toegenomen toegevoegde waarde van $32 \%$ ) in een hogere broeikasgasproductiviteit van bijna 50\% (CBS, 2021m). Daarbij dient te worden opgemerkt dat de duurzaamheidswinst (minder dieren, minder energiegebruik) is geboekt in de periode 1995-2005 en niet daarna. 


\section{Uitstoot verzurende stoffen}

In 2019 werd voor 7,5 mld. zuur-equivalenten (CBS, 2021m) aan verzurende stoffen (stikstofoxiden, zwaveloxiden en ammoniak) uitgestoten. De afgeleide emissies van verzurende stoffen zijn sinds 1995 met $48 \%$ afgenomen (met een lichte stijging sinds 2012). Ammoniak is met afstand de belangrijkste verzurende stof en de afname in dezelfde periode was hier identiek. De grootste bijdrage komt uit stallen en mestopslag en bij het uitrijden van mest. Grofweg de helft komt van rundvee en de rest vooral van overig vee en kunstmest. De sterke afname is vooral het gevolg van een krimpende veestapel, eiwitarmer voer, emissiearme stallen, afdekken van mestopslag-voorzieningen en (vooral) emissiearm bemesten. Voor specifiek stikstofoxiden geldt dat de emissies door landbouw, bosbouw en visserij in de gehele periode sinds 1995 met 44\% (CBS, 2021m) zijn gedaald door vooral het stellen van strengere eisen (euronormen) aan landbouwtrekkers, machines en voertuigen. De uitstoot van zwaveldioxide is met 94\% (CBS, 2021m) afgenomen door vooral de verlaging van het zwavelgehalte in motorbrandstoffen.

\section{Gebruik van grondstoffen, energie en water}

Sinds 1995 is het energieverbruik in de Nederlandse landbouw, bosbouw en visserij met 14\% afgenomen (CBS, 2021I). De glastuinbouw is veruit de grootste energiegebruiker. ${ }^{60}$ Het gebruik van leidingwater (halvering sinds 1995) is ook sterk afgenomen, maar de grootste winst zat ook hier in de periode 19952000. Het gebruik van grondwater nam tussen 1995 en 2016 met maar liefst $70 \%$ af, maar nam daarna sterk toe en zat in 2019 al weer op het niveau van 1995 (CBS, 20210 en Jukema et al., 2020). Beregening en het drenken van vee vragen het meeste water en sinds 2012 zijn de dieraantallen weer licht toegenomen. Bovendien is er deels door klimaatverandering steeds meer sprake van droge groeiseizoenen.

\section{Uitstoot van stikstof- en fosfaatverbindingen}

Nutriënten zoals stikstof en fosfaat zijn belangrijk voor de productie van gewassen in de land- en tuinbouw. Dit kan in de vorm van dierlijke mest of kustmest worden toegepast. In het kader van kringlooplandbouw is het van belang om dierlijke mest zo effectief mogelijk te gebruiken en het gebruik van kunstmest te reduceren. De mestproductie is sinds 1995 gedaald met een kleine 10\% (CBS, 2021p). Het mestoverschot is fors afgenomen door veel minder aanvoer (bijna halvering fosfaat) en praktisch gelijkblijvende afvoer (zoals export). Voor fosfaat is het overschot zelfs nagenoeg verdwenen.

\subsubsection{Bijdragen aan Sustainable Development Goals}

Voor de bespreking van kortetermijntrends en EU-vergelijkingen wordt de blik gericht op de Sustainable Development Goals (SDG's).

Tabel 6.1 toont de doelen waarbij er tot op zekere hoogte raakvlakken zijn met de themagebieden landbouw, natuur en voeding (zie verder Monitor Brede Welvaart \& SDG's editie 2021: CBS, 2021h). Daarbij is het interessant om te zien hoe Nederland presteert ten opzichte van de andere EU-landen en hoe Nederland zich heeft ontwikkeld door de tijd. Voor de meeste doelen is de trend van de indicatoren binnen de doelen voor de afgelopen zeven jaar overwegend positief geweest. Alleen voor goede gezondheid en welzijn, leven op het land (achteruitgang) en leven op het water (stabilisatie) is dat niet zo.

Indien de Nederlandse prestaties worden vergeleken met andere EU-landen dan is het beeld wisselend. Op economisch vlak en wat betreft verantwoorde consumptie en productie of goede gezondheid en welzijn zijn de Nederlandse resultaten bovengemiddeld goed. Op de overige gebieden zijn de prestaties ondergemiddeld tot gemiddeld. Zo kent Nederland het hoogste aantal dieren per inwoner. Deze hoge veedichtheid zorgt voor grote overschotten aan mest. Ook het aandeel biologische landbouw ${ }^{61}$ in Nederland is een van de laagste van Europa. Nederlanders verspillen thuis veel voedsel (34 kilo per persoon in 2019), maar er is wel een positieve ontwikkeling: 7 kilo minder dan in 2016, ${ }^{62}$ (Voedingscentrum, 2019). Op het gebied van

60 Het hoge energieverbruik in de glastuinbouw maakt de sector zeer gevoelig voor stijgingen van de gasprijs zoals deze zich nu voordoen. Bedrijven met (deels) variabele energiecontracten kunnen in de financiële problemen komen en kiezen soms voor lege kassen (FD, 2021).

${ }^{61}$ Daarbij dient te worden opgemerkt dat biologische landbouw niet synoniem is met duurzamere landbouw, er zijn ook andere vormen van duurzamere landbouw.

62 Bovendien is de voedselverspilling net iets lager dan het gemiddelde van elf onderzochte EU-landen. De verspilling door Nederlandse huishoudens zit (per persoon per jaar) hoger dan in Estland, Oostenrijk, Finland, Duitsland en Ierland en lager dan in Denemarken, Luxemburg, Malta, Zweden en het Verenigd Koninkrijk (Fusions, 2016). 


\section{- Veedichtheid}

Nederland heeft de hoogste veedichtheid van alle EU-landen volgens de laatste internationale vergelijking in 2016. In 2020 ging het om 3,48 grootvee-eenheden per hectare landbouwgrond.

\section{- Biologische landbouw}

Nederland heeft met 3,8\% biologische landbouw in het totaal van landbouwgrond een 22e positie in de EU. Het aantal biologisch gecertificeerde landbouwbedrijven is vertoont sinds 2015 een stijgende trend (zie ook paragraaf 4.4). Niet enkel het aantal biologische gecertificeerde landbouwbedrijven is toegenomen, ook de oppervlakte biologisch gecertificeerde landbouw is de laatste jaren sterk gegroeid (+43\% in 2020 ten opzichte van 2015) (CBS, 2021g).

- Eiwitrijke gewassen Nederland heeft relatief weinig eiwitrijke gewassen met 0,5\% van het totaal aan landbouwgrond in 2020. Van de 22 vergeleken EU-landen heeft Nederland een 18 e positie.

\section{Leven op het land (SDG 15)}

Dit doel betreft bescherming, herstel en duurzaam beheer van alle vormen van leven op het land. Gezonde ecosystemen staan aan de basis van schoon water, schone lucht, de aanwezigheid van insecten voor bestuiving of de mogelijkheden voor ontspanning en recreatie. Als ecosystemen eenmaal verwoest zijn dan kan de schade onherstelbaar zijn.

Het beleid voor dit doel wordt vooral gemaakt door de ministeries I en W en LNV en de gemeten indicatoren hebben een redelijk sterke link met landbouw, natuur en voeding. Dat is de reden dat dit doel, net als SDG 2, uitvoeriger zal worden bekeken.

Zoals eerder getoond is bij dit doel de ontwikkeling van de indicatoren door de tijd sterk negatief. Daarnaast scoort Nederland voor dit doel iets onder het EU-gemiddelde:

- Overheidsuitgaven aan milieubescherming

In 2019 hadden de Nederlandse overheidsuitgaven aan milieubescherming een omvang van 1,4\% van het bbp. Dat was het op een na hoogste percentage van 24 onderzochte EU-landen.

- Totale milieu-uitgaven

De totale milieu-uitgaven waren in 2020 2,3\% van het bbp. In 2017 was Nederland 4e van 25 onderzochte EU-landen.

- Vogels boerenland

In 2019 was de vogelindex (aantal, verspreiding) 60,7 in Nederland (met 2000=100). In vergelijking met andere EU-landen neemt Nederland met deze indicator een middenpositie in: $9^{\mathrm{e}}$ van 19 onderzochte EUlanden in 2017.

- Milieuproblemen

In 2020 ervoer 14,2\% van de 16+ bevolking milieuproblemen. In 2019 was Nederland $18^{\mathrm{e}}$ van 27 EUlanden.

- Fosfaatoverschot

In Nederland bedroeg het overschot gemiddeld 1,2 kilogram fosfaat per hectare landbouwgrond in 2020. In 2017 was Nederland $12^{\mathrm{e}}$ van 18 onderzochte EU-landen.

- Stikstofoverschot In_Nederland was het overschot gemiddeld 176,4 kilogram stikstof per hectare landbouwgrond in 2020. In 2017 was Nederland laatste van 19 onderzochte EU-landen.

- Beschikbare ruimte De beschikbare ruimte per Nederlander was in $20202.387 \mathrm{~m}^{2}$. Nederland was in 2018 op dit punt $26^{\mathrm{e}}$ van 27 EU-landen.

- Natuur- en bosgebieden

In 2015 bestond 14,8\% van Nederland uit natuur- en bosgebieden en daarmee is het laatste binnen de EU.

\section{SDG's en Natuurlijk kapitaalrekeningen}

De natuur levert grondstoffen en voedsel, reguleert ons klimaat en zuivert lucht en water. Ook biedt ze ons een prettige leefomgeving om in te wonen en recreëren. Deze prestaties verrekenen we niet in de prijzen van producten. Een vrij nieuwe en door de VN erkende methode voor het meten van de bijdrage van natuur aan de economie en het uiteindelijk bevorderen van duurzaam beheer van natuurlijke hulpbronnen, kan hier verandering in brengen (Hein, 2021; De Jongh et al., 2021). 
De zogenaamde 'natural capital accounting' is een nieuwe bron van informatie voor het ontwikkelen en implementeren van beleid voor onder meer het behalen van de SDG's (Ruijs et al., 2018). De internationaal geaccepteerde meetstandaard van 'natural capital accounting' betreft het 'System of Environmental Economic Accounting - Ecosystem Accounting' (SEEA EA). Deze standaard is in Nederland bekend onder de naam 'Natuurlijk Kapitaalrekeningen' (NKR). Het is een raamwerk van meetmethoden dat diensten van de natuur in kaart brengt en als doel heeft om de relatie tussen natuur, economie en menselijke activiteiten op overzichtelijke en internationaal vergelijkbare wijze in kaart te brengen. De NKR bieden onder andere mogelijkheden om de SDG's beter in beeld te brengen (Hein, 2021; De Jongh et al., 2021).

In Nederland worden dertien ecosysteemdiensten onderscheiden, onder meer drinkwater-, voedsel- en houtproductie, recreatie en natuurtoerisme, luchtzuivering, regulering van waterhuishouding en klimaat, fijnstofafvanging door vegetatie, en koolstofvastlegging (De Jongh et al., 2021). Ook een aantal voor de landbouw potentieel belangrijke ecosysteemdiensten worden meegenomen, zoals de bestuiving door wilde hommels en bijen van bijvoorbeeld boomgaarden en andere bestuivingsafhankelijke tuinbouwgewassen. Daarnaast wordt ook de bijdrage van landbouwgebieden aan het leveren van ecosystemen gedetailleerd in kaart gebracht, zoals het belang van heggen, hagen en bomenrijen en de bijdrage van de bodem aan landbouwproductie.

\subsection{Gewasbescherming en plantgezondheid}

\subsubsection{Verbruik en milieubelasting}

De afzet van gewasbeschermingsmiddelen schommelde tot 2018 lange tijd rond de $10 \mathrm{mln}$. kilo actieve stof per jaar (figuur 6.1). In 2018 zakte de afzet onder de $10 \mathrm{mln}$. kilo. In 2019 lag de afzet vrijwel op hetzelfde niveau als in 2018. Ruim 40\% van de in 2019 gebruikte middelen is fungicide (schimmelbestrijding) en $30 \%$ herbicide (middelen tegen onkruid, waaronder glyfosaat).

\section{Gunstige weersomstandigheden zorgen voor lager gebruik}

De lente en zomer van het jaar 2019 waren zeer zonnig en droog (KNMI, 2019). Ook 2020 was een droog jaar. Droge warme zomers leiden tot een lager gebruik van fungiciden en herbiciden. Zowel schimmelziekten als onkruiden hebben vocht nodig om zich te ontwikkelen. Daardoor lag in 2019 net als in 2018 de fungicidenafzet lager dan de jaren ervoor. De verkoop van glyfosaat daalde in 2019 met $17 \%$ ten opzichte van 2018. In 2018 werd er een soortgelijke daling genoteerd ten opzichte van 2017. Binnen de land- en tuinbouw wordt ongeveer $50 \%$ van de herbiciden gebruikt in de akkerbouw (Smit et al., 2019). Medio 2022 zal het professioneel gebruik van gewasbeschermingsmiddelen buiten de landbouw op verhardingen en in openbaar groen niet meer toegestaan zijn. Dit heeft invloed op de afzet van met name herbiciden. Van de totale afzet van gewasbeschermingsmiddelen in Nederland is ongeveer $98 \%$ voor gebruik in de land- en tuinbouw. De rest wordt gebruikt door particulieren of door beheerders van het openbaar groen. Het betreft hier vaak onkruidbestrijdingsmiddelen (Compendium, 2014). 


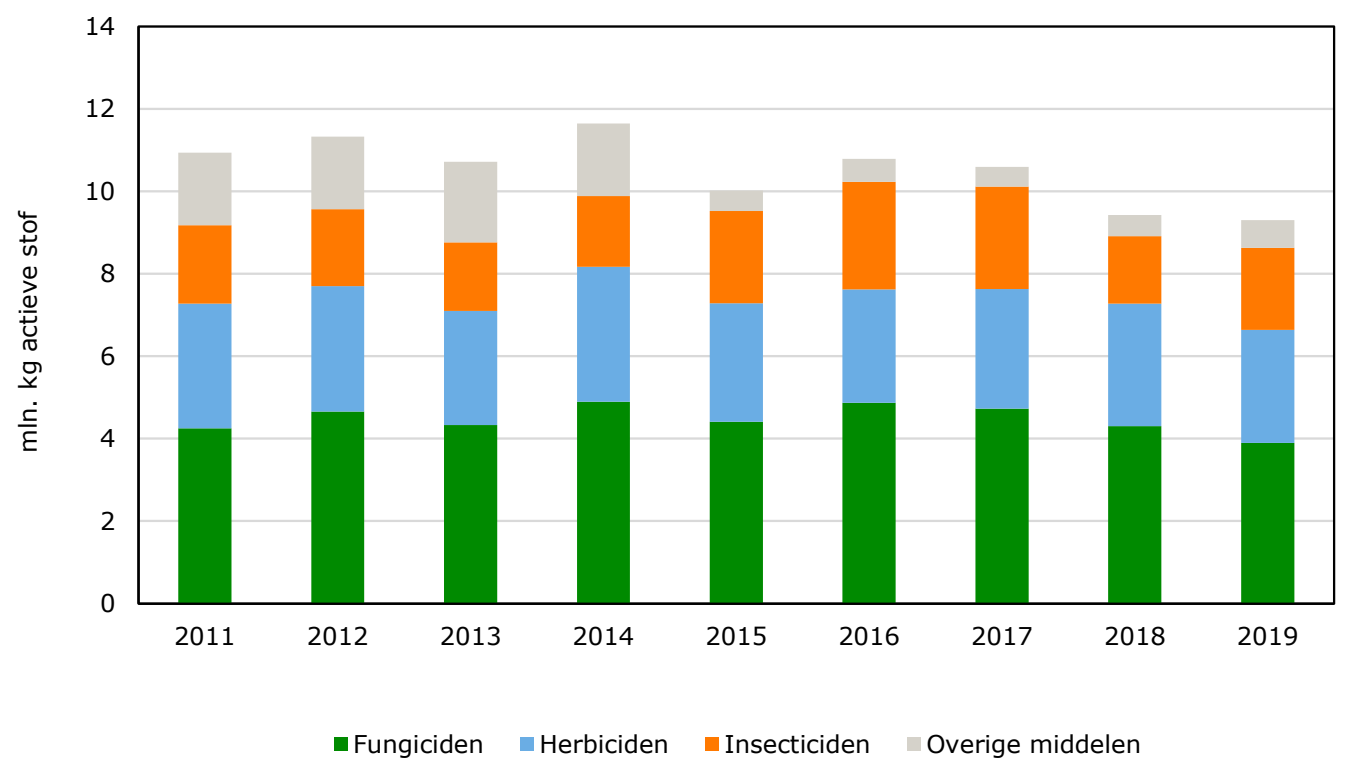

Figuur 6.1 Afzet van gewasbeschermingsmiddelen in de landbouw, naar categorie Bron: CBS, bewerking Wageningen Economic Research.

\section{Milieubelasting}

Naast het actievestofgebruik is de milieubelasting door gewasbescherming een belangrijke indicator. Met name het oppervlaktewater wordt belast door het gebruik van gewasbeschermingsmiddelen. Voor grondwater en bodem is dit duidelijk minder het geval. De totale milieubelasting uit gewasbescherming kende in 2019 een lichte daling ten opzichte van 2018. De milieubelasting naar zowel de bodem als het water daalde.

Over een langere periode bekeken is de totale milieubelasting uit gewasbescherming in de akkerbouw sterk gedaald, namelijk van ruim $4.000 \mathrm{mbp}$ (milieubelastingspunten)/ha in 2002 naar minder dan $2.000 \mathrm{mbp} / \mathrm{ha}$ in de afgelopen jaren. ${ }^{64}$ Met name is de milieubelasting van het oppervlaktewater sterk gedaald, mede door het instellen van teeltvrije zones en het gebruik van driftarme spuitdoppen. In zijn algemeenheid is de milieubelasting sterker gedaald dan het actievestofgebruik, wat betekent dat de gebruikte middelen in de loop van de tijd minder schadelijk zijn geworden voor het milieu.

De milieubelasting uit gewasbescherming in de bloembollenteelt is de laatste jaren stabiel. Na een piek in 2011-2013 (103.000 mbp/ha) ligt het niveau nu op ongeveer $12.000 \mathrm{mbp} / \mathrm{ha}$. Ongeveer tweederde van de milieubelasting vindt plaats naar het oppervlaktewater. De milieubelasting in de fruitteelt in de periode 20172019 (ruim $11.000 \mathrm{mbp} / \mathrm{ha}$ ) is bijna driekwart lager dan in de periode 2006-2008 (41.000 mbp/ha). De laatste jaren is er nog sprake van een lichte daling. Deze ontwikkeling is onder andere te danken aan het gebruik van de tunnelspuit, waardoor middelen minder verwaaien.

\subsubsection{Plantgezondheid}

In de plantaardige sectoren (akkerbouw, groente en fruit, bloemisterij, bloembollen en boomkwekerij en groene ruimte) worden jaarlijks vele import- en exportinspecties uitgevoerd om de verspreiding van met name quarantaine-organismen te voorkomen. Het aantal meldingen van schadelijke organismen was in 2019 vrijwel gelijk aan 2018. Daarnaast zijn er diverse sectorale monitoringsprojecten, waarin specifieke organismen centraal staan, zoals wratziekte bij aardappel en het tomato chlorosis virus (ToCV) in de tuinbouw (MNCP, 2018 en 2019).

In de akkerbouw betroffen de inspecties vooral pootaardappelen, een product dat vanuit Nederland naar veel landen wordt geëxporteerd. Er is voortdurende inspanning nodig om een klein aantal belangrijke

\footnotetext{
${ }^{64}$ De milieubelasting uit gewasbescherming wordt berekend door het verbruik van elk afzonderlijk middel op elk afzonderlijk bedrijf in de Informatienet-steekproef te vermenigvuldigen met de milieubelastingspunten ( $\mathrm{mbp}$ ) volgens de Milieumeetlat van het CLM en vervolgens de milieubelasting met behulp van de wegingsfactoren op te schalen naar de gehele sector en te middelen per ha.
} 
quarantaineorganismen in de (poot)aardappelteelt te bestrijden. Het gaat om aardappelmoeheid (AM), Meloidogyne chitwoodi \& M. fallax, bruinrot, ringrot en wratziekte. Ringrot en wratziekte zijn in 2018 en 2019 niet aangetroffen bij exportcontroles. Wel is bij traceringsonderzoek wratziekte aangetroffen op meerdere bedrijven. Dit heeft geleid tot uitroeiingsacties die doorliepen in 2020 (MNCP, 2018 en 2019). In de bloemisterij betrof een groot aantal van de onderscheppingen het quarantaineorganisme Thaumatotibia leucotreta (Afrikaanse fruitmot), dat sinds 1 januari 2018 wordt gereguleerd. In de bloembollensector waren de twee belangrijkste redenen van afkeur bij export de aanwezigheid van grond en de aanwezigheid van schimmels (met name Fusarium). In grond kunnen zich bodemgebonden organismen bevinden (MNCP, 2018 en 2019).

\subsection{Broeikasgasemissies}

In de zogenaamde Klimaatwet is vastgelegd dat de uitstoot van broeikasgassen (omgerekend naar $\mathrm{CO}_{2}$ equivalenten) in 2030 49\% lager moet zijn dan in 1990, voor 2050 is dit percentage 95; daarnaast moet de Nederlandse staat eind 2020 ten minste 25\% minder broeikasgassen uitstoten ten opzichte van 1990 (Urgenda-arrest).

De Klimaatwet is een uitwerking van het ook door Nederland geratificeerde VN-Klimaatakkoord van Parijs, dat als doel heeft de opwarming van de aarde te beperken tot ruim onder 2 graden Celsius, met een zicht op 1,5 graden Celsius, ten opzichte van het pre-industriële tijdperk. Het akkoord van Parijs is vertaald naar een nationaal Klimaatakkoord, wat nader is uitgewerkt in het Klimaatplan (EZK, 2020). Het Klimaatplan gaat uit van vier hoofdlijnen voor het bereiken van de emissiereductiedoelstellingen in de land- en tuinbouw (EZK, 2020). Het gaat om emissiereductie in de veehouderij, emissiereductie en $\mathrm{CO}_{2}$-opslag door slim landgebruik, verduurzaming van de glastuinbouw en voedselconsumptie en voedselverspilling.

In het Nederlandse Klimaatakkoord is een additionele taakstelling voor 2030 vastgelegd voor de landbouwen landgebruiksectoren. Het gaat om een additionele afname van 3,5 Mton broeikasgasemissies boven op bestaand beleid. Deze 'bijdrage vanuit land- en tuinbouw en natuursectoren is nodig om te kunnen voldoen aan de kabinetsdoelstelling voor Nederland van 49\% reductie en vormt de 'volgende stap' op weg naar 2050' (Klimaatakkoord, p.119). Dit betekent dat voor 2030 de uitstoot door landbouw en landgebruik in 2030 nog maximaal 27,6 Mton $\mathrm{CO}_{2}$-eq. mag bedragen (PBL, 2018). Deze opgave is opgeknipt in een afname van de broeikasgasemissies uit de landbouw (methaan) en glastuinbouw, ieder met respectievelijk ten minste 1 Mton in 2030, en een afname van emissies en verbetering van de klimaatprestatie in landgebruik van 1,5 Mton.

\section{Herkomst van broeikasgassen}

De emissie van koolstofdioxide $\left(\mathrm{CO}_{2}\right)$ is vooral afkomstig van de verbranding van fossiele brandstoffen. De glastuinbouw heeft hier een belangrijk aandeel in. De emissie van de overige broeikasgassen is vooral afkomstig uit de veehouderij. Methaanemissie vindt hoofdzakelijk plaats bij de pens- en darmfermentatie van graasdieren en bij de opslag van dierlijke mest. Emissie van lachgas vindt plaats bij de opslag van mest, maar ook bij beweiding en de toediening van mest en kunstmest. Het gaat om directe emissies vanuit de bodem naar de lucht en indirecte emissies die ontstaan bij de depositie van ammoniak en bij de uit- en afspoeling van stikstof naar grond- en oppervlaktewater.

Wat betreft methaan is recent door het IPCC geconcludeerd dat methaan in landbouwkringlopen een andere bijdrage heeft aan de opwarming van de aarde dan methaan uit fossiele brandstoffen (IPCC, 2021). Methaan en andere broeikasgassen uit de landbouw behoren tot de zogenaamde kort-cyclische koolstofkringloop (waar sprake is van voortdurende omzetting van koolstof), in tegenstelling tot het vrijkomen van broeikasgassen bij het verbranden van fossiele brandstoffen die alle tot de lang-cyclische koolstofkringloop behoren (waar sprake is van toevoeging van koolstof). Uitstoot door de landbouw zit dan in het gebruik van fossiele energie (voor productie van kunstmest bijvoorbeeld of transport) en in verandering van de veestapel en het grondgebruik. 


\section{Reductie van broeikasgassen}

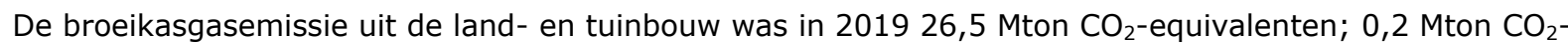
equivalenten lager dan in 2018 (figuur 6.2). De broeikasgasemissie uit de land- en tuinbouw is ten opzichte van 1990 met $18 \%$ gedaald.

Voor het jaar 2020 geldt volgens het Convenant Schone en Zuinige Agrosectoren uit 2008 de doelstelling om de $\mathrm{CO}_{2}$-emissie met 3,5 Mton te reduceren (45\%) ten opzichte van 1990 en de emissie van methaan en lachgas met 4-6 Mton $\mathrm{CO}_{2}$-equivalenten (15-23\%). Bij methaan en lachgas is dat doel in 2019 ongeveer bereikt. Voor $\mathrm{CO}_{2}$ is het doel, met nauwelijks een reductie tussen 1990 en 2019, nog niet bereikt.

De totale $\mathrm{CO}_{2}$-emissie van de landbouw was in 2019 vrijwel gelijk aan die van 1990. Ten opzichte van de piek in 2010 bedraagt de reductie in 2019 20\%. Het totaal energiegebruik van de glastuinbouw liet in de periode 2010 tot en met 2014 een dalende trend zien, in de periode $2015 \mathrm{t} / \mathrm{m} 2018$ bleef het min of meer stabiel en in de periode 2019 tot en met 2020 nam het toe (Smit en Velden, 2021). (In 2019 is een reductie van de emissie van lachgas van 4,1 Mton $\mathrm{CO}_{2}$-equivalenten bereikt ten opzichte van 1990 . Dit is vooral het gevolg van een afname van het gebruik van dierlijke mest en kunstmest. De methaanemissie daalde ten opzichte van 1990 met 1,7 Mton $\mathrm{CO}_{2}$-equivalenten, wat vooral is toe te schrijven aan een afname van het aantal runderen tussen 1990 en 2019.

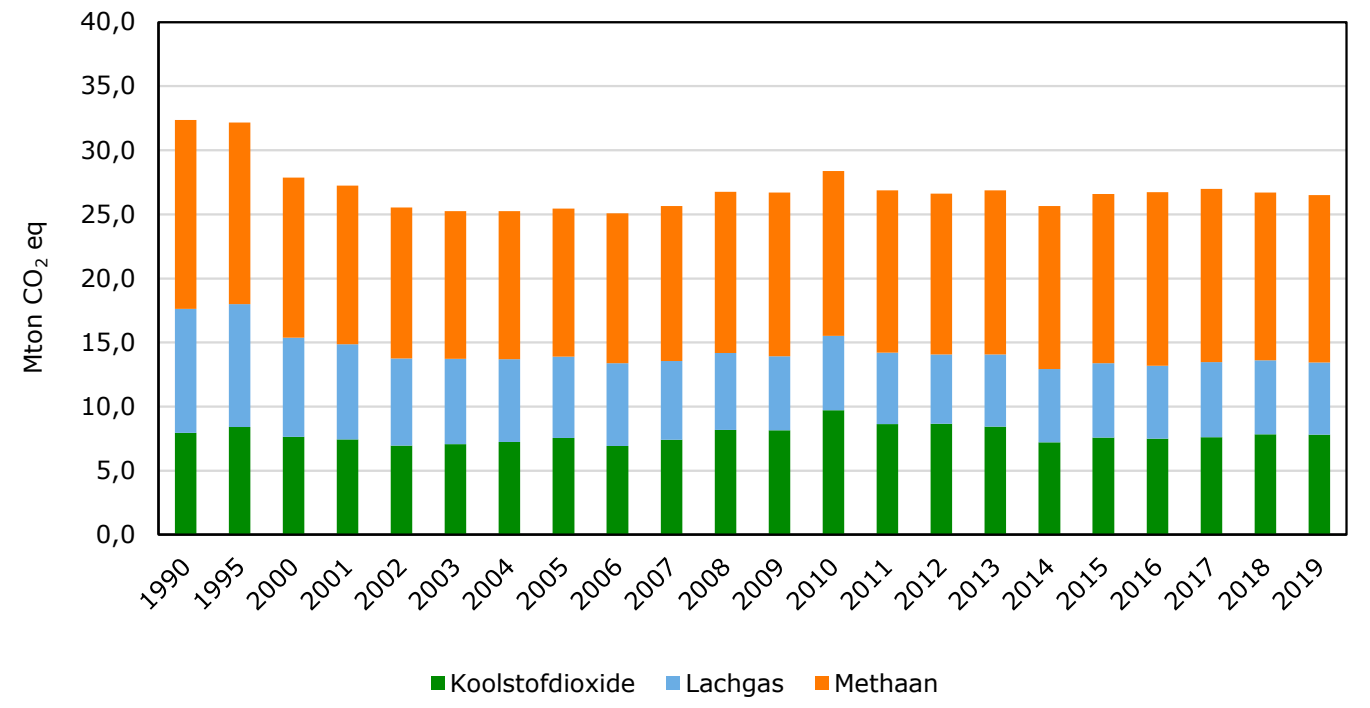

Figuur 6.2 Broeikasgasemissie in de landbouw, 1990-2019

Het aandeel van de land- en tuinbouw in de totale broeikasgasemissies in Nederland is tussen 1990 en 2005 gedaald van 18 naar 14\%, om vervolgens weer te stijgen naar 18 à $19 \%$ in de laatste paar jaar.

Het aandeel in de land- en tuinbouwemissies dat afkomstig is van methaan is gestegen van $45 \%$ in de 90 -er jaren naar $50 \%$ in het afgelopen decennium. Het aandeel lachgas is gedaald van rond de $30 \%$ in de jaren negentig naar 21 à $22 \%$ in de laatste jaren. Het aandeel broeikasgas afkomstig van $\mathrm{CO}_{2}$ is gestegen van $25 \%$ in 1990 naar bijna 30\% in de laatste jaren. Het jaar 2010 vertoont hierin een piek met een aandeel van $34 \%$. De oorzaak daarvan was de toename van het aantal warmtekrachtinstallaties in de glastuinbouw tussen 2006 en 2010.

\subsubsection{Glastuinbouw}

De Nederlandse glastuinbouw en de Nederlandse overheid hebben in 2014 de Meerjarenafspraak Energietransitie Glastuinbouw 2014-2020 gemaakt. Deze afspraak geldt in combinatie met het Convenant $\mathrm{CO}_{2}$-emissieruimte binnen het $\mathrm{CO}_{2}$-sectorsysteem glastuinbouw. In beide convenanten staat de $\mathrm{CO}_{2}$-emissie

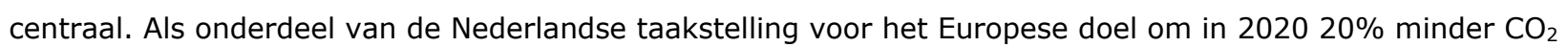


uit te stoten in vergelijking met 1990, was het $\mathrm{CO}_{2}$-emissiedoel voor de Nederlandse glastuinbouw bepaald op 6,2 Mton in 2020. Na de technische correctie voor mutaties van het areaal en de verkoop van elektriciteit, is in 2017 het doel aangepast naar 4,6 Mton. In de periode na deze correctie is duidelijk geworden dat een nieuwe technische correctie relevant is (Van der Velden en Smit, 2020)(LNV, 2021). Hierover is echter door de convenantspartijen nog geen besluit genomen. Hierdoor is geen antwoord te geven op de vraag of de glastuinbouw het doel voor 2020 gerealiseerd heeft (Smit en van der Velden, 2021).

In 2020 steeg de totale $\mathrm{CO}_{2}$-emissie van de glastuinbouw naar 6,1 Mton. Er was net als in 2019 een stijging van 0,2 Mton. Hiermee lag de emissie boven het actuele doel na technische correctie uit 2017 (4,6 Mton), maar onder het oorspronkelijke doel uit 2014 (6,2 Mton). De totale $\mathrm{CO}_{2}$-emissie was $11 \%$ lager in vergelijking met 1990 (Smit en van der Velden, 2021).

\subsection{Fijnstof}

Fijnstof, de emissie van zwevend stofdeeltjes naar de lucht, kan leiden tot schadelijke effecten op de gezondheid. Bij fijnstof wordt onderscheid gemaakt in PM10 fijnstof en in PM2,5 fijnstof, dit is de fijnere fractie.

In het kader van het beleid voor luchtkwaliteit zijn in 1999 door de Europese Unie grenswaarden vastgesteld voor PM10 fijn stof. Voor de fijnere fractie (PM2,5) volgde in 2008 regelgeving. Deze Europese luchtkwaliteitsnormen zijn vertaald in Nederlandse wetgeving (Wet Milieubeheer). In het Nationaal Samenwerkingsprogramma Luchtkwaliteit (NSL) werken het Rijk, de provincies en gemeenten samen om overschrijdingen van de wettelijke grenswaarden op te lossen. Elk jaar wordt de voortgang gerapporteerd. In vrijwel heel Nederland lagen in 2019 de berekende concentraties fijnstof onder de Europese grenswaarden. Plaatselijk zijn er nog enkele overschrijdingen. In verschillende binnensteden komt dit door druk verkeer en op het platteland door veehouderijen. Hierdoor voldoet Nederland nog niet overal aan de Europese grenswaarden. ${ }^{65}$

\section{Bijdrage landbouw}

Van de fijnstofemissie (PM10) in Nederland is $18 \%$ in 2019 afkomstig uit de land- en tuinbouw. Van de fijnstofemissie uit de landbouw is $62 \%$ afkomstig uit de pluimveehouderij (figuur 6.3). De varkenshouderij is de 2 e belangrijke bron van fijnstofemissie met een aandeel van $16 \%$. De totale fijnstofemissie uit de landbouw is gedaald van 6.500 ton in 2015 naar 5.500 ton in 2019.

De pluimveesector is de belangrijkste bron van fijnstof in de land- en tuinbouw. In gebieden met veel pluimveebedrijven zoals de Gelderse Vallei, De Meijerij, het Peelgebied, en delen van Twente is daarom de concentratie van fijnstof relatief hoog ${ }^{66}$. In de pluimveehouderij nam de fijnstofemissie tussen 1995 en 2010 met $70 \%$ toe als gevolg van de overgang van batterijhuisvesting naar grond- en volièrehuisvesting. Vanaf 2012 is er in de EU een verbod op het houden van leghennen in traditionele kooihuisvesting. Door de omschakeling van kooi- naar grondhuisvestingsystemen in de leghennenhouderij, is het aantal strooiselstallen toegenomen (vleeskuikenhouderij in kooien kwam/komt niet voor). Omdat strooiselstallen relatief stofrijk zijn, nam hierdoor de fijnstofuitstoot toe. De daling tussen 2015 en 2019 van de fijnstofemissie met 1.000 ton in de landbouw is vrijwel volledig toe te schrijven aan de pluimveehouderij. Dit is onder andere het gevolg van investeringen in technieken om de uitstoot te verminderen. Voorbeelden daarvan zijn droogtunnels en biofilters.

\footnotetext{
65 https://www.atlasleefomgeving.nl/thema/lucht

66 Zie kaart met regionale verdeling:

https://www.agrimatie.nl/ThemaResultaat.aspx?subpubID=2232\&themaID=2274\&indicatorID=2091
} 


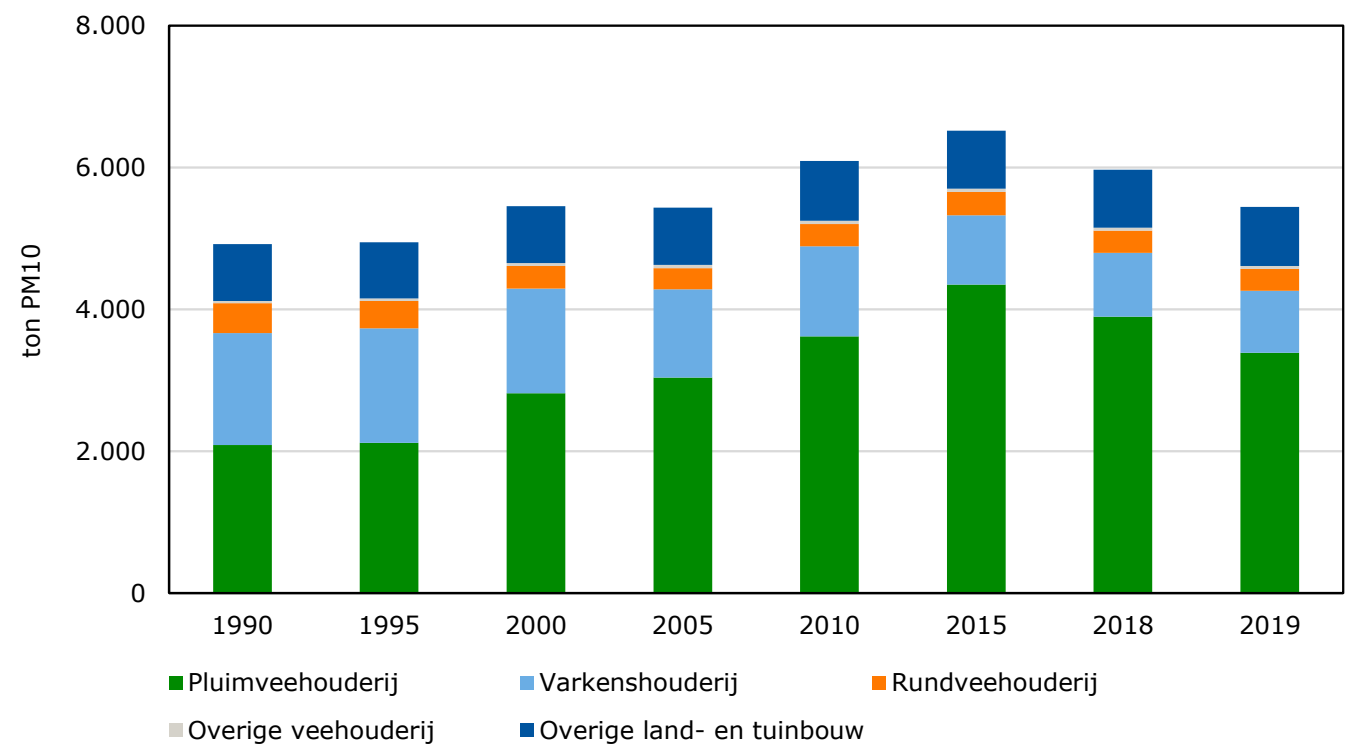

Figuur 6.3 Emissie van fijnstof uit de land- en tuinbouw naar herkomst

In de rundveehouderij is de fijnstofemissie tussen 1990 en 2005 met bijna 30\% gedaald. De daling was met name het gevolg van een afname van het aantal dieren en van een afname van beweiding. Tussen 2005 en 2015 steeg de emissie met 10\% door een toename van het aantal dieren. Deze stijging is in 2019 grotendeels weer ongedaan gemaakt doordat het aantal dieren afnam. De fijnstofemissie is daardoor in 2019 $8 \%$ lager dan in 2015.

In de varkenshouderij daalde de fijnstofemissie in de periode 1990-2015 met bijna 40\%. Deze daling vond vooral na 2005 plaats. De belangrijkste reden is een toename van het gebruik van luchtwassers in varkensstallen. Door meer luchtwassers zet de daling in de varkenshouderij na 2015 door. In 2019 is de fijnstofemissie $10 \%$ lager dan in 2015 .

De fijnstofemissies van overige bronnen uit de landbouw zijn vrijwel constant. Het betreft voornamelijk emissies die plaatsvinden bij het lossen, laden en aanwenden van kunstmest, het lossen van krachtvoer en het toedienen van gewasbeschermingsmiddelen. De fijnstofemissie bij het oogsten van hooi en akkerbouwgewassen is met ruim $15 \%$ gedaald doordat er minder wordt gehooid.

\subsection{Fosfaat- en stikstofproductie}

De Europese Unie heeft zowel voor stikstof als fosfaat een plafond vastgesteld voor de excretie van stikstof en fosfaat. Het instellen van fosfaat- en stikstofplafonds was een voorwaarde van de EU om Nederland vanaf 2006 derogatie te verstrekken voor de gebruiksnorm dierlijke mest van $170 \mathrm{~kg}$ stikstof per ha. Door de derogatie mogen bedrijven met meer dan $80 \%$ grasland 250 of $230 \mathrm{~kg}$ stikstof uit dierlijke mest per ha bemesten.

In 2016 zijn de EU-fosfaat- en stikstofplafonds ten behoeve van het Nederlandse beleid vertaald naar sectorplafonds voor melkvee, varkens en pluimvee.

Het nationale fosfaatplafond is $172,9 \mathrm{mln}$. $\mathrm{kg}$ fosfaat. Voor melkvee is het sectorplafond $84,9 \mathrm{mln}$. $\mathrm{kg}$ fosfaat. De sectorplafonds fosfaat voor varkens en pluimvee zijn 39,7 respectievelijk $27,4 \mathrm{mln}$. $\mathrm{kg}$ fosfaat.

Het nationale stikstofplafond is $504 \mathrm{mln}$. $\mathrm{kg}$. Voor melkvee is het stikstofplafond $282 \mathrm{mln}$. $\mathrm{kg}$ stikstof. De stikstofplafonds voor varkens en pluimvee zijn 99,1 respectievelijk 60,3 mln. kg stikstof. 
Algemeen beeld fosfaat en stikstof

De hoeveelheid fosfaat in dierlijke mest is in 2020 ruim $22 \mathrm{mln}$. kg lager dan het door de Europese Unie vastgestelde plafond. De stikstofproductie is gelijk aan die van 2019. De afname van de fosfaatproductie is toe te schrijven aan de melkveehouderij (40\%), vleesveehouderij (bijna 25\%) en de pluimveehouderij (ruim $20 \%$ ). Op de melkveehouderij na daalde in alle veehouderijsectoren de stikstofproductie, in totaal met ruim $7 \mathrm{mln}$. $\mathrm{kg}$. Deze daling is vrijwel volledig teniet gedaan door de stijging van de stikstofproductie met bijna $7 \mathrm{mln} . \mathrm{kg}$ in de melkveehouderij.

In 2015 en 2016 overschreed de Nederlandse veehouderij het EU-fosfaatplafond van 172,9 mln. $\mathrm{kg}$ fosfaat en in 2017 het EU-stikstofplafond van 504,4 mln. kg stikstof. Dit was het gevolg van de hogere fosfaat- en stikstofproductie in de melkveehouderij. Om de derogatie te behouden is voor deze sector een fosfaatreductieplan afgesproken. Op basis hiervan moesten de melkveehouderijbedrijven vanaf 2017 zowel het aantal koeien verminderen, als fosfaatarmer voeren om de fosfaat- en stikstofproductie weer onder de EU-plafonds te brengen. Dankzij deze maatregelen is de fosfaatproductie in Nederland in $202013 \%$ lager dan het EU-plafond en de stikstofproductie 3\%.

De levensfase van het dier, de fase in de productiecyclus en het type dier bepaalt de behoefte aan eiwit en fosfaat. De laatste jaren konden gemiddeld lagere fosfaat- en eiwitgehalten in het mengvoer worden gerealiseerd door de eiwit- en fosfaatgehalten in mengvoer beter af te stemmen op de levensfase van het dier, op de fase in de productiecyclus en op het gescheiden mesten van zeugjes en beertjes. Voor melk- en kalfkoeien geldt daarnaast dat betere afstemming van het mengvoer op de eiwit- en fosfaatgehalten in het ruwvoer (die worden beïnvloed door de weersomstandigheden en de stikstofbemesting) heeft bijgedragen aan een verlaagde excretie van stikstof en fosfaat.

\subsubsection{Fosfaat}

Fosfaat en sectorplafond melkvee

Vanaf 2013 steeg de fosfaatproductie van de melkveehouderij naar een top van 92,7 mln. $\mathrm{kg}$ in 2015, gevolgd door een daling naar 78,7 mln. $\mathrm{kg}$ in 2018 en 73,6 mln. $\mathrm{kg}$ in 2020. Het melkveefosfaatplafond van $84,9 \mathrm{mln}$. $\mathrm{kg}$ fosfaat is sinds 2018 niet meer overschreden (figuur 6.4). De stijging van de fosfaatproductie door de melkveehouderij tussen 2012 en 2015 werd voor ongeveer de helft veroorzaakt door hogere fosfaatgehalten in het voer en voor de andere helft door een toename van het aantal dieren. Het verbruikte ruwvoer in 2015 bevatte veel fosfor door de relatief hoge fosforgehalten in kuilvoer van de oogst van 2014 en de relatief hoge fosforgehalten van weidegras in 2015. De daling van de fosfaatproductie door de melkveehouderij in $\mathbf{2 0 1 6}$ was te danken aan lagere fosforgehalten in zowel ruwvoer als mengvoer.

Met het fosfaatreductieplan dat in 2017 is ingevoerd, moesten melkveehouders óf het aantal stuks melkvee verminderen, óf deelnemen aan de stoppersregeling. Daarnaast werd ook het fosforgehalte in het mengvoer verlaagd, om zo beneden het fosfaatplafond uit te komen. Tussen 2016 en 2020 is het aantal melkkoeien met 195.000 stuks gedaald tot 1,55 mln. Het fosforgehalte van mengvoer voor melkvee was in 2015 nog 0,45\%, in 2018 en 2019 is dat gedaald tot 0,42\% en in 2020 weer iets gestegen naar 0,43\%. 


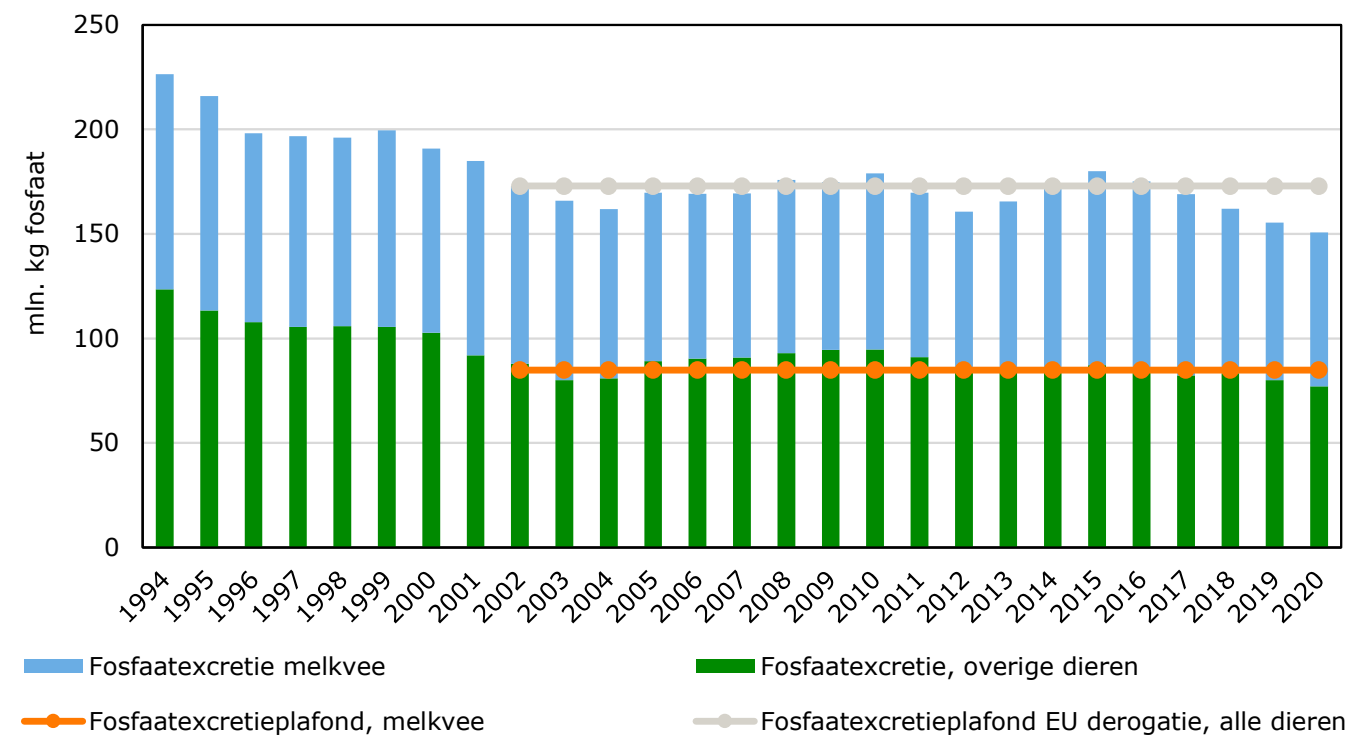

Figuur 6.4 Fosfaatexcretie Nederlandse veestapel, 1994-2020

Bron: CBS, WUM, bewerkt door Wageningen Economic Research.

De fosfaatexcretie van varkens is sinds 2002 geleidelijk aan gedaald van bijna $40 \mathrm{mln}$. $\mathrm{kg}$ naar 36,7 mln. kg in 2020. De reden is zowel minder dieren als minder fosfor in het voer. De fosfaatexcretie van varkensmest zit daarmee bijna $8 \%$ beneden het sectorplafond van $39,7 \mathrm{mln}$. $\mathrm{kg}$. Ook de fosfaatproductie van pluimveemest is gedaald van 27,5 mln. $\mathrm{kg}$ in 2002 naar $24,1 \mathrm{mln}$. $\mathrm{kg}$ in 2020 en ligt hiermee ruim beneden het sectorplafond van $27,4 \mathrm{mln} . \mathrm{kg}$.

\subsubsection{Stikstof}

De stikstofproductie was in 2017 met $512 \mathrm{mln}$. kg voor het eerst hoger dan het plafond. In 2018 is de stikstofproductie van de Nederlandse veestapel gedaald naar $504 \mathrm{mln}$. kg en daarmee exact gelijk aan het plafond. De daling komt voor rekening van de graasdieren. Er zijn minder graasdieren als gevolg van een verlaging van het aantal melk- en kalfkoeien en jongvee door de invoering van het melkveefosfaatquotum in 2018. In zowel 2019 als 2020 was de stikstofproductie met bijna $490 \mathrm{mln}$. kg enkele procenten lager dan het EU-plafond. Naar verwachting zal dit plafond ook in de komende jaren niet worden overschreden, dankzij zowel de opkoopregeling voor de varkenshouderij die in 2021 wordt afgerond als de opkoopregeling voor piekbelasters van veehouderijbedrijven nabij Natura 2000-gebieden, die in november 2020 van start is gegaan.

\section{Stikstof en sectorplafond melkvee}

Het sectorplafond voor de melkveehouderij voor stikstof is $282 \mathrm{mln}$. kg stikstof. Tussen 2006 en 2014 was de stikstofproductie in de melkveehouderij lager dan het plafond (figuur 6.5). Daarna volgde een periode van 4 jaar waarin de stikstofproductie hoger was dan het sectorplafond, met in 2017 als piek een overschrijding van ruim $7 \%$ ( $21 \mathrm{mln}$. kg stikstof). In 2019 is de stikstofproductie tot net onder het sectorplafond gedaald, om in 2020 met een productie van $286,5 \mathrm{mln}$. $\mathrm{kg}$ er net iets boven te zitten. Net als bij de fosfaatproductie werd de stijging van de stikstofproductie tussen 2011 en 2017 veroorzaakt door een combinatie van meer dieren, hogere eiwitgehalten in het ruwvoer en een grotere voederbehoefte door een hogere melkproductie per dier per jaar (Van Bruggen, 2020). 


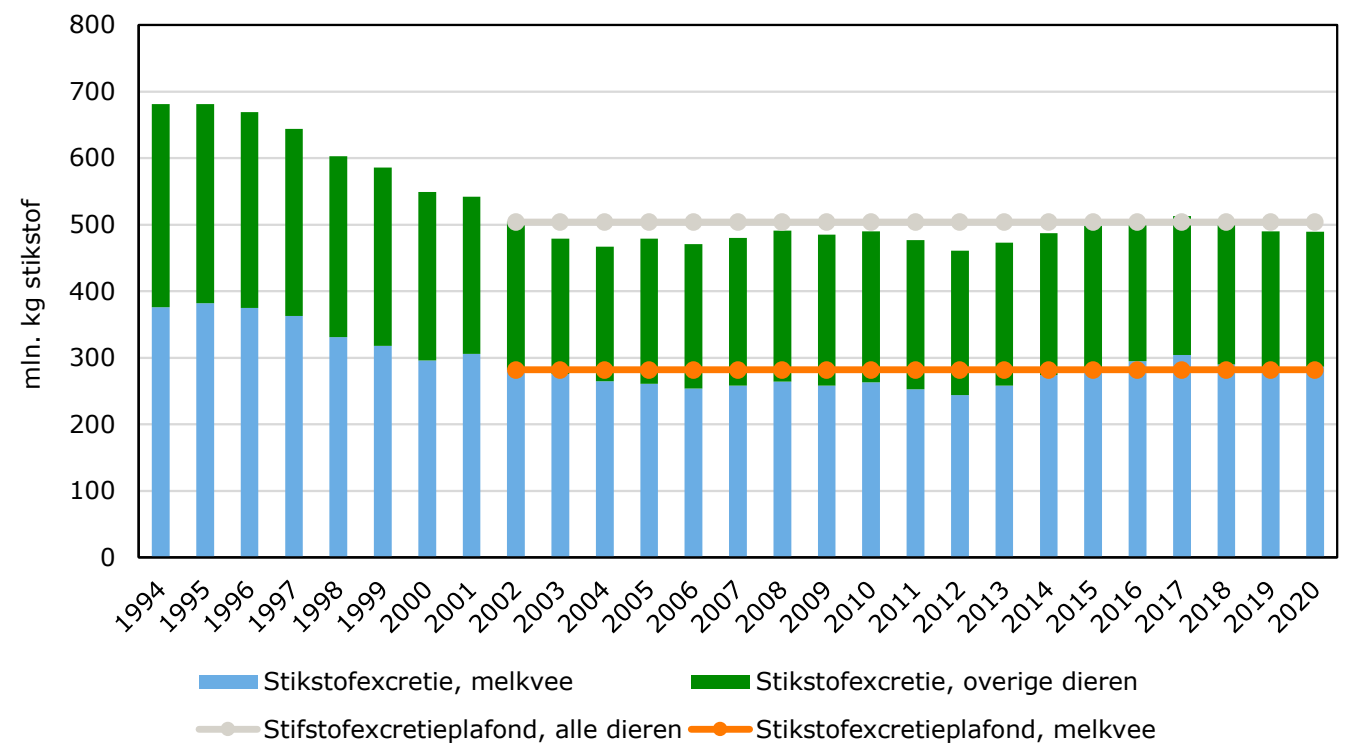

Figuur 6.5 Stikstofexcretie Nederlandse veestapel

Bron: CBS, WUM, bewerkt door Wageningen Economic Research.

De stikstofexcretie van varkens is sinds 2002 geleidelijk aan gedaald van vrijwel $100 \mathrm{mln}$. $\mathrm{kg}$ naar $91,8 \mathrm{mln}$. $\mathrm{kg}$ in 2020. De reden is zowel minder dieren als minder eiwit in het voer. De stikstofexcretie van varkensmest zit daarmee ruim $7 \%$ beneden het sectorplafond van $99,1 \mathrm{mln}$. $\mathrm{kg}$. De stikstofproductie van pluimveemest is gedaald van ruim $60 \mathrm{mln}$. $\mathrm{kg}$ in 2002 naar $54,7 \mathrm{mln} . \mathrm{kg}$ in 2020 en is hiermee $9 \%$ beneden het sector plafond van $60,3 \mathrm{mln}$. $\mathrm{kg}$ stikstof.

\subsection{Ammoniak}

De ammoniakemissie in de landbouw was in 2019 met bijna $106 \mathrm{mln} . \mathrm{kg} \mathrm{5 \%} \mathrm{lager} \mathrm{dan} \mathrm{in} \mathrm{2018.} \mathrm{Daarvoor}$ was die vanaf $2010 \mathrm{~min}$ of meer stabiel op een niveau van 110 à $115 \mathrm{mln}$. $\mathrm{kg} \mathrm{NH}$. De rundveehouderij had in 2019 met $57 \mathrm{mln}$. kg uit dierlijke mest het grootste aandeel, gevolgd door de varkenshouderij met $18 \mathrm{mln} . \mathrm{kg}$ en de pluimveehouderij met $12 \mathrm{mln}$.

Tussen 1990 en 2000 is de ammoniakemissie meer dan gehalveerd tot circa $155 \mathrm{mln}$. $\mathrm{kg} \mathrm{NH}_{3}$ (figuur 6.6). Dit is voornamelijk toe te schrijven aan het wettelijk voorgeschreven emissiearm aanwenden van mest, in de jaren negentig werd het breedwerpig bovengronds uitrijden van mest verboden. Daarnaast is in diezelfde periode het aantal dieren gedaald en was als gevolg van voermaatregelen de stikstofexcretie per dier lager.

$\mathrm{Na} 2000$ is de verdere daling van de ammoniakemissie vooral te danken aan een toename van het aantal emissiearme stallen in de intensieve veehouderij en een afname van de aanwending van dierlijke mest in de Nederlandse land- en tuinbouw, doordat er meer mest wordt geëxporteerd. De daling tussen 2018 en 2019 is toe te schrijven aan minder dieren in de rundveehouderij, als gevolg van de invoering van het fosfaatquotum voor melkvee, en lagere stikstofgehalten in het voer voor rundvee. Naast ammoniakemissie uit de land- en tuinbouw, vindt er jaarlijks ook ammoniakemissie uit overige sectoren plaats van 14 à $15 \mathrm{mln} . \mathrm{kg}$. 


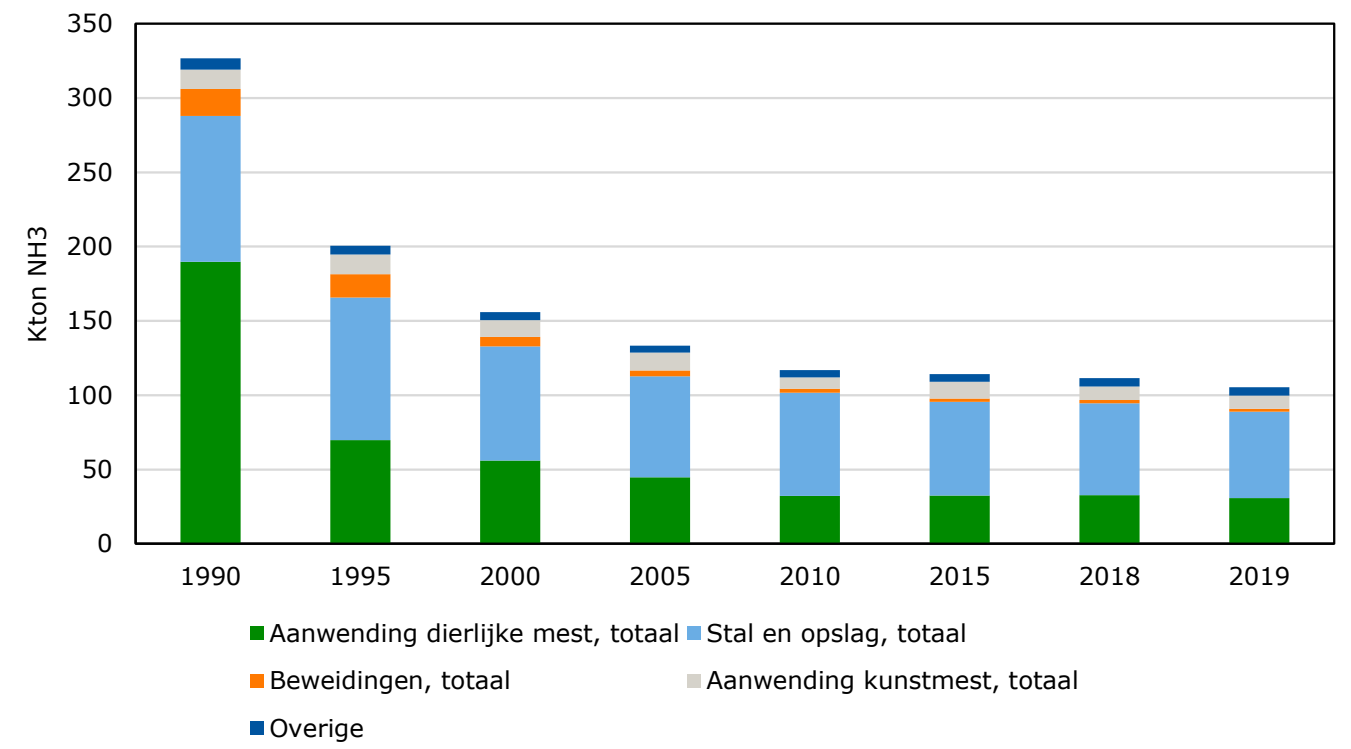

Figuur 6.6 Ammoniakemissie landbouw in Kton $\mathrm{NH}_{3}, 1990-2019$

Bron: Emissieregistratie.nl, bewerking Wageningen Economic Research.

\subsection{Dierenwelzijn en diergezondheid}

\subsubsection{Dierenwelzijn}

In onze cultuur zijn we ons gaan realiseren dat een dier niet alleen maar een gebruikswaarde heeft, maar ook een eigen intrinsieke waarde. In Nederland is de intrinsieke waarde van het dier in 1981 tot uitgangspunt van beleid gemaakt en in 2011 ook opgenomen in de Wet Dieren. De erkenning van de intrinsieke waarde leidt ertoe dat het belang van het dier inzichtelijk wordt gemaakt en wordt afgewogen tegen andere relevante belangen (dierenwelzijnsweb. $\mathrm{nl}$ ).

In de Nederlandse veehouderij staat dierenwelzijn al jaren in de maatschappelijke belangstelling. Het gaat vooral om de vraag in hoeverre dieren hun natuurlijke gedrag kunnen vertonen en om het uitbannen van lichamelijke ingrepen. Momenteel zijn diverse lichamelijke ingrepen nog toegestaan, onder voorwaarden (https://wetten.overheid.nl).

\section{Wet Dieren}

De Wet Dieren dateert uit mei 2011. Recente wijzigingen aangaande Europese diergezondheidswetgeving zijn in 2021 in werking getreden. De wet behelst een integraal kader voor regels over gehouden dieren. Het gaat dan om regels voor onder andere het welzijn en de integriteit van het dier, gezondheid, gebruik van diergeneesmiddelen, en eerlijke handel.

Een in mei 2021 door de Tweede en Eerste Kamer aangenomen amendement op de Wet Dieren beoogt te bereiken dat dieren zich vanaf 1 januari 2023 niet hoeven aan te passen aan hun huisvesting en dat de huisvesting ruimte moet bieden voor hun natuurlijke gedrag. Kernpunt van het amendement is dat een bepaald type huisvesting of houderijsysteem niet mag gelden als een 'redelijk doel' om het dier te benadelen, bijvoorbeeld door fysieke ingrepen te doen en het welzijn te ondermijnen. Als voorbeelden worden in de toelichting bij het amendement genoemd: het ontbreken van zwemwater voor eenden, geen mogelijkheid tot graven voor konijnen, diverse fysieke ingrepen zoals het couperen van biggenstaartjes, het onthoornen van kalfjes en geiten en het verwijderen van de achterste tenen bij hanen die als ouderdier worden gehouden (www.tweedekamer.nl). Het amendement, dat in de toelichting vraagt om inwerkingtreding per 2023, wordt nog door het ministerie van LNV bestudeerd. Onzeker is hoe termen als 'benadeling', 'dierenwelzijn', 'huisvesting' en 'houderijsysteem' door een rechter geïnterpreteerd zullen 
worden, en of aangetoond kan worden wat het doel van een benadeling was, zodat vastgesteld kan worden of er een 'redelijk doel' was.

De wet is niet heel duidelijk over de definitie van natuurlijk gedrag, een uitwerking daarvan zal nog moeten komen. Verder kondigde minister Carola Schouten aan, in een brief aan de Tweede Kamer op 15 juli 2021 , dat ze een wetswijziging zal voorbereiden om te borgen dat gezelschapsdieren worden uitgesloten van het toepassingsbereik van de wetswijziging (www.tweedekamer.nl). De voorgestelde wetswijziging is heel open geformuleerd, en het is de vraag wat die concreet zal gaan betekenen. De gevolgen voor de veehouderij kunnen ingrijpend zijn en veehouders zullen voldoende tijd moeten krijgen om de verbeteringen te kunnen realiseren.

\section{Stalbranden}

In 2020-2021 heeft de Onderzoeksraad voor Veiligheid (OvV) onderzoek gedaan naar stalbranden in de veehouderij (onderzoeksraad.nl). De afgelopen jaren zijn honderdduizenden dieren bij stalbranden omgekomen. In de periode tussen 2012 en 2020 waren er jaarlijks gemiddeld 37 stalbranden, waarvan 17 met dierlijke slachtoffers. Daarbij overleden gemiddeld 143.000 dieren per jaar, in totaal bijna 1,3 mln. De gevolgen van een stalbrand zijn meestal desastreus voor dieren in die stal en zeer ingrijpend voor veehouders. Stalbranden leiden ook vaak tot emotionele reacties in de samenleving en zijn olie op het vuur van de maatschappelijke discussie over de (on)wenselijkheid van grootschalige veehouderijbedrijven.

Het OvV-onderzoek laat zien dat de aanpak van stalbranden niet tot de gewenste resultaten heeft geleid. Het aantal stalbranden is tussen 2012 en 2020 niet afgenomen en het aantal dieren dat jaarlijks bij een stalbrand om het leven komt is zelfs toegenomen. Van de in de loop der jaren vanuit de sector, verzekeraars en dierenbescherming aanbevolen maatregelen om het dierenleed door stalbranden te beperken zijn er vrijwel geen uitgevoerd. Het draaide volgens de OvV vooral om vrijwillige maatregelen die om economische overwegingen niet zijn uitgevoerd.

Naast de initiatieven in de branche heeft de overheid in 2014 enkele brandveiligheidseisen wettelijk vastgelegd in het Bouwbesluit. Voor het brandveiliger maken van bestaande stallen is er echter nauwelijks wet- en regelgeving. De OvV concludeert dat het voorkomen van stalbranden bij boeren en overheid blijkbaar geen prioriteit heeft. WUR-hoogleraar Bart Gremmen erkent het grote probleem, maar vindt het onrealistisch van veehouders te verwachten dat ze op eigen kosten hun oude stal brandveilig maken. De meeste boeren willen wel investeren in brandveiligheid, maar het kost veel geld en de marges zijn gering. Gremmen stelt dan ook dat de landelijke overheid of de EU het zal moeten subsidiëren. Ook verzekeraars kunnen bijdragen aan het stimuleren van preventieve maatregelen (nos.nl).

In oktober 2021 heeft de minister van Landbouw maatregelen aangekondigd om het aantal stalbranden terug te brengen. Het doel is een halvering van het aantal dodelijke stalbranden en dodelijke dierlijke slachtoffers per sector in 2026, ten opzichte van 2020 (rijksoverheid.nl).

\section{Zorg voor jonge dieren}

Sterfte bij jonge dieren is een onderwerp dat al lang op de agenda staat en steeds terugkomt in maatschappelijke discussies (Raad voor Dierenaangelegenheden, 2021). Het ongemak hierover in de samenleving, komt voort uit het feit dat het om jonge dieren gaat en het meestal een voortijdige en voor het gevoel onnodige dood betreft. Voor veel mensen is dit een indicatie van mogelijke achterliggende problemen in de vorm van tekortschietende verzorging, of een economisch systeem dat goede zorg in de weg staat. Dat sterfte van jonge dieren onwenselijk is wordt breed gedragen. Het is nooit helemaal te voorkomen, maar het is van belang om te streven naar de beste zorg en een zo laag mogelijk sterftepercentage. In diverse veehouderijsectoren is de sterfte bij jonge dieren een belangrijk aandachtspunt, en het speelt ook volop bij gezelschapsdieren, zoals honden, katten en konijnen. Veehouders hechten belang aan het verminderen van sterfte bij jonge dieren in het belang van het dierenwelzijn, de economie en de acceptatie van de veehouderij in de maatschappij. Al in 2009 beloofde de varkenshouderij om de sterfte van biggen terug te dringen, maar de sector heeft het destijds gestelde doel nog niet behaald. Wel lijkt in 2019 de trend van een verder stijgende biggensterfte te zijn gekeerd. 
In de varkenshouderij is de biggensterfte al jaren een punt van discussie. De productiviteit in de zeugenhouderij is sterk toegenomen van 23 grootgebrachte biggen per zeug per jaar in 2005 naar circa 30 biggen in 2020 (BINternet, www.agrimatie.nl). Ouweltjes et al. (2020) stellen op basis van de (enigszins gedateerde) literatuur dat de gemiddelde perinatale biggensterfte in Nederland $18,5 \%$ is op gangbare bedrijven (inclusief gemiddeld $6,2 \%$ doodgeboren biggen) en $29,4 \%$ op biologische bedrijven (inclusief gemiddeld 6,6\% doodgeboren biggen). Ze beschouwen zeer goed management als een belangrijke voorwaarde om de negatieve gevolgen van verdergaande selectie op worpgrootte te compenseren. Als factoren worden genoemd een meer gebalanceerde fokkerij, verbeterde perinatale zorg, adequate voeding van drachtige en lacterende zeugen en een passend klimaat voor zeugen en biggen. Een varkenshouder is gebaat bij een type varken dat goed past in zijn bedrijfsvoering. Roskam et al. (2020) stellen voor om bigoverleving inzichtelijk te maken op een wijze die vergelijkbaar is met de systematiek van antibioticareductie: door te benchmarken. Elk bedrijf krijgt een kleurcode (groen, oranje, rood) op basis van de bigoverleving ten opzichte van de streefwaarde. De streefwaarde is afgeleid van het groepsgemiddelde en van de streefwaarde van het fokproduct of sector. Diverse sectoren zijn inmiddels bezig om de zorg voor jonge dieren beter in beeld te krijgen.

Ook de Raad voor Dierenaangelegenheden (2021) adviseert om te gaan benchmarken. De RDA stelt dat de veehouder verantwoordelijk is voor goede dagelijkse zorg voor zijn of haar dieren, maar ook tegen systeemfactoren kan aanlopen, zoals bijvoorbeeld foklijnen die tot gezondheidsproblemen leiden, of afnemers die weinig voor de dieren en producten daarvan betalen. Voor deze factoren zijn anderen mede verantwoordelijk, bijvoorbeeld de fokkerijorganisaties of de supermarkten. Daarom moeten ook die partijen betrokken worden bij het werken aan oplossingen.

Verder lezen

Op agrimatie is meer te lezen over de specifieke welzijnsproblematiek bij melkvee, varkens en pluimvee. ${ }^{67}$

\subsubsection{Diergezondheid}

One Health-benadering om gezondheid van dieren te verbeteren

In Nederland leven mensen en dieren dicht bij elkaar en is hun gezondheid nauw met elkaar verbonden. Eén van de doelen van de One Health-benadering is om de gezondheid van dieren te verbeteren, zodat mensen en dieren zonder problemen samen in een gebied kunnen leven. Daarbij gaat het onder andere over voedselveiligheid, antibioticaresistentie en zoönosen, infectieziekten die overdraagbaar zijn van dieren op mensen.

Ook een gezonde leefomgeving is van groot belang. Intensieve veehouderij in een gebied waar veel mensen wonen kan leiden tot gezondheidsproblemen door fijnstof. De gezondheid van de boeren en hun medewerkers is uiteraard ook van belang. Dat is voor de varkenssector een reden om aan de slag te gaan met fijnstof en endotoxinen. Endotoxinen zijn resten van dode bacteriën en micro-organismen, die voorkomen in fijnstof en bij inademing gezondheidsschade kunnen veroorzaken. De Producenten Organisatie Varkenshouderij (POV) heeft in 2019 een onderzoek uitgevoerd op negenenveertig varkensbedrijven, waaruit blijkt dat de blootstelling aan stof en endotoxinen in de afgelopen decennia niet is afgenomen. POVbestuurslid José Houben noemt de gemeten blootstelling 'hoog' en wijst op de risico's voor varkenshouders en hun medewerkers (www.nieuweoogst.nl).

\section{Antibioticagebruik sterk afgenomen}

Het antibioticagebruik in de Nederlandse veehouderij wordt intensief gevolgd. Hiervoor zijn er twee bronnen van informatie: verkoop van antibiotica in kilogrammen actieve stof voor de hele veehouderij en de monitoring van het antibioticagebruik op de veehouderijbedrijven. Antibiotica mogen alleen worden gebruikt bij zieke dieren (of koppels met zieke dieren), op voorschrift van een dierenarts. Tot 2006 gebruikten veel veehouderijsectoren nog 'groeibevorderaars', kleine hoeveelheden antibiotica, die standaard aan het veevoer werden toegevoegd. Deze vorm van preventief gebruik is sindsdien in de EU niet meer toegestaan. Inmiddels is ook ander preventief gebruik verboden.

\footnotetext{
${ }^{67}$ https://www.agrimatie.nl/PublicatiePage.aspx?subpubID $=2525 \&$ sectorID $=3534$ \&themaID $=2270$ \&indicatorID $\% 20=\% 203517$
} 
De aan dierenartsen verkochte hoeveelheid werkzame stof is in 2020 met 2,1\% licht gestegen naar 153,5 ton (figuur 6.7). De daling in de verkoop ten opzichte van het door de overheid aangewezen referentiejaar 2009 is nu 69\%: van ongeveer 495 naar 153,5 ton. Het Nederlandse beleid heeft met succes de verkoop van antibiotica voor dieren met bijna 70\% gereduceerd ten opzichte van 2009. De omvang van de veestapel (totale diergewicht) is vanaf 2017 vrij stabiel gebleven.

Het totale gebruik in de door de Autoriteit Diergeneesmiddelen (afkorting: SDa) gemonitorde veehouderijsectoren, in kilogrammen voorgeschreven werkzame stof, is in 2020 licht gedaald met 2,9\% ten opzichte van 2019 (SDa, 2021). Op basis van de monitoring van het antibioticagebruik op de Nederlandse bedrijven, is bekend hoeveel antibiotica in welke sectoren wordt gebruikt. De meeste veehouderijsectoren leveren gegevens aan de SDa van het verbruik van de gehele sector gebaseerd op het gebruik op individuele bedrijven. Hierdoor is na te gaan welk deel van de verkochte antibiotica niet direct te herleiden valt naar de door de SDa gemonitorde sectoren: 7\%. Nadat het verschil tussen de verkoop en het gebruik vorig jaar sterk was afgenomen, is het nu weer toegenomen. Het is onduidelijk wat de fluctuatie in het verschil tussen verkoopcijfers en gebruiksgegevens ieder jaar veroorzaakt. Het kan gaan om variatie in voorraadvorming tussen jaren, maar misschien zijn er ook andere verklaringen. De SDa wil hier in 2021 meer inzicht in krijgen. De aandacht zal vooral worden gericht op het vaststellen van de volledigheid en juistheid van de verkoopcijfers.

Om een adequate behandeling van zieke dieren mogelijk te maken, maar daarbij het risico op resistente bacteriën zo klein mogelijk te maken, zijn er afspraken gemaakt welke groepen antibiotica als eerste, tweede en derde keus gebruikt kunnen worden. Eerstekeuzemiddelen hebben het minste effect op de resistentieontwikkeling. In de meeste sectoren is er een redelijk stabiel patroon in het gebruik van eerste-, tweede- en derdekeuzemiddelen. Bij varkens (waarbij het gebruik bij zeugen, inclusief zuigende biggen, en vleesvarkens apart wordt gerapporteerd), runderen (waarbij de melkvee, kalveren en overige runderen apart rapporteren) en vleeskonijnen bestaat $70-85 \%$ van het gebruik uit eerstekeuzeantibiotica, ongeveer $15-25 \%$ uit tweedekeuzeantibiotica en $0 \%$ tot circa $5 \%$ uit derdekeuzeantibiotica (met name polymyxines). Bij vleeskonijnen is er geen gebruik meer van derdekeuzeantibiotica.

Het expertpanel van de SDa waarschuwt voor te veel gebruik van het derdekeuzeantibioticum colistine in de veehouderij (62\% meer dan in 2017), vooral bij varkens en leghennen. Colistine is van groot belang voor de humane gezondheidszorg en daarom moet het veterinair gebruik juist tot een minimum worden beperkt.

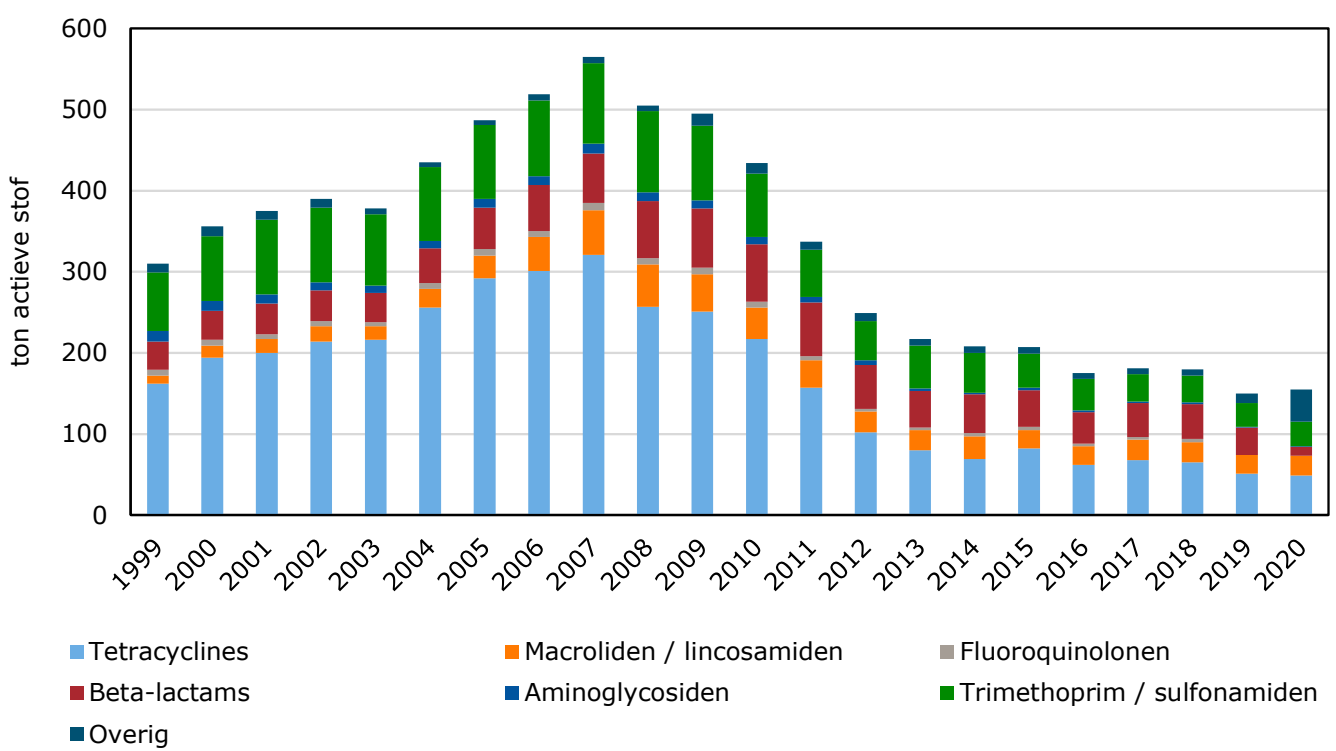

Figuur 6.7 Verkoop van veterinaire antibiotica in Nederland uitgedrukt in $\mathrm{kg}$ actieve stoffen (x 1.000), 1999-2020

Bron: SDa (2021). 
Bij pluimvee is bij zowel vleeskuikens als kalkoenen het aandeel derdekeuzeantibiotica fors gereduceerd, tot $0,9 \%$ bij vleeskuikens en 3,4\% bij kalkoenen. Het aandeel tweedekeuzeantibiotica is met $71,6 \%$ bij vleeskuikens en $35,5 \%$ bij kalkoenen fors hoger in vergelijking met andere sectoren. Het gebruik van de derdekeuzeantibiotica als fluorochinolonen en derde- en vierdegeneratiecefalosporines blijft in de meeste sectoren laag. Het gebruik van fluorochinolonen is in de kalkoensector, de enige sector met een relatief hoog gebruik van dit middel, de afgelopen vijf jaar gedaald van 1,6 tot 0,5 dagdoseringen.

In 2021 zijn voor het tweede jaar nieuwe benchmarkwaarden/actiewaarden voor gebruik op de verschillende veehouderijbedrijven van kracht. In deze systematiek worden twee categorieën onderscheiden:

benchmarkwaarden die aanvaardbaar gebruik reflecteren en die op korte termijn niet zullen veranderen én voorlopige benchmarkwaarden die in de tijd nog regelmatig aangepast zullen worden. Sectoren met benchmarkwaarden voor aanvaardbaar gebruik laten gebruikspatronen zien die gekenmerkt worden door (zeer) laag gebruik, geringe spreiding in gebruik tussen bedrijven en door de tijd. Deze gebruikspatronen gelden voor de sectoren vleeskuikens (actiewaarde: 8 dagdoseringen per dierjaar), zeugen en zuigende biggen ( 5 dagdoseringen), vleesvarkens ( 5 dagdoseringen) en rosé afmestbedrijven (4 dagdoseringen). De overige sectoren werken met voorlopige benchmarkwaarden, die naar verwachting eind 2022 geëvalueerd zullen worden: speenbiggen (20 dagdoseringen), blankvleesbedrijven (23 dagdoseringen), rosé starters (67 dagdoseringen), rosé combinatiebedrijven (start en afmest, 12 dagdoseringen).

Structureel hoog gebruik, dat wil zeggen twee achtereenvolgende jaren een gebruik boven de actiewaarde, komt nog heel regelmatig voor bij onder andere reguliere vleeskuikens, rosévlees afmestkalveren en alle diercategorieën in de varkenssector. Binnen deze sectoren moet de aandacht vooral gericht zijn op de bedrijven die structureel veel antibiotica gebruiken. In andere sectoren (kalkoen- en konijnensector, kalversector met uitzondering van rosévlees afmest,) is juist een sectorbrede aanpak nodig om tot een verdere reductie te komen.

Verder lezen

Op agrimatie.nl thema dierenwelzijn - antibioticagebruik ${ }^{68}$ is voor de sectoren melkvee, varkenshouderij, vleeskalverhouderij en vleeskuikenhouderij meer gedetailleerde informatie beschikbaar over het antibioticagebruik.

\subsection{Agrarisch natuurbeheer en biodiversiteit}

\subsubsection{Inleiding}

De trends in agrarische biodiversiteit zijn in Europa dalend en al lange tijd zorgwekkend. Een belangrijke factor die hieraan bijdraagt is de verregaande intensivering van de landbouw (Runhaar et al., 2018). Die intensivering heeft een aantal oorzaken van achteruitgang van de biodiversiteit in de hand gewerkt, te weten vermesting (te hoge stikstofdepositie), verdroging (bijvoorbeeld waterpeilverlaging in veenweidegebieden), verdwijning en versnippering van semi-natuurlijk areaal (het verdwijnen van perceelsgrenzen, landschapselementen, overhoekjes en dergelijke), monoculturen en vervuiling van de natuurlijke leefomgeving door gewasbeschermingsmiddelen (Berkhout et al., 2019). Daarnaast speelt verstedelijking en de daaruit volgende druk op het landelijk gebied een belangrijke rol.

De mate waarin intensivering invloed heeft op de agrarische biodiversiteit, verschilt per ecosysteemtype en per regio. Uit metingen van een set aan kenmerkende soorten van verschillende ecosystemen in Nederland blijkt conform dit Europese beeld, dat vanaf 1994 de gemiddelde kwaliteit van landnatuur is afgenomen en de laatste jaren niet verder afneemt, maar ook niet duidelijk toeneemt (zie figuur 6.8). Dit betekent dat in de Nederlandse natuurgebieden (exclusief landbouwgebieden) de populaties van karakteristieke diersoorten in die periode gemiddeld genomen na 2005 redelijk stabiel zijn, waarbij de positieve effecten van natuurbeleidsmaatregelen in grote lijnen de negatieve effecten van milieudruk compenseren (PBL, 2021). ${ }^{69}$

\footnotetext{
${ }^{68} \mathrm{https}: / /$ www.agrimatie. $\mathrm{nl} /$ ThemaResultaat. aspx?subpubID $=2232 \&$ themaID $=2270$ \&indicatorID $=2008 \&$ sectorID $=2245$

${ }^{69}$ https://themasites.pbl.nl/balans-leefomgeving/indicatoren/nl003157-ecosysteemkwaliteit-land-en-water
} 
In zoetwaterlichamen is de trend een lichte verbetering van de natuurkwaliteit, waarschijnlijk onder invloed van de Kaderrichtlijn Water (zie CLO, 2021a). ${ }^{70}$

In Nederland is de agrobiodiversiteit in soortenrijkdom in een nog hoger tempo gedaald dan elders in Europa (Runhaar et al., 2018). Dit ondanks het gegeven dat Nederland een lange geschiedenis heeft van agrarisch natuurbeheer, zowel op individueel niveau als in de context van agrarische natuurverenigingen (Renting en van der Ploeg, 2001 en Polman, 2002). Dit is op zichzelf al problematisch, maar daar komt nog bij dat sommige specifieke soorten, zoals boerenlandvogels en weidevogels in het bijzonder, juist sterk afhankelijk zijn van Nederlandse graslanden (Kentie et al., 2016) en dat initiatieven om ze te behouden in het agrarisch gebied belangrijk zijn.

Door veranderingen in de landbouw zijn de populaties van kenmerkende broedvogels in het agrarische gebied (weidevogels, akkervogels, vogels van erf en struweel) in de afgelopen eeuw achteruitgegaan. Op basis van schattingen en waarnemingen is na 1960 de trend zichtbaar dat deze groep broedvogels met meer dan $70 \%$ is afgenomen (zie figuur 6.9). Onder de soorten die achteruit zijn gegaan zitten zowel zeldzame soorten (zoals de grauwe gors en kemphaan) als algemene soorten, zoals de grutto, kievit en scholekster (CLO, 2021b). ${ }^{71}$ Het voorgaande maakt het herstel en de versterking van de agrarische biodiversiteit urgent.

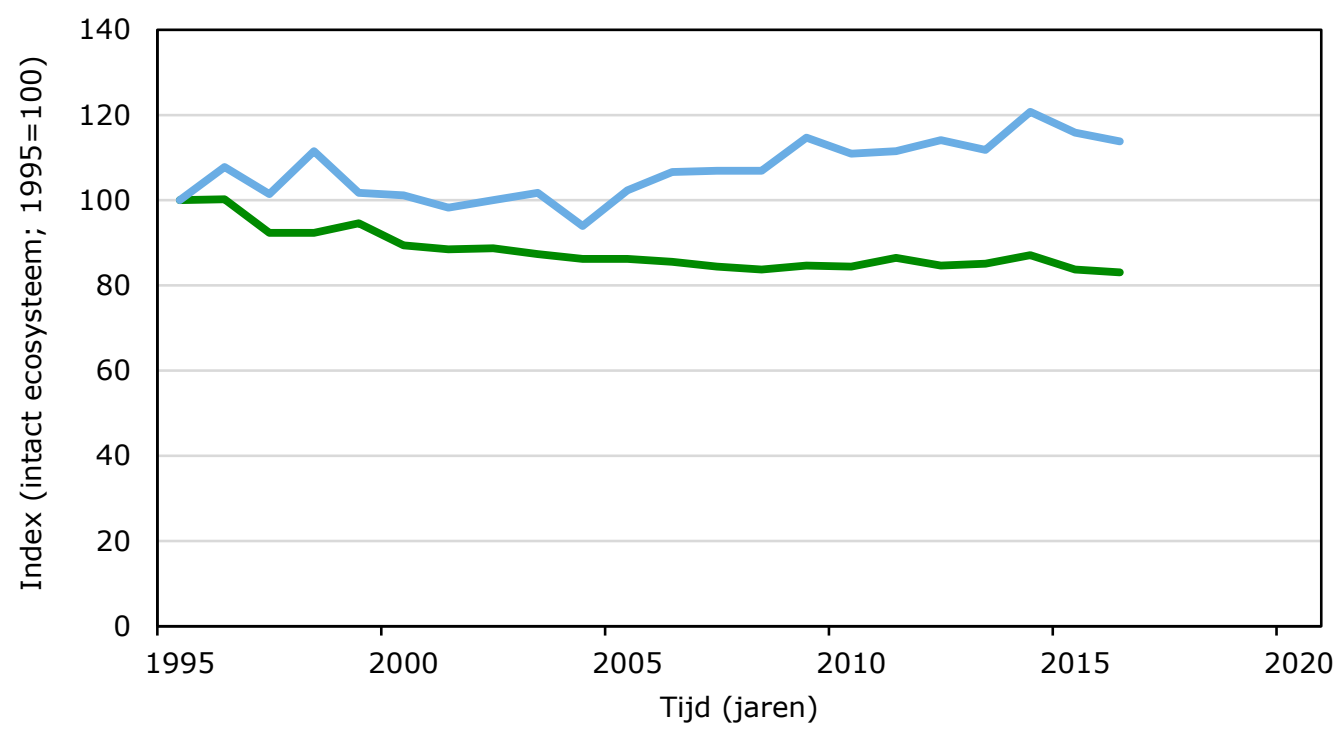

Figuur 6.8 Gemiddelde natuurkwaliteit op land (groen) en in zoetwaterlichamen (blauw) Bron: CLO (2021a).

\footnotetext{
70 https://www.clo.nl/indicatoren/n12052-trend-kwaliteit-natuurtypen

${ }^{71}$ https://www.clo.nl/indicatoren/nl1479-boerenlandvogels
} 


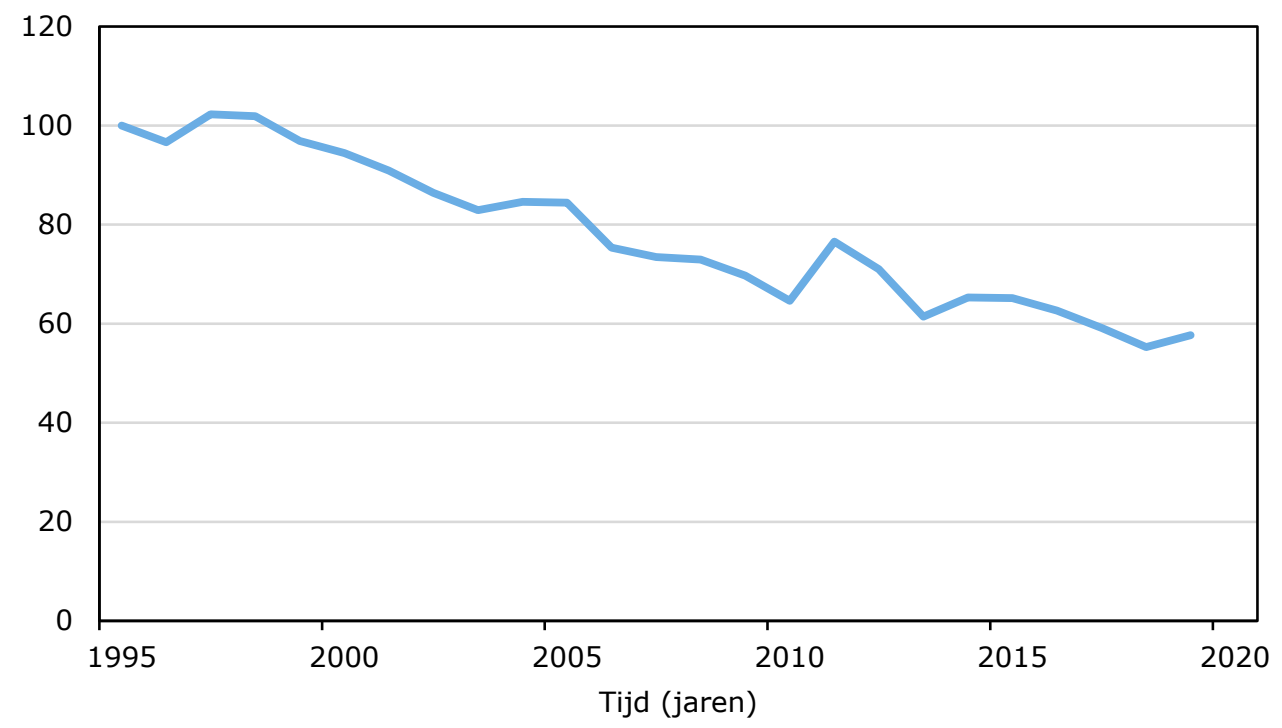

Figuur 6.9 Ontwikkeling van het aantal boerenlandvogels Bron: CLO (2021b).

\subsubsection{Agrarisch natuurbeheer in Nederland}

Bij de vorige hervorming van het GLB (2014-2020) hebben de lidstaten voor het eerst de mogelijkheid gekregen om regelingen voor agrarisch natuurbeheer te organiseren via collectieve overeenkomsten met groepen landbouwers. De Nederlandse regering, die in Brussel voor deze mogelijkheid had gelobbyd, wilde een nieuwe aanpak van beheersovereenkomsten invoeren, die gericht is op het creëren van goede habitatomstandigheden in leefgebieden voor zeldzame soorten, in plaats van de aanpak tot dan, die was gestoeld op verbintenissen die op bedrijfsniveau worden aangegaan (Jongeneel en Polman, 2018). De agrarische collectieven kunnen bij de provincie subsidie aanvragen binnen het stelsel Agrarisch Natuur- en Landschapsbeheer (ANLb) (zie BIJ12, 2021). ${ }^{72}$

In de collectieve aanpak wordt onderscheid gemaakt naar vier typen leefgebied: open grasland, open akkerland, natte dooradering (zoals sloten en poelen) en droge dooradering (houtwallen). Daarnaast is er de categorie water, waarbij het gaat om verbeteren van de waterkwaliteit, vernatting, waterberging en water vasthouden (Michels, 2020). Andere belangrijke doelstellingen van de hervorming waren het vergroten van de doeltreffendheid en de efficiëntie van de uitvoering. Voor het toezicht op en de evaluatie van het beleid wilde men zich meer concentreren op doelstellingen dan op inspanningen of aangegane verbintenissen. Bovendien is er meer flexibiliteit in de maatregelen en plekken waar maatregelen kunnen worden toegepast, wat naar verwachting het doelbereik zal verhogen (Terwan et al., 2016; Mulders, 2018).

Bij de ontwikkeling van het ANLb heeft de Nederlandse overheid besloten dat zij voor agrarisch natuurbeheer alleen nog maar collectieven zal contracteren, in plaats van individuele boeren. Er werden geen beperkingen gesteld aan de omvang van collectieven en deelname is voor boeren vrijwillig gebleven. De collectieven zijn de eindbegunstigde van de subsidies. De collectieven zijn daarmee verantwoordelijk voor een juiste uitvoering van het agrarisch natuurbeheer in hun gebied.

\section{Ontwikkeling collectieve agrarisch natuurbeheer}

In 2020 waren er 40 agrarische collectieven. De collectieven beheerden een areaal van ongeveer 92 duizend hectare in 2019 (tabel 6.2). Dit is exclusief de circa 4.000 ha agrarisch natuurbeheer die nog onder het oude stelsel valt (LNV, IPO en BIJ12, 2020). Het grootste deel van het areaal (circa 81\%) wordt beheerd voor weidevogels.

\footnotetext{
${ }^{72}$ https://www.bij12.nl/onderwerpen/natuur-en-landschap/subsidiestelsel-natuur-en-landschap/agrarisch-natuurbeheer-anlb
} 
Het aantal collectieven verschilt per provincie. Zo is er in Flevoland, Limburg, Zeeland en Drenthe één collectief voor de gehele provincie, terwijl Zuid-Holland er bijvoorbeeld al acht telt. De door de collectieven beheerde oppervlakten variëren van 16.000 ha tot ongeveer 160.000 ha.

Het aantal leden bedroeg in 2016 circa 6.700 en is jaar op jaar gestegen, tot ruim 11 duizend leden in 2020. De uitbetaalde bedragen voor alle leefgebieden en water zijn na de start eveneens gestegen, van $45 \mathrm{mln}$. euro in 2016 tot $71 \mathrm{mln}$. euro in 2019 (tabel 6.2). De groei is ook samengegaan met een verdergaande professionalisering, collectieven moeten bijvoorbeeld gecertificeerd zijn door de stichting Certificering SNL om voor subsidie in aanmerking te komen. Deze professionalisering kan bijdragen aan een effectievere uitvoering en maakt collectieven steeds meer tot een geschikte gebiedspartner voor provincies en waterschappen (Boonstra en Nieuwenhuizen, 2019). Wel zijn er nog flinke verschillen qua professionaliteit tussen de collectieven (Dik et al., 2020).

Tabel 6.2 Aantal betrokken boeren, areaal en betalingen agrarisch natuurbeheer onder stelsel Agrarisch Natuur- en Landschapsbeheer (ANLb)

\begin{tabular}{lrrr}
\hline Jaar & Aantal actief betrokken boeren & Areaal in beheer (ha) & Betaald (mIn. euro) \\
\hline 2016 & 6.656 & 68.227 & 75.224 \\
\hline 2017 & 8.260 & 76.958 \\
\hline 2018 & 9.492 & 92.419 \\
\hline 2019 & 10.486 & 62 \\
\hline 2020 & 11.159 & 71 \\
\hline
\end{tabular}

Bron: aantal boeren via BoerenNatuur; areaal en betalingen: IPO (2017), IPO en LNV (2018), IPO en LNV (2019) en IPO en LNV (2020).

De collectieven stellen een gebiedsaanvraag op die bestaat uit verschillende soorten beheersovereenkomsten (grasland, bouwland en landschapselementen) en een meerjarenplan, waarin een visie op langere termijn inzake het beheer van het gebied en de strategie voor het behoud van de biodiversiteit tot uitdrukking komt. Het Agrarisch Natuur- en Landschapsbeheer (ANLb) richt zich daarbij vooral op 68 doelsoorten van de Vogelen Habitatrichtlijn (VHR), die sterk afhankelijk zijn van de kenmerken van een agrarisch gebied, zoals de intensiteit van grondgebruik en de nabijheid van natuurgebieden. Het merendeel van de doelsoorten bestaat uit vogels en verder gaat het om vissen, amfibieën, insecten en zorgdieren (Boonstra et al., 2021). Het collectief contracteert vervolgens individuele agrariërs of grondgebruikers voor verschillende activiteiten. Hierbij zorgt het collectief ervoor dat de overeenkomst die het met de provincies en waterschappen heeft afgesloten, wordt nagekomen. Dit wordt ook wel het 'voordeur-achterdeur'-principe genoemd. Agrarische collectieven maken immers 'aan de voordeur' afspraken met provincies en waterschappen over de te leveren prestaties en 'aan de achterdeur' met boeren en andere agrarische grondgebruikers over het te voeren beheer op perceelniveau (Boonstra et al., 2021).

De hoogte van de jaarlijkse betalingen aan de collectieven is gebaseerd op de extra kosten en de gederfde inkomsten die voortvloeien uit de aangegane gebiedsovereenkomst. Aanvullend zijn er nog betalingen mogelijk om de uitvoerings- en transactiekosten te dekken (tot $20 \%$ van de betaalde premie aan individuele agrariërs).

\section{Meer flexibiliteit in de uitvoering}

De overgang van contracten met individuele boeren naar een collectieve aanpak heeft een grote initiële inspanning in tijd en geld gevergd van zowel de overheid als de particuliere sector. Uiteindelijk zijn de uitvoeringskosten voor de overheid wel gedaald (Boonstra et al., 2021). Waarschijnlijk kregen de boeren juist te maken met hogere transactiekosten vanwege hun bijdrage aan de uitvoering; daarbij zullen flink hogere kosten impact hebben op de kwaliteit van de uitvoering van het beheer. Of het een besparing is geweest in zowel publieke als private uitvoeringskosten, is moeilijk te zeggen. De transactiekosten die verband houden met de uitvoering, blijven een zorg.

De collectieven bieden mogelijkheden om de agrarische biodiversiteit te behouden (Westerink et al., 2017). Ten opzichte van het vorige stelsel is er meer flexibiliteit en ruimte voor maatwerk op gebiedsniveau, waardoor er ook gedurende het seizoen rekening kan worden gehouden met lokale omstandigheden. Er 
wordt door de provincies dan ook meer gestuurd op hoofdlijnen. De administratie, verantwoording en controles van dit maatwerk vinden op zeer gedetailleerd niveau plaats. De administratieve lasten verschillen per type leefgebied (Boonstra et al., 2021). De verwachting is dat het huidige ANLb alleen onvoldoende is om de negatieve trends van veel VHR-doelsoorten te keren en de waterkwaliteitsdoelstellingen van het landelijk gebied te halen. Boonstra et al. (2021) constateren verder dat voor het vergroten van het doelbereik van het ANLb in algemene zin meer inzet nodig is in de vorm van flankerend beleid, zoals inrichtingsmaatregelen, kavelruil en ondersteuning van gebiedsspecifieke kennisontwikkeling.

\subsubsection{Natuurinclusieve landbouw}

Voor wat betreft het combineren van landbouw en natuurbeheer is in Nederland, naast het agrarisch natuurbeheer, meer gaande. Er is een groeiende bereidheid bij boeren waarneembaar om zich in te zetten voor natuur, ecosysteemdiensten en biodiversiteit. De bijdrage van boerenorganisaties aan het 'Deltaplan Biodiversiteitsherstel' is daar een goed voorbeeld van (Berkhout et al., 2019). In dit plan zetten natuurorganisaties, boeren, burgers, wetenschappers, banken, overheden en bedrijven zich samen in voor biodiversiteitsherstel in Nederland. De vele initiatieven rond natuurinclusieve landbouw sluiten hierop aan, Wat betreft natuurinclusieve landbouw zijn er drie dimensies te onderscheiden, die centraal staan in de Nederlandse beleidscontext (Van Doorn et al., 2016; Smits et al., 2020): zorgen voor de natuur op en om het bedrijf, waaronder 'wilde' natuur (de dimensie verrijken); het duurzaam benutten van natuurlijke processen (benutten); en het minimaliseren van de impact op natuur (sparen). Overigens kan natuurinclusieve landbouw ook bijdragen aan andere doelen in de leefomgeving, zoals schoon water, klimaatadaptatie en emissiereductie.

Het is wel bijzonder lastig om een blauwdruk te geven van hoe een natuurinclusief bedrijf eruit zou moeten zien. Iedere locatie is immers uniek qua ecosysteem, biodiversiteit en natuurlijke processen. Daarnaast is het concept natuurinclusieve landbouw zelf nog sterk in ontwikkeling (Smits et al., 2019). Vooralsnog worden er vier verschillende niveaus van natuurinclusiviteit onderscheiden. De mate van natuurinclusiviteit neemt toe naarmate natuurinclusief werken meer geïntegreerd wordt in de bedrijfsvoering en de omgeving (op basis van Erisman et al., 2017 en EZ, 2017):

- Niveau 0: geen natuurinclusiviteit, maar voldoen aan wettelijke verplichtingen.

- Niveau 1: maatregelen op een deel van het land om de biodiversiteit te bevorderen voor specifieke soorten (bijvoorbeeld collectief agrarisch natuur- en landschapsbeheer, nestkastjes, erfbeplanting of biologische plaagbestrijding in kassen).

- Niveau 2: sluiten van kringlopen op het bedrijf, bijvoorbeeld door duurzaam bodembeheer en zorgvuldig gebruik van natuurlijke hulpbronnen, en meer ruimte voor het natuurlijk gedrag van dieren om de functionele biodiversiteit te verbeteren (boven op de maatregelen die bij niveau 1 horen).

- Niveau 3: het bedrijf vormt één adaptief systeem met het omliggende landschap en bedrijven in de buurt, waarbij kringlopen zo volledig mogelijk zijn en de geteelde gewassen en gehouden veerassen passen bij de kenmerken en (on)mogelijkheden van de omgeving (de maatregelen uit de voorgaande niveaus zijn integraal onderdeel van de bedrijfsvoering).

Bouma et al. (2019) hebben deze niveaus vertaald naar de mate waarin boeren natuurinclusieve maatregelen nemen op hun bedrijf. Niveau 1 bevat maatregelen in de marge van de bedrijfsvoering, oftewel langs de randen van het bedrijf (op 10-20\% van het oppervlakte), niveau 2 maatregelen op de helft van het bedrijf en niveau 3 maatregelen op het hele bedrijf. Bij niveau 1 kan een boer zijn bedrijfsvoering nog relatief ongemoeid laten, maar niveau 2 en 3 hebben consequenties voor de bedrijfsvoering. Aan de hand hiervan hebben Bouma et al. (2019) melkveehouders zichzelf laten classificeren qua natuurinclusiviteit. Daaruit komt naar voren dat ongeveer 39\% regulier boert (niveau 0), 43\% op niveau 1 zit, $11 \%$ op niveau 2 en $6 \%$ op niveau 3. Voor akkerbouw zijn deze percentages respectievelijk 45, 39, 10 en 6\%. Dit geeft aan dat natuurinclusieve landbouw nog altijd een niche is, met inmiddels een flink aantal koplopers. Extra financiële prikkels zouden boeren kunnen stimuleren om ook richting natuurinclusieve landbouw te bewegen (Bouma et al., 2019). Het ontbreekt bovendien nog steeds aan specifieke natuurinclusieve kennis (Grin et al., 2015 en Vermunt et al., 2022) en een gedeelde en concrete visie op natuurinclusieve landbouw (Vermunt et al., 2022). Ook de motivatie en overtuiging van boeren en de bereidheid tot experimenteren en risico's te nemen, kunnen gestimuleerd worden door beschikbare kennis en goede ervaringen met natuurinclusieve landbouw breed toegankelijk te maken. Verder is natuurinclusieve landbouw gebaat bij een 
consistent langetermijnbeleid, waardoor boeren zekerheid hebben over hun inkomen op de langere termijn (Bouma et al., 2019).

\subsubsection{Conclusies en vooruitblik}

Om het gewenste behoud van agrarische biodiversiteit te realiseren, is een brede aanpak noodzakelijk (zie ook Vermunt et al., 2022). Met een passend verdienmodel kunnen economie en natuurinclusiviteit, inclusief agrarisch natuurbeheer via collectieven, elkaar versterken. Natuurinclusieve landbouw is op die manier van groot belang voor de toekomst van de landbouw (zie Jongeneel en Polman, 2020). Dit krijgt vorm door activiteiten en verdienmogelijkheden slim te combineren (zie onder meer Polman en Dijkshoorn (2019) en Hoes (2020) voor voorbeelden hiervan). Veel van de bestaande initiatieven bevinden zich nog in een niche, zoals bijvoorbeeld vermarkten via het label On the way to PlanetProof. Bij dit label voldoen gecertificeerde tuinders, telers en verwerkers aan bovenwettelijke eisen voor onder meer schonere lucht, vruchtbare bodem, goede waterkwaliteit, meer natuur op het landbouwbedrijf en circulaire afvalverwerking en recycling. Niet alleen de ondernemer zelf, maar ook andere ketenpartijen, overheden, NGO's en de consument, moeten stappen zetten om kansen te benutten en barrières te slechten (Grin et al., 2015; Smits et al., 2019; Runhaar et al., 2020; Vermunt et al., 2022). De realisatie van deze natuurinclusieve initiatieven is immers een maatschappelijk vraagstuk, zeker op de langere termijn. Aan de omslag van een hoogproductieve landbouw naar een primaire landbouw die natuurinclusiever produceert, hangt een fors prijskaartje (Berkhout et al., 2021). Verdienmodellen voor de landbouw zijn daarom cruciaal (Polman en Jongeneel, 2020). 


\section{Bronnen en literatuur}

Aanjaagteam Bescherming Arbeidsmigranten (2020). Geen tweederangsburgers; Aanbevelingen om misstanden bij arbeidsmigranten in Nederland tegen te gaan

ABN AMRO (2021) https://www.abnamro.nl/nl/media/Updatesierteelt final consumentenonderzoekNL tcm16-66473.pdf

ACM (2014). Analyse ACM van duurzaamheidsafspraken 'De Kip van Morgen'. Kenmerk: ACM/DM/2014/206028

ACM (2021). Agro-Nutri Monitor 2021

AD (Agrarisch Dagblad) (2021). Frankrijk verbiedt plastic verpakkingen om groente en fruit, 11 oktober 2021 https://www.ad.nl/koken-en-eten/frankrijk-verbiedt-plastic-verpakkingen-om-groente-enfruit a9ee008f/

AD (Autoriteit Diergeneesmiddelen) (2021). https://cdn.ipulse.nl/autoriteitdiergeneesmiddelen/userfiles/sda\%20jaarrapporten\%20ab-gebruik/sda-rapport-hetgebruik-van-antibiotica-bij-Ihd-in-2020-def.pdf

Agrimatie.nl, Grondgebruikstitels https://www.agrimatie.nl/ThemaResultaat.aspx?subpubID=2232\&themaID =3588\&indicatorID =7557

Agrio (2020). Website: https://www.vee-en-gewas.nl/site/assets/files/0/02/98/774/infographic-totaal.pdf, geraadpleegd op 12 oktober 2021

Alston, J.M. (2010). The Benefits from Agricultural Research and Development, Innovation, and Productivity Growth. OECD Food, Agriculture and Fisheries Papers, No. 31, OECD Publishing, Paris

Alston, J.M., W.J. Martin en P.G. Pardey (2015). Chapter 15 - Agricultural R\&D Policy and Long-Run Food Security. In A. Balisacan, U. Chakravorty and M.-L. V. Ravago (Red.), Sustainable Economic Development: Resources, Environment, and Institutions (pp.247-260). New York, NY: Academic Press

Avined (2020). Antibioticumgebruik pluimveesector in 2019. En de trends van afgelopen jaren. GD rapportage op basis van databases CRA en KIP. 5 februari 2020

Avined (2020a). Verdeling houderijsystemen leghennen. Nieuwegein. www.avined.nl

Berkhout, P., A. van Doorn, F. Geerling-Eiff, H. van der Meulen, G. Tacken, G. Venema, Th. Vogelzang, (2019a). De landbouw en het landelijk gebied in Nederland in beeld - een houtskoolschets van de SWOT voor het GLB. Rapport 2019-058, Wageningen Economic Research, Wageningen

Berkhout, Petra en Ron Bergevoet (redactie) (2020). De impact van de coronacrisis op het Nederlandse agrocomplex. Rapport 2020-088. Den Haag, Wageningen Economic Research

Berkhout, P., A. Eweg, A. Jellema, H. van der Meulen en G. Venema (2021). Analyse van de landbouw en het landelijk gebied in Nederland: een SWOT-analyse. Rapport 2021-075, Wageningen Economic Research, Wageningen

BIJ12 (2021). Website: https://www.bij12.nl/onderwerpen/natuur-en-landschap/subsidiestelsel-natuur-enlandschap/agrarisch-natuurbeheer-anlb 
Bloemenbureau Holland (2021). https://www.bloemenbureauholland.nl/perskalender/tweede-metingeffecten-covid-19-op-verkoop-van-bloemen-enplanten?utm source $=$ newsletter\&utm medium =email\&utm campaign=CorporateNL20210408\&utm cont ent=artikel $\operatorname{cov} 19$

Bloemenkrant (2021). https://www.bloemenkrant.nl/nieuws/algemeen/55914/online-verkoop-bloemenstijgt-terwijl-omzet-fysieke-winkels-stagneert

Boerderij (2016). Bijna al het vlees is Varken van Morgen. Boerderij

Boonstra, F.G., W. Nieuwenhuizen (2019). Voortgangsrapportage Agrarisch Natuur- en Landschapsbeheer; Bijdrage aan Jaarverslag Plattelandsontwikkelingsprogramma 2018. Rapport 2953, Wageningen Environmental Research, Wageningen

Boonstra, F.G., W. Nieuwenhuizen, T. Visser, T. Mattijssen, F.F. van der Zee, R.A. Smidt en N.B.P. Polman (2021). Stelselvernieuwing in uitvoering; Tussenevaluatie van het agrarisch- natuur en landschapsbeheer. Wageningen, Wageningen Environmental Research, Rapport 3066

Bouma, J., M. Koetse en J. Brandsma (2019). Natuurinclusieve landbouw: wat beweegt boeren? Het effect van financiële prikkels en gedragsfactoren op de investeringsbereidheid van agrariërs. Rapport Planbureau voor de Leefomgeving, 25 februari

Bouma, J., P. Boot, H. Bredenoord, F. Dietz, M. van Eerdt, H. van Grinsven, M. Kishna, W. Ligtvoet, R. van der Wouden en M. Sanders(2020). Balans van de Leefomgeving 2020. Burger in zicht, overheid aan zet. Den Haag: Planbureau voor de Leefomgeving

Bruggen, van (2020). Dierlijke mest en mineralen 2019. Den Haag, Centraal Bureau voor de Statistiek

Bruil, D.W. (2014). Evaluatie pachtregelgeving. Instituut voor Agrarisch Recht, Wageningen

Buurma, J., K.J. Poppe, H.J. Silvis en M.J. Voskuilen (2016), Bodemkwaliteit in Nederland. Themabericht a.s.r. Juni 2016

Canali, M., P. Amani, L. Aramyan, M. Gheoldus, G. Moates, K. Östergren, K. Silvennoinen, K. Waldron en M. Vittuari (2017). 'Food Waste Drivers in Europe, from Identification to Possible Interventions'. In Sustainability, 9, 37

CBS (2013). Internationalisering en productiviteit: het effect van bedrijf en regio. Den Haag/Heerlen/Bonaire: Centraal Bureau voor de Statistiek

CBS (2017a). Website: https://www.cbs.nl/nl-nl/nieuws/2017/05/nederlandse-landbouwproductie-19502015, geraadpleegd op 12 oktober 2021

CBS (2017b). Website: https://www.cbs.nl/nl-nl/nieuws/2017/24/aantal-bierbrouwers-meer-danverviervoudigd-sinds-2007, geraadpleegd op 12 oktober 2021

CBS (2017c). Website: https://www.cbs.nl/nl-nl/nieuws/2017/07/cbs-ontwikkelt-monitor-brede-welvaart, geraadpleegd op 6 oktober 2021

CBS (2019). Nationale rekeningen 2018. Den Haag/Heerlen/Bonaire: Centraal Bureau voor de Statistiek

CBS (2020a). ICT, Kennis en Economie 2020. Den Haag/Heerlen/Bonaire: Centraal Bureau voor de Statistiek

CBS (2020b). Monitor Brede Welvaart \& de Sustainable Development Goals 2020.

Den Haag/Heerlen/Bonaire: Centraal Bureau voor de Statistiek 
CBS (2020c). Nederland in cijfers: Hoe wordt de Nederlandse bodem gebruikt? Den Haag/Heerlen/Bonaire: Centraal Bureau voor de Statistiek

CBS (2021a). Akkerbouwgewassen; productie naar regio. (https://opendata.cbs.nl/\#/CBS/nl/dataset/7100oogs/table?ts=1633520872538)

CBS (2021b). CBS stat line: https://opendata.cbs.nl/\#/CBS/nl/ landbouwtelling 2021 voorlopige cijfers

CBS (2021c). Bedrijven per bedrijfstak. Via website https://opendata.cbs.nl/statline/\#/CBS/nl/dataset/81589NED/table?ts=1629212399557

CBS (2021d). Consumptieve bestedingen; verbruiksfunctie, nationale rekeningen. Via website https://opendata.cbs.nl/\#/CBS/nl/dataset/84094NED/table?ts=1629300420516

CBS (2021e). Nederland grootste bierexporteur in de Europese Unie (cbs.nl)

CBS (2021f). Website: https://www.cbs.nl/nl-nl/nieuws/2021/04/detailhandel-recordgroei-in-2020-krimp-indecember, geraadpleegd op 12 oktober 2021

CBS (2021g). Website: https://www.cbs.nl/nl-nl/nieuws/2021/16/bijna-900-winkels-minder-in-2020, geraadpleegd op 12 oktober 2021

CBS (2021h). Monitor Brede Welvaart \& de SDG's 2021. Den Haag/Heerlen/Bonaire: Centraal Bureau voor de Statistiek.

CBS (2021i). Vijf jaar implementatie SDG's in Nederland (2016-2020). Den Haag/Heerlen/Bonaire: Centraal Bureau voor de Statistiek

CBS (2021j). Bruto toegevoegde waarde basisprijzen - A Landbouw, bosbouw en visserij - Prijsniveau 2015, seizoengecorrigeerd. Via website:

https://opendata.cbs.nl/\#/CBS/nl/dataset/84105NED/table?ts $=1634026587174$

CBS (2021k). Ontwikkeling arbeidsjaren - A Landbouw, bosbouw en visserij. Via website: https://opendata.cbs.nl/\#/CBS/nl/dataset/84164NED/table?ts $=1634026802608$

CBS (2021l). Energiebalans; aanbod en gebruik - A Landbouw, bosbouw en visserij (finaal energieverbruik). Via website: https://opendata.cbs.nl/\#/CBS/nl/dataset/83989NED/table?ts=1634045904656

CBS (2021m). Emissies naar de lucht door de Nederlandse economie -_A Landbouw, bosbouw en visserij. Via website: https://opendata.cbs.nl/\#/CBS/nl/dataset/83300NED/table?dl=5A88F

CBS (2021n). Emissies broeikasgassen (IPCC); klimaatsectoren - landbouw. Via website: https://opendata.cbs.nl/\#/CBS/nl/dataset/84979NED/table?ts $=1634043552228$

CBS (20210). Watergebruik bedrijven - A Landbouw, bosbouw en visserij. Via website: https://opendata.cbs.nl/\#/CBS/nl/dataset/82883NED/table?ts $=1634045262462$

CBS (2021p). Dierlijke mest- totale mestproductie - landbouw. Via website: https://opendata.cbs.nl/\#/CBS/nl/dataset/83983NED/table?ts $=1634045545160$

CBS (2021q). Activiteiten van biologische landbouwbedrijven. Via website: https://opendata.cbs.nl/\#/CBS/nl/dataset/83922NED/table?ts=1634048235629

CLO (Compendium voor de Leefomgeving) (2014). Afzet gewasbeschermingsmiddelen in de land en tuinbouw. Via website www.compendiumvoordeleefomgeving.nl 
CLO (2019). Website: https://www.clo.nl/indicatoren/nl010116-ammoniakemissie-door-de-land--entuinbouw, geraadpleegd op 6 oktober 2021

CLO (2020). Website: https://www.clo.nl/indicatoren/nl0075-voetafdruk-landgebruik, geraadpleegd op 12 oktober 2021

CLO (2021a), Website: https://www.clo.nl/indicatoren/nl2052-trend-kwaliteit-natuurtypen, geraadpleegd op 1 september 2021

CLO (2021b). Website: https://www.clo.nl/indicatoren/nl1479-boerenlandvogels, geraadpleegd op 1 september 2021

Convenant Marktontwikkeling Verduurzaming Dierlijke Producten (Tussensegmenten) via https://www.parlementairemonitor.nl/9353000/1/j9vvij5epmj1ey0/vi5e8nkfqvxf

Cosun (2021). Toewijzingspercentage voor 2022 105\%. Nieuwsbericht d.d. 4 augustus 2021

Crossminds (2021). https://www.crossminds.nl/news/mooiste-de-deal-van-het-jaar-20202021-gaat-naar/

Dagevos, H., D. Verhoog, P. van Horne en R. Hoste (2019). Vleesconsumptie per hoofd van de bevolking in Nederland, 2005-2019. Nota 2019-108

Dierenbescherming (2020). https://beterleven.dierenbescherming.nl/beter-leven/10-jaar-beter-levenkeurmerk

dierenwelzijnsweb.nl https://www.dierenwelzijnsweb.nl/nl/dierenwelzijnsweb/dierenwelzijn/waarden.htm (geraadpleegd op 24 september 2021)

Dik, L., A. van der Linde, A. Olieman en J. Westerink (2020). Zijn de agrarische collectieven voorbereid op de toekomst? Meer inzicht in de (eigen) organisatie. LD13, Bennekom.

Dooren, C. van (2019). Voedselverspilling bij huishoudens in Nederland in 2019: Syntheserapport. Den Haag: Stichting Voedingscentrum Nederland

Doorn, A. van, D. Melman, J. Westerink, N. Polman, T. Vogelzang, H. Korevaar (2016). Food-for-thought: natuurinclusieve landbouw. Wageningen: Wageningen University \& Research.

EC (Europese Commissie) (2014). Commission staff working document impact assessment on measures addressing food waste to complete swd (2014) 207 regarding the review of eu waste management targets. Brussels, 23.9.2014 SWD(2014) 289 final

EC (European Commission) (2021). https://ec.europa.eu/info/sites/default/files/food-farmingfisheries/farming/documents/beef-production en.pdf

EC (2021a). https://ec.europa.eu/info/food-farming-fisheries/farming/facts-andfigures/markets/overviews/market-observatories/meat/eu-historical-series en

Emissieregistratie. http://www.emissieregistratie.nl/erpubliek/content/emission explanation.nl.aspx\#Afwijkingen

Erisman, J.W., N. van Eekeren, A. van Doorn, W. Geertsema en N. Polman (2017). Maatregelen Natuurinclusieve landbouw. Rapport No. 2821. Wageningen Environmental Research.

EVMI (Expertisecentrum voedingsmiddelenindustrie) (2021). Gezondheid, voeding en bioscience worden focus bij DSM | Evmi 
EZ (Ministerie van Economische zaken) (2014). Meerjarenafspraak Energietransitie Glastuinbouw 2014-2020

EZ (2016). Hulp, handel en investeringen. Tweede Kamer, vergaderjaar 2016-2017, 33 625, nr. 227

EZ (2017). Kamerbrief over natuurinclusieve landbouw. Staatssecretaris van Dam, 10-07-2017, DGAN-NB / 17093609.

EZK (Ministerie van Economische Zaken en Klimaat) (2020). Klimaatplan 2021-2030

FiBL en IFOAM (2021). The World of Organic Agriculture 2020. Frick and Bonn

Financieel Dagblad (FD) (2021). Website: https://fd.nl/bedrijfsleven/1415110/hoge-gasprijs-leidt-tot-legekassen, geraadpleegd op 6 oktober 2021

Floranews (2021).

https://floranews.com/nieuws/16392/Dutch Flower Group krijgt toestemming voor overname Panalpi na Airflo.html

Floranews (2021a).

https://floranews.com/nieuws/4307/Afzetgroei van bloemen en planten in supermarkt is gematigd.h $\underline{\mathrm{tml}}$

Foodstep. https://foodstep.com/over-foodstep/jaarcijfers-omzet-foodservice-database/ geraadpleegd 19-08$\underline{21}$

https://www.groentennieuws.nl/article/9286402/marktaandelen-supermarkten-2020-fullservice-wint-vanprijsvechters/ geraadpleegd 19-08-21

FSIN (2021). https://fsin.nl/media/upload/files/Persbericht\%20FSIN\%20Dossier\%20Delivery\%202021.pdf geraadpleegd 19-08-21

Fusions (2014). FUSIONS Definitional Framework for Food Waste. http://www.eufusions.org/index.php/publications/265-establishing-a-common-framework-for-food-waste-definitionand-identifying-its-drivers

Fusions (2016). Estimates of Europen Food Waste Levels. Estimates of European food waste levels final report 210316 (eu-fusions.org)

Galen, M.A., van en L. Ge (2009). Innovatiemonitor 2008; Vernieuwing in de land-en tuinbouw ontcijferd. LEI-rapport 2009-027. LEI Wageningen UR

Galen, M.A. van, en R.W. van der Meer (2020). Innovatie in de land- en tuinbouw 2020. (Wageningen Economic Research rapport; No. 2020-126). Wageningen Economic Research. https://edepot.wur.nl/535583

Galen, Michiel van, Willy Baltussen, Mariel Benus, Koos Gardebroek (Wageningen University), Nera Herceglić, Robert Hoste, Rico Ihle (Wageningen University), Jakob Jager, Bas Janssens, Gerben Jukema, Marcel Kornelis, Marvin Kunz, Katja Logatcheva, Elsje Oosterkamp, Jamal Roskam, Huib Silvis, Rob Stokkers (2021). Agro-Nutri Monitor 2021 - Hoofdrapport; Monitor prijsvorming voedingsmiddelen en analyse belemmeringen voor verduurzaming. Wageningen, Wageningen Economic Research, Rapport 2021-082

Gfactueel (2021). 'Aldi: 50 van 120 AGF-artikelen regionaal', 26 augustus 2021, https://www.gfactueel.nl/Home/Nieuws/2021/8/Aldi-50-van-120-AGF-artikelen-regionaal-785873E/ 
Gocsik, Éva, Suzanne D. Brooshooft, Ingrid C. de Jong, Helmut W. Saatkamp (2016). 'Cost-efficiency of animal welfare in broiler production systems: A pilot study using the Welfare Quality ${ }^{\circledR}$ assessment protocol'. In: Agricultural Systems Volume 146, July 2016, Pag. 55-69.

GFH (Groentenfruithuis) (2021-1). 'Nederlanders blijven meer groenten en fruit kopen', 28-juli 2021 https://groentenfruithuis. $\mathrm{nl} /$ nieuws/marktinformatie/nederlanders-blijven-meer-groenten-en-fruit-kopen

GFH (2021-2). Jaarverslag GroentenFruitHuis 2020, 16 juni 2021 https://groentenfruithuis. $\mathrm{nl} /$ nieuws/algemeen/groentenfruit-huis-publiceert-jaarverslag-2020

GFH (2021-3). 'SIFAV bereikt 85\% duurzaam volume verse groenten en fruit', 17 september 2021, https://groentenfruithuis.nl/nieuws/duurzaamheid/sifav-bereikt-85-duurzaam-volume-verse-groentenen-fruit

Grin, J., N. Polman, M. Dijkshoorn-Dekker, T. Vogelzang (2015). Verdienmodellen voor natuurinclusieve landbouw; Wat ondernemers al doen, en wat de overheid kan doen om opschaling te bevorderen. Wageningen Economic Research, rapport 2015-044, Wageningen

Harmsen, P., S. Lips, H. Bos (Wageningen UR-Food and Biobased Research), B. Smit, S. van Berkum, J. Helming en R. Jongeneel (LEI Wageningen UR) (2014). Suiker als grondstof voor de Nederlandse chemische industrie; gewassen, proces, beleid. Wageningen, FBR-rapport Nummer 1494, www. wageningenur.nl/nl/Publicatie-details.htm?publicationId=publication-way-343536323436; http://edepot.wur.nl/312696

Hein, L. (2021). Natuurlijk kapitaal. Webblog: Wageningen University \& Research

Heyma, Arjan, William Luiten, Gerben Splinter en Linda Puister (2020). De gevolgen van de coronacrisis voor arbeidsmigranten in de land- en tuinbouw. Notitie 2020-82. SEO Economisch Onderzoek en Wageningen Economic Research

Hoes, A.-C., M. Slegers, C. Savelkouls et al. (2020). Toekomstige voedselproductie: een portret van pionierende boeren die bijdragen aan kringlooplandbouw in Nederland. Wageningen Economic Research, Rapport 2020-019.

Horne, P. van. (2017). Competitiveness of the EU poultry meat sector, base year 2017. International comparison of production costs. Wageningen Economic Research, report 2018-116. Wageningen. December 2018

Horne, Peter van (2020). Pluimveevleessector in Nederland, Feiten en cijfers rondom pluimveevlees. Wageningen Economic Research. https://edepot.wur.nl/530584

Hortipoint (2020). https://www.hortipoint.nl/vakbladvoordebloemisterij/dfg-breidt-met-overname-damesplants-verder-uit/

Hoste, R. (2014). Sojaverbruik in de Nederlandse diervoederindustrie 2011-2013; Inventarisatie in opdracht van Stichting Ketentransitie verantwoorde soja. Wageningen, LEI Wageningen UR (University \& Research centre), LEI 14-098.

Hulle, René van en Mark Grotenhuis (2020). Arbeidsmarkt Colland 2020; Arbeidsmarktstructuur sector agrarisch en groen in beeld. Delft, ABF Research

https://wetten.overheid.nl

ILVO: https://ilvo.vlaanderen.be/nl/dossiers/dierenwelzijn 
Ingenbleek, P.T.M., M. Binnekamp, J.C.M. van Trijp en J.J. de Vlieger (2004). Dierenwelzijn in de markt; Een drieluik van consumenten, retailers en belangenorganisaties in Europa. Den Haag, LEI

Invest in Holland (2021a). Website: https://investinholland.com/doing-business-here/industries/agrifood/, geraadpleegd op 12 oktober 2021.

Invest in Holland (2021b). Website: https://investinholland.com/news/the-future-of-farming-why-the-worldshould-admire-the-dutch-approach-to-agriculture/, geraadpleegd op 12 oktober 2021

IPO (2017). Derde Voortgangsrapportage Natuur; Provinciaal natuurbeleid in uitvoering in 2016. Den Haag

IPO en LNV (2018). Vierde Voortgangsrapportage Natuur; Natuur in Nederland; Stand van zaken eind 2017 en ontwikkelingen in 2018. Den Haag

IPO en LNV (2019). Vijfde Voortgangsrapportage Natuur; Natuur in Nederland; Stand van zaken eind 2018 en ontwikkelingen in 2019. Den Haag

IPO en LNV (2020). Zesde Voortgangsrapportage Natuur; Natuur in Nederland; Stand van zaken eind 2019 en ontwikkelingen in 2020. Den Haag

IPPC (2021). Six assessment report. Via https://www.ipcc.ch/assessment-report/ar6/

Jongeneel, R. A., en N.B.P. Polman (2018). Farmer groups as a device to ensure the provision of agrienvironmental services in the Netherlands: a procurement perspective. Paper presented at 92nd Agricultural Economics Society Annual Conference, Warwick, United Kingdom.

https://edepot.wur.nl/464649

Jongh, de, L., R. de Jong, S. Schenau, J. van Berkel, P. Bogaart, C. Driessen, E. Horlings, M. Lof, R. Mosterd, en L. Hein (2021). Natuurlijk Kapitaalrekeningen Nederland 2013-2018. Den Haag/Heerlen/Bonaire: Centraal Bureau voor de Statistiek

Jukema, G.D., P. Ramaekers en P. Berkhout (red.) (2020). De Nederlandse agrarische sector in internationaal verband. Wageningen/Heerlen/Den Haag, Wageningen Economic Research en Centraal Bureau voor de Statistiek, Rapport 2020-001

Jukema, G.D., P. Ramaekers en P. Berkhout (red.) (2021). De Nederlandse agrarische sector in internationaal verband. Editie 2021. Wageningen/Heerlen/Den Haag, Wageningen Economic Research en Centraal Bureau voor de Statistiek, Rapport 2021-001

Keith, F., M. Gautam, A. Goyal en W.F. Maloney (2020). Harvesting Prosperity: Technology and Productivity Growth in Agriculture. Washington D.C.: World Bank

Kentie, R., N.R. Senner, J.C.E.W. Hooijmeijer, R. Márquez-Ferrando, J. Figuerola, J.A. Masero, T. Piersma (2016). 'Estimating the size of the Dutch breeding population of Continental Black-tailed Godwits from 2007-2015 using resighting data from spring staging sites'. In: Ardea, 114, 213- 225. doi:10.5253/arde.v104i3.a7

Kik, M.C., G.D.H. Claassen, M.P.M. Meuwissen, A.B. Smit and H.W. Saatkamp (2021). 'The economic value of sustainable soil management in arable farming systems - A conceptual framework'. In: Eur. Journal of Agronomy, https://authors.elsevier.com/sd/article/S1161-0301(21)00105-2

KNMI (2019). Jaar 2019; Zeer warm, zeer zonnig en landelijk gemiddeld vrij droog. www.knmi.nl/nederlandnu/klimatologie/maand-en-seizoensoverzichten/2019/jaar

LNV (Ministerie van Landbouw, Natuur en Voedselkwaliteit) (2018). Bodembeleid, Tweede Kamerstuk 30015 , nr. 54 
LNV (2019). Realisatieplan Visie LNV: Op weg met nieuw perspectief. Den Haag: Ministerie van Landbouw, Natuur en Voedselkwaliteit

LNV (2020). Jaarlijkse rapportages mestbeleid. Brief aan de Tweede Kamer d.d. 30 juni 2020

LNV (2021). Glastuinbouw en rapport Effecten van actuele ontwikkelingen op prognoses $\mathrm{CO}_{2}$-emissie glastuinbouw. Brief aan de Tweede Kamer der Staten Generaal dd. 15 juli 2021

LNV (2021a). Stand van zaken Subsidieregeling sanering varkenshouderijen. Brief aan de Tweede Kamer d.d. 30 juni 2021

LNV (2021b). Landelijke beëindigingsregeling veehouderijlocaties (Lbv), Maatregel Gerichte Opkoop (MGO) en grondfonds. Brief aan de Tweede Kamer d.d. 31 augustus 2021

LNV (2021c). Voortgang onderzoek Veehouderij en Gezondheid Omwonenden. Brief aan de Tweede Kamer d.d. 9 maart 2021

LNV (2021d). Stand van zaken Subsidieregeling sanering varkenshouderijen. Brief aan de Tweede Kamer d.d. 30 juni 2021

LNV (2021e). Rapportage Nederlands mestbeleid 2020. Den Haag, Ministerie van Landbouw, Natuur en Voedselkwaliteit, Publicatie-nr. 0621-047

LNV (2021f). Publicatie CBS Monitor fosfaat- en stikstofexcretie in dierlijke mest vierde kwartaal 2020. Brief aan de Tweede Kamer d.d. 15 februari 2021

LNV en IenW (2021). Ontwerp 7e Nederlandse actieprogramma betreffende de Nitraatrichtlijn (2022 - 2025). Ministerie van Landbouw, Natuur en Voedselkwaliteit en Ministerie van Infrastructuur en Waterstaat

Logatcheva, K. (2019). Monitor duurzaam voedsel 2018. Wageningen Economic Research. Rapport 2019-090

Logatcheva, K. (2021). Monitor Duurzaam Voedsel: consumentenbestedingen. Wageningen Economic Research Rapport 2021-003 en via website https://www.agrimatie.nl/ThemaResultaat.aspx?subpubID=2232\&themaID =2810\&indicatorID $=2659$

LTO Nederland (2020). Pachtvisie 2020. https://www.Ito.nl/wp-content/uploads/2020/06/Pachtvisie-LTONederland-juni-2020.pdf

Marcato, F. (2021). A journey to improve robustness of veal calves [PhD thesis], Wageningen

Meer, R.W., van der en M.A. van Galen (2017). Innovatie in de land- en tuinbouw 2016. Rapport 2017-116. Wageningen Economic Research

Meer, R.W., van der en M.A. van Galen (2018). Innovatie in de land- en tuinbouw 2017. Rapport 2018-0191. Wageningen Economic Research

Menkveld (2021). Multifunctionele landbouw: zowel last als profijt van coronacrisis. ABN AMRO Sectorprognose Agri, 12 maart 2021

Meulen, van der, Harold, Jakob Jager, Daniel de Jong, Rob Stokkers, Gabe Venema en Marcel Vijn (2019). Kijk op multifunctionele landbouw; omzet 2007-2018. Wageningen University \& Research, Rapport 2019-054

Meulen, Harold van der, Ruud van der Meer en Marcel van Asseldonk (2020). Financiering transitie naar duurzame landbouw; Inzicht in het huidige financieringslandschap en ontwikkelingen. Wageningen, Wageningen Economic Research, Rapport 2020-097 
Meulen, H.A.B. van der, J.H. Wisman, J.H. Jager, G.D. Jukema en R.W. van der Meer (2021). Investeringsniveau duurzame productiesystemen; Duurzaamheidsindicator (DP01) in de Rijksbegroting 2022. Wageningen, Wageningen Economic Research, Nota 2021-143

Michels, R. (2020). Waterbeheer en de landbouw nader beschouwd; Een aanvullende analyse op de houtskool-SWOT. Wageningen, Wageningen Economic Research, Rapport 2020-071

MNCP (2018, 2019). Meerjarig Nationaal Controleplan Nederland. Jaarverslagen 2018 en 2019. Monitor Duurzaam Voedsel, jaren 2010 - 2021

NAGF (2019). 'Ga voor kleur LAB, kleurrijke verleidingen in de supermarkt stimuleert de verkoop van groenten en fruit'. Via https://nagf.nl/assets/Uploads/ccf9da0d63/rapport-nagf-vu-ga-voor-kleur-lab2019.pdf

NAK (2021). Statistiek gekeurde opp. granen, peulvruchten en fijne Ibz. in 2021. (https://www.nak.nl/wpcontent/uploads/2021/08/Overzicht-te-velde-goedgek.-granen-en-peulvruchten-hybride-2021.pdf)

Nevedi (2020). https://www.nevedi.nl/themas/verduurzaming-grondstoffen

Nhnieuws (2021). 'Race tegen het tomatenvirus: hoe West-Friese zaadbedrijven zoeken naar een oplossing', 22 maart 2021, https://www.nhnieuws.nl/nieuws/282559/race-tegen-het-tomatenvirus-hoe-west-friesezaadbedrijven-zoeken-naar-een-oplossing

Nieuweoogst (2021). https://www.nieuweoogst.nl/nieuws/2021/02/12/sierteelt-voorop-in-verkoop-viakorte-keten

Nieuweoogst (2021b). https://www.nieuweoogst.nl/nieuws/2021/08/05/aantal-biologische-varkens-daalt www.nieuweoogst.nl

https://www.nieuweoogst.nl/nieuws/2021/10/04/varkenssector-gaat-aan-de-slag-met-stof-enendotoxinen

www.nos.nl

https://nos.nl/artikel/2385775-het-systemische-probleem-achter-de-dood-van-dieren-bij-stalbranden (geraadpleegd op 24 september 2021)

OESO (2015). Frascati Manual 2015: Guidelines for Collecting and Reporting Data on Research and Experimental Development, The Measurement of Scientific, Technological and Innovation Activities. Parijs: Organisatie voor Economische Samenwerking en Ontwikkeling

OESO (2019). Innovation, Productivity and Sustainability in Food and Agriculture: Main Findings from Country Reviews and Policy Lessons. OECD Food and Agricultural Reviews. Parijs: Organisatie voor Economische Samenwerking en Ontwikkeling

Onder glas (2021). https://www.onderglas.nl/rozenteelt-dreigt-uit-nederland-te-verdwijnen/

OPNV (2020). http://opnv.nl/

Ouweltjes, W., J.C. Verkaik, H. Hopster (2020). Vroege sterfte bij kalveren, biggen en geitenlammeren; Percentages, oorzaken en mogelijkheden tot reductie. Wageningen Livestock Research, rapport 1182. https://edepot.wur.nl/511711

Pardey, P.G., C. Chan-Kang, S. Dehmer, J.M. Beddow, T.M. Hurley, X. Rao en J.M. Alston (2014). Investments in and the Economic Returns to Agricultural and Food R\&D Worldwide. In N.K. Van Alfen (Red.), Encyclopedia of Agriculture and Food Systems (pp. 78-97) 
Peet, G. van der, F. Leenstra, I. Vermeij, N. Bondt, L. Puister en J. van Os (2018). Feiten en cijfers over de Nederlandse veehouderijsectoren 2018. Wageningen Livestock Research Rapport 1134

Peet, G. van der (2020). Monitoring integraal duurzame stallen. Wageningen Livestock Research. Rapport 1183. Wageningen

Pleijte, M., R. During, H.J. Silvis en H. Docters van Leeuwen (2020). Goed verpacht, beter beheerd; Een onderzoek naar het borgen van de kwaliteit van Nederlandse landbouwbodems in pachtafspraken, in opdracht van het Rijksvastgoedbedrijf. Wageningen, Wageningen Environmental Research, Rapport 3027

Pluimveeweb (2014). https://www.pluimveeweb.nl/artikel/173760-10-jarig-jubileum-beter-leven-keurmerken-volwaard/

PBL (Planbureau voor de Leefomgeving) (2018). Uitgangspuntennotitie voor de onderhandelingen aan de sectortafel Landbouw en Landgebruik

PBL (2020). Balans van de Leefomgeving 2020. Burger in zicht, overheid aan zet. PBL-publicatienr: 4165, Den Haag

PBL (2021). Website: https://themasites.pbl.nl/balans-leefomgeving/indicatoren/nl003157ecosysteemkwaliteit-land-en-water, geraadpleegd op 7 oktober 2021

Polman, N.B.P. en M. Dijkshoorn (red.) (2019). Verdienmodellen natuurinclusieve landbouw. Wageningen Economic Research brochure

Polman, N. en R. Jongeneel (2020). Voor een natuurinclusieve landbouw zijn nieuwe verdienmodellen nodig. ESB 105(4791S), 96-101

Polman, N.B.P. (2002). Institutional economics analysis of contractual arrangements; managing wildlife and landscape on Dutch farms. PhD-thesis, Wageningen University

POV (2020). https://www.pov.nl/dossiers-en-thema-s/kks-holland-varken/ en http://www.hollandvarken.nl/

Raad voor Dierenaangelegenheden, 2021. RDA zienswijze Zorg voor het jonge dier - Naar meer aandacht voor het individuele dier en minder sterfte. https://www.rda.nl/binaries/raad-voordierenaangelegenheden/documenten/zienswijzen/2021/01/25/rda-zienswijze-zorg-voor-het-jonge-diervolledig-rapport/RDA+zienswijze+Zorg+voor+het+jonge+dier+\%28volledig+rapport\%29.pdf

Retaildetail (2021). 'Frankrijk bant plastic verpakkingen voor fruit en groenten', 12 oktober 2021 https://www.retaildetail.nl/nl/news/food/frankrijk-bant-plastic-verpakkingen-voor-fruit-en-groenten

Rijksoverheid (2019b). Website: https://www.rijksoverheid.nl/actueel/nieuws/2019/06/17/omslag-naarduurzame-en-sterke-landbouw-definitief-ingezet, geraadpleegd op 12 oktober 2021

RIVM (2019). Website: https://www.rivm.nl/rivm/kennis-en-kunde/expertisevelden/gezonde-en-duurzamelandbouw, geraadpleegd op 12 oktober 2021

RIVM (2020). Website: Stikstof - Actueel | RIVM, geraadpleegd op 22 november 2021

RIVM (2021). https://wateetnederland.nl/resultaten/voedingsmiddelen/consumptie/fruit

RIVM Voedselconsumptiepeiling 2012-2016

https://www.wateetnederland.nl/resultaten/voedingsmiddelen/plaats

Roskam, Jamal, Jan ten Napel, Karel de Greef, Geert van der Peet (2020). Bigoverleving vanuit fokkerijperspectief. https://edepot.wur.nl/537138 
Royal Flora Holland (2021). https://www.royalfloraholland.com/nieuws/royal-floraholland-presenteertvernieuwde-aanpak-digitale-milieuregistratie-en-milieucertificering

Royal Flora Holland (2021a). https://np-royalfloraholland-production.s3-eu-west1.amazonaws.com/umbraco/media/15231675/royal-floraholland-jaarverslag-2020-nl.pdf

RVO (2021). RVO I\&R Dierregistraties. https://www.rvo.nl/onderwerpen/internationaal-ondernemen/handelplanten-dieren-producten/marktinformatie/statistieken

RVO (2021a). Blijvend grasland 2021

https://www.rvo.nl/subsidie-en-financieringswijzer/vergroeningsbetaling-2021/blijvend-grasland-2021

www.rijksoverheid.nl

- https://www.rijksoverheid.nl/binaries/rijksoverheid/documenten/kamerstukken/2021/08/27/kamerbrie f-verzamelbrief-dierenwelzijn/kamerbrief-over-verzamelbrief-dierenwelzijn.pdf (geraadpleegd op 27 september 2021)

- https://www.rijksoverheid.nl/documenten/kamerstukken/2021/10/08/kamerbrief-aanpak-vanstalbranden (geraadpleegd op 11 oktober 2021)

Ruijs, A. en M. Vardon (Red.) (2018). 2nd Policy Forum on Natural Capital Accounting for Better Decision Making: Applications for Sustainable Development. Washington D.C.: World Bank WAVES

Runhaar, H., N. Polman en M. Dijkshoorn-Dekker (2018). 'Self-initiated nature conservation by farmers: an analysis of Dutch farming'. In: International Journal of Agricultural Sustainability, 16(6), 486-497

Runhaar, Hens A.C., Lea Fünfschilling, Agnes van den Pol-Van Dasselaar, Ellen H.M. Moors, Rani Temmink, Marko P. Hekkert (2020). 'Endogenous regime change: lessons from transition pathways in Dutch dairy farming'. In: Environ. Innovat. Soc. Transit. 36 (June), 137-150.

https://doi.org/10.1016/j.eist.2020.06.001.

SDa (Autoriteit Diergeneesmiddelen) (2021). Het gebruik van antibiotica bij landbouwhuisdieren in 2020

Seedvalley (2021). Nieuwe groenten tegen voedse/verspilling! 14 oktober 2021 https://www.seedvalley.nl/nieuwe-groenten-tegen-voedselverspilling/ https://www.rtlnieuws.nl/editienl/artikel/5241597/watermeloen-nederlandse-bodem-fruit-supermarkt

SEO Economische Onderzoek (2020). De gevolgen van de coronacrisis voor arbeidsmigranten in de land- en tuinbouw. Amsterdam: SEO Economisch Onderzoek

Silvis, H.J. en M.J. Voskuilen (2018). Economie van de pacht. Wageningen, Wageningen Economic Research, Nota 2018-082

Silvis, H.J., R.W. van der Meer en M.J. Voskuilen (2021). Pachtnormen 2021; Berekening hoogst toelaatbare pachtprijzen voor los land, agrarische bedrijfsgebouwen en agrarische woningen. Wageningen, Wageningen Economic Research, Rapport 2021-045

Silvis, H. en M. Voskuilen (2021). Verpachtersvermogen in de landbouw groter dan bankleningen. Wageningen, Wageningen Economic Research, notitie 2021-103

SKV (Stichting Kwaliteitsgarantie Vleeskalversector) (2021). Jaarverslag 2020

Smit, A.B., R.A. Jongeneel, H. Prins, J.H. Jager en W.H.G.J. Hennen (2017). Impact of coupled EU support for sugar beet growing: More production, lower prices. Den Haag, Wageningen Economic Research, Report 2017-114, 62 pp. and Executive Summary 2017-114a. https://www.wur.nl/nl/Publicatiedetails.htm?publicationId=publication-way-353331323731 
Smit, B. J. Jager, W. van Everdingen en H. van der Meulen (2019). Gebruik onkruidbestrijdingsmiddelen en glyfosaat in de land- en tuinbouw. Wageningen Economic Research, factsheet 2019-015. http://edepot.wur.nl/472136

Smit, Pepijn en Nico van der Velden (2021). Energiemonitor van de Nederlandse glastuinbouw 2020. Wageningen, Wageningen Economic Research, Rapport 2021-127

Smits, M.J., N. Polman, R. Michels, G. Migchels, R. Schrijver, W. Sukkel, A. Visser, T. Vogelzang en F. Kistenkas (2019). Natuurinclusieve landbouw: van niches naar mainstream (fase 1). Wageningen Economic Research

Smits, M.J., A. Dawson, M. Dijkshoorn-Dekker, R. Ferwerda-van Zonneveld, R. Michels, G. Migchels, N. Polman, R. Schrijver, W. Sukkel, T. Vogelzang en F. Kistenkas (2020). Van A naar Biodiversiteit; Op weg naar een natuurinclusieve landbouw. Wageningen, Wageningen Economic Research, Rapport 2020-043

Stolwijk, Herman (2004). De economische marginalisering van de Nederlandse landbouw, CPB Memorandum, 20 juli 2004

Stundziene, A. en A. Saboniene (2019). Tangible investment and labour productivity: Evidence from European manufacturing. In: Economic Research-Ekonomska Istraživanja. Volume 32, Issue 1, 2019, p. 3519-3537

Tacken, Gemma, Joris Galama, Patricia Jaspers, Victor Immink, Lusine Aramyan (2021). Korteketenproducten in Nederland; Zijn horeca, catering en supermarkten geïnteresseerd in producten uit de regio. Wageningen, Wageningen Economic Research, Rapport 2021-013

Taskforce Korte Keten (2021). Adviesrapport - Nationale Samenwerking Korte Keten (taskforcekorteketen.nl)

Terwan, P., J.G. Deelen, A. Mulders and E. Peeters (2016). The cooperative approach under the new Dutch agri-environment scheme; Background, procedures and legal and institutional implications. LNV, Den Haag

TNO (2019). Website: https://www.tno.nl/nl/over-tno/nieuws/2019/10/factsheet-stikstofemissie/, geraadpleegd op 12 oktober 2021

Tulder, R. van, M. Kaptein, E.M. van Mil en R.A. Schilpzand (2004). De Strategische Stakeholderdialoog Opkomst, succesfactoren en toekomst. Rapport. Erasmus Universiteit Rotterdam/ Schuttelaar \& Partners, Adviesbureau voor Maatschappelijke Communicatie BV. Den Haag/Rotterdam

Velden, N.J.A. van der en P.X. Smit (2020). Raming $\mathrm{CO}_{2}$-emissie glastuinbouw 2020. Rapport 2020-110. Wageningen Economic Research

Westerink, J., R. Jongeneel, N. Polman, K. Prager, J. Franks, P. Dupraz en E. Mettepenningen (2017). 'Collaborative governance arrangements to deliver spatially coordinated agri-environmental management'. In: Land Use Policy, 69, 176-192

www.tweedekamer.nl

- https://www.tweedekamer.nl/kamerstukken/amendementen/detail?did=2021D17045\&id=2021Z07743 (geraadpleegd op 24 september 2021)

- https://www.tweedekamer.nl/kamerstukken/brieven regering/detail?did=2021D29412\&id=2021Z1379 $\underline{9}$ (geraadpleegd op 27 september 2021)

Venema, Gabe, Mariël Benus, Walter van Everdingen, Linda Puister-Jansen, Gerben Splinter, Marcel Vijn en Dominique van Wonderen (2021). Agrarische productie ten behoeve van de korte keten. Een landelijke meting. Wageningen, Wageningen Economic Research, Rapport 2021-067 
Van der Velden, N.J.A. van der en P.X. Smit (2019). Energiemonitor van de Nederlandse glastuinbouw 2018, Rapport 2019-111. Wageningen Economic Research

Velden, Nico, van der en Pepijn Smit (2020a). Energiemonitor van de Nederlandse glastuinbouw 2019. Wageningen, Wageningen Economic Research, Rapport 2020-109

Velden, N.J.A. van der en P.X. Smit (2020b). Raming $\mathrm{CO}_{2}$-emissie glastuinbouw 2020. Wageningen, Wageningen Economic Research, Rapport 2020-110

Vermunt, D.A., N. Wojtynia, M.P. Hekkert, J. Van Dijk, R. Verburg, P.A. Verweij, M. Wassen, H. Runhaar (2022). "Five mechanisms blocking the transition towards 'nature-inclusive' agriculture: A systemic analysis of Dutch dairy farming". In: Agricultural Systems, Volume 195, 103280, ISSN 0308-521X, https://doi.org/10.1016/j.agsy.2021.103280

Verenigde Naties (VN) (2015). Transforming our world: the 2030 Agenda for Sustainable Development. Resolution adopted by the General Assembly on 25 September 2014 (A/Res/70/1). New York: United Nations

Verhoeven, W., P. Gibcus en P. De Jong-'t Hart (2005). Bedrijvendynamiek in Nederland: goed of slecht? EIM

Vink, M., A. van Hinsberg, C. Backes, D. Boezeman, P. van Egmond en D-J van der Hoek (2021). Naar een uitweg uit de stikstofcrisis: overwegingen bij een integrale, effectieve en juridisch houdbare aanpak. Den Haag: Planbureau voor de Leefomgeving

Voedsel Economisch Bericht 2020 https://agrimatie.nl/PublicatiePage. aspx?subpubID $=2525$ \&sectorID $=7335$ \&themaID $=3620$ \&indicatorID\% $\underline{20}=\% 207340$

Wisman, Arjan (2020). NSO-typering agrarische bedrijven 2020; Normen en uitgangspunten bij typering agrarische bedrijven in Nederland. Wageningen, Wageningen Economic Research, Nota 2021-012

WUR (2019). Kringlooplandbouw: een nieuw perspectief voor de Nederlandse landbouw. Wageningen: Wageningen University \& Research

WUR (2020a). Website: https://www.wur.nl/nl/Onderzoek-Resultaten/Onderzoeksinstituten/livestockresearch/show-wlr/Kringlooplandbouw-vraagt-praktische-stappen, geraadpleegd op 12 oktober 2021

WUR (2020b). Website (grondgebruik):

https://www.agrimatie.nl/PublicatiePage.aspx?subpubID $=2525 \&$ themaID $=2286 \&$ sectorID $=3534$, geraadpleegd op 12 oktober 2021

Zwarts, H. (2020). Aloude export-oriëntatie staat verduurzaming van onze landbouw in de weg. In: ESB. Volume 105, Number 4791S, p.59-63 


\section{Bijlage 1 Projectleiding en auteurs}

Projectleiding Wageningen Economic Research

Petra Berkhout, Harold van der Meulen

Projectleiding CBS

Pascal Ramaekers

\section{Hoofdstuk 2. De Nederlandse agrosector}

Wageningen Economic Research

Paragraaf 2.1: David Verhoog, Petra Berkhout

Paragraaf 2.3: Ron Bergevoet, Co Daatselaar, Peter van Horne, Robert Hoste, Bas Janssens, Gerben Jukema, Mark Manshanden, Bert Smit, Yolande de Valk

Paragraaf 2.4: Gerben Jukema

CBS

Paragraaf 2.5: Timon Bohn, Khee Fung Wong, Pascal Ramaekers

\section{Hoofdstuk 3. Voedselconsumptie}

Wageningen Economic Research

Paragraaf 3.1-3.3: Katja Logatcheva

Paragraaf 3.4: Lusine Aramyan

Paragraaf 3.5: Elsje Oosterkamp

\section{Hoofdstuk 4. Land- en tuinbouw}

Wageningen Economic Research

Paragraaf 4.2: Ruud van der Meer, Harold van der Meulen, Martien Voskuilen

Paragraaf 4.3: Linda Puister, Harold van der Meulen

Paragraaf 4.4-4.5: Harold van der Meulen

Paragraaf 4.6: Harold van der Meulen, David Verhoog

Paragraaf 4.7: Huib Silvis, Bert Smit

\section{Hoofdstuk 5. Overige agribusiness}

CBS

Rik van Roekel

Tim Peeters

\section{Hoofdstuk 6. Leefomgeving}

CBS

Paragraaf 6.2: Pascal Ramaekers, Rixt de Jong, Lieneke Hoeksma

Wageningen Economic Research

Paragraaf 6.3: Bert Smit

Paragraaf 6.4-6.7: Harry Luesink

Paragraaf 6.8: Nico Bondt

Paragraaf 6.9: Rolf Michels, Nico Polman 


\section{Bijlage 2 Indicatoren LNV- begroting}

\begin{tabular}{|c|c|c|c|c|c|c|c|c|c|}
\hline \multirow{3}{*}{$\begin{array}{l}\text { Export Nederlandse } \\
\text { agrosector }\end{array}$} & \multirow{3}{*}{$\begin{array}{l}\text { Eenheid } \\
\text { Mln. euro }\end{array}$} & \multicolumn{8}{|l|}{ Waarde } \\
\hline & & \multirow[b]{2}{*}{ Land } & \multirow[b]{2}{*}{2014} & \multirow[b]{2}{*}{2015} & \multirow[b]{2}{*}{2016} & \multirow[b]{2}{*}{2017} & \multirow[b]{2}{*}{2018} & \multirow[b]{2}{*}{2019} & \multirow[b]{2}{*}{2020 (raming) } \\
\hline & & & & & & & & & \\
\hline & & Duitsland & 20.148 & 20.073 & 21.180 & 22.168 & 21.856 & 23.579 & 24.600 \\
\hline & & België & 8.295 & 8.217 & 8.803 & 9.722 & 9.768 & 10.779 & 10.577 \\
\hline & & Verenigd Koninkrijk & 7.850 & 8.034 & 8.109 & 8.304 & 8.252 & 8.658 & 8.415 \\
\hline & & Frankrijk & 6.916 & 6.484 & 6.789 & 7.480 & 7.330 & 7.726 & 7.567 \\
\hline & & Totaal EU & & & & & 69.400 & 63.500 & 64.100 \\
\hline & & China & 1.071 & 1.568 & 2.066 & 2.224 & 2.323 & 3.083 & 3.819 \\
\hline & & Overige landen & 33.914 & 33.542 & 34.516 & 36.508 & 37.188 & 40.797 & 40.593 \\
\hline & & Totaal landen & 78.193 & 77.916 & 81.463 & 86.407 & 86.718 & 94.623 & 95.571 \\
\hline Voldoen aan & $\%$ van het aantal & \multicolumn{8}{|l|}{$2013-88,70 \%$} \\
\hline \multirow[t]{2}{*}{ controlevereisten HACCP } & gecontroleerde bedrijven & \multicolumn{8}{|l|}{$2019-91,10 \%$} \\
\hline & & \multicolumn{8}{|l|}{$2020-89 \%$} \\
\hline Vertrouwen consument & Mate van vertrouwen & \multicolumn{8}{|l|}{$2015-3,2$} \\
\hline \multirow[t]{3}{*}{ in veiligheid voedsel } & consumenten in voedsel & \multicolumn{8}{|l|}{$2018-3,2$} \\
\hline & (schaal 1-5) & \multicolumn{8}{|l|}{$2019-3,2$} \\
\hline & & \multicolumn{8}{|l|}{$2021-3,1$} \\
\hline Afgeleide & \multicolumn{9}{|l|}{ Kiloton } \\
\hline \multirow[t]{2}{*}{$\begin{array}{l}\text { Voedselverspilling in } \\
\text { kiloton (absoluut) }\end{array}$} & & & & 2015 & 2016 & 2017 & 2018 & $\begin{array}{r}\text { Meest } \\
\text { recente jaar }\end{array}$ & th Streefwaarde \\
\hline & & \multicolumn{2}{|c|}{$\begin{array}{l}\text { Afgeleide voedselverspilling in } \\
\text { kiloton (absoluut) }\end{array}$} & 2.162 & 2.124 & 2.162 & 2.109 & 2018 & \begin{tabular}{l|l|}
8 & $1.081(2030)$
\end{tabular} \\
\hline
\end{tabular}

\section{Afgeleide}

voedselverspilling in $\%$

(relatief t.o.v. 2015)
Kiloton

\begin{tabular}{|l|r|r|r|r|r|r|}
\hline & 2015 & 2016 & 2017 & 2018 & $\begin{array}{r}\text { Meest } \\
\text { recente jaar }\end{array}$ & Streefwaarde \\
\hline $\begin{array}{l}\text { Afgeleide voedselverspilling in } \\
\% \text { (relatief) }\end{array}$ & 100 & 98 & 100 & 98 & 2018 & 50 \\
\hline
\end{tabular}

Totale

consumentenbestedingen

aan duurzaam voedsel

(mld. euro)

\section{Marktaandeel van}

bestedingen aan

duurzaam voedsel in de

totale bestedingen aan

voedsel

Bestedingen van

consumenten aan

duurzaam voedsel ten

opzichte van het

voorgaande jaar
Productie van dierlijke mest uitgedrukt in $\mathrm{mln}$.

kg stikstof

$\%$

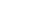

$\%$

\begin{tabular}{|l|r|r|r|r|}
\hline $\begin{array}{l}\text { 3: Bestedingen van consumenten aan duurzaam } \\
\text { voedsel ten opzichte van het voorgaande jaar }\end{array}$ & $19 \%$ & $7 \%$ & $18 \%$ & $7 \%$ \\
\hline
\end{tabular}

mln. kg stikstof

\begin{tabular}{|l|r|r|r|r|r|}
\hline & Plafond & 2017 & 2018 & 2019 & 2020 \\
\hline Landelijk & 504,4 & 512 & 503,5 & 489,7 & 489,4 \\
\hline Melkvee & 281,8 & 303,5 & 289,9 & 279,7 & 286,5 \\
\hline Varkens & 99,1 & 97,4 & 96,8 & 93,7 & 91,8 \\
\hline Pluimvee & 60,3 & 58,9 & 56,7 & 56 & 54,7 \\
\hline
\end{tabular}


Eenheid

Productie van dierlijke mest uitgedrukt in $\mathrm{mln}$.

$\mathrm{kg}$ fosfaat $\mathrm{mln}$. kg fosfaat

Waard

\begin{tabular}{|l|r|r|r|r|r|}
\hline Plafond & 2017 & \multicolumn{2}{|c|}{2018} & 2019 & 2020 \\
\hline Landelijk & 172,9 & 169 & 162 & 155,5 & 150,7 \\
\hline Melkvee & 84,9 & 86,6 & 78,7 & 75,5 & 73,6 \\
\hline Varkens & 39,7 & 37,5 & 37,7 & 36,8 & 36,7 \\
\hline Pluimvee & 27,4 & 27,5 & 25,9 & 25,1 & 24,1 \\
\hline
\end{tabular}

Gemiddelde gemiddeld $<$ of $=50 \mathrm{mg}$

nitraatconcentratie per Nitraat/l uitspoeling uit

liter in uitspoelend water wortelzone onder

onder landbouwbedrijven landbouwgrond

\begin{tabular}{|l|r|r|}
\hline $\begin{array}{l}\text { Bodem } \\
\text { soort }\end{array}$ & $2015-$ & $2016-$ \\
2019 & 2019 \\
\hline Löss & 68 & 63 \\
\hline Zand & 55 & 50 \\
\hline Klei & 23 & 30 \\
\hline Veen & 8 & 7 \\
\hline
\end{tabular}

\begin{tabular}{|c|c|c|}
\hline & & \\
\hline \multicolumn{2}{|l|}{ Energie-efficiency index } & $2018-78,3 \%$ \\
\hline \multicolumn{2}{|l|}{ voedings- en } & $2019-77,2 \%$ \\
\hline \multirow{2}{*}{\multicolumn{2}{|c|}{$\begin{array}{l}\text { genotmiddelenindustrie } \\
\text { (VGI) }\end{array}$}} & $2020-76,1 \%$ \\
\hline & & \\
\hline \multirow{4}{*}{$\begin{array}{l}\text { Totale } \mathrm{CO}_{2} \text {-emissie } \\
\text { glastuinbouw }\end{array}$} & \multirow[t]{4}{*}{ Mton } & 2013 - 7,5 Mtor \\
\hline & & 2017 - 5,7 Mtor \\
\hline & & 2018 - 5,7 Mtor \\
\hline & & $2019-5,9$ Mtor \\
\hline
\end{tabular}

\section{Afname}

antibioticagebruik in

dierhouderij (\%)

\begin{tabular}{|r|r|r|}
\hline 2019 & 2020 & 2021 \\
\hline $69,6 \%$ & $69 \%$ & Nog niet bekend \\
\hline
\end{tabular}

Oppervlakte ANLB

$\mathrm{Ha}$

beheerd landbouwareaal

\begin{tabular}{|l|r|r|r|}
\hline Jaar & $\begin{array}{r}\text { Aantal actief betrokken } \\
\text { boeren }\end{array}$ & Areaal in beheer (ha) & Betaald (m/n. euro) \\
\hline 2016 & 6.656 & 68.227 & 45 \\
\hline 2017 & 8.260 & 75.224 & 53 \\
\hline 2018 & 9.492 & 76.958 & 62 \\
\hline 2019 & 10.486 & 92.419 & 71 \\
\hline 2020 & 11.159 & & \\
\hline
\end{tabular}

\begin{tabular}{|r|r|r|r|r|}
\hline Realisatie 2017 & Realisatie 2018 & Realisatie 2019 & Realisatie 2020 & Realisatie 2021 \\
\hline $62.116 \mathrm{ha}$ & $69.989 \mathrm{ha}$ & $76.943 \mathrm{ha}$ & $83.968 \mathrm{ha}$ & $88.795 \mathrm{ha}$ \\
\hline
\end{tabular}

\begin{tabular}{lll}
\hline Fauna in agrarisch & Waarnemingen - index & $2015-58$ \\
gebied & trend $1990=100$ & $2016-47$ \\
& $2017-49$ \\
& $2018-42$
\end{tabular}

Percentage innoverende \%

bedrijven

\begin{tabular}{|l|r|r|r|r|}
\hline Referentiewaarde & Peildatum & Raming 2022 & Streefwaarde & Planning \\
\hline $7 \%$ & 2018 & $8 \%$ & $10 \%$ & 2025 \\
\hline $8 \%$ & 2019 & & $10 \%$ & 2025 \\
\hline
\end{tabular}

Aandeel technologische \%

landbouw goederen in

\begin{tabular}{|l|r|r|r|r|}
\hline Referentiewaarde & Peildatum & Raming 2022 & Streefwaarde & Planningstreefwaarde \\
\hline $9,3 \%$ & 2020 & $11 \%$ & $12 \%$ & 2021 \\
\hline
\end{tabular}

totale landbouwexport

\begin{tabular}{|l|r|r|r|r|}
\hline Referentiewaarde & Peildatum & Raming 2022 & Streefwaarde & Planning streefwaarde \\
\hline 0 & 2020 & 10.500 & 14.460 & 2023 \\
\hline
\end{tabular}

Aantal toegekende

vouchers voor

bedrijfsadviezen

Verhouding

duurzame/totale

investeringen

\begin{tabular}{|l|r|r|r|r|}
\hline Referentiewaarde & Peildatum & Raming 2022 & Streefwaarde & Planning streefwaarde \\
\hline $16 \%$ & 2018 & $25 \%$ & $30 \%$ & 2025 \\
\hline $17 \%$ & 2019 & & $30 \%$ & 2025 \\
\hline
\end{tabular}




\section{Bijlage 3 Definitie agribusiness}

Tabel B3.1 SBI's die vallen onder de agribusiness

\section{SBI Omschrijving}

01xx Landbouw, jacht en dienstverlening voor de landbouw en jacht

$03 x x \quad$ Visserij en kweken van vis en schaaldieren

$10 x x \quad$ Vervaardiging van voedingsmiddelen

$11 x x$ Vervaardiging van dranken

2015 Vervaardiging kunstmeststoffen en stikstofverbindingen

2020 Vervaardiging verdelgingsmiddelen en overige landbouwchemicaliën

2830 Vervaardiging van machines en werktuigen voor de land- en bosbouw

2893 Vervaardiging van machines voor de productie van voedings- en genotmiddelen

4611 Handelsbemiddeling in landbouwproducten, levende dieren en grondstoffen voor textiel en voedingsmiddelen

4617 Handelsbemiddeling in voedings- en genotmiddelen

46211 Groothandel in granen

46212 Groothandel in zaden, pootgoed en peulvruchten

46213 Groothandel in hooi, stro en ruwvoeder

46214 Groothandel in meng- en krachtvoeder

46215 Groothandel in veevoeder (geen ruw-, meng- en krachtvoeder)

46216 Groothandel in ruwe plantaardige en dierlijke oliën en vetten en oliehoudende grondstoffen

46218 Groothandel in akkerbouwproducten en veevoeder algemeen assortiment

46219 Groothandel in overige akkerbouwproducten

4622 Groothandel in bloemen en planten

46231 Groothandel in levend vee

46232 Groothandel in huisdieren, siervissen, siervogels en wilde dieren

46311 Groothandel in groenten en fruit

46312 Groothandel in consumptieaardappelen

4632 Groothandel in vlees en vleeswaren en in wild en gevogelte (niet levend)

46331 Groothandel in zuivelproducten en spijsoliën en -vetten

46332 Groothandel in eieren

4634 Groothandel in dranken (geen zuivel)

4636 Groothandel in suiker, chocolade en suikerwerk

4637 Groothandel in koffie, thee, cacao en specerijen (geen ruwe)

46381 Groothandel in snacks

46382 Groothandel in vis, schaal- en weekdieren

46383 Gespecialiseerde groothandel in overige voedings- en genotmiddelen (rest)

46384 Groothandel in bakkerijgrondstoffen

46389 Gespecialiseerde groothandel in overige grondstoffen en halffabricaten voor de voedingsmiddelenindustrie (rest)

4639 Groothandel in voedings- en genotmiddelen algemeen assortiment

4661 Groothandel in landbouwmachines, werktuigen en tractoren

46682 Groothandel in machines voor de voedings- en genotmiddelenindustrie

4711 Supermarkten en dergelijke winkels met een algemeen assortiment voedings- en genotmiddelen

4721 Winkels in aardappelen, groenten en fruit

47221 Winkels in vlees en vleeswaren

47222 Winkels in wild en gevogelte

4723 Winkels in vis

47241 Winkels in brood en banket

47242 Winkels in chocolade en suikerwerk

4725 Winkels in dranken

47291 Winkels in kaas

47292 Winkels in natuurvoeding en reformartikelen

47293 Winkels in buitenlandse voedingsmiddelen

47299 Gespecialiseerde winkels in overige voedings- en genotmiddelen (rest)

47811 Markthandel in aardappelen, groenten en fruit

47819 Markthandel in overige voedings- en genotmiddelen

47891 Markthandel in bloemen, planten, zaden en tuinbenodigdheden

71201 Keuring en controle van agrarische producten en voedingsmiddelen

72111 Biotechnologisch speur- en ontwikkelingswerk op het gebied van agrarische producten en processen

72191 Speur- en ontwikkelingswerk op het gebied van landbouw en visserij (niet biotechnologisch)

7731 Verhuur en lease van landbouwmachines en -werktuigen

82991 Veilingen van landbouw-, tuinbouw- en visserijproducten 
Wageningen Economic Research Postbus 29703

2502 LS Den Haag

T 0703358330

E communications.ssg@wur.nl wur.nl/economic-research

RAPPORT 2022-013
De missie van Wageningen University \& Research is 'To explore the potential of nature to improve the quality of life'. Binnen Wageningen University \& Research bundelen Wageningen University en gespecialiseerde onderzoeksinstituten van Stichting Wageningen Research hun krachten om bij te dragen aan de oplossing van belangrijke vragen in het domein van gezonde voeding en leefomgeving. Met ongeveer 30 vestigingen, 6.800 medewerkers ( $6.000 \mathrm{fte}$ ) en 12.900 studenten behoort Wageningen University \& Research wereldwijd tot de aansprekende kennisinstellingen binnen haar domein. De integrale benadering van de vraagstukken en de samenwerking tussen verschillende disciplines vormen het hart van de unieke Wageningen aanpak. 


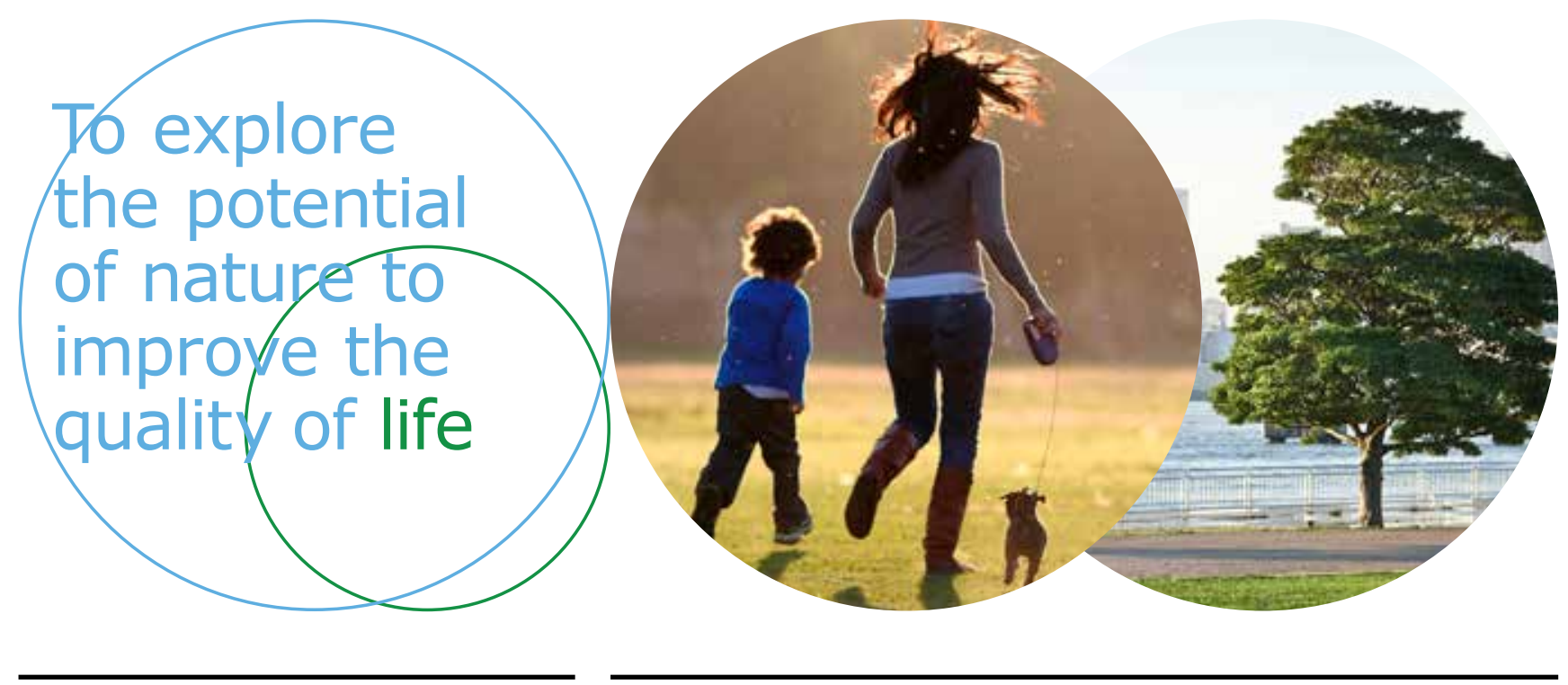

Wageningen Economic Research Postbus 29703

2502 LS Den Haag

T 0703358330

E communications.ssg@wur.nl wur.nl/economic-research

Rapport 2022-013

ISBN 978-94-6447-064-2
De missie van Wageningen University \& Research is 'To explore the potential of nature to improve the quality of life'. Binnen Wageningen University \& Research bundelen Wageningen University en gespecialiseerde onderzoeksinstituten van Stichting Wageningen Research hun krachten om bij te dragen aan de oplossing van belangrijke vragen in het domein van gezonde voeding en leefomgeving. Met ongeveer 30 vestigingen, 6.800 medewerkers ( $6.000 \mathrm{fte}$ ) en 12.900 studenten behoort Wageningen University \& Research wereldwijd tot de aansprekende kennisinstellingen binnen haar domein. De integrale benadering van de vraagstukken en de samenwerking tussen verschillende disciplines vormen het hart van de unieke Wageningen aanpak. 